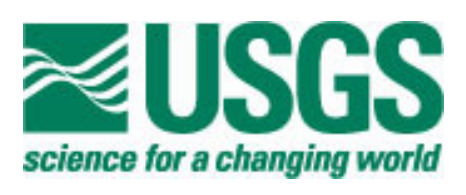

\title{
Detailed Geophysical Fault Characterization in Yucca Flat, Nevada Test Site, Nevada
}

By Theodore H. Asch, Donald Sweetkind, Bethany L. Burton, and Erin L. Wallin

Open-File Report 2008-1346

U.S. Department of the Interior

U.S. Geological Survey 


\title{
U.S. Department of the Interior \\ KEN SALAZAR, Secretary
}

\section{U.S. Geological Survey}

Suzette M. Kimball, Acting Director

\author{
U.S. Geological Survey, Reston, Virginia 2009
}

Prepared in cooperation with the U.S. Department of Energy, National Nuclear Security Administration Nevada Site Office under Interagency Agreement DEAl52-07NV28100

For product and ordering information:

World Wide Web: http://www.usgs.gov/pubprod

Telephone: 1-888-ASK-USGS

For more information on the USGS - the Federal source for science about the Earth, its natural and living resources, natural hazards, and the environment:

World Wide Web: http://www.usgs.gov

Telephone: 1-888-ASK-USGS

Suggested citation:

Asch, T.H., Sweetkind, D., Burton, B.L., and Wallin, E.L., 2009, Detailed geophysical fault characterization in Yucca Flat, Nevada Test Site, Nevada: U.S. Geological Survey Open-File Report 2008-1346, 64 p., plus two appendixes.

Any use of trade, product, or firm names is for descriptive purposes only and does not imply endorsement by the U.S. Government. This publication has not been reviewed for stratigraphic nomenclature.

This publication has not been reviewed for stratigraphic nomenclature.

Although this report is in the public domain, permission must be secured from the individual copyright owners to reproduce any copyrighted material contained within this report. 


\section{Contents}

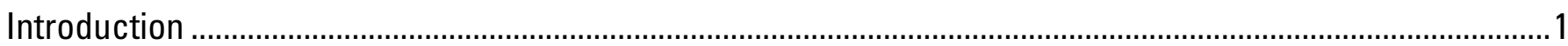

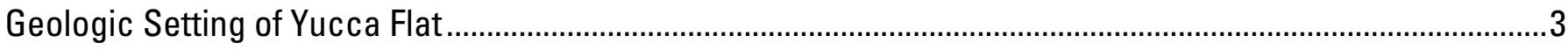

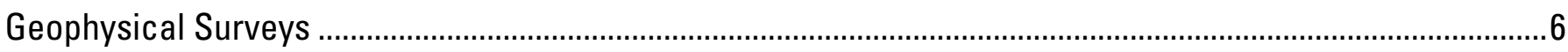

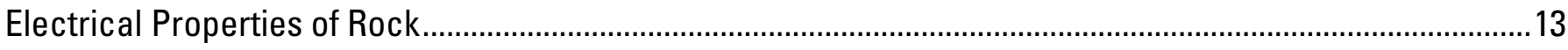

DC Resistivity Investigation ....................................................................................................................... 14

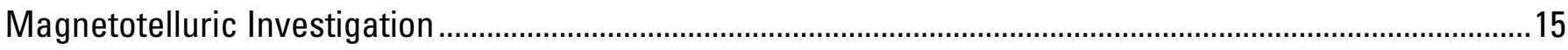

Yucca Flat Magnetotelluric Investigation ............................................................................................. 18

Vertical Gradient Magnetic Field Investigation .......................................................................................... 18

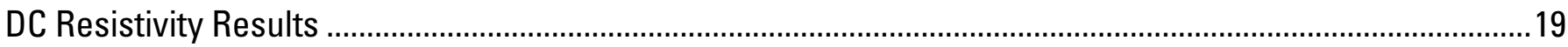

2005 Field Effort — Lines YFRESEW and YFRESNS ……….................................................................... 19

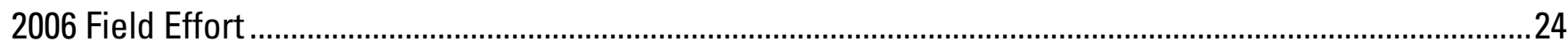

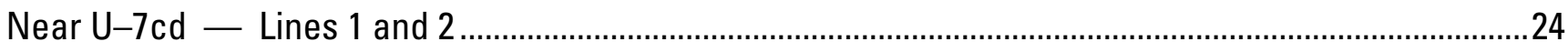

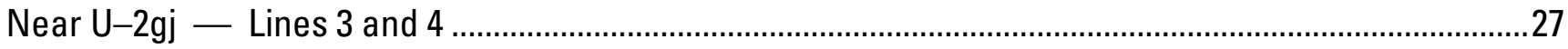

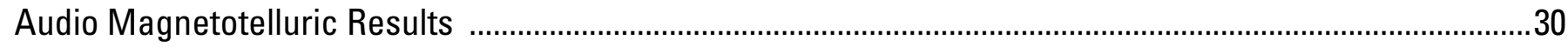

Two-dimensional Modeling Analysis of the AMT Data.................................................................................

2005 Field Effort — Lines YFRESEW and YFRESNS ……….....................................................................

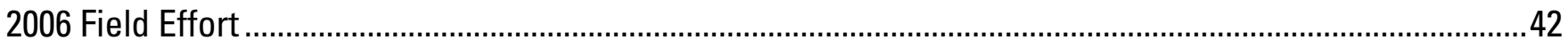

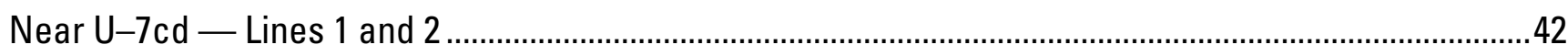

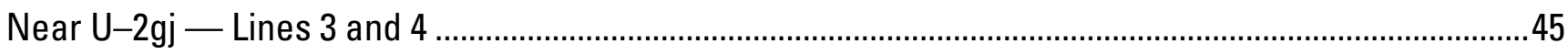

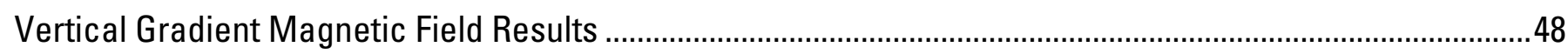

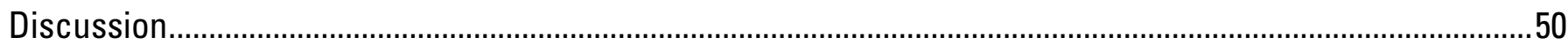


Geophysical Response Related to Varying Fault Offset

Geophysical Response Related to Fault-Zone Geometry and Architecture. 51

Conclusions .58

References Cited .59

\section{Appendixes}
A. DC Resistivity Two-Dimensional Modeling
B. AMT Data

\section{Figures}

1. Geophysical study locations at drill holes U-7cd and U-2gj in Yucca Flat 4

2. Geophysical study locations on photo mosaic of northern Yucca Flat basin. 17

3. Yucca Flat DC resistivity two-dimensional inversion modeling results for line YFRESEW .22

4. Yucca Flat DC resistivity two-dimensional inversion modeling results for line YFRESNS. 23

5. DC resistivity two-dimensional inversion modeling results for Line 1 of 2006 field effort 25

6. DC resistivity two-dimensional inversion modeling results for Line 2 of 2006 field effort 26

7. DC resistivity two-dimensional inversion modeling results for Line 3 of 2006 field effort .28

8. DC resistivity two-dimensional inversion modeling results for Line 4 of 2006 field effort 29

9. Two-dimensional AMT inversion modeling results for the TM mode along line YFRESEW. 37

10. Two-dimensional MT inversion modeling results from regional Yucca Flat deep resistivity study 38

11. AMT two-dimensional inversion modeling results for the TM mode along Line YFRESNS .40

12. Two-dimensional AMT inversion modeling results for the TE mode along line YFRESEW 41

13. AMT two-dimensional inversion modeling results for Line 1 of 2006 field effort 43 
14. AMT two-dimensional inversion modeling results for Line 2 of 2006 field effort 44

15. AMT two-dimensional inversion modeling results for Line 3 of 2006 field effort .46

16. AMT two-dimensional inversion modeling results for Line 4 of 2006 field effort 47

17. Bottom sensor total magnetic field data along lines YFRESEW and YFRESNS. 49

18. Map of the Yucca fault and surface effects near drill hole U-7cd .53

19. Three-dimensional perspective view of AMT profiles, Yucca fault and surface effects near drill hole U-7cd.

20. Three-dimensional perspective view of DC resistivity profiles, Yucca fault, and surface effects. near drill hole $\mathrm{U}-7 \mathrm{~cd}$ .56

21. Three-dimensional perspective view of $D C$ resistivity profiles and surface effects near drill hole U-2gj.

\section{Tables}

1. Location of drill holes U-7cd and U-2gj...... 6

2. Coordinates of 2005 Line YFRESEW 7

3. Coordinates of 2005 Line YFRESNS .8

4. Coordinates of 2006 Line 1 9

5. Coordinates of 2006 Line 2 10

6. Coordinates of 2006 Line 3 11

7. Coordinates of 2006 Line 4 12

8. DC resistivity two-dimensional inversion parameters 20

9. AMT profile azimuths and angles of rotation applied during processing......... 30

10. AMT two-dimensional Inversion and Forward modeling mesh parameters .35 


\section{Conversion Factors}

\begin{tabular}{lcl}
\hline \multicolumn{1}{c}{ Multiply } & By & \multicolumn{1}{c}{ To obtain } \\
inch (in.) & 2.54 & centimeter (cm) \\
inch (in.) & 25.4 & millimeter (mm) \\
foot (ft) & 0.3048 & meter (m) \\
mile (mi) & 1.609 & kilometer (km) \\
centimeter (cm) & 0.3937 & inch (in.) \\
millimeter (mm) & 0.03937 & inch (in.) \\
meter (m) & 3.281 & foot (ft) \\
kilometer (km) & 0.6214 & mile (mi)
\end{tabular}

Vertical coordinate information is referenced to the North American Vertical Datum of 1988 (NAVD88).

Horizontal coordinate information is referenced to either the North American Datum of 1927 (NAD 27) or 1983 (NAD83).

Elevation, as used in this report, refers to distance above the vertical datum. 


\section{Detailed Geophysical Fault Characterization in}

\section{Yucca Flat, Nevada Test Site, Nevada}

By Theodore H. Asch, Donald Sweetkind, Bethany L. Burton, and Erin L. Wallin

\section{Introduction}

Yucca Flat is a topographic and structural basin in the northeastern part of the Nevada Test Site (NTS) in Nye County, Nevada (fig. 1). Between the years 1951 and 1992, 659 underground nuclear tests took place in Yucca Flat (U.S. Department of Energy, 2000); most were conducted in large, vertical excavations that penetrated alluvium and the underlying Cenozoic volcanic rocks (U.S. Department of Energy, 2000).

Radioactive and other potential chemical contaminants at the NTS are the subject of a long-term program of investigation and remediation by the U.S. Department of Energy (DOE), National Nuclear Security Administration, Nevada Site Office, under its Environmental Restoration Program. As part of the program, the DOE seeks to assess the extent of contamination and to evaluate the potential risks to humans and the environment from byproducts of weapons testing (Department of Energy, 2003). To accomplish this objective, the DOE Environmental Restoration Program is constructing and calibrating a ground-water flow model to predict hydrologic flow in Yucca Flat as part of an effort to quantify the subsurface hydrology of the Nevada Test Site. A necessary part of calibrating and evaluating a model of the flow system is an understanding of the location and characteristics of faults that may influence 
ground-water flow. Such influence may include fault offset that results in the juxtaposition of stratigraphic units with contrasting hydrologic properties (or special physical characteristics of the fault zones) such as brecciation and fracturing, that may cause specific parts of the zone to act either as conduits or as barriers to fluid flow. In addition, knowledge of fault-zone architecture and physical properties is a fundamental component of the containment of the contamination from underground nuclear tests (Carothers, 1995), should such testing ever resume at the Nevada Test Site.

The goal of the present investigation is to develop a detailed understanding of the geometry and physical properties of fault zones in Yucca Flat. Such an understanding is essential in assessing the role of faults in the near-field ground-water flow environment and their importance in designing a successful containment strategy in Yucca Flat. Previous surface geologic mapping (Slate and others, 1999), geophysical studies, and data from hundreds of drill holes in Yucca Flat have defined the location and magnitude of offset of faults in the basin. A number of previous geophysical investigations using gravity data have defined the principal subsurface breaks within Paleozoic bedrock (Ferguson and others, 1988; Phelps and others, 1999; Phelps and McKee, 1999); abundant drill-hole data (Covington and Berger, 1997) allow definition of the magnitude of offset across the faults in the Cenozoic units and changes in offset magnitude along fault strike. Geologic and geophysical data from Yucca Flat have previously been integrated to produce a three-dimensional framework model that incorporates fault location, dip and offset (Bechtel Nevada, 2006).

The present study was designed to investigate faults in greater detail and to characterize fault geometry, the presence of fault splays, and the fault-zone width. Integrated, recent geological and geophysical studies have been designed and implemented to work toward this goal. 
This report describes, in detail, the geophysical surveys conducted near two drill holes in Yucca Flat, the data analyses performed, and the integrated interpretations developed from the suite of geophysical methodologies utilized in this investigation. Data collection for this activity started in the spring of 2005 and continued into 2006. A suite of electrical geophysical surveys was run in combination with ground magnetic surveys; these surveys resulted in high-resolution subsurface data that portray subsurface fault geometry at the two sites and have identified structures not readily apparent from surface geologic mapping, potential field geophysical data, or surface-effects fracture maps.

\section{Geologic Setting of Yucca Flat}

Yucca Flat is an elongate alluvial basin of Cenozoic age that formed consequent to regional crustal extension that was oriented generally east-west (Cole and others, 1997). Rocks exposed around the margins of the basin, and known in the subsurface from drill-hole data, include sedimentary rocks of Late Proterozoic to Mississippian age, local intrusive rocks of Mesozoic age, and volcanic and tuffaceous sedimentary rocks of Cenozoic age (fig. 1). The preCenozoic section includes Late Proterozoic through Lower Cambrian, predominantly siliciclastic rocks, a 4,500-m-thick Middle Cambrian through Middle Devonian carbonate-dominated succession, a 1,000- to 2,000-m-thick section of Upper Devonian through Mississippian shale, sandstone and minor limestone, and local Pennsylvanian and Lower Permian carbonate rocks (Ekren, 1968; Winograd and Thordarson, 1975). The Cenozoic rocks in Yucca Flat consist of a thick alluvial section underlain by Miocene volcanic rocks and rare, thin, prevolcanic sedimentary rocks. The Miocene volcanic rocks that form the lower part of the basin fill were erupted from source areas in the nearby southwestern Nevada volcanic field (Byers and others, 1976; Sawyer and others, 1994). 

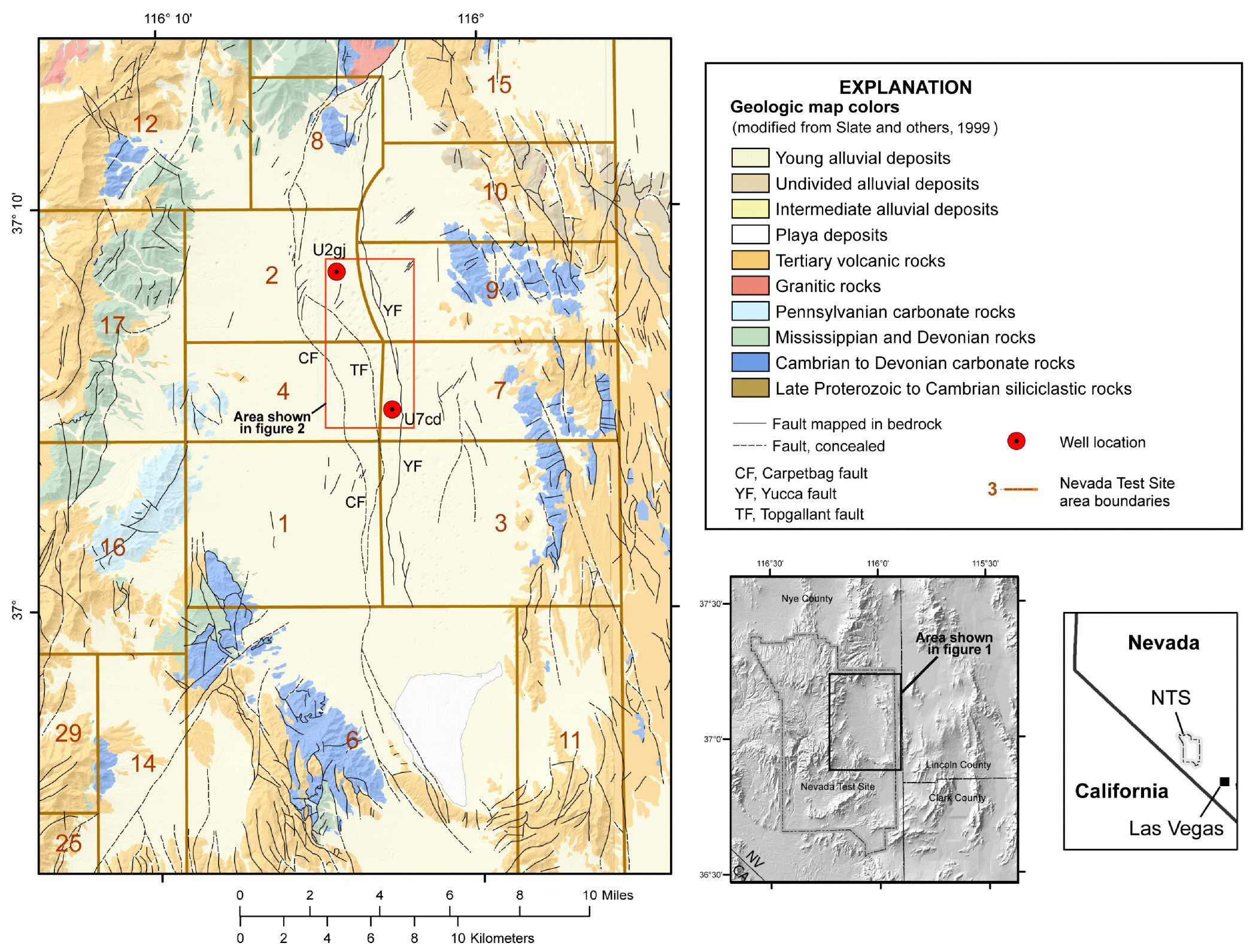

Figure 1. Geologic map of Yucca Flat showing drill-hole locations where geophysical studies were conducted. 
The volcanic rocks include variably welded ash-flow tuff, ash-fall tuff, and reworked tuff; the thickness and extent of these rocks vary greatly within the basin. The largely postvolcanic sedimentary basin fill consists of a mixture of loosely consolidated, coarse-grained alluvial and colluvial deposits that were derived from the surrounding Cenozoic silicic volcanic and Paleozoic siliciclastic and carbonate sedimentary rocks, fine-grained basin axis and playa deposits, and localized eolian sand and rare basalt flows (Byers and others, 1976; Sawyer and others, 1994).

The pre-Cenozoic sedimentary rocks show evidence of contractile deformation related to generally east- and southeast-directing thrusting during Mesozoic time (Caskey and Schweickert, 1992; Cole and Cashman, 1999). During late Cenozoic time, these rocks and the Cenozoic basin fill were affected by east-west extension that resulted in the formation of predominantly northstriking normal faults (Hinrichs, 1968). The Cenozoic volcanic units have been tilted west and have offset hundreds of meters by the major normal faults within the basin, including the Carpetbag, Topgallant, and Yucca faults (fig. 1); numerous faults with lesser offset exist as well (Hinrichs, 1968). Gravity models of the Yucca Flat basin define a Tertiary-Quaternary basin as much as 2,500 $\mathrm{m}$ deep to the east of the Carpetbag and Yucca faults, a midbasin high to the west of the Carpetbag fault, and a shallower basin to the west of the gravity high (Ferguson and others, 1988; Phelps and others, 1999). Movement along the Yucca fault in central Yucca Flat indicates deformation in the area has continued into the Holocene (Swadley and Hoover, 1990). 


\section{Geophysical Surveys}

In the spring of 2005 and 2006 the U.S. Geological Survey conducted geophysical investigations in the vicinity of two drill holes in Yucca Flat: U-7cd and U-2gj (table 1, fig. 2). These two sites were selected for their ease of access for the purposes of geophysical data collection, proximity to known or suspected faults, proximity to regional magnetotelluric (MT) survey sites (Asch and others, 2006), and the potential utility of the results from these sites to the government cooperator agencies. Drill hole U-7cd is in the immediate footwall of the Yucca fault (fig. 1), an east-dipping, east-side-down normal fault with 200 to $400 \mathrm{~m}$ of offset and a prominent easily observed topographic surface scarp.

Table 1. Location of drill holes U-7cd and U-2gj.

\begin{tabular}{crcrl}
\hline Well name & Latitude NAD 27 & Longitude NAD 27 & $\begin{array}{r}\text { NTS } \\
\text { area }\end{array}$ & Comment \\
\hline Station 1 & $37^{\circ} 04^{\prime} 51^{\prime \prime}$ & $116^{\circ} 02^{\prime} 44^{\prime \prime}$ & 7 & Emplacement well U-7cd. \\
Station 2 & $37^{\circ} 08^{\prime} 16^{\prime \prime}$ & $116^{\circ} 04^{\prime} 25^{\prime \prime}$ & 2 & Emplacement well U-2gj. \\
\hline
\end{tabular}

The initial fault investigation work in 2005 was for reconnaissance. One long traverse (table 2) was located so that it would possibly cross a couple of large faults, and a shorter traverse (table 3) was set perpendicular to the first to check for major lateral inhomogeneities. Line YFRESEW (fig. 2) is oriented approximately east-west (azimuth of 95 degrees), roughly perpendicular to the surface trace of the Yucca fault. The line is approximately $1,500 \mathrm{~m}$ in length, passes over the U-7cd pad and crosses the surface expression of Yucca fault on its eastern end (fig. 2). Line YFRESNS (fig. 2) is oriented approximately north-south, roughly parallel to the surface trace of the Yucca fault. The line is $500 \mathrm{~m}$ in length and is located about $200 \mathrm{~m}$ west of well U-7cd (fig. 2). 
Table 2. Line YFRESEW, acquired in 2005. Coordinates are in NAD83, Universal Transverse Mercator Zone $11 \mathrm{~N}$, meters. All data are OPUS-corrected.

\begin{tabular}{|c|c|c|c|}
\hline \multicolumn{4}{|c|}{ Line YFRESEW - West end } \\
\hline 0 & 583872.81 & 4104401.44 & $1,256.32$ \\
\hline 25 & 583897.50 & 4104398.98 & $1,255.94$ \\
\hline 50 & 583922.35 & 4104396.65 & $1,255.89$ \\
\hline 75 & 583947.29 & 4104394.40 & $1,255.65$ \\
\hline 100 & 583972.09 & 4104391.70 & $1,255.42$ \\
\hline 125 & 583996.80 & 4104389.39 & $1,255.33$ \\
\hline 150 & 584021.68 & 4104386.70 & $1,255.02$ \\
\hline 175 & 584046.50 & 4104383.98 & $1,254.77$ \\
\hline 200 & 584071.21 & 4104380.90 & $1,254.84$ \\
\hline 225 & 584095.97 & 4104378.51 & $1,254.28$ \\
\hline 250 & 584120.66 & 4104375.88 & $1,253.75$ \\
\hline 275 & 584145.43 & 4104373.29 & $1,253.25$ \\
\hline 300 & 584170.17 & 4104370.41 & $1,253.29$ \\
\hline 325 & 584194.94 & 4104368.06 & $1,253.15$ \\
\hline 350 & 584219.67 & 4104365.63 & $1,253.03$ \\
\hline 375 & 584244.55 & 4104362.82 & $1,252.96$ \\
\hline 400 & 584269.12 & 4104359.94 & $1,252.82$ \\
\hline 425 & 584293.83 & 4104357.20 & $1,252.79$ \\
\hline 450 & 584318.58 & 4104354.19 & $1,252.81$ \\
\hline 475 & 584343.61 & 4104351.94 & $1,252.50$ \\
\hline 500 & 584368.35 & 4104349.31 & $1,252.33$ \\
\hline 525 & 584392.71 & 4104345.97 & $1,252.31$ \\
\hline 550 & 584417.79 & 4104343.16 & $1,252.36$ \\
\hline 575 & 584442.53 & 4104340.22 & $1,252.25$ \\
\hline 600 & 584467.37 & 4104337.65 & $1,252.22$ \\
\hline 625 & 584491.94 & 4104334.35 & $1,252.12$ \\
\hline 650 & 584516.92 & 4104331.91 & $1,252.05$ \\
\hline 675 & 584541.79 & 4104329.04 & $1,251.77$ \\
\hline 700 & 584566.46 & 4104327.01 & $1,251.82$ \\
\hline 725 & 584591.38 & 4104324.13 & $1,251.40$ \\
\hline 735 & 584601.29 & 4104323.02 & $1,251.80$ \\
\hline 750 & 584616.13 & 4104321.28 & $1,251.41$ \\
\hline 775 & 584640.88 & 4104318.95 & $1,251.87$ \\
\hline 800 & 584665.57 & 4104316.13 & $1,252.67$ \\
\hline 825 & 584690.19 & 4104312.68 & $1,253.39$ \\
\hline 850 & 584715.02 & 4104309.72 & $1,254.19$ \\
\hline 875 & 584739.75 & 4104306.70 & $1,254.61$ \\
\hline 900 & 584764.61 & 4104304.54 & $1,254.91$ \\
\hline 925 & 584789.40 & 4104302.55 & $1,255.23$ \\
\hline 950 & 584814.20 & 4104299.88 & $1,255.31$ \\
\hline 975 & 584839.12 & 4104297.21 & $1,255.25$ \\
\hline 1,000 & 584863.68 & 4104294.77 & $1,255.13$ \\
\hline 1,025 & 584888.59 & 4104292.89 & $1,255.01$ \\
\hline 1,050 & 584913.51 & 4104291.10 & $1,254.89$ \\
\hline
\end{tabular}


Table 2, Line YYRESNS-West End.-Continued

\begin{tabular}{cccc}
\hline & Easting & Northing & Elevation \\
\hline 1,075 & 584938.39 & 4104289.42 & $1,254.57$ \\
1,100 & 584962.96 & 4104287.72 & $1,253.58$ \\
1,125 & 584987.80 & 4104285.75 & $1,252.69$ \\
1,150 & 585012.14 & 4104284.60 & $1,252.12$ \\
1,175 & 585037.67 & 4104283.07 & $1,252.53$ \\
1,200 & 585062.44 & 4104281.71 & $1,252.22$ \\
1,225 & 585087.42 & 4104280.15 & $1,252.89$ \\
1,250 & 585112.19 & 4104278.86 & $1,252.74$ \\
1,275 & 585137.09 & 4104277.02 & $1,253.15$ \\
1,300 & 585161.89 & 4104275.29 & $1,253.29$ \\
1,325 & 585186.76 & 4104273.34 & $1,252.59$ \\
1,350 & 585211.58 & 4104271.71 & $1,250.55$ \\
1,375 & 585236.23 & 4104269.82 & $1,249.73$ \\
1,400 & 585261.19 & 4104267.29 & $1,247.78$ \\
1,425 & 585285.78 & 4104265.48 & $1,247.40$ \\
1,450 & 585310.69 & 4104263.40 & $1,246.92$ \\
1,475 & 585335.55 & 4104261.30 & $1,247.06$ \\
1,500 & 585360.37 & 4104259.01 & $1,247.26$ \\
Line YFRESEW - East end & & \\
\hline
\end{tabular}

Table 3. Line YFRESNS, acquired in 2005. Coordinates are in NAD83, UTM Zone 11N, meters. All data are OPUS-corrected.

\begin{tabular}{rrcc}
\hline Line YFRESNS $-\begin{array}{c}\text { North end } \\
\text { Easting }\end{array}$ & Northing & Elevation \\
\hline 0 & 584555.77 & 4104576.88 & $1,253.52$ \\
25 & 584555.85 & 4104551.96 & $1,252.92$ \\
50 & 584555.50 & 4104527.34 & $1,252.44$ \\
75 & 584556.05 & 4104502.16 & $1,252.81$ \\
100 & 584556.23 & 4104477.10 & $1,252.87$ \\
125 & 584556.34 & 4104452.20 & $1,252.72$ \\
150 & 584556.10 & 4104427.42 & $1,252.59$ \\
175 & 584556.37 & 4104402.32 & $1,252.29$ \\
200 & 584556.53 & 4104377.43 & $1,252.24$ \\
225 & 584556.45 & 4104352.37 & $1,251.99$ \\
250 & 584556.61 & 4104327.58 & $1,251.58$ \\
275 & 584556.72 & 4104302.95 & $1,251.51$ \\
300 & 584556.96 & 4104278.07 & $1,251.20$ \\
325 & 584557.16 & 4104253.15 & $1,250.98$ \\
350 & 584557.33 & 4104228.21 & $1,250.81$ \\
375 & 584557.40 & 4104203.33 & $1,250.61$ \\
400 & 584557.50 & 4104178.07 & $1,250.28$ \\
425 & 584557.56 & 4104153.44 & $1,250.29$ \\
450 & 584557.69 & 4104128.21 & $1,250.03$ \\
475 & 584557.80 & 4104103.56 & $1,249.86$ \\
500 & 584558.01 & 4104078.51 & $1,249.73$ \\
Line YFRESNS - South end & & \\
\hline
\end{tabular}


The 2006 DC and AMT surveys were designed to examine, in greater detail, the subsurface geology of known fault zones in the vicinity of the two drill holes by using DC resistivity and AMT measurements. Near U-7cd, the Yucca fault escarpment, which was crossed in 2005 by line YFRESEW on its eastern terminus, was selected for investigation at a higher resolution. A pair of survey traverses (Lines 1 [240 m, table 4] and 2 [200 m, table 5], fig. 2) were approximately centered on Yucca fault in this area. The lines were separated by about 200 $\mathrm{m}$, and Line 2 is located north of Line 1.

Table 4. Line 1, acquired in 2006. Coordinates are in North American Datum (NAD83), Universal Transverse Mercator Zone 11North, meters. All data are OPUS-corrected.

\begin{tabular}{|c|c|c|c|}
\hline Line 1 - West end & Easting & Northing & Elevation \\
\hline 1000 & 585105.60 & 4104275.73 & $1,248.28$ \\
\hline 1010 & 585115.47 & 4104275.14 & $1,252.58$ \\
\hline 1020 & 585125.44 & 4104274.67 & $1,252.69$ \\
\hline 1030 & 585135.39 & 4104273.98 & $1,252.80$ \\
\hline 1040 & 585145.35 & 4104273.53 & $1,252.98$ \\
\hline 1050 & 585155.34 & 4104273.41 & $1,253.27$ \\
\hline 1060 & 585165.30 & 4104272.87 & $1,253.27$ \\
\hline 1070 & 585175.28 & 4104272.38 & $1,252.97$ \\
\hline 1080 & 585185.22 & 4104272.06 & $1,252.69$ \\
\hline 1090 & 585195.36 & 4104272.07 & $1,252.39$ \\
\hline 1092 & 585197.08 & 4104272.03 & $1,252.28$ \\
\hline 1098 & 585203.08 & 4104271.86 & $1,251.11$ \\
\hline 1100 & 585204.87 & 4104271.91 & $1,250.83$ \\
\hline 1110 & 585214.64 & 4104271.26 & $1,250.43$ \\
\hline 1120 & 585224.82 & 4104270.89 & $1,250.18$ \\
\hline 1130 & 585234.70 & 4104270.51 & $1,249.79$ \\
\hline 1140 & 585244.46 & 4104270.32 & $1,248.90$ \\
\hline 1150 & 585254.55 & 4104269.91 & $1,248.24$ \\
\hline 1160 & 585264.32 & 4104269.28 & $1,247.73$ \\
\hline 1170 & 585274.56 & 4104268.85 & $1,247.62$ \\
\hline 1180 & 585284.46 & 4104268.47 & $1,247.54$ \\
\hline 1190 & 585294.41 & 4104268.11 & $1,247.48$ \\
\hline 1200 & 585304.29 & 4104267.93 & $1,247.25$ \\
\hline 1210 & 585314.19 & 4104267.15 & $1,246.78$ \\
\hline 1220 & 585324.13 & 4104266.52 & $1,246.90$ \\
\hline 1230 & 585334.10 & 4104266.28 & $1,247.04$ \\
\hline 1238 & 585342.23 & 4104266.17 & $1,247.21$ \\
\hline Line 1 - East end & & & \\
\hline
\end{tabular}


Table 5. Line 2, acquired in 2006. Coordinates are in North American Datum (NAD83), Universal Transverse Mercator Zone 11North, meters. All data are OPUS-corrected.

\begin{tabular}{rccc}
\hline Line 2 - West end & Easting & Northing & Elevation \\
\hline 2000 & 585071.71 & 4104451.11 & $1,254.73$ \\
2010 & 585081.54 & 4104452.79 & $1,254.79$ \\
2020 & 585091.45 & 4104454.42 & $1,254.96$ \\
2030 & 585101.48 & 4104455.83 & $1,255.53$ \\
2040 & 585111.11 & 4104457.39 & $1,254.69$ \\
2050 & 585120.95 & 4104459.21 & $1,254.80$ \\
2060 & 585130.80 & 4104460.57 & $1,254.48$ \\
2070 & 585140.64 & 4104462.17 & $1,254.02$ \\
2080 & 585150.51 & 4104463.36 & $1,253.62$ \\
2090 & 585160.30 & 4104465.12 & $1,253.12$ \\
2100 & 585170.01 & 4104466.74 & $1,251.32$ \\
2110 & 585179.76 & 4104467.72 & $1,251.07$ \\
2120 & 585189.61 & 4104469.19 & $1,250.90$ \\
2130 & 585199.49 & 4104470.48 & $1,250.99$ \\
2140 & 585209.37 & 4104472.05 & $1,250.74$ \\
2150 & 585219.21 & 4104473.68 & $1,250.37$ \\
2160 & 585229.15 & 4104474.91 & $1,249.75$ \\
2170 & 585238.92 & 4104476.78 & $1,249.38$ \\
2180 & 585248.72 & 4104478.49 & $1,249.31$ \\
2190 & 585258.59 & 4104480.11 & $1,249.02$ \\
2200 & 585268.43 & 4104481.60 & $1,248.71$ \\
\hline Line 2 - East end & & & \\
\hline & & & \\
\hline
\end{tabular}

The second area investigated in 2006 centers around drill hole U-2gj. Asch and others (2006), using regional magnetotelluric measurements, reported that the structural geology in the vicinity of drill-hole U-2gj (stations 39 and 40, Asch and others, 2006) was complicated by a network of small faults. The 2006 data collection effort was designed to provide more detailed information on the nature of the faults in that area. Line 3 (200 m, table 6) was located so that it passed near regional MT station 39 of the Asch and others (2006) study. Both Lines 3 and 4 (each $200 \mathrm{~m}$ long; see table 7) were located so that they would cross a known small fault (Slate and others, 1999) in the vicinity of the well pad of U-2gj. 
The observed and calculated results for the DC resistivity modeling are included in Appendix A, and the observed and calculated data for the AMT modeling are included in Appendix B.

Table 6. Line 3, acquired in 2006. Coordinates are in North American Datum (NAD83), Universal Transverse Mercator Zone 11North, meters. All data are OPUS-corrected.

\begin{tabular}{cccc}
\hline \multicolumn{2}{c}{ Line 3 - Northwest end } & Northing & Elevation \\
\hline 3000 & 582180.24 & 4109659.78 & $1,302.61$ \\
3010 & 582189.03 & 4109655.44 & $1,302.47$ \\
3020 & 582198.20 & 4109651.27 & $1,302.35$ \\
3030 & 582207.27 & 4109647.15 & $1,302.20$ \\
3040 & 582216.12 & 4109643.01 & $1,302.13$ \\
3050 & 582225.35 & 4109638.57 & $1,301.89$ \\
3060 & 582234.58 & 4109634.63 & $1,301.68$ \\
3070 & 582243.51 & 4109630.50 & $1,301.59$ \\
3080 & 582252.80 & 4109626.49 & $1,301.39$ \\
3090 & 582261.92 & 4109622.42 & $1,301.20$ \\
3100 & 582271.09 & 4109618.48 & $1,300.83$ \\
3110 & 582280.00 & 4109614.19 & $1,300.75$ \\
3120 & 582288.98 & 4109609.92 & $1,300.57$ \\
3130 & 582298.00 & 4109605.69 & $1,300.37$ \\
3140 & 582307.10 & 4109601.55 & $1,300.10$ \\
3150 & 582316.11 & 4109597.26 & $1,299.95$ \\
3160 & 582325.17 & 4109593.01 & $1,300.00$ \\
3170 & 582334.15 & 4109588.84 & $1,299.98$ \\
3180 & 582343.27 & 4109584.52 & $1,299.87$ \\
3190 & 582352.37 & 4109580.28 & $1,299.69$ \\
3200 & 582361.39 & 4109576.17 & $1,299.43$ \\
\hline Line 3 - Southeast end & & \\
\hline
\end{tabular}

Although the Yucca Flat fault is generally north-striking, it is distinctly sinuous in detail, probably as a result of en-echelon linked segments. Geophysical traverses were designed to cross the trace of the fault, evaluate the extent of footwall damage, and investigate possible hanging wall splay faults. Farther to the north, drill hole $U-2 g j$ is roughly equidistant $(2 \mathrm{~km})$ from the Yucca fault and the Carpetbag/Topgallant fault system (fig. 1). Surficial geologic mapping (Slate and others, 1999) and analysis of surface effects (Grasso, 2001) suggest the presence of small- 
offset faults. Geophysical surveys at this location were designed to investigate minor faults distant from the major mapped normal faults in the basin.

Table 7. Line 4, acquired in 2006. Coordinates are in North American Datum (NAD83), Universal Transverse Mercator Zone 11North, meters. All data are OPUS-corrected.

\begin{tabular}{rccc}
\hline Line 4 - West end & Easting & Northing & Elevation \\
\hline 4000 & 582323.42 & 4110702.61 & $1,312.28$ \\
4010 & 582333.31 & 4110701.77 & $1,312.25$ \\
4020 & 582343.23 & 4110700.93 & $1,312.15$ \\
4030 & 582353.17 & 4110700.18 & $1,312.09$ \\
4040 & 582363.15 & 4110699.69 & $1,312.04$ \\
4050 & 582372.86 & 4110698.80 & $1,311.26$ \\
4060 & 582382.98 & 4110698.03 & $1,311.66$ \\
4070 & 582392.94 & 4110697.34 & $1,311.64$ \\
4080 & 582402.94 & 4110696.68 & $1,311.60$ \\
4090 & 582412.87 & 4110696.02 & $1,311.39$ \\
4100 & 582422.82 & 4110695.29 & $1,311.39$ \\
4110 & 582432.80 & 4110694.83 & $1,311.36$ \\
4120 & 582442.73 & 4110694.06 & $1,311.48$ \\
4130 & 582452.69 & 4110693.26 & $1,311.46$ \\
4140 & 582462.63 & 4110692.41 & $1,311.42$ \\
4150 & 582472.60 & 4110691.54 & $1,311.37$ \\
4160 & 582482.49 & 4110690.81 & $1,311.33$ \\
4170 & 582492.53 & 4110689.94 & $1,310.67$ \\
4180 & 582502.52 & 4110689.36 & $1,310.53$ \\
4190 & 582512.28 & 4110688.66 & $1,310.41$ \\
4200 & 582522.27 & 4110687.57 & $1,310.34$ \\
\hline
\end{tabular}

The geophysical studies described in this report collected 6-channel 3-D tensor audiomagnetotelluric (AMT) data, shallow DC resistivity data, and total magnetic field and vertical gradient magnetic field data near drill-hole U-7cd only. DC resistivity would provide enhanced near-surface resolution (2-m to 90-m depth). The AMT data would complement the DC resistivity data in the near-surface and then provide greater resolution vertically down to approximately 600-m to 800-m depth (depending on how conductive or resistive the subsurface materials are and on the quality of the data). The surveys were located such that the data could then be compared with the results of a previous regional MT study that had resolution to almost 
$10 \mathrm{~km}$ (Asch and others, 2006). A Leica 1200 Global Positioning System (GPS) was used to locate all data-measurement stations in this investigation.

\section{Electrical Rock Properties}

Electromagnetic geophysical methods detect variations in the electrical properties of rocks — in particular, electrical resistivity, or its inverse, electrical conductivity. Electrical resistivity can be correlated with geologic units on the surface and at depth using lithologic logs to provide a three-dimensional (3-D) picture of subsurface geology. In the upper crust, the resistivities of geologic units are largely dependent upon their fluid content, pore-volume porosity, interconnected fracture porosity, and conductive mineral content (Keller, 1989). While there is not a one-to-one relationship between lithology and resistivity, there are general correlations that can be made using typical values, even though values can be found at other localities that may fall outside of the ranges presented herein (Palacky, 1987). Fluids within the pore spaces and fracture openings, especially if saline, can reduce electrical resistivities in what would otherwise be a resistive rock matrix. Resistivity can also be lowered by the presence of electrically conductive clay minerals, graphitic carbon, and metallic mineralization. It is common, for example, for altered volcanic rocks to contain replacement minerals that have resistivities 10 times lower than those of the surrounding rocks (Nelson and Anderson, 1992). Fine-grained sediments, such as clay-rich alluvium, marine shales, and other mudstones, are normally conductive from a few ohm-meters to a few tens of ohm-meters (Keller, 1987; Palacky, 1987). Metamorphic rocks (nongraphitic) and unaltered, unfractured igneous rocks are normally moderately to highly resistive (a few hundreds to thousands of ohm-meters). Carbonate rocks can have similarly high resistivities depending on their fluid content, porosity, and impurities (Keller, 1987; Palacky, 1987). Fault zones may be moderately conductive (tens of ohm-meters) when 
composed of rocks fractured enough to have hosted fluid transport and consequent mineralogical alteration (Eberhart-Phillips and others, 1995). Higher subsurface temperatures cause higher ionic mobility that reduces rock resistivities (Keller, 1987; Palacky, 1987). Tables of electrical resistivity for a variety of rocks, minerals, and geological environments are in Keller (1987) and Palacky (1987).

\section{Resistivity Investigation}

The DC resistivity data were collected using the Advanced Geosciences Inc. (AGI). SuperSting R8 system (Advanced Geosciences, Inc., 2003). The SuperSting is an 8-channel multielectrode resistivity and IP imaging system. The R8 reads eight potential differences for each 200-W current injection using 24-V batteries. A multichannel Swift dual-mode automatic multielectrode cable with outtakes to stainless-steel electrodes brings the data into the system. Internal memory can store up to 79,000 measurements. The survey setup was to lay out 100 stainless-steel electrodes at a set distance in a straight line. Watering each electrode reduced the contact resistance. Inverse Schlumberger array data were collected. For a single measurement using this array, the instrument simultaneously uses from 4 to 18 electrodes, one half on either side of a central point. The inner two electrodes transmit current into the earth, whereas the outer electrodes measure the potential difference in the earth. The instrument sequentially switches the transmitter and receiver electrodes along the survey line following instructions in a user-defined command file. One 100-electrode setup acquires data along $500 \mathrm{~m}$ of the traverse. For the longer traverses, at the end of each data run, 20 electrodes were moved from the end of the line to the front of the line and a new data set recorded. This process was repeated until the full length of a line, such as line YFRESEW (fig. 2), was surveyed. 
In 2005 , resistivity stations were located every $5 \mathrm{~m}$ along orthogonal lines that were about 1,500 $\mathrm{m}$ long in the east-west direction (line YFRESEW, fig. 2) and $500 \mathrm{~m}$ long in the north-south direction (line YFRESNS, fig. 2). A 5-m electrode spacing with the R8 DC resistivity system resulted in an investigation depth of approximately $90 \mathrm{~m}$. In 2006, electrode spacings were shortened to $2 \mathrm{~m}$ and were used along 200-m lines (100 electrodes) centered on the surface expression of the Yucca fault in the vicinity of U-7cd (Lines L1 and L2, fig. 2). This electrode spacing resulted in a depth of investigation of approximately $40 \mathrm{~m}$.

\section{Magnetotelluric Investigation}

The MT method is a passive surface geophysical technique that uses the Earth's natural electromagnetic fields to investigate the electrical resistivity structure of the subsurface from depths of tens of meters to tens of kilometers (Vozoff, 1991). Natural variations of the Earth's magnetic and electric field are measured and recorded at each MT station. Worldwide lightning activity at frequencies of 10,000 to 1 hertz $(\mathrm{Hz})$ and geomagnetic micropulsations at frequencies of 1 to $0.001 \mathrm{~Hz}$ provide the majority of the signal sensed by the MT method. The natural electromagnetic waves propagate vertically in the Earth because the large resistivity contrast between the air and the Earth causes a vertical refraction of the electromagnetic wave transmitted into the Earth (Vozoff, 1972).

The natural electric and magnetic fields are recorded in two orthogonal, horizontal directions as well in the vertical direction (named, in magnetotelluric parlance, the "tipper"). The resulting time-series signals are used to derive tensor apparent resistivities and phases by first converting them to complex cross-spectra using Fourier transform techniques. Then a least-squares, cross-spectral analysis (Bendat and Piersol, 1971) is used to solve for a transfer function that relates the observed electric fields to the observed magnetic fields. Before 
conversion to apparent resistivity and phase, the tensor is normally rotated into principal directions that usually correspond to the direction of maximum and minimum apparent resistivity, or the tensor may be rotated perpendicular to the survey traverse.

For a 2-D Earth, in which the Earth's resistivity structure varies with depth and in one lateral direction, the MT fields can then be decoupled into transverse electric (TE) and transverse-magnetic (TM) modes. Two-dimensional (2-D) resistivity modeling is generally computed to fit both modes. When the geology satisfies the 2-D assumption and the MT survey is perpendicular to the geologic strike, the MT data for the TE mode represent the electric field parallel to geologic strike, and the data for the TM mode represent the electric field across strike. The MT method is well suited for studying complicated geological environments because the electric and magnetic relations are sensitive to vertical and horizontal variations in resistivity. The method is capable of establishing whether the electromagnetic fields are responding to subsurface rock bodies of effectively 1, 2, or 3 dimensions. An introduction to the MT method and references for a more advanced understanding are in Dobrin and Savit (1988) and Vozoff (1991). 


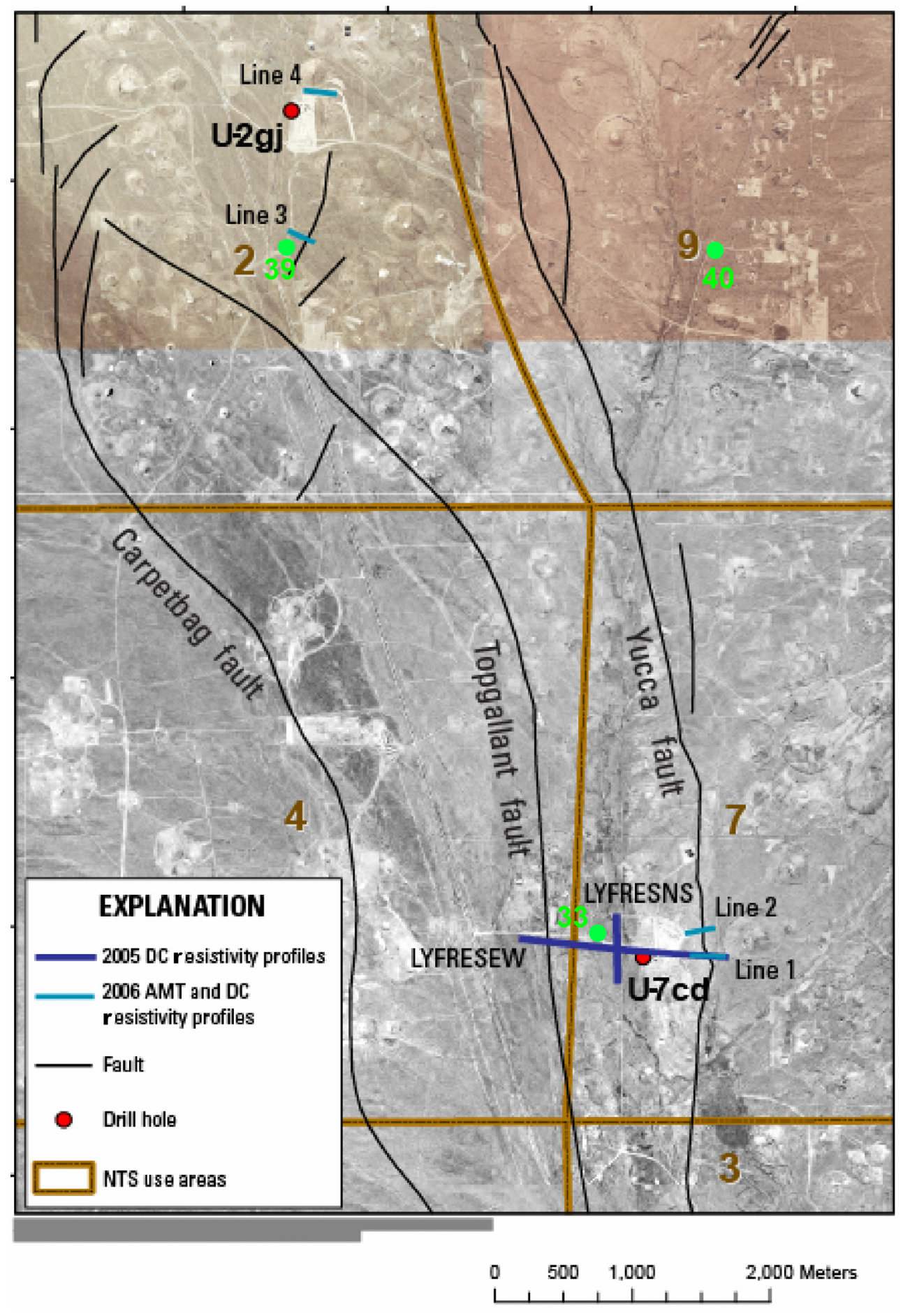

Figure 2. Geophysical study locations on photo mosaic of northern Yucca Flat basin, Nevada Test Site, Nevada. Dark blue lines represent data acquisition in 2005 (Lines YFRESEW and YFRESNS) and the lighter blue lines represent field data acquired in 2006 (Lines 1, 2, 3, and 4). Green dots and labels indicate 2005 regional MT sounding locations in this area. AMT, audiomagnetotelluric; MT, magnetotelluric; DC, direct current; NTS, Nevada Test Site. 


\section{Yucca Flat Magnetotelluric Investigation}

In 2005 the AMT data were acquired with Electromagnetic Instruments, Inc., MT-1 Magnetotelluric system (EMI, 1996). This is a 5-channel, 16-bit, high-frequency (10 Hz to 100 kHz) 3-D tensor MT receiver that uses high-frequency magnetic coils (three EMI BF-6 coils) and titanium electrodes. AMT recording stations were established every $100 \mathrm{~m}$ along the same lines as the 2005 DC resistivity traverses, resulting in 27 soundings. Electric field dipole lengths were $25 \mathrm{~m}$ with, for YFRESEW, Ex positive along the line pointing east and Ey positive pointing south and, for YFRESNS, Ex positive along the line pointing south and Ey positive pointing west. The magnetic field induction coils were oriented parallel to the corresponding electric field components plus the one vertical magnetic field component.

In 2006 Schlumberger/EMI's new MT24/HF, a 6-channel, 24-bit, remote-referencecapable, high-frequency (10 Hz to $100 \mathrm{kHz}) 3-\mathrm{D}$ tensor MT receiver was used for the AMT investigation. EMI BF-6 and BF-16 high-frequency (10 Hz to $100 \mathrm{kHz})$ magnetic induction coils and buffered (amplified, filtered) stainless-steel electrodes are used with this AMT system. The receiver was set up every $20 \mathrm{~m}$ along each of the 200 -m lines (240 $\mathrm{m}$ for Line 1 ) with an effective station spacing, and electric field dipole lengths, of $10 \mathrm{~m}$. Two adjacent electric field dipoles used one set of magnetic field induction coils in order to save station installation time. For all the 2006 AMT lines, Ex was positive in an easterly direction and Ey positive in a southerly direction.

\section{Vertical Gradient Magnetic Field Investigation}

In 2005, along with the DC resistivity and AMT, magnetic field data were acquired along three parallel transects with the center transect coincident with the 2005 east-west AMT and resistivity survey lines and the side transects located approximately $10 \mathrm{~m}$ to either side of the 
center transect. Two Geometrics G-858 magnetometers (self-oscillating split-beam cesium vapor [nonradioactive Cs133]) were configured into a vertical array with a $0.5-\mathrm{m}$ separation. The magnetic field survey consisted of continuously recording, at $10-\mathrm{Hz}$ sampling, the total magnetic field and the vertical gradient of the magnetic field in the vicinity of $\mathrm{U}-7 \mathrm{~cd}$.

\section{Resistivity Results}

\section{Field Effort - Lines YFRESEW and YFRESNS}

The DC resistivity data acquired along these lines were processed and analyzed using AGI's EarthImager 2D modeling and inversion program, (Advanced Geosciences, Inc., 2006). Processing of the DC resistivity consisted of editing out noisy and bad data and checking for abnormal outliers, and determinations were made as to why the outliers exist. The data were then either retained or deleted from the modeling and interpretation process. The resistivity data were collated with the GPS station location and elevation data. The 2-D inversion process was monitored for unusual results caused by accidental inclusion of bad data and for the inversion program's proclivity to include nonexistent conductors that were solely used to reduce the statistical error. Field processing included preliminary 2-D inversions, and the final inversions were topographically corrected. The observed data and calculated model pseduosections are presented in Appendix A along with data misfit pseudosections for each model.

Table 2 lists the 2-D DC inversion modeling parameters for both the 2005 and 2006 field events. Forward modeling followed up the inversions to verify features in the inverted model that were required by the measured field data. 
Table 8. DC resistivity two-dimensional inversion parameters. [Min, minimum; Max, maximum; : -m, ohm-meters; V, volts; I, amperes; mV, millivolts; \%, percent; NTSL, Nevada Test Site Line; --, no data; horiz., horizontal; vert., vertical; abs, absolute value]

\begin{tabular}{|c|c|c|c|c|c|}
\hline DC inversion parameters & YFRESEW & NTSL01 & NTSL02 & NTSL03 & NTSL04 \\
\hline Mesh thickness incremental factor & \multicolumn{5}{|c|}{1.1} \\
\hline Depth factor & \multicolumn{5}{|c|}{1.1} \\
\hline Min number mesh cells between electrodes & \multicolumn{5}{|c|}{2} \\
\hline Min voltage accepted $(\mathrm{mV})$ & \multicolumn{5}{|c|}{0.2} \\
\hline Min abs $(\mathrm{V} / \mathrm{I})$ accepted $(\Omega)$ & \multicolumn{5}{|c|}{0.0005} \\
\hline Max repeat error accepted (\%) & \multicolumn{5}{|c|}{3} \\
\hline Min apparent resistivity accepted $(\Omega-\mathrm{m})$ & \multicolumn{5}{|c|}{1} \\
\hline Max apparent resistivity accepted $(\Omega-\mathrm{m})$ & \multicolumn{5}{|c|}{10,000} \\
\hline Inversion method & \multicolumn{5}{|c|}{ Robust } \\
\hline Max number of iterations & \multicolumn{5}{|c|}{10} \\
\hline Max RMS model error (\%) & \multicolumn{5}{|c|}{3} \\
\hline Starting model $(\Omega-m)$ & 113.81 & 265.84 & 283.29 & 231.97 & 164.43 \\
\hline Min output resistivity $(\Omega-\mathrm{m})$ & \multicolumn{5}{|c|}{10} \\
\hline Max output resistivity $(\Omega-\mathrm{m})$ & \multicolumn{5}{|c|}{1,000} \\
\hline Horiz./Vert. Roughness Ratio & \multicolumn{5}{|c|}{0.1} \\
\hline Stabilizing factor (Lagrange multiplier) & \multicolumn{5}{|c|}{100} \\
\hline Damping factor & \multicolumn{5}{|c|}{100} \\
\hline Model parameter width (horiz. smoothing) & \multicolumn{5}{|c|}{1} \\
\hline Model parameter height (vert. smoothing) & \multicolumn{5}{|c|}{1} \\
\hline Resolution factor (rough conditioner) & \multicolumn{5}{|c|}{0.2} \\
\hline Robust data conditioner $\left(\varepsilon_{\mathrm{D}}\right)$ & \multicolumn{5}{|c|}{1} \\
\hline Robust model conditioner $\left(\varepsilon_{M}\right)$ & \multicolumn{5}{|c|}{1} \\
\hline $\begin{array}{l}\text { Data points removed from misfit } \\
\text { histogram (\%) }\end{array}$ & -- & 3.2 & 3.7 & 1.0 & 1.3 \\
\hline Data misfit cutoff $(\%)$ & -- & 20 & 20 & 10 & 8 \\
\hline
\end{tabular}

The modeling results for the 2005 DC resistivity survey along line YFRESEW, presented in figure 3, show that the western end of the DC resistivity inversion has a 100-200 ohm-m unit from the beginning to approximately a 300-m distance along the line. The projected surface trace of the Topgallant fault crosses the section between about 100 and $200 \mathrm{~m}$. There are slight changes in resistivity at this location; DC resistivity is complex between 200 and $300 \mathrm{~m}$, possibly as a result of fault effects. From the 300-m mark to around 1,100-1,200 m, the near-surface geology is somewhat electrically conductive, about 50-100 ohm-m; at depth, there is a distinct 
change to a more resistive unit, from about the 950-m to 1,200-m mark, that appears to dip west at about 20 degrees. Based on lithology intercepted in drill hole U-7cd, the resistivity change with depth appears to correspond to a lithology change from porous gravels above to coarse sand below; the dip of this surface is consistent with the dip in the underlying tuff units. East of 1,200 $\mathrm{m}$ distance, the near-surface geology becomes generally more resistive; two mapped splays of the Yucca fault cross the section in this area.

The DC resistivity results for the shorter north to south line, YFRESNS, are presented in figure 4. It appears that no major geologic structural features were crossed except possibly the electrically conductive structure located between $60 \mathrm{~m}$ and $100 \mathrm{~m}$. This short line is located in the footwall of the Yucca fault, well to the west of the fault trace. The results from this line are consistent with the somewhat electrically conductive (around 50-100 ohm-m) central part of the east-west line YFRESEW. 


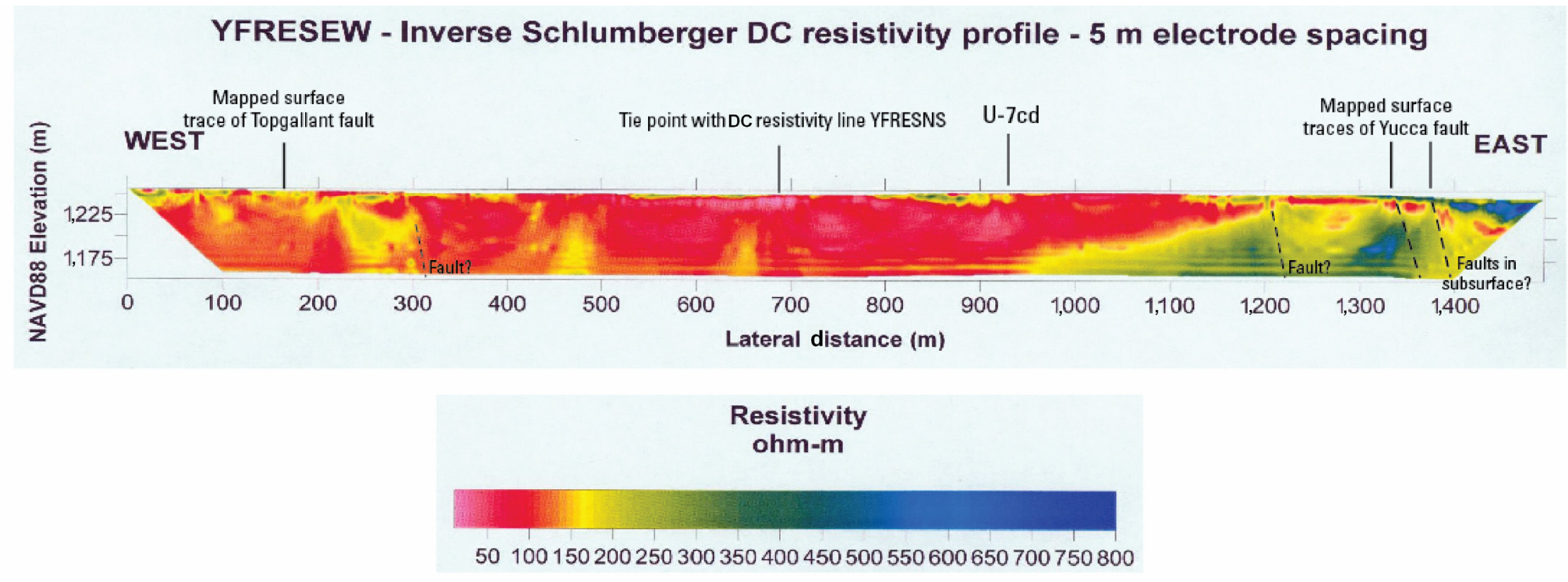

Figure 3. Yucca Flat DC resistivity two-dimensional inversion modeling results for line YFRESEW acquired in 2005 at the Nevada Test Site, Nevada. Black dashed lines indicate interpreted fault crossings. Location of drill hole U-7cd indicated with a black line at around 930 meters along the traverse. [m, meters; ohm-m, ohm-meters, NAVD88, North American Vertical Datum of 1988] 


\section{YFRESNSAa_trial6.stg}

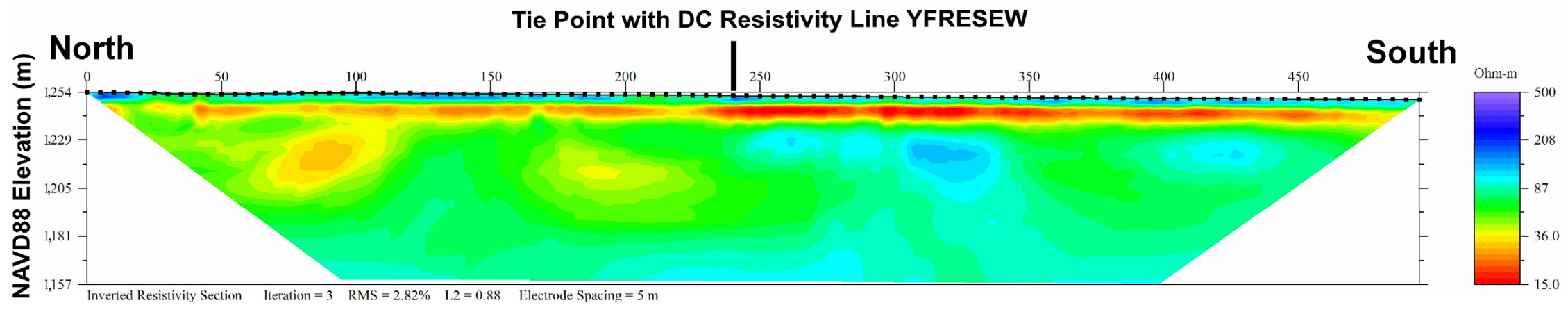

Figure 4. Yucca Flat DC resistivity two-dimensional modeling and inversion results for YFRESNS, the north-south profile acquired in 2005 at the Nevada Test Site, Nevada. [Ohm-m, ohm-meters; m, meters; NAVD88, North American Vertical Datum of 1988] 


\section{Field Effort}

The DC resistivity results from lines 1 and 2 near the southern drill hole, $\mathrm{U}-7 \mathrm{~cd}$, are presented first, followed by results from lines 3 and 4 from near the northern drill hole, $\mathrm{U}-2 \mathrm{gj}$.

\section{Near U-7cd - Lines 1 and 2}

The DC resistivity results for Line 1 are presented in figure 5. All the survey traverses progressed from west to east (left to right in the figures). There is a rapid change in topography at the location of the Yucca fault escarpment, which is approximately located at 100-m distance in figure 5. To the west of the Yucca fault escarpment the DC resistivity results indicate thin resistive material (500-1,000 ohm-m) overlying more conductive material (100-200 ohm-m). There is a discontinuity in the conductive material at the approximate location of the Yucca fault surface expression and again at the 160-m distance along the line. The conductivity change at the 160-m distance (more pronounced than the break at 100-110 m) is likely an expression of another subsurface fault that appears to be an en-echelon splay of the Yucca fault zone.

The DC resistivity inversion results (fig. 6) for Line 2 show a marked conductivity contrast across the location of the surface expression of the Yucca fault (around 100-m distance along the line). There is a smaller conductivity contrast at approximately the $150-\mathrm{m}$ distance along the line that could represent a northern extension of the eastern fault observed on Line 1 at the 160-m distance. 


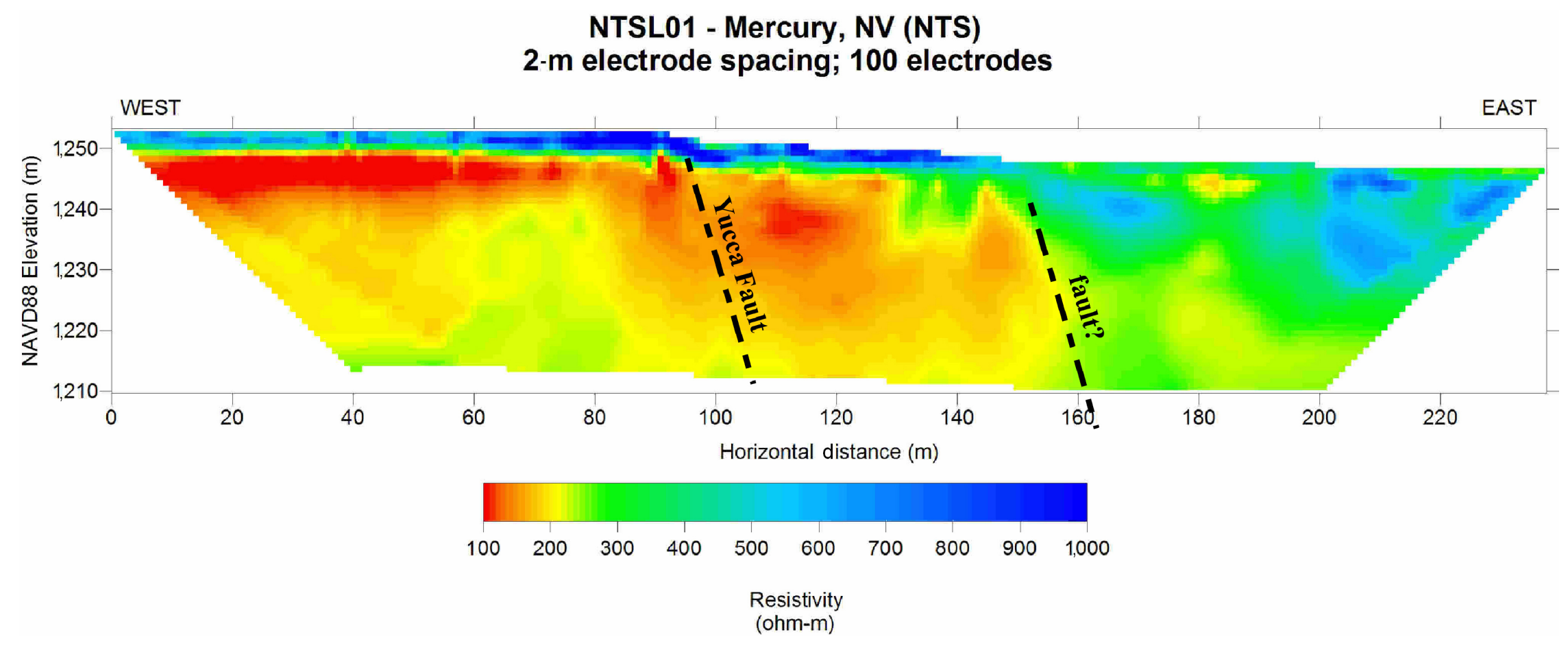

Figure 5. DC resistivity two-dimensional inversion results for Line 1 (fig. 2) of 2006 field effort at the Nevada Test Site, Nevada. [m, meters; NV, Nevada; NTS, Nevada Test Site; ohm-m, ohm-meters; NAVD88, North American Vertical Datum of 1988] 


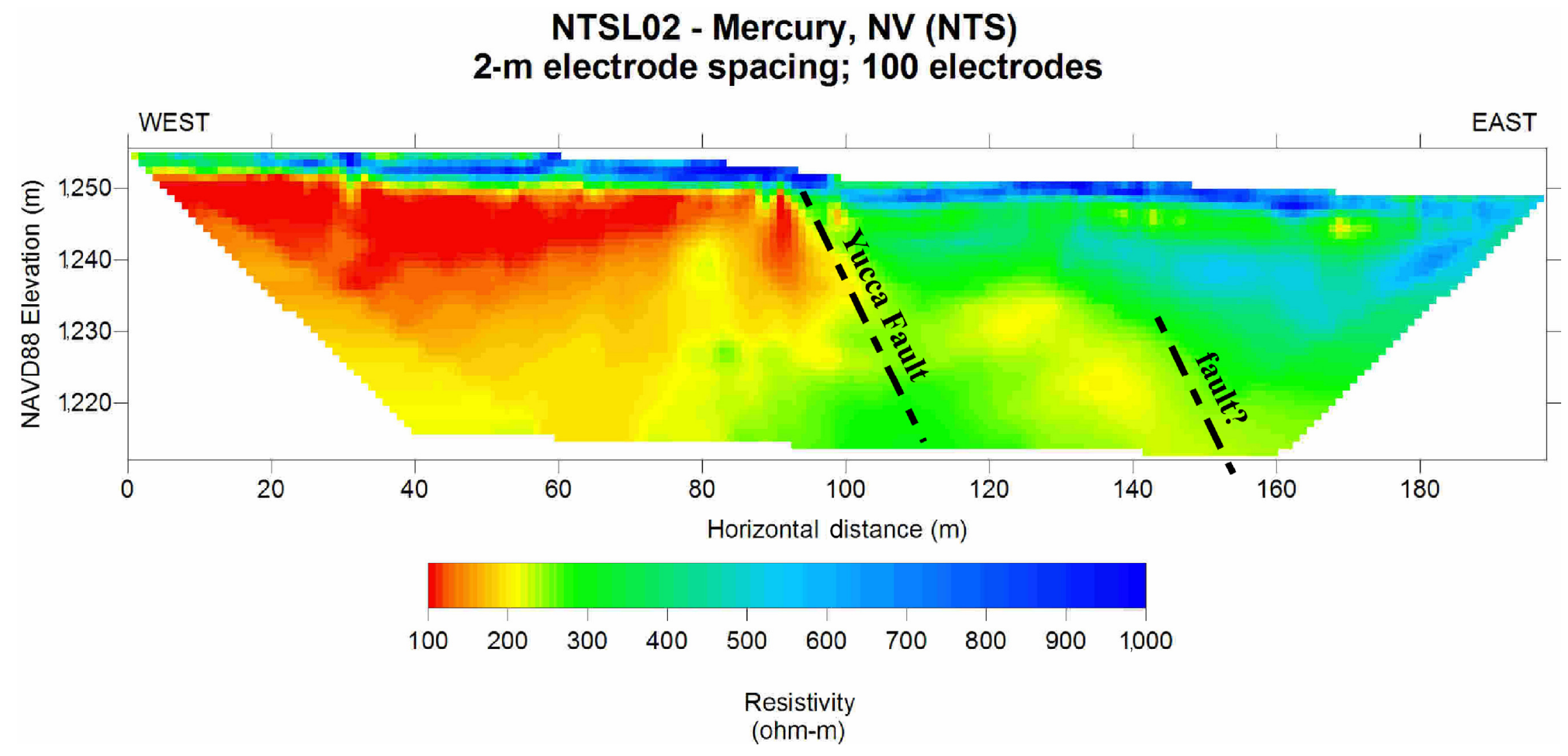

Figure 6. DC resistivity two-dimensional inversion results for Line 2 (fig. 2) of 2006 field effort at the Nevada Test Site, Nevada. [m, meters; NV, Nevada; NTS, Nevada Test Site; ohm-m, ohm-meters; NAVD88, North American Vertical Datum of 1988] 
Near U-2gj — Lines 3 and 4

Line 3 is located south of drill hole U-2gj (fig. 2) in the northern end of Yucca Flat basin. The DC resistivity inversion results (fig. 7) for line 3 show slight conductivity contrasts (between the green (150-200 ohm-m) and blue colors (300-400 ohm-m) along the traverse that may be due to near-surface shallow faulting. Possible fault locations along the line are at distances $48 \mathrm{~m}$, $85 \mathrm{~m}, 115 \mathrm{~m}, 140 \mathrm{~m}$, and $155 \mathrm{~m}$. The slight conductivity contrasts indicate that the faulting is likely within the same or closely related lithological unit.

Line 4 is located just north of drill hole $\mathrm{U}-2 \mathrm{gj}$ (fig. 2). The DC resistivity inversion results for line 4 are presented in figure 8 . As with line 3, only slight conductivity contrasts in the near surface could be related to traces of shallow faulting. Possible faults are located at $38 \mathrm{~m}, 82$ $\mathrm{m}, 100 \mathrm{~m}$, and $147 \mathrm{~m}$ along the traverse. It was observed during data acquisition along line 4 that a shallow trench had been cut across a fault at a distance along the line of about $100 \mathrm{~m}$. This trench forms the basis for the faults in the subsurface indicated in figure 8 . 


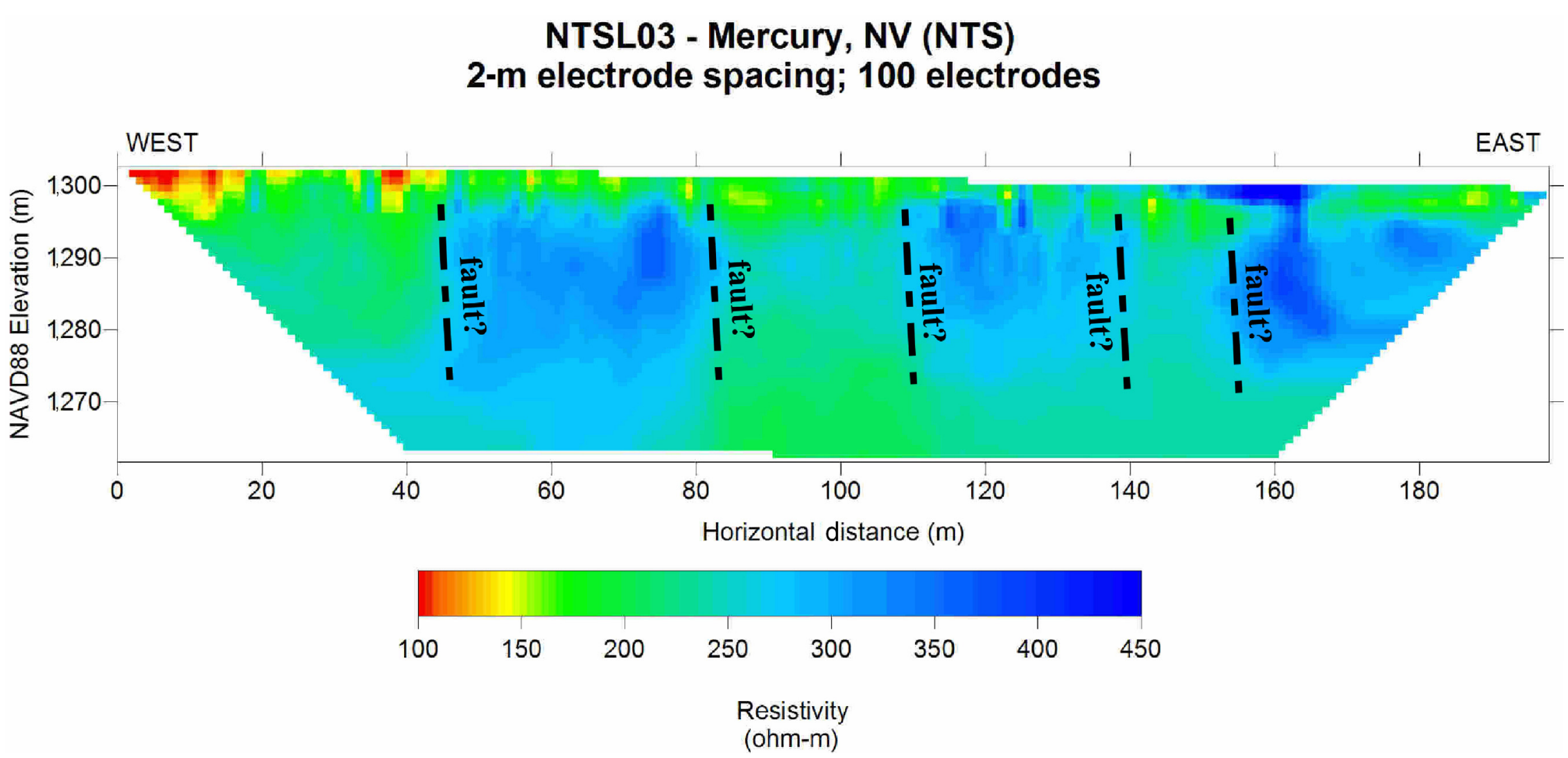

Figure 7. DC resistivity two-dimensional inversion results for Line 3 (fig. 2) of 2006 field effort at the Nevada Test Site, Nevada. [m, meters; NV, Nevada; NTS, Nevada Test Site; ohm-m, ohm-meters; NAVD88, North American Vertical Datum of 1988] 


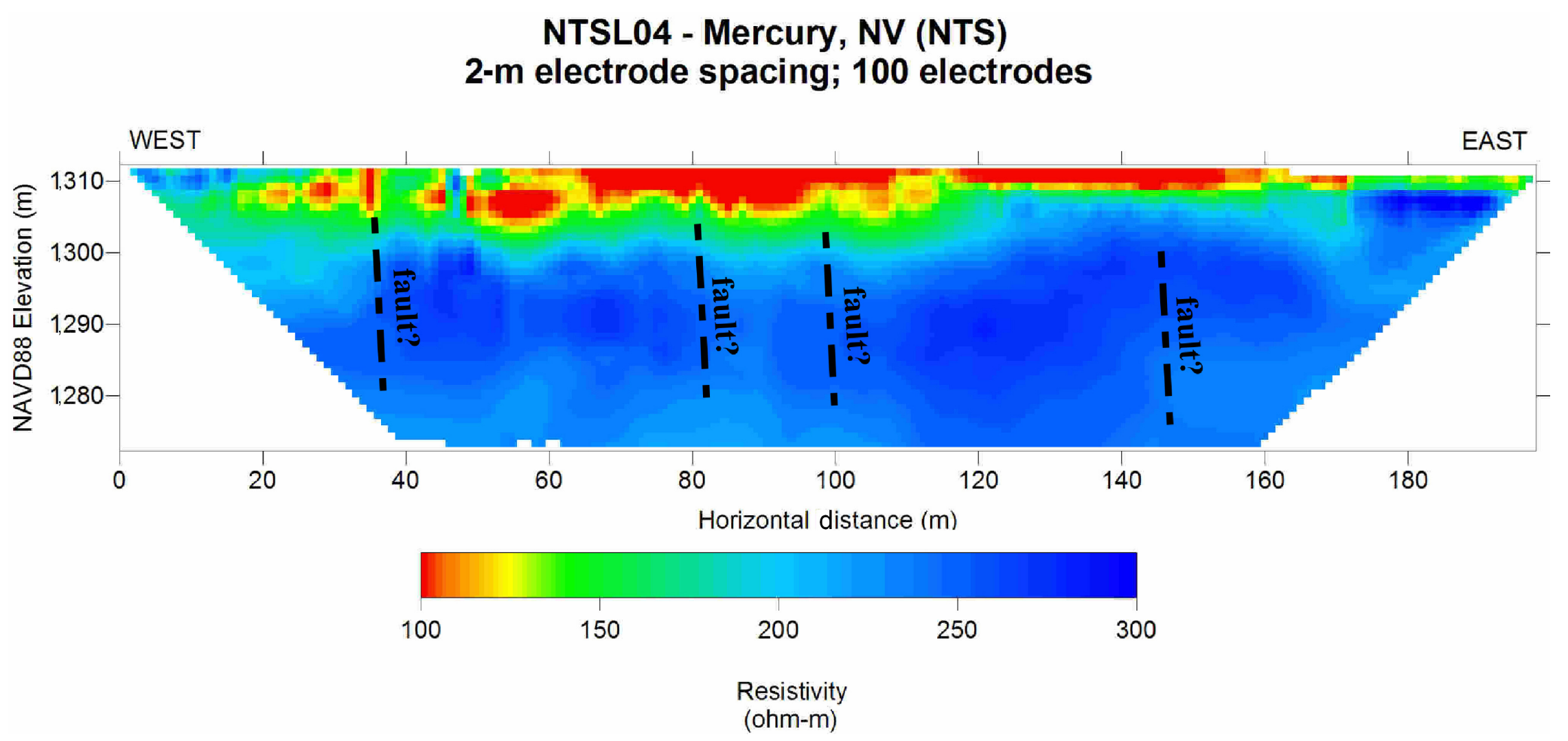

Figure 8. DC resistivity two-dimensional inversion results for Line 4 (fig. 2) of 2006 field effort at the Nevada Test Site, Nevada. [m, meters; NV, Nevada; NTS, Nevada Test Site; ohm-m, ohm-meters; NAVD88, North American Vertical Datum of 1988] 


\section{Audio Magnetotelluric Results}

In this investigation, the recorded time-series data were transformed to the frequency domain and processed to determine a 2-D apparent resistivity and phase tensor at each site. Time-series data sets were selected for optimal signal-to-noise characteristics prior to the crosspower calculations. Cross-power files were created with Egbert's (1997) multiple-station, remote-reference magnetotelluric data-processing algorithms used in single-station local remote reference mode. During the analysis and interpretation process, each station was rotated to a fixed angle determined by the given nominal profile orientation. Rotation of the impedance tensor allows for decoupling into the TE and TM modes. Table 9 lists the nominal line azimuths and the fixed, orthogonal angles of rotation for each profile. The 2005 time-series data were edited with EMI's MTR15 MT data-processing program and the 2006 data with ACQ24, EMI's 24-bit MT data-analysis program (EMI, 2002), to remove noisy data points and calculate spectral crosspowers. The different programs were used because two different MT systems acquired the data. The data recorded in 2006 with the new MT24/HF were generally quite noisy, and in some cases, a few stations were not used in the inversion analysis along the profiles.

Table 9. AMT profile azimuths and angles of rotation applied during processing.

\begin{tabular}{cccc}
\hline Profile number & $\begin{array}{c}\text { MT stations } \\
\text { in profile }\end{array}$ & $\begin{array}{c}\text { Profile azimuth } \\
\text { (degrees) }\end{array}$ & $\begin{array}{c}\text { Fixed angle of rotation } \\
\text { (degrees) }\end{array}$ \\
\hline 2005 YFRESEW & 16 & 95 & 5 \\
2005 YFRESNS & 6 & 180 & 90 \\
2006 Line 1 & 24 & 90 & 0 \\
2006 Line 2 & 20 & 90 & 0 \\
2006 Line 3 & 20 & 109 & 19 \\
2006 Line 4 & 20 & 89 & -1 \\
\hline
\end{tabular}


The effects of near-surface resistivity anomalies can cause what are known as "static shifts" in the data (Sternberg and others, 1988). Cultural features also can affect the measured magnetotelluric responses. These include fences, pipelines, communication lines, railways, and other manmade conductors. The data acquired near the tower at U-7cd were somewhat affected by the infrastructure. There were no cultural issues near U-2gj. Otherwise, cultural features were not an issue during this investigation.

The raw and model controlled source AMT data are presented in Appendix B. For each station, the following images are presented: Apparent Resistivity, Impedance Phase, E-Predicted Coherencies, Impedance Skew, Impedance Polar Plots, Rotation Angle, Tipper Magnitude, and Tipper Strike. Error bars (],[) on the Apparent Resistivity and the Impedance Phase plots represent probable errors within one standard deviation of the sample variance (Gamble and others, 1979).

Apparent resistivity is the approximate ratio of the electric field strength to the magnetic field strength at a given frequency. The impedance phase is proportional to the slope of the apparent resistivity curve on a $\log$ - $\log$ plot, but from baselines at \pm 45 degrees (Vozoff, 1991). A measure of the dimensionality for MT data is provided by the impedance skew of the impedance tensor (Vozoff, 1972). If the effective measured resistivity response to the geology beneath an MT station truly is one or two dimensional, then the skew will be zero. Instrument and environmental sources of electrical noise can cause nonzero skew values. Skew values typically are small (about 0.1 ) for relatively low noise recordings. Higher skews (above 0.2) are an indication of either the resistivity response to 3-D geology or higher levels of noise. Manmade electrical noise, such as power lines, power generators, and moving vehicles and trains, can have a negative effect on MT data quality. All of these local disturbances can produce incoherent noise that mainly affects frequencies above $1 \mathrm{~Hz}$. Other manmade electrical noise, such as direct 
current electric trains and active cathodic protection of pipelines, produces coherent electromagnetic signals that mainly affect frequencies below $1 \mathrm{~Hz}$.

In the survey area, noise from a number of small power lines and small moving vehicles was negligible at distances greater than $0.4 \mathrm{~km}$ from the noise source. Power-line signal levels were measured at each site and typically were less than 20 percent of the maximum recordable signals. Noise from larger power lines, power generators, pipelines, and trains was negligible at distances greater than $5 \mathrm{~km}$. Local lightning, wind, and rainstorms also can degrade data quality. Burying the magnetic induction coils and the electric dipole wires minimized wind noise.

Predicted values of the electric field can be computed from the measured values of the magnetic field (Vozoff, 1991). The coherence of the predicted electric field with the measured electric field is a measure of the signal-to-noise ratio provided in the multiple coherency plots. Values are normalized between 0 and 1; values at 0.5 signify signal levels equal to noise levels. For this data set, coherencies generally were at an acceptable level, except at times in the frequency ranges of 0.01 to $5 \mathrm{~Hz}$ (often referred to as the "dead band").

These controlled source AMT data include some scatter and very poor signal-to-noise ratios. Spectral results were inspected visually for noisy data, and the best signal-to-noise field data were combined into the final plots and spectral data sets. In some cases most of the data at a site was almost totally removed from the analysis. This occurred primarily with the 2006 data as a new system, the MT24/HF, was being field tested for the first time; therefore many acquisition issues became evident as the data were acquired.

The magnetotelluric impedance polar plots provide a measure of MT data dimensionality (Reddy and others, 1977). For 1-D resistivity structures, the principal impedance polar diagram (dashed line) is a circle. For 2-D or 3-D resistivity structures, the principal impedance polar diagram (dashed line) elongates either parallel or perpendicular to strike direction. Over resistors, 
the principal impedance polar diagram elongates perpendicular to strike direction, and over conductors, it elongates parallel to strike direction. For 2-D resistivity structures, the additional impedance polar diagram (solid line) attains the shape of a symmetric cloverleaf. For 3-D resistivity structures, the additional impedance polar diagram (solid line) elongates in one direction, and its amplitude is comparable to that of the principal impedance polar diagram (dashed line).

The magnetotelluric "tipper" is calculated from the vertical component of the magnetic field. The tipper magnitude is a measure of the "tipping" of the magnetic field out of the horizontal plane (Vozoff, 1991). It will be equal to zero for the 1-D case. Typically, the tipper value is between 0.1 to 0.5 and seldom approaches 1.0 . The tipper responds primarily to vertical and subvertical structures. The tipper magnitude of the stations discussed in this report ranged from 0.1 to 0.6 over the lower frequencies. This indicates some lateral contacts or vertical structure at depth. The tipper strike is used to help resolve the 90-degree ambiguity in the impedance rotation angle. The $\mathrm{HzHx}$ and $\mathrm{HzHy}$ coherency is a measure of the signal-to-noise ratio of the vertical magnetic field with respect to each of the orthogonal, horizontal magnetic field components. Values are normalized between 0 and 1; values at 0.5 signify signal levels equal to noise levels. These three-component magnetic field coherencies provide a check on the signal-to-noise ratio of the measured values in the tipper magnitude and tipper strike plots.

\section{Two-Dimensional Modeling Analysis of the AMT Data}

A two-dimensional modeling analysis of the Yucca Flat CSAMT data has been performed. Wannamaker (1983) found that while some MT responses in the Basin and Range region are fundamentally three-dimensional (3-D) in nature, for elongated structures, 2-D modeling could be used to construct reasonable estimates of the resistivity cross sections along each profile. Wannamaker and others (1984) demonstrated that approximating 3-D structure 
beneath a centrally located profile with 2-D modeling is best achieved when fitting the TM curve, even at the expense of a poor fit of the TE curve. However, because TM data are relatively insensitive to the depth extent of a subsurface body (Eberhart-Phillips and others, 1995), the depths to the base of the bodies in the model are not well constrained. Hence, clarifying the model limits with 3-D resistivity modeling may be necessary.

Two dimensional resistivity models were constructed for each profile. First, 2-D inversions of the audio magnetotelluric data were conducted using the computer program, RLM2DI (Mackie and others [1997] and Rodi and Mackie [2001]), from within GEOTOOLS (Geotools, 1998), a shell program specifically designed to process and interpret MT and AMT data. This was followed by the application of the 2-D forward modeling algorithm program, PW2D, developed by Wannamaker and others (1987). The results of the RLM2DI 2-D inversion were used as the initial input model for the forward modeling, PW2D, where a sensitivity analysis was performed on the conductive structures derived from the inversion results.

RLM2DI uses a finite-difference network analog to the Maxwell's equations governing magnetotellurics to calculate the forward solution and a nonlinear conjugate gradient optimization approach that is applied directly to the minimization of the objective function for the inverse problem. PW2D is a stable finite-element algorithm that simulates transverse electric and magnetic fields using a linear basis across each finite element. The inversion algorithm, RLM2DI, was usually allowed to batch run 25 iterations in order to reduce the root mean square (RMS) error to a reasonable value between the field data and the numerical model. The number of iterations of forward modeling (PW2D) necessary depended on how complex the profile inversion results were from RLM2DI.

Table 10 lists the number of horizontal and vertical nodes that were used in the modeling for each profile. The variability in the number of nodes from profile to profile is due to the 
different number of MT stations along each profile. In all cases the number of horizontal and vertical nodes necessary for the iterative forward modeling (PW2D) algorithm to accurately model the Yucca Flat subsurface resistivity distribution is greater than the number of nodes required by the inversion algorithm (RLM2DI). This is a function of some fundamental differences between how finite-difference and finite-element algorithms handle the numerical boundary conditions and, subsequently, how the electric and magnetic fields are calculated across the mesh.

Table 10. Inversion (RLM2DI) and forward (PW2D) numerical model meshes for each profile. The number of horizontal (Horiz) nodes and vertical (Vert) nodes in each model mesh are listed. [-, PW2D not run]

\begin{tabular}{crlrrr}
\hline \multirow{2}{*}{$\begin{array}{c}\text { Profile } \\
\text { no. }\end{array}$} & \multicolumn{2}{c}{ RLM2DI } & & \multicolumn{2}{c}{ PW2D } \\
\cline { 5 - 6 } \cline { 5 - 5 } & Horiz & Vert & Horiz & Vert \\
\hline YFRESEW & 69 & 59 & & 94 & 63 \\
YFRESNS & 69 & 59 & & 85 & 59 \\
Line 1 & 116 & 50 & & 140 & 50 \\
Line 2 & 100 & 59 & & 100 & 59 \\
Line 3 & 88 & 59 & & 89 & 56 \\
Line 4 & 91 & 59 & - & - \\
\hline
\end{tabular}

The edges of the model were extended horizontally and vertically to minimize edge effects. The resolution of the resistivity boundaries used for each model is somewhat subjective. If different resistivities were used, then boundary positions and layer depths would have to be adjusted to achieve similar fits to the observed data. The extreme case would be to use a model with a "continuous" resistivity gradient from low to high resistivities. The resolution of the resistivity boundaries is also, in part, a function of the model grid mesh design. We have attempted to keep each model simple. The MT profiles models' depths are relative to the Earth's surface. Nine additional vertical nodes are usually added to model the overlying air layer. 


\section{Field Effort - Lines YFRESEW and YFRESNS}

The AMT interpreted resistivity model for the TM mode for line YFRESEW, acquired in 2005, is presented in figure 9. The AMT and DC resistivity inversion models (figs. 9 and 3, respectively) for line YFRESEW appear to agree over the 100-m depth at which the resistivity models overlap. In this depth range, a generally conductive section is disrupted on the west end of the section (between 200 and $300 \mathrm{~m}$ ) by the Topgallant fault; a distinct change in resistivity east of $1,100 \mathrm{~m}$ is related to offset on the Yucca fault. A resistive section in figure 9 between $0 \mathrm{~m}$ and $300 \mathrm{~m}$ along the line at depths of $100 \mathrm{~m}$ to $225 \mathrm{~m}$ may represent an alluvial unit. The most conductive part of the section occurs between 300- and 600-m depth and corresponds to the partly welded parts of Timber Mountain Group rocks. The Topgallant fault is interpreted to cut the electrically resistive alluvium and more conductive volcanic units on the western end of the generally east-west line, and Yucca fault is interpreted to cross the section on the eastern end of the line. There is no surface expression of faulting on the western end of the line. However, surface offset is observed at approximately 1,350 $\mathrm{m}$ at the eastern end of the line where Yucca fault crosses the profile. Another subsurface fault may cross the section at $950 \mathrm{~m}$ along the profile (indicated in the figure) just beneath $\mathrm{U}-7 \mathrm{~cd}$. The thin red line in figure 9 at approximately 90-m depth indicates the interpreted depth of the DC resistivity inversion presented in figure 3.

The 2005 east-west AMT and DC resistivity transects, lines YFRESEW, are approximately co-linear with a longer magnetotelluric profile from a regional study of the resistivity structure of the Yucca Flat basin (Asch and others, 2006). Line YFRESEW is located near station 33 (fig. 2) in that study. The regional interpreted resistivity model (fig. 10) shows good agreement with the detailed AMT fault study interpretation (fig. 9) in the near surface. The top of the generally more conductive volcanic section appears in both profiles at about 500-m 
depth, overlain by more resistive alluvium and, in the case of the MT data, shown to be underlain by resistive Paleozoic carbonate rocks (fig. 10).

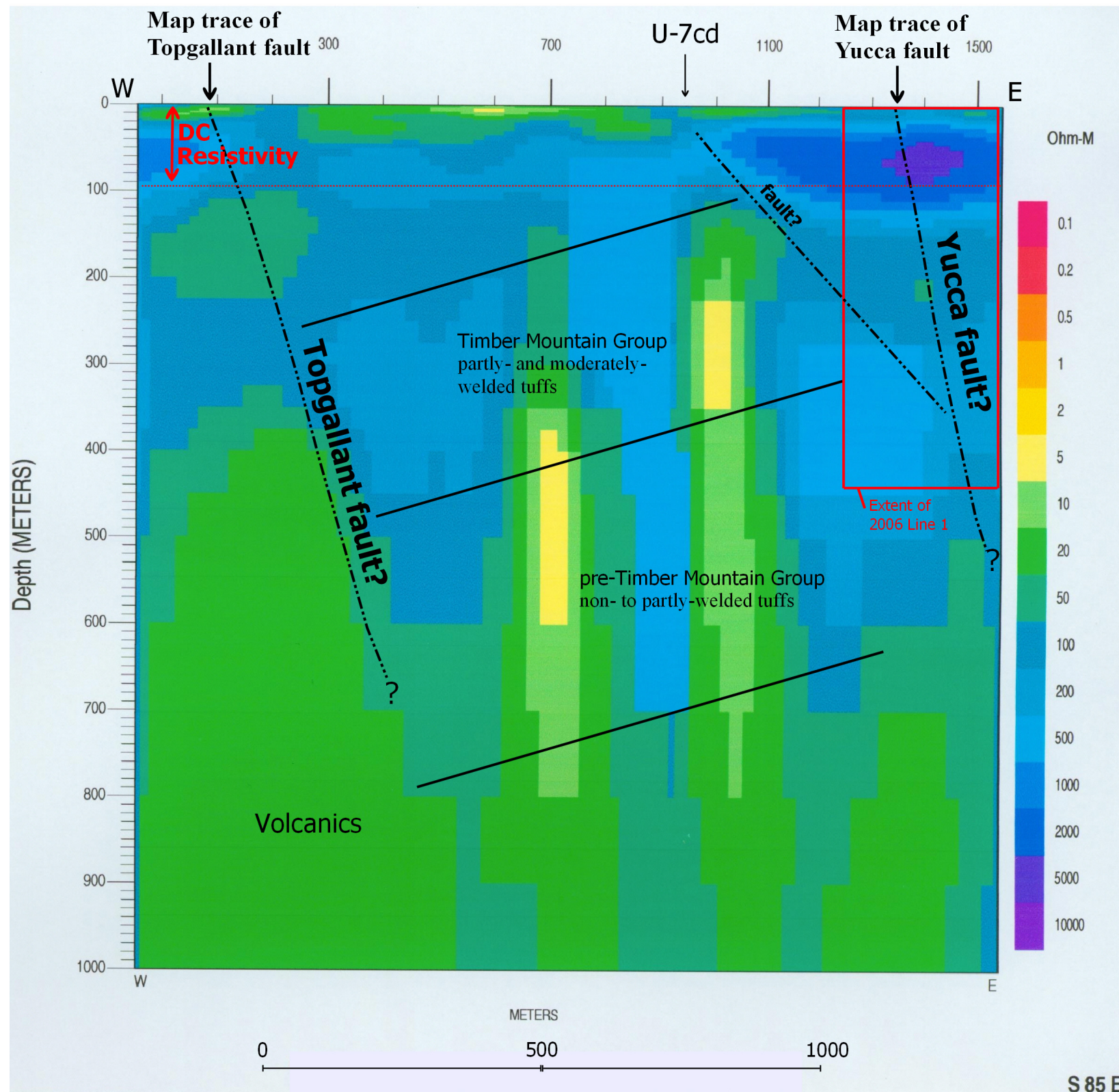

Figure 9. Yucca Flat detailed fault study - two-dimensional AMT inversion modeling results for the transverse-magnetic (TM) mode along line YFRESEW. The interpreted positions of the Topgallant and Yucca faults are indicated by dashed black lines. The depth overlapping with the DC resistivity results (fig. 3 ) is demarcated with a red dashed line at approximately 100-meter depth. A black arrow indicates the location of drill hole U-7cd. 

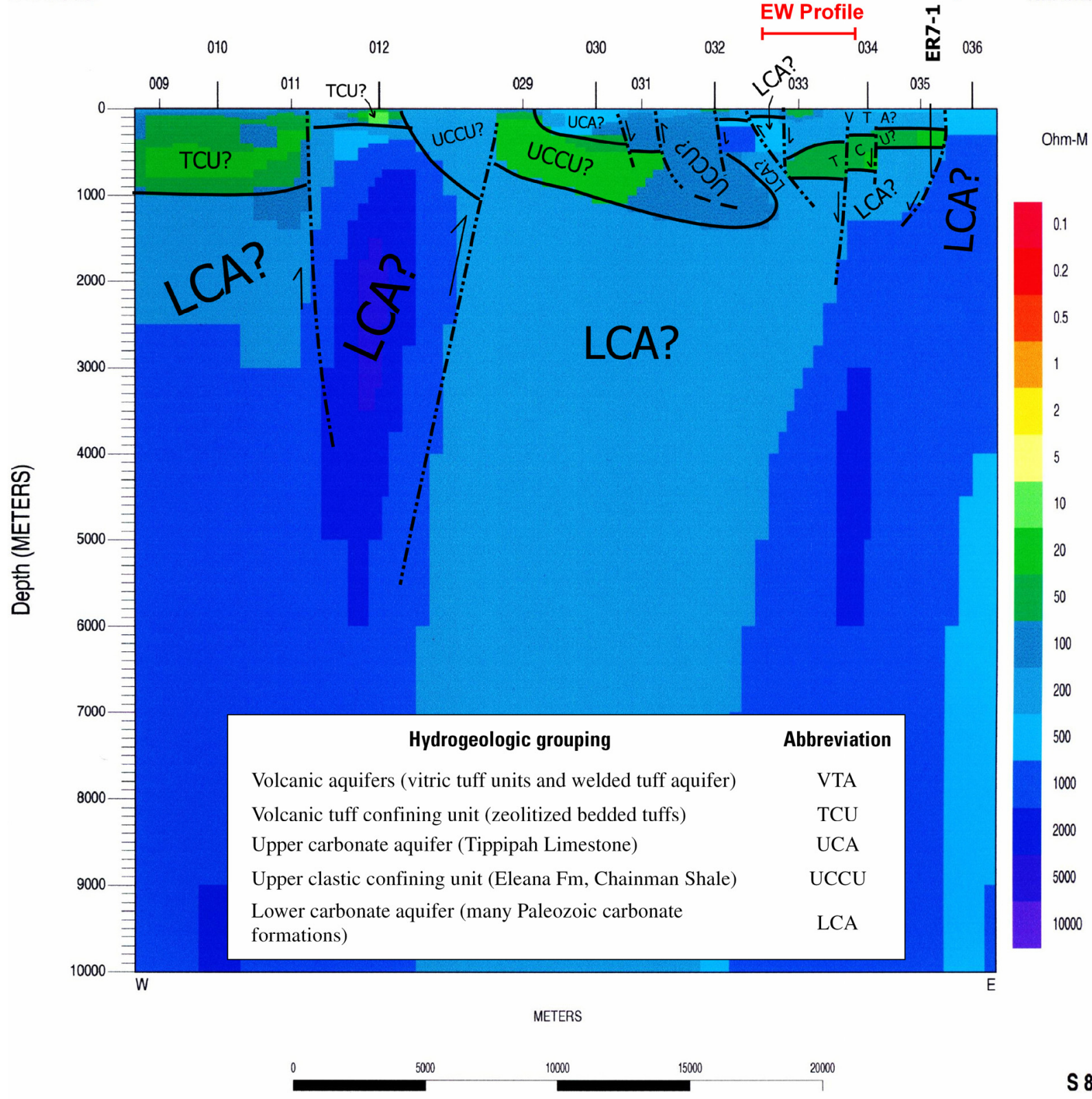

Figure 10. Two-dimensional MT inversion and forward modeling results from the Yucca Flat regional deep resistivity study (Asch and others, 2006) at the Nevada Test Site, Nevada. Inferred faults are indicated by dashed black lines. Abbreviations indicate major lithologic subdivisions, based in part on hydrogeologic nomenclature of Winograd and Thordarson (1975). The red line indicates the extent of the east-west detailed profile shown in figure 9. 
The AMT inversion result for the TM mode for the north to south line acquired in 2005, YFRESNS, is presented in figure 11. This figure shows an electrically conductive section (approximately 10 to $22 \mathrm{ohm}-\mathrm{m}$ ) for the first 100-m depth with more resistive units (100 to 500 ohm-m) developing under stations 0, 100, 400 and 500 along the line. The interpreted geology under the station at $200 \mathrm{~m}$ along the line is more conductive $(10 \mathrm{ohm}-\mathrm{m})$ than the surrounding material at the same depth (22-50 ohm-m). Line YFRESEW crosses line YFRESNS at approximately $240 \mathrm{~m}$ along the traverse.

Compare this north-south section (fig. 11) at $240 \mathrm{~m}$ to the TE mode results for line YFRESEW presented in figure 12. Line YFRESNS crosses line YFRESEW at approximately $690 \mathrm{~m}$ as shown in the figure. Both figures show similar conductive and resistive depth sections at their respective locations. This illustrates the expected orthogonal relationship between the TM and TE modes of magnetotelluric surveying.

However, it should be noted that the inferred fault under hole U-7cd and Yucca fault are likely affecting the natural electrical current flow that is being observed along line YFRESNS. The proximity of this line to these faults and the orientation of line YFRESNS, approximately north to south, is affecting exactly what is being recorded as the observed MT signal. The effect is that what should be the TE mode data on line YFRESNS (that is, current flow perpendicular to the traverse direction) is more likely an approximate representation of the TM mode, and the reverse, because of the restriction of current flow by the fault. 


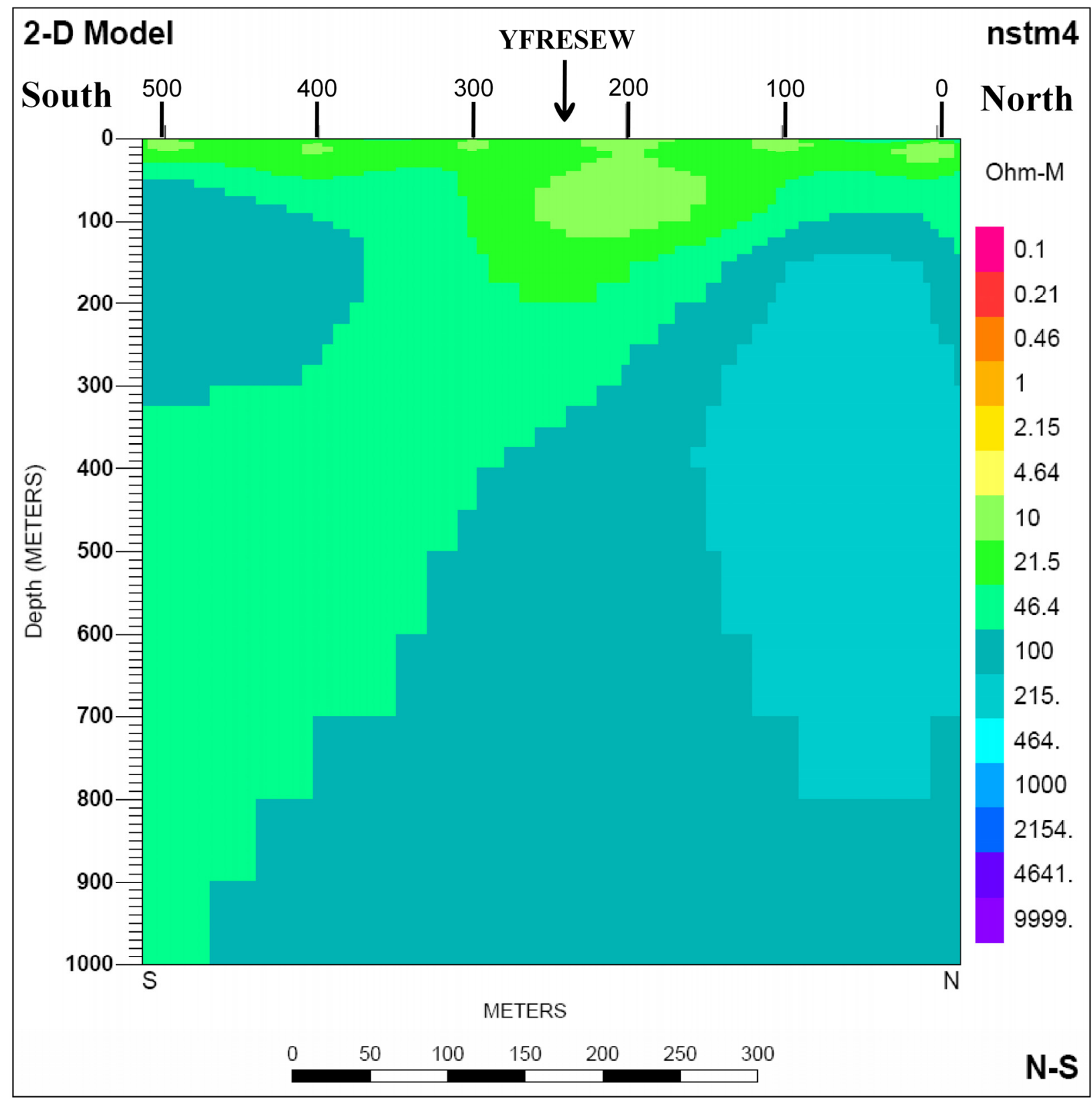

Figure 11. Two-dimensional AMT inversion modeling results for 2005 line YFRESNS, at the Nevada Test Site, Nevada. Line YFRESEW crosses this line at approximately 240 meters along the traverse. 


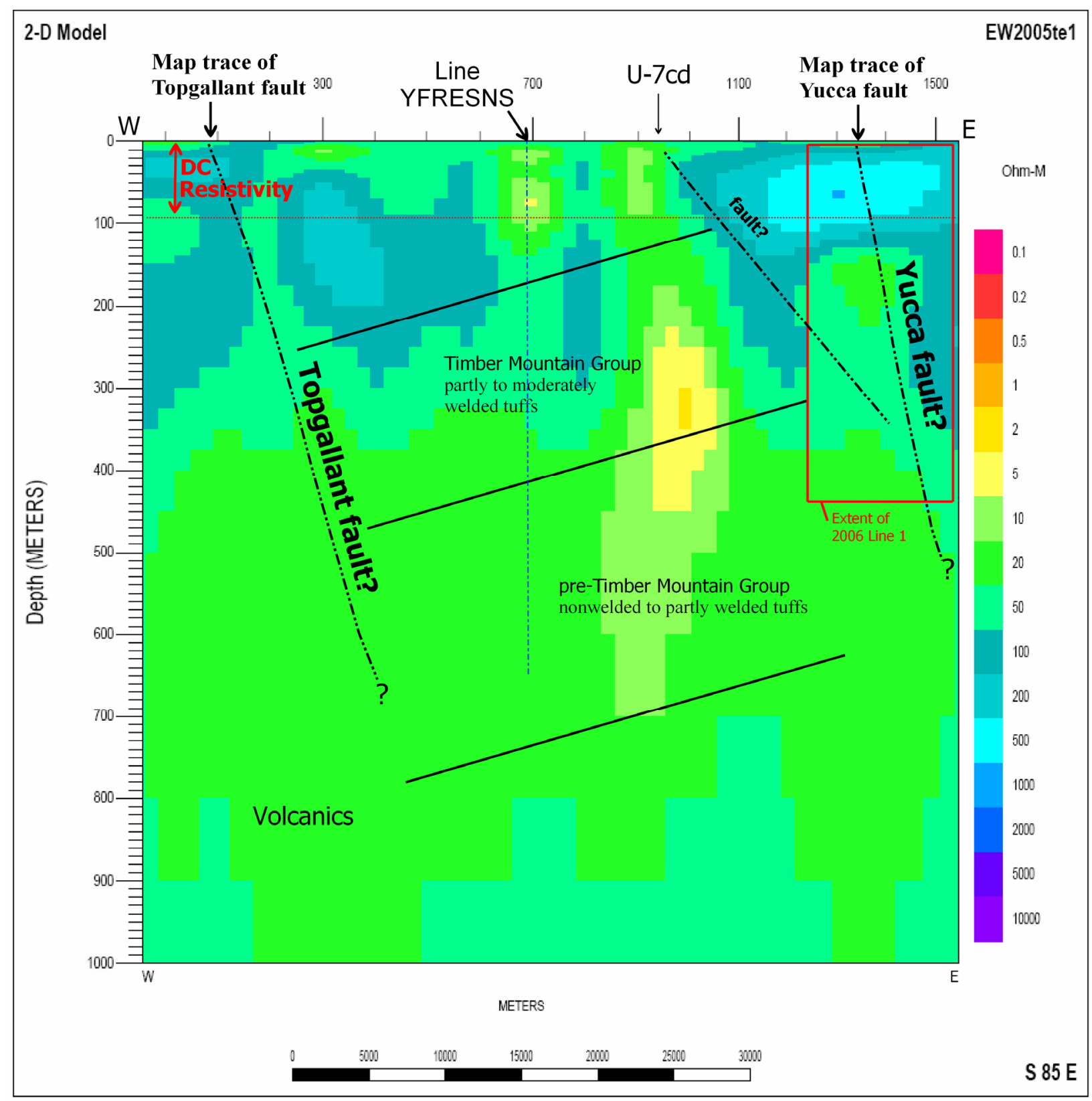

Figure 12. Two-dimensional AMT inversion modeling results for the TE mode on line YFRESEW. Line YFRESNS (fig. 11), which crosses this line at approximately 690 meters along the traverse, presents a similar resistivity-depth section at 240 meters along that traverse. 


\section{Field Effort}

The AMT results for data acquired in 2006 are presented in figures 13 through 16 . As with the DC resistivity modeling, the results for AMT Lines 1 and 2 near the southern drill hole U-7cd are presented first followed by results from Lines 3 and 4 which were located near the northern drill hole, U-2gj.

\section{Near U-7cd - Lines 1 and 2}

The AMT results for Line 1, presented in figure 13, compared with the DC resistivity results shown in figure 5, indicate several subsurface geologic contacts that may possibly be faults. As with the DC resistivity surveys, these survey traverses progressed from west to east (left to right in the figures). While there is a rapid change in the surface topography at the location of the Yucca fault escarpment that is approximately located near station 110 in figure 13 , the noted topographic exposure is only on the scale of about $4 \mathrm{~m}$. Given the scale of figure 13 (down to $600 \mathrm{~m}$ ), such a small change in topography is not very evident.

The AMT results indicate several changes in conductivity along the line. One occurs at a distance of approximately $100 \mathrm{~m}$ along the traverse (near station 110) which corresponds with the surface expression of the Yucca fault. Other possible faults may be present at distances approximately $170 \mathrm{~m}$ (under station 117) and $210 \mathrm{~m}$ (station 121). Another fault, which is not marked in the figure, may be present at approximately 20 to $30 \mathrm{~m}$ along the line (under stations 102 and 103).

The AMT 2-D inversion results for Line 2, presented in figure 14, show a resistivity discontinuity at approximately $100 \mathrm{~m}$ along the line (under station 210 ) that may be another expression of Yucca fault. Another smaller fault may exist just to the left of the conductive zone 
at approximately 140 to $150 \mathrm{~m}$ along the line (under stations 214 and 215) and another small fault under station 218 .

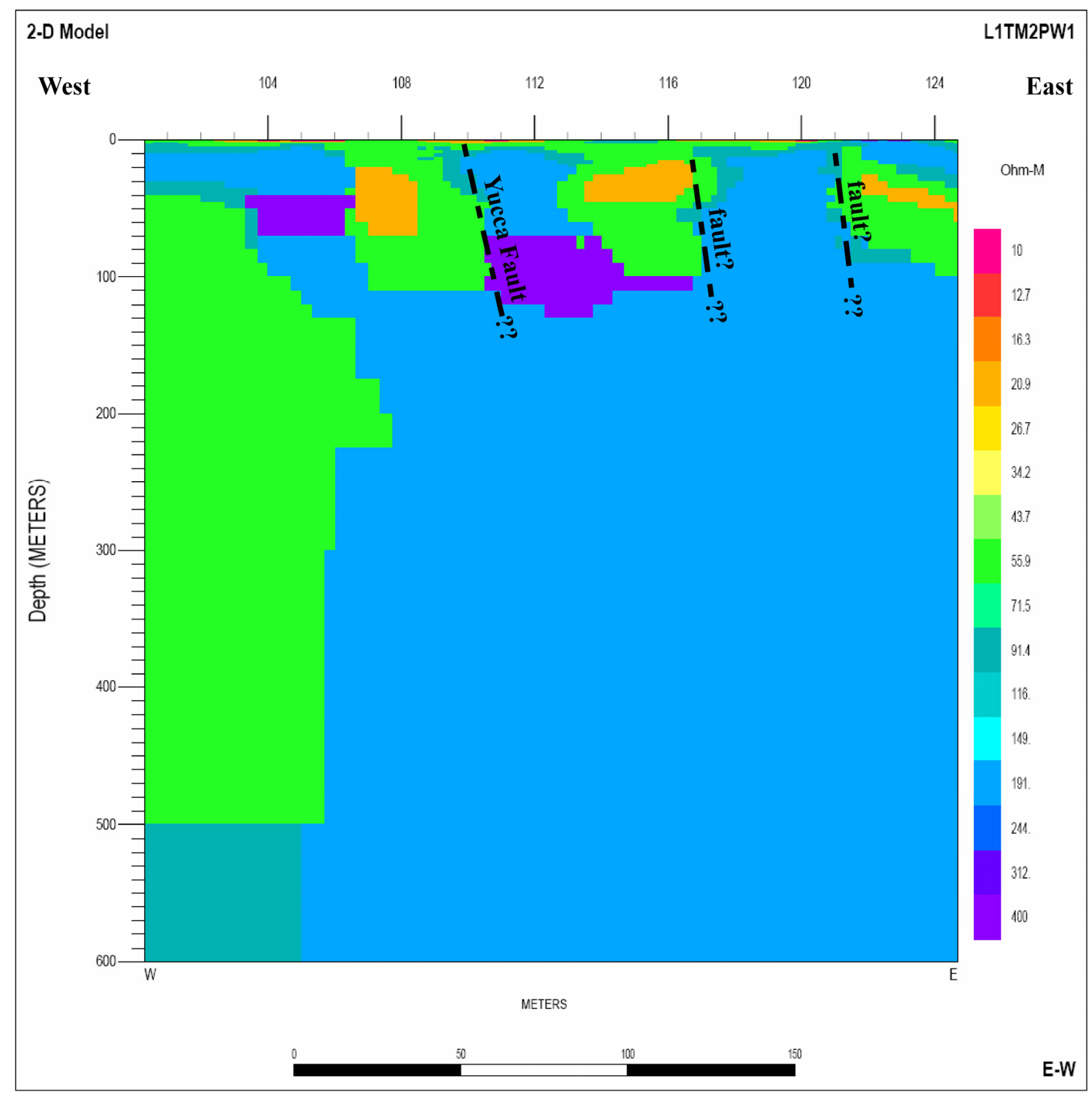

Figure 13. AMT two-diminsional inversion modeling results for Line 1 (fig. 2) of 2006 field effort at the Nevada Test Site, Nevada. 


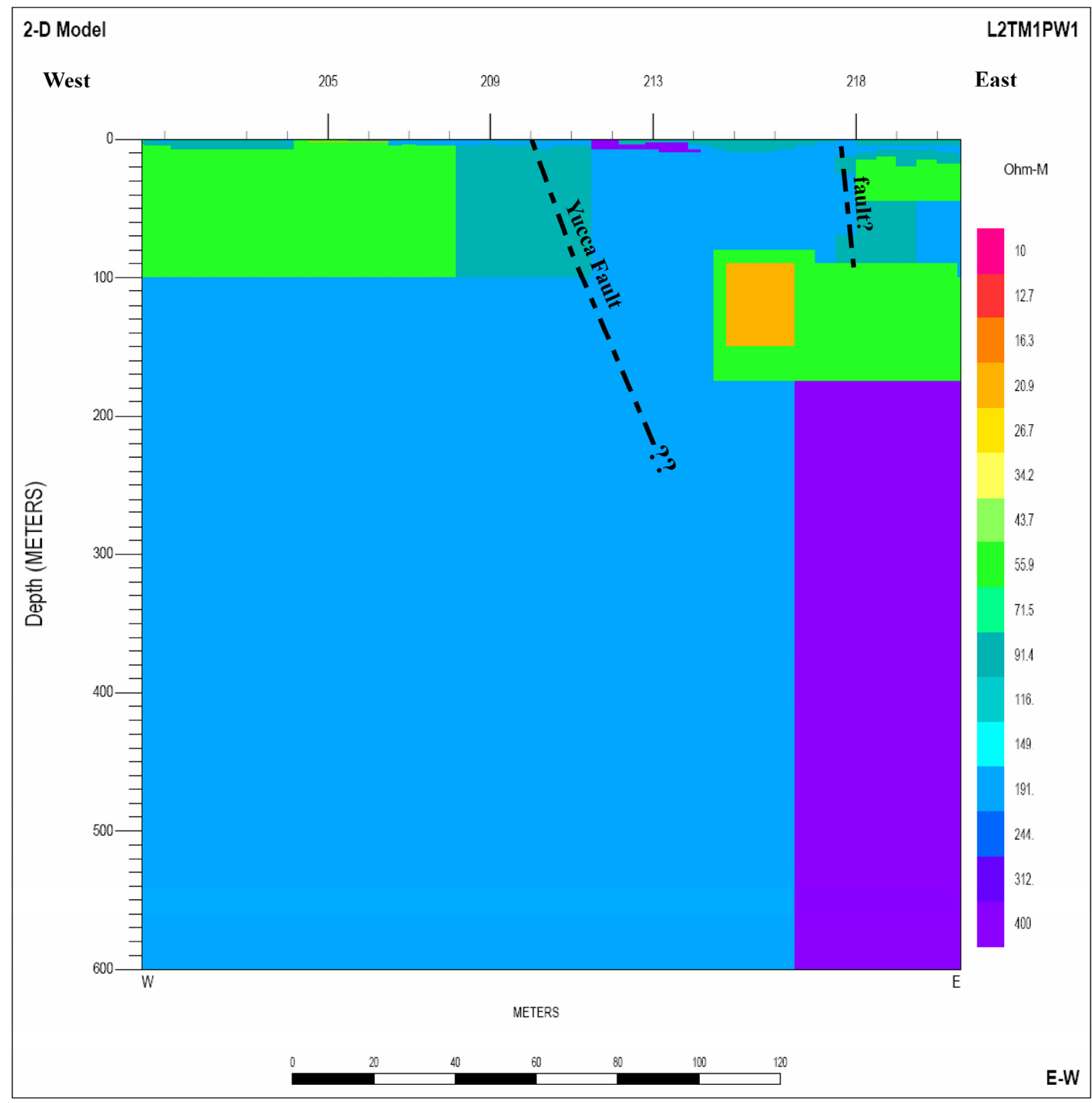

Figure 14. AMT two-dimensional inversion modeling results for Line 2 (fig. 2) of 2006 field effort at the Nevada Test Site, Nevada.

A conclusion that may be drawn from a comparison between the DC resistivity results shown in figures 5 and 6 and those for the AMT in figures 13 and 14 is that the AMT technique does not have as high a lateral resolution as the DC technique. This is not a total surprise since the DC electrode spacing was $2 \mathrm{~m}$ between spacings and the AMT station spacing was $10 \mathrm{~m}$, 
with one set of magnetic field readings used for two adjacent stations. While this was not an unusual setup for AMT measurements because the magnetic fields are known to vary slowly over a small area, it still indicates a limitation of the AMT technique to delineate small changes in resistivity over a small area.

\section{Near U-2gj — Lines 3 and 4}

As described above, Line 3 is located south of drill hole U-2gj (fig. 2) in the northern end of Yucca Flat basin. The Line 3 AMT inversion results (fig. 15) indicate slight conductivity contrasts (from $250 \mathrm{ohm}-\mathrm{m}$ to $400 \mathrm{ohm}-\mathrm{m}$ ) in the subsurface at shallow depths at similar locations to those observed in the DC resistivity modeling (fig. 7). A few more small faults are inferred along the AMT profile than along the DC resistivity profile. Along the line, these small faults are located at $22 \mathrm{~m}$ (station 302), $52 \mathrm{~m}$ (station 305), $78 \mathrm{~m}$ (station 308), $103 \mathrm{~m}$ (station 310), $126 \mathrm{~m}$ (station 313), $137 \mathrm{~m}$ (station 314), $159 \mathrm{~m}$ (station 316), and at $176 \mathrm{~m}$ (station 318).

Line 4 is located just north of drill hole U-2gj (fig. 2). As with the DC resistivity inversion results for Line 4 (fig. 8), the AMT inversion results (fig. 16) do not present a very great resistivity contrast in the subsurface. Possible faults are located at $15 \mathrm{~m}$ (between stations 401 and 402), $34 \mathrm{~m}$ (between stations 403 and 404), and $182 \mathrm{~m}$ along the traverse (between stations 418 and 419). Note that there is no indication, in this AMT section, of a fault under station 410 that is noted in the trench on the surface at this site. 


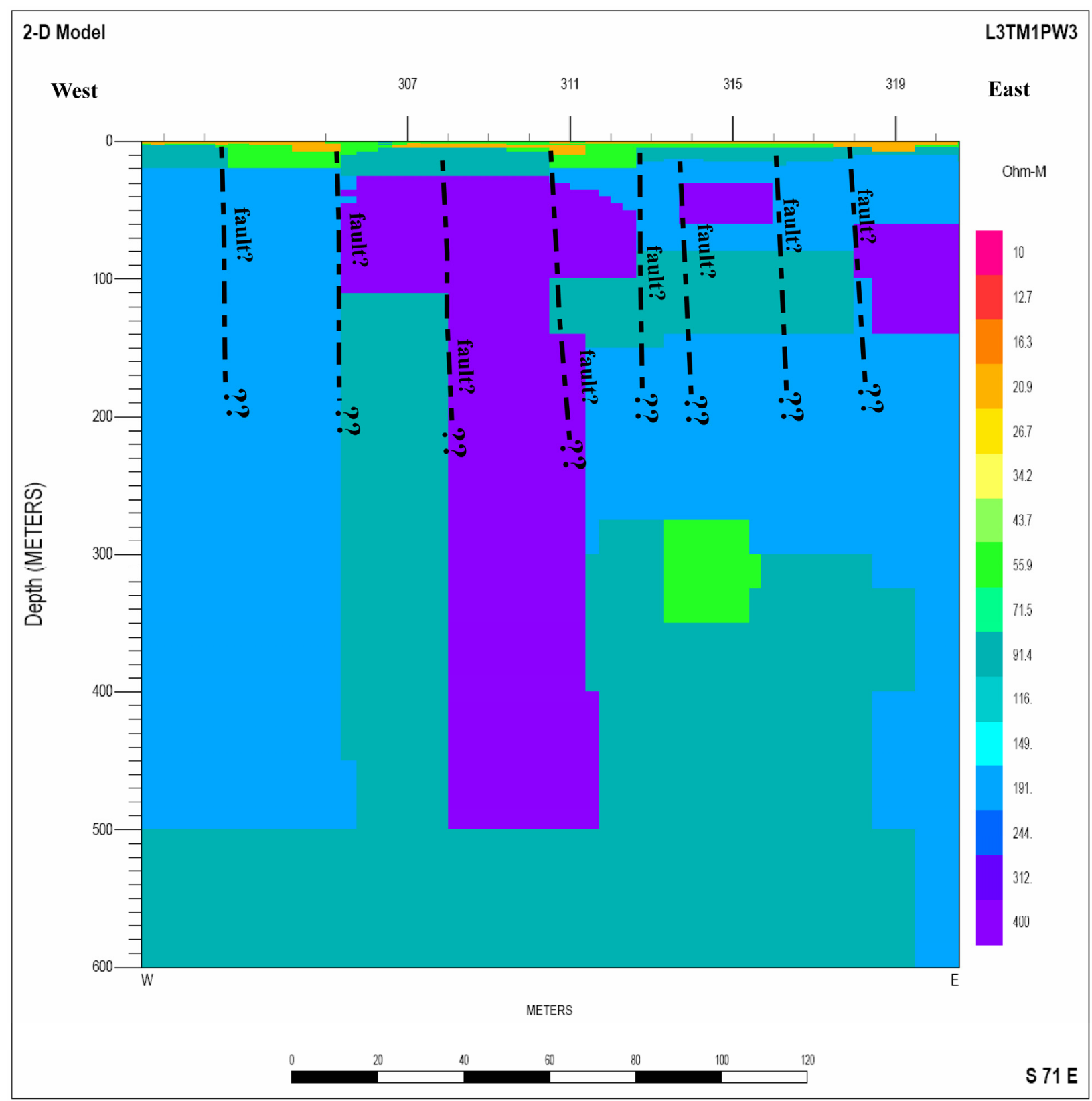

Figure 15. AMT two-dimensional inversion modeling results for Line 3 (fig. 2) of 2006 field effort at the Nevada Test Site, Nevada. 


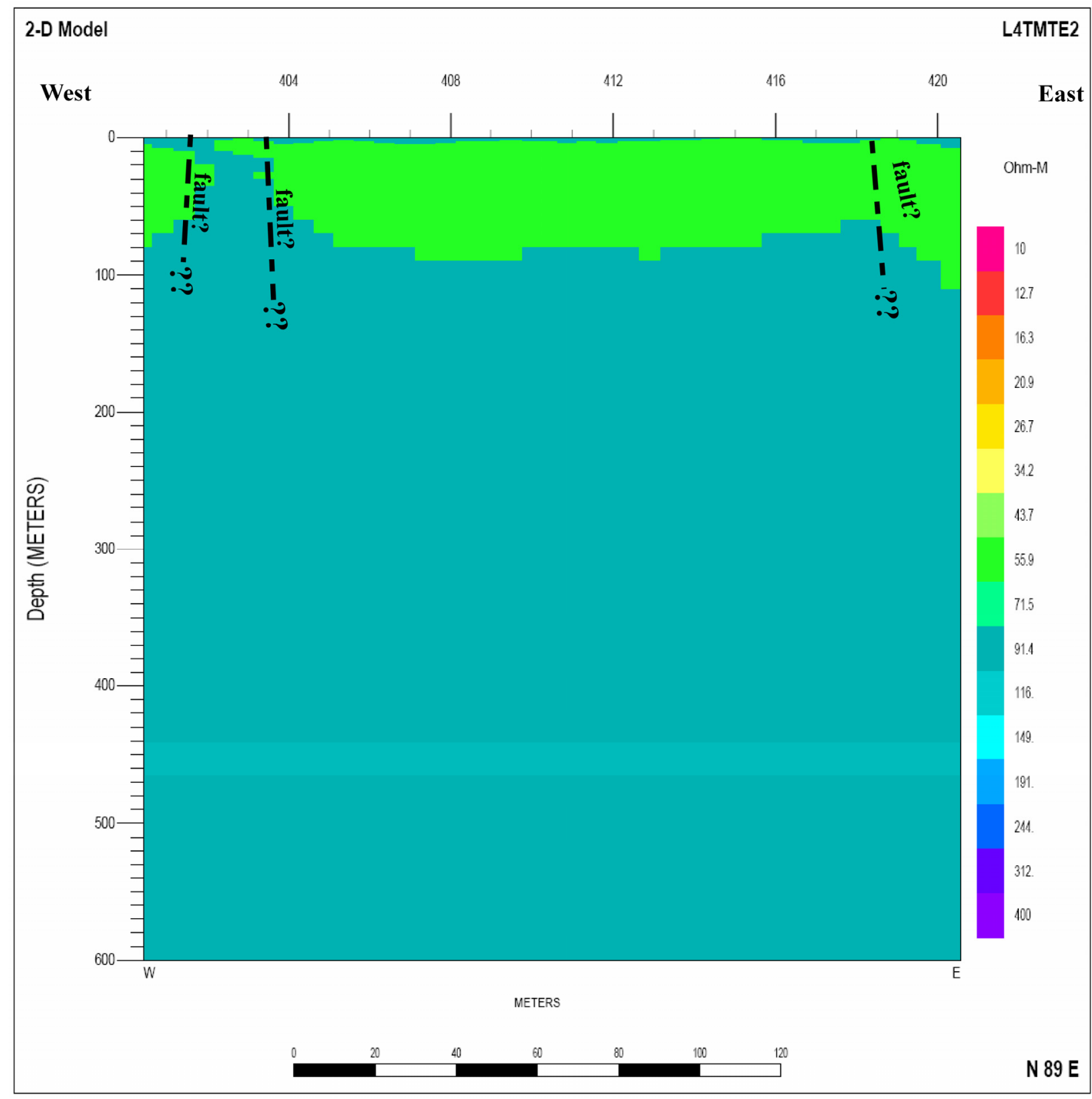

Figure 16. AMT two-dimensional inversion modeling results for Line 4 (fig. 2) of 2006 field effort at the Nevada Test Site, Nevada. 


\section{Vertical Gradient Magnetic Field Results}

As previously described a magnetic field survey was conducted along lines YFRESEW and YFRESNS to check for a magnetic susceptibility contrast across the traversed faults. The magnetic field survey results presented in figure 17 have been corrected for diurnal variations and indicate changes in the magnetic field up to 200 nanoteslas (nT) across Yucca fault on the eastern end of line YFRESEW and, possibly, up to $50 \mathrm{nT}$ in the vicinity of Topgallant fault on the western end, though this amplitude variation is not very clear. The large high- and lowamplitude signals in the vicinity of easting 584600 are related to proximity to the U-7cd tower and the associated buildings and cables on top of and underneath the ground in that area. The vertical gradient of the measured magnetic fields did not show any large changes across the faults, likely due to the size of the structures involved. 


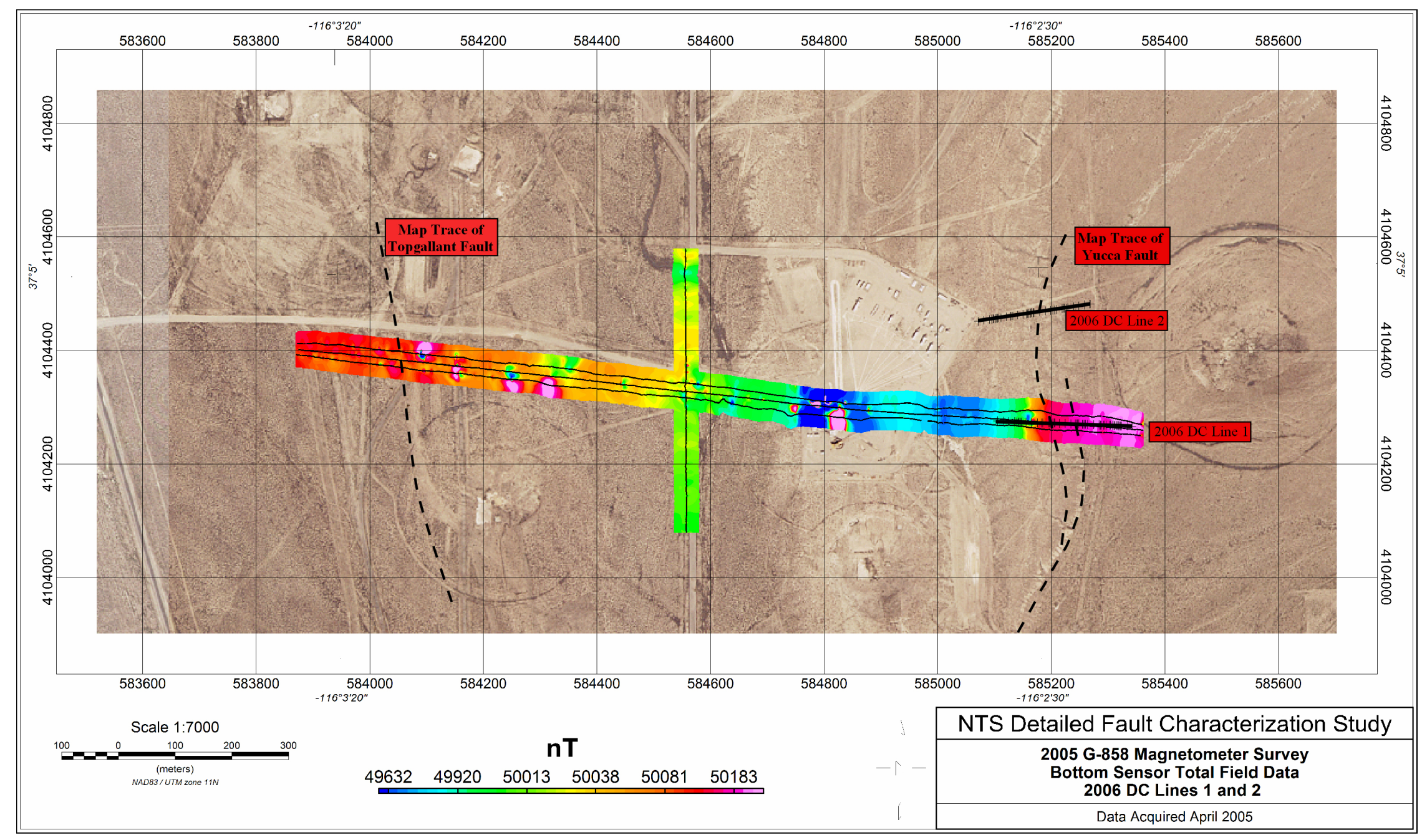

Figure 17. Bottom sensor total magnetic field data near drill hole U-7cd, Yucca Flat, Nevada Test Site, Nevada. Location of drill hole is near easting 584800 along the line of the east-west profile. DC resistivity lines 1 and 2 are indicated, as are the map traces of Yucca fault and Topgallant fault. [nT, nanoteslas] 


\section{Discussion}

The goal of the present investigation is to develop, through geophysical study, an understanding of the geometry and architecture of fault zones at various scales in Yucca Flat. To this end, geophysical profiles were conducted across faults with various lengths and magnitude of offset. Line YFRESEW and Lines 1 and 2 (fig. 2) were collected across Yucca fault, a mature fault with about $300 \mathrm{~m}$ of displacement (Ferguson and others, 1988) and one of the major structures in Yucca Flat. Line 3 data were collected across a small mapped fault (Slate and others, 1999) to the south of drill hole U-2gj (fig. 2). Geologic cross-sections across the northern part of Yucca Flat that were tied to well and seismic data (IT Corporation, 1996) portray this small fault as an antithetic splay with about $30 \mathrm{~m}$ of west-side-down offset in the hanging wall of the Carpetbag fault. Line 4 data were collected across the northern projection of the same fault trace in an area where there are no mapped surface faults except for that uncovered in the trench at center of the line.

\section{Geophysical Response Related to Varying Fault Offset}

The location and magnitude of offset along major faults such as Yucca fault were previously determined by integration of results from gravity studies (Ferguson and others, 1988;

Phelps and others, 1999; Phelps and McKee, 1999), regional magnetotelluric profiles (Asch and others, 2006), surface mapping (Slate and others, 1999; Grasso, 2001), abundant drill-hole data (Covington and Berger, 1997), and previous subsurface interpretations (IT Corporation, 1996; Bechtel Nevada, 2006). Fault offset along Yucca fault is suggested from the AMT models (figs. 9,13 , and 14) as a result of juxtaposition of lithologic units, such as alluvial fill and partly welded ash-flow tuff, which have differing resistivity. Geologic cross sections across the central 
part of Yucca Flat that were tied to well and seismic data (IT Corporation, 1996) portray Yucca fault as two subparallel strands; this geometry is supported by the detailed AMT data (figs. 13 and 14). The DC resistivity data across Yucca fault show clear offsets at even in the shallow subsurface where lithologic contrast across the fault would be expected to be low in the alluvium (figs. 5 and 6).

Geophysical profiles across the small mapped fault (Slate and others, 1999) to the south of drill hole U-2gj portray a complicated response interpreted to be the result of several small faults (figs. 7 and 15). Relatively slight conductivity contrasts indicate that the faulting is likely within the same or closely related lithological unit, consistent with the relatively small amount of offset expected. The northernmost line (Line 4) shows the smallest conductivity contrasts, and only a few limited faults can be inferred (figs. 8 and 16).

\section{Geophysical Response Related to Fault Zone Geometry and Architecture}

Field mapping and seismic studies have demonstrated that fault zones result from displacements along numerous discrete segments (Segall and Pollard, 1980; Stewart and Hancock, 1991). Fault segments tend to be linked together in map and cross-section view, but the overall geometry of the fault zone is more complex than a single planar feature. As fault displacement proceeds (either vertically or horizontally), segments may coalesce into a longer, geometrically simple feature (Segall and Pollard, 1980; Peacock and Sanderson, 1991). Additionally, most faults can be described as having an internal architecture (Caine and others, 1996; Kim and others, 2004) consisting of the following general elements: (1) a protolith of relatively undamaged rock, (2) a damage zone of fractured and brecciated fault rock, and (3) a fault core composed of gouge or cataclastic rock. The width and distribution of fault rocks in a fault zone are known to be related to the type and magnitude of fault displacement (Hull, 1988), 
rock type, geometry of the fault-zone segments, and the physical environment (Sibson, 1986). Geophysical profiles were conducted at a variety of scales in an attempt to characterize individual fault segments and to identify the extent of damage zones associated with fault offset.

Yucca fault has a generally north-south surface trace but is broadly sinuous (fig. 1) along its 32-km length. Subsequent to underground nuclear testing near the fault, large fractures formed in the alluvium along Yucca fault where no fractures were noted prior to testing (Barosh, 1968). Mapping of surface effects in Yucca Flat (Grasso, 2001) reveals a variety of features including collapse sinks, craters, cracks, fractures, faults, and pressure ridges, many of which are related to postexplosion collapse and expansion. However, the fractures along and near the trace of Yucca fault (fig. 18) are interpreted to be the surface expression of faults in the alluvial fill, these faults being the result of induced reactivation of an older, much larger bedrock feature (fault structure?) (Barosh, 1968). Topographically, the surface expression of the fault is generally an eastward-facing scarp about $3 \mathrm{~m}$ high. The fractures along Yucca fault form an en-echelon pattern along the fault with curving, northwest and northeast trends (fig. 18). These fractures appear to represent linked fault segments that initiated in the alluvium above the deeper bedrock fault.

2006 AMT Lines 1 and 2 were collected across the surface scarp of Yucca fault (fig. 19) near a point where two fault segments are linked. Line 1 is just north of a northeast-striking fault segment; Line 2 is along a segment that strikes north-northwest. The AMT results (fig. 19) are consistent with the location and complexity of the surface trace, including the presence of multiple fault surfaces. The relatively gentle dips of the fault strands in Line 2 (fig. 19) may be the result of curved, low-angle relay structures that transfer displacement between fault segments. Alternatively, the far resistive block east of Yucca fault at the eastern end of Line 2 may be seeing the collapse effects of a moderate-sized crater to the east of the profile. 


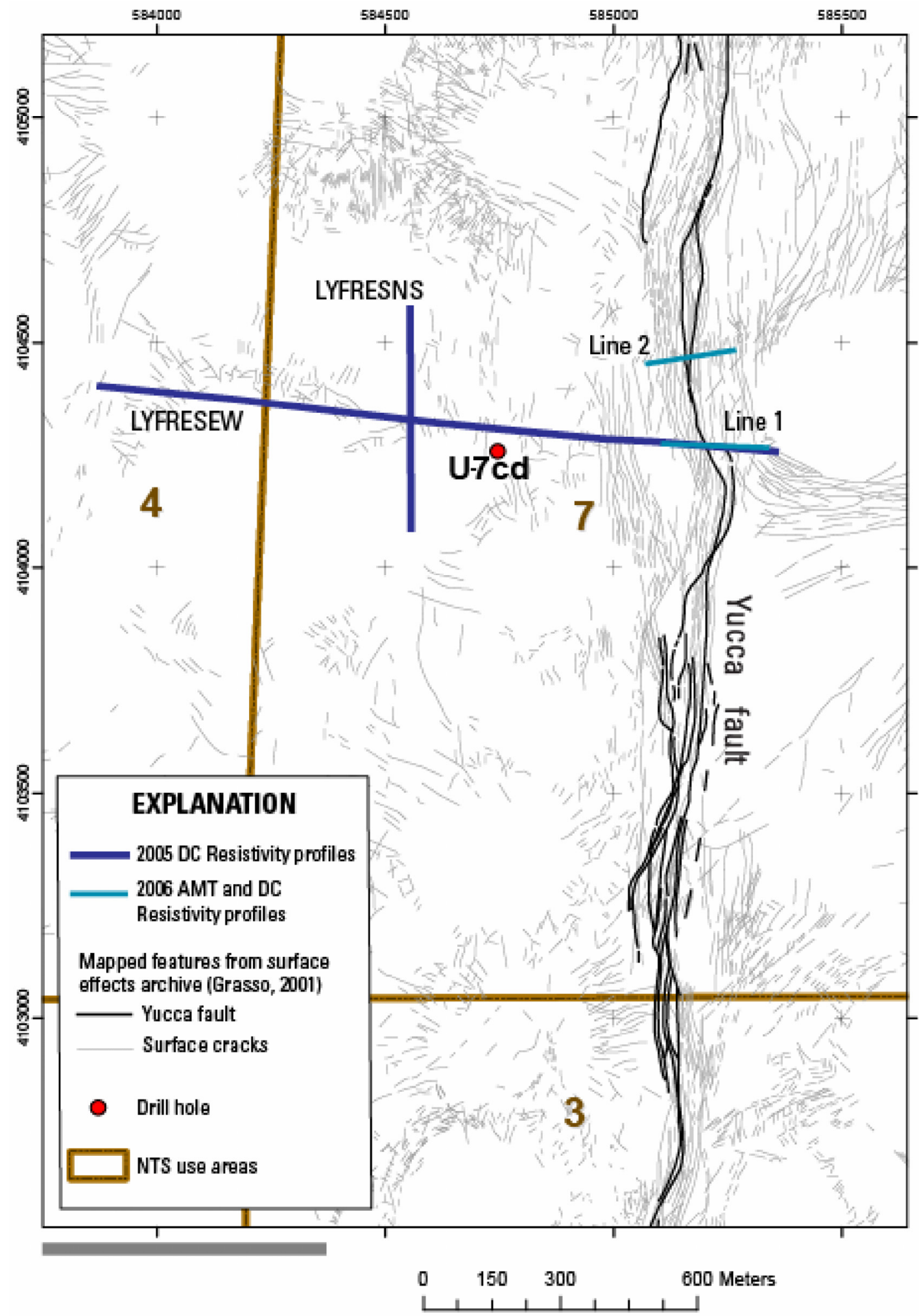

Figure 18. Map of Yucca fault and surface effects near drill hole U-7cd on Yucca Flat at the Nevada Test Site, Nevada. [AMT, audio magnetotelluric; DC, direct current; NTS, Nevada Test Site]. 


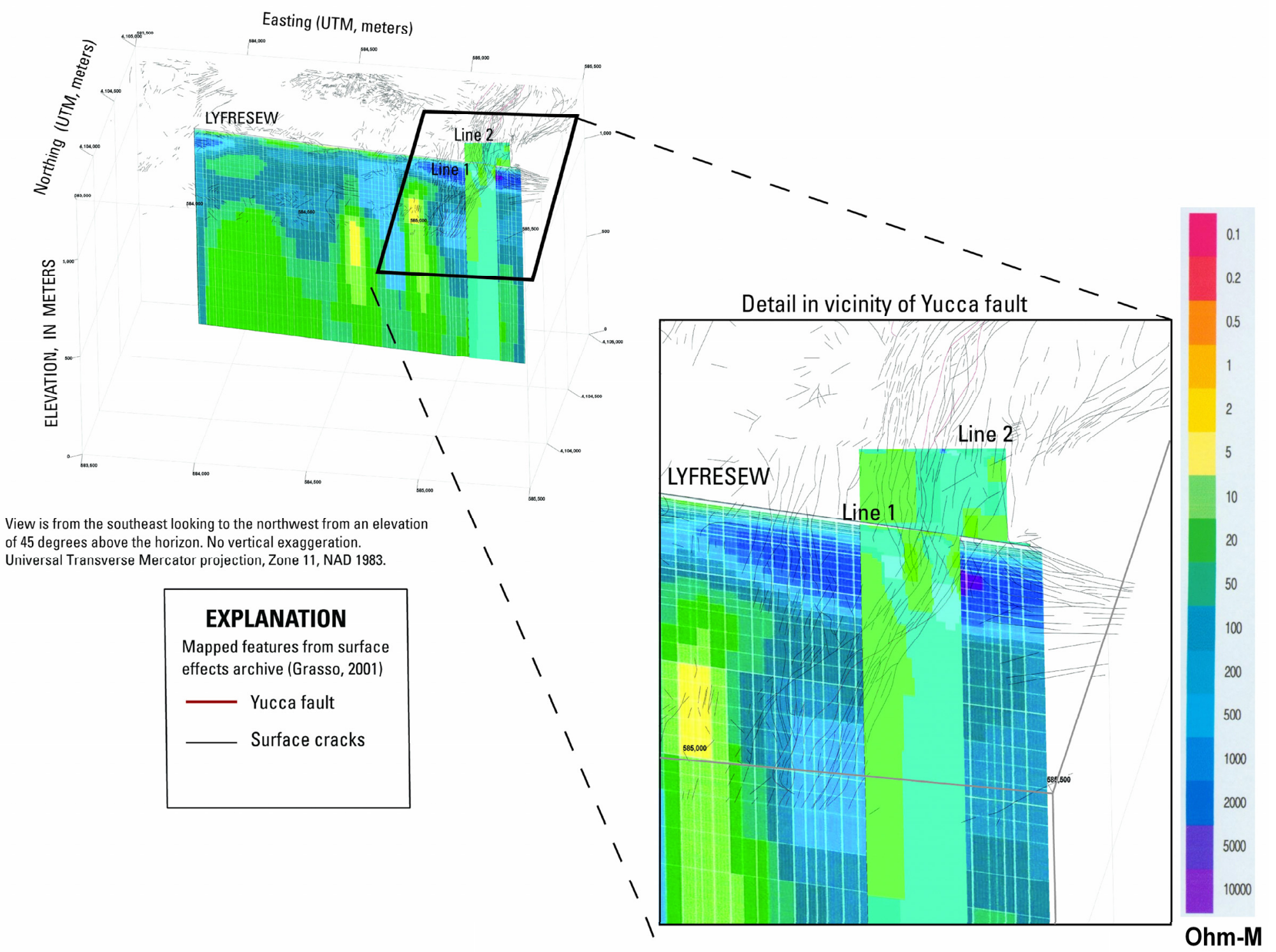

Figure 19. Schematic three-dimensional perspective view of AMT profiles, Yucca fault and surface effects near drill hole U-7cd on Yucca Flat at the Nevada Test Site, Nevada. [Ohm-M, ohm-meters] 
Surface fractures in alluvium that formed as a result of underground nuclear tests originally extended to a depth of as much as $30 \mathrm{~m}$; most were widest at the surface and narrowed with depth (Carr, 1965). These fractures have largely filled in over the past decades and can no longer be seen. However, the DC resistivity profiles still appear to respond to the presence of these relief fracture zones, presumably because of the differing resistivity of the alluvium and the fracture-filling material. When the DC resistivity profiles are compared with the surface-effects map (fig. 20), there appears to be a nearly one-to-one correspondence; each surface feature appears to correspond to a change in resistivity along the profile. Irregular, complex variations in resistivity are present within about $20 \mathrm{~m}$ of each fault plane (figs. 5 and 6). This may represent the extent of fault-related damage associated with each fault trace. While this may be the case in the upper $10 \mathrm{~m}$ for $5-\mathrm{m}$ electrode spacings, the response deeper than $10 \mathrm{~m}$ could represent a loss of resolution during the inversion, resulting in inversion artifacts. Overlap and steps between adjacent fault traces may increase the width of the disturbed zone to as much as $50 \mathrm{~m}$, as seen on the surface-effects map (fig. 18). Changes in conductivity in the welded volcanic layers as Yucca fault is approached in AMT line YFRESEW (fig. 9) may also be the result of footwall damage adjacent to the fault.

DC resistivity data from the northern geophysical profiles near drill hole $\mathrm{U}-2 \mathrm{gj}$ again are consistent with the surface-effects map (fig. 21), but the resistivity structure is much less variable adjacent to each fault, indicating that the fault-associated damage may be much narrower or less pronounced because of fracture-filling material that has an electrical resistivity that is similar to the alluvium overburden. 


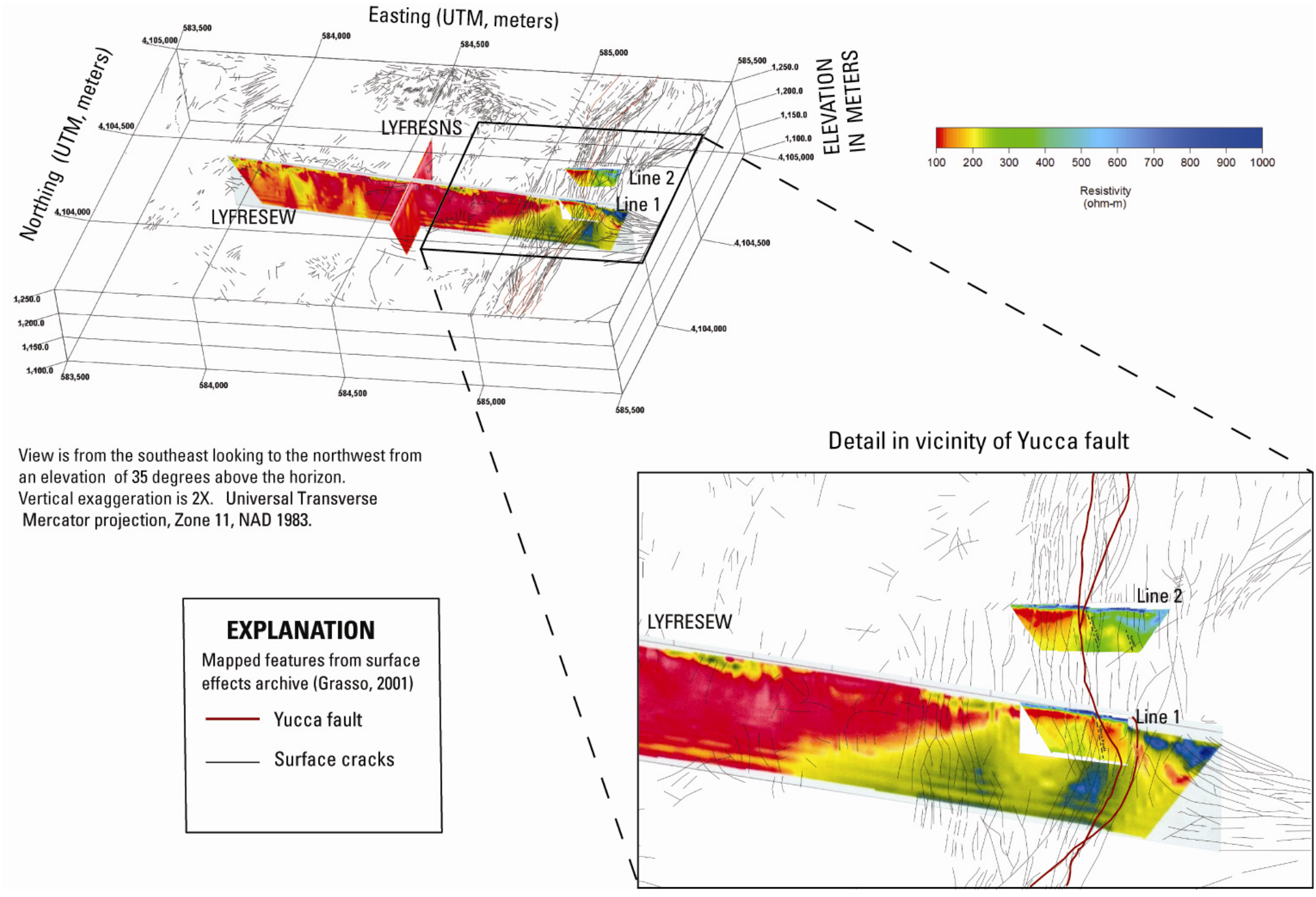

Figure 20. Three-dimensional perspective view of DC resistivity profiles, the Yucca fault, and surface effects near drill hole U-7cd. [ohm-m, ohm-meters] 


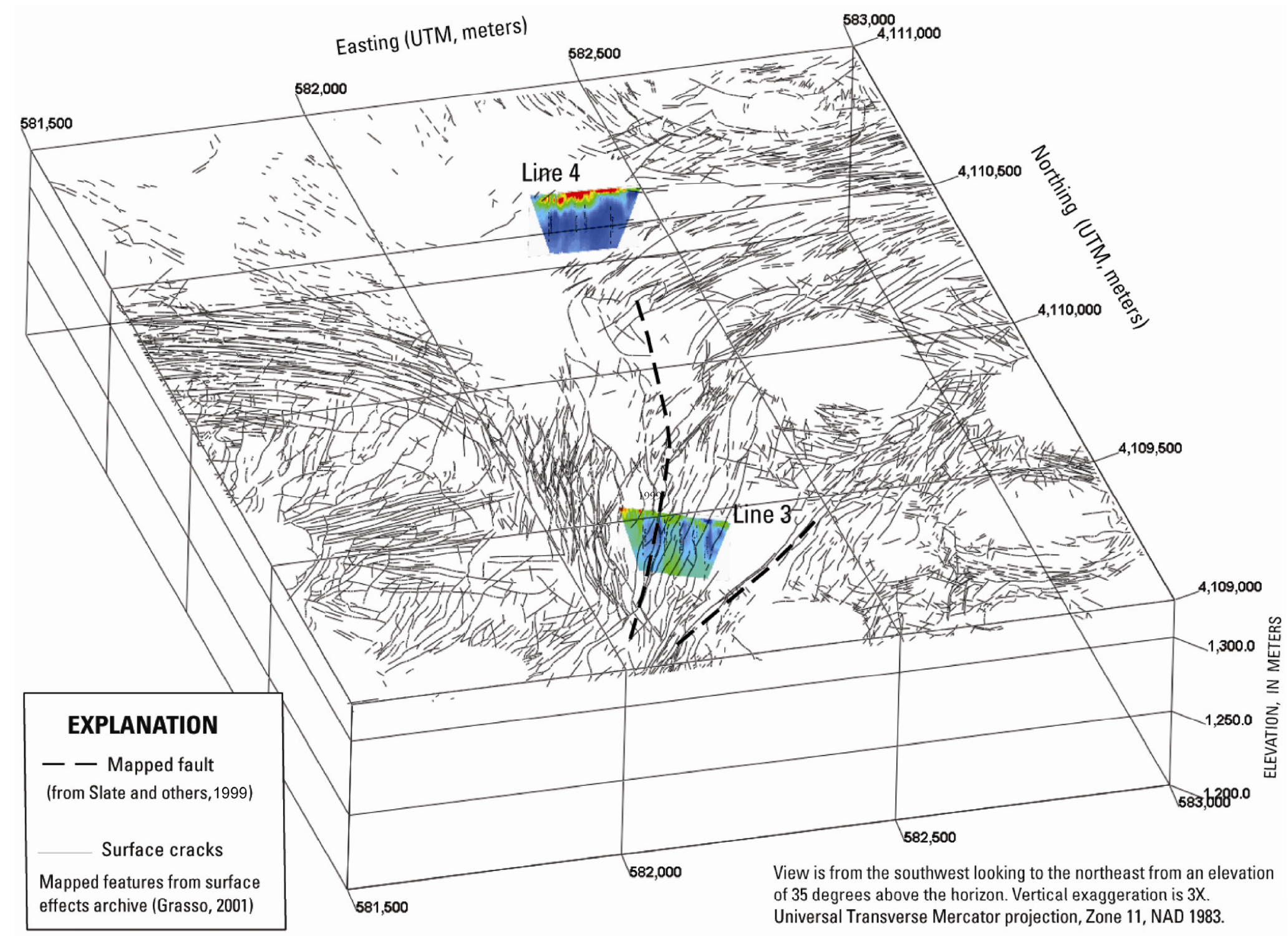

Figure 21. Three-dimensional perspective view of DC resistivity profiles and surface effects near drill-hole U-2gj. [UTM, Universal Transverse Mercator] 


\section{Conclusions}

Detailed geophysical investigations near fault zones at Yucca Flat have revealed geophysical responses at a variety of scales of observation. At the most general scale, MT data provide information on the location of deeper crustal structures and general information on the attitude of the structure. AMT data provide a higher resolution set of observations confined to within about $1 \mathrm{~km}$ of the surface. These data allow for the delineation of multiple fault strands, understanding geometric relations at fault stopovers and intersections. The AMT data are best interpreted in areas with abundant drill-hole control because of the high degree of variability in lithology in the upper $1 \mathrm{~km}$ of section at Yucca Flat. DC resistivity data provide higher resolution imaging of the uppermost portions of fault zones than the AMT data and show a high degree of correspondence with fault-related surface fracturing. The magnetic field data indicated a clear change across the Yucca fault but not as strong a change across the Topgallant fault. Additional insights into the nature of faulting at Yucca Flat could be gained through threedimensional AMT or DC resistivity surveys that might capture along-strike variations in fault characteristics.

While one of the goals of this study was to determine if the faults and fractures could be conduits or barriers to ground-water flow, the acquired data do not indicate one way or another if the faults studied would hinder or allow flow of ground water. This may be a function of when the data were acquired (early summer). Additional data collection during late winter or early spring, when more ground water was flowing in the near surface, could help resolve this issue. Any new electrically conductive or resistive anomalous zones could be investigated with shallow boreholes and the physical properties of these zones determined. 


\section{References Cited}

Advanced Geosciences, Inc., 2003, The SuperSting with Swift automatic resistivity and IP system instruction manual: Advanced Geosciences, Inc., Austin, Texas, 73 p.

Advanced Geosciences, Inc., 2006, Instruction manual for EarthImager 2D version 2.1.6Resistivity and IP inversion software: Advanced Geosciences, Inc., Austin, Texas, 122 p. Asch, T.H., Rodriguez, B.D., Sampson, J.A., Wallin, E.L., and Williams, J.M., 2006, Deep resistivity structure of Yucca Flat, Nevada Test Site, Nevada: U.S. Geological Survey OpenFile Report 2006-1261, 86 p.

Barosh, P.J., 1968, Relationship of explosion-produced fracture patterns to geologic structure in Yucca Flat, Nevada Test Site, in Eckel, E. B., ed., Nevada Test Site: Geological Society of America Memoir 110, p. 199-217.

Bechtel Nevada, 2006, A hydrostratigraphic model and alternatives for the groundwater flow and contaminant transport model of Corrective Action Unit 97-Yucca Flat-Climax Mine, Lincoln and Nye Counties, Nevada: U.S. Department of Energy Report DOE/NV/11718-1119, 288 p.

Bendat, J.S., and Piersol, A.G., 1971, Random data-analysis and measurement procedures: New York, Wiley Interscience, 407 p.

Byers, F.M., Jr., Carr, W.J., Orkild, P.P., Quinlivan, W.D., and Sargent, K.A., 1976, Volcanic suites and related cauldrons of the Timber Mountain-Oasis Valley caldera complex, southern Nevada: U.S. Geological Survey Professional Paper 919, 70 p.

Caine, J.S., Evans, J.P., and Forster, C.B., 1996, Fault zone architecture and permeability structure: Geology, v. 24, p. 1025-1028.

Carothers, J.E., 1995, Caging the dragon-The containment of underground nuclear explosions: U.S. Department of Energy Report DOE/NV-388, Defense Nuclear Agency Report DNA-TR95-74, $726 \mathrm{p}$. 
Carr, W. J., 1965, Preliminary results of subsurface investigation of fractures in Yucca Flat, Nevada Test Site: U.S. Geological Survey Technical Letter Yucca-57, 15 p.

Caskey, S.J., and Schweickert, R.A., 1992, Mesozoic deformation in the Nevada Test Site and vicinity_Framework of the Cordilleran Fold and Thrust Belt and Tertiary extension north of Las Vegas Valley: Tectonics, v. 11, p. 1314-1331.

Cole, J.C., Harris, A.G., and Wahl, R.R., 1997, Subcrop geologic map of pre-Tertiary rocks in the Yucca Flat and northern Frenchman Flat areas, Nevada Test Site, southern Nevada: U.S. Geological Survey Open-File Report 97-678, scale 1:48,000, 24 p.

Cole, J.C., and Cashman, P.H., 1999, Structural relationships of pre-Tertiary rocks in the Nevada Test Site region, southern Nevada: U.S. Geological Survey Professional Paper 1607, 39 p.

Covington, H.R., and Berger, M.A., 1997, Catalogue of lithologic and stratigraphic information from drill holes on the Nevada Test Site and environs: U.S. Geological Survey Open-File Report 97-139, 221 p.

Dobrin, M.D., and Savit, C.H., 1988, Introduction to geophysical prospecting (4th ed.): New York, McGraw-Hill, 867 p.

Department of Energy UGTA Fact Sheet, 2003, Underground Test Area Fact Sheet: DOE/NV915, August 2003, 2 p.

Eberhart-Phillips, Donna, Stanley, W.D., Rodriguez, B.D., and Lutter, W.J., 1995, Surface seismic and electrical methods to detect fluids related to faulting: Journal of Geophysical Research, v. 100, no. B7, p. 12919-12936.

Egbert, G.D., 1997, Robust multiple station magnetotelluric data processing: Geophysics Journal International, 130, p. 475-496.

Ekren, E.B., 1968, Geological setting of Nevada Test Site and Nellis Air Force Range, in Eckel, E.B., ed., Nevada Test Site: Geological Society of America, Memoir 110, p. 11-20. 
EMI, 1996, MT-1 magnetotelluric system operation manual, version 3.2: Richmond, Calif., ElectroMagnetic Instruments, Inc., 220 p.

EMI, 2002, MT24/LF System Operation and Maintenance Manual, version 1.0: Richmond, Calif., ElectroMagnetic Instruments, Inc., 72 p.

Ferguson, J.F., Felch, R.N., Aiken, C.L.V., Oldow, J.S., and Dockery, Holly, 1988, Models of the Bouguer gravity and geologic structure at Yucca Flat, Nevada: Geophysics, v. 53, p. 231244.

Gamble, T.D., Goubau, W.M., and Clarke, J., 1979, Error analysis for remote reference magnetotellurics: Geophysics, v. 44, no. 5, p. 959-968.

Geotools, 1998, Geotools MT User's Guide: Geotools Corporation, a division of AOA Geophysics, 450 p.

Grasso, D.N., 2001, GIS surface effects archive of underground nuclear detonations conducted at Yucca Flat and Pahute Mesa, Nevada Test Site, Nevada: U.S. Geological Survey Open-File Report 2001-0272, 34 p., 1 plate, 1 CD-ROM.

Hinrichs, E.N., 1968, Geologic structure of the Yucca Flats area, Nevada, in Eckel, E.B., ed., Nevada Test Site: Geological Society of America Memoir 110, p. 239-246.

Hull, J., 1988, Thickness-displacement relationships for deformation zones: Journal of Structural Geology, v. 10, p. 431-435.

IT Corporation, 1996, Underground test area subproject phase I data analysis Task (Vol. I)— Regional geologic model data documentation package: Las Vegas, Nev., ITLV/10972-81, 407 p.

Keller, G.V., 1987, Rock and mineral properties, in Nabighian, M.N., ed., Electromagnetic methods in applied geophysics theory: Tulsa, Okla., Society of Exploration Geophysicists, v. 1, p. $13-51$. 
Keller, G.V., 1989, Electrical properties, in Carmichael, R.S., ed., Practical handbook of physical properties of rocks and minerals: Boca Raton, Fla., CRC Press, p. 359-427.

Kim, Y.-S., Peacock, D.C.P., and Sanderson, D.J., 2004, Fault damage zones: Journal of Structural Geology, v. 26, p. 503-517.

Mackie, Randall, Rieven, Shirley, and Rodi, William, 1997, Users manual and software documentation for two-dimensional inversion of magnetotelluric data: GEOTOOLS User's Guide RLM2DI Supplement, 10 .

Nelson, P.H., and Anderson, L.A., 1992, Physical properties of ash flow tuff from Yucca Mountain, Nevada: Journal of Geophysical Research, v. 97, no. B5, p. 823-6841.

Palacky, G.J., 1987, Resistivity characteristics of geologic targets, in Nabighian, M.N., ed., Electromagnetic methods in applied geophysics theory: Tulsa, Okla., Society of Exploration Geophysicists, v. 1, p. 53-129.

Peacock, D.C.P. and Sanderson, D.J., 1991, Displacements, segment linkage and relay ramps in normal fault zones: Journal of Structural Geology, v. 13, p. 721-733.

Phelps, G.A., and McKee, E.H., 1999, High-angle faults in the basement of Yucca Flat, Nevada Test Site, Nevada, based on analysis of a constrained gravity inversion surface: U.S. Geological Survey Open-File Report 99-383, 6 p.

Phelps, G.A., Langenheim, V.E., and Jachens, R.C., 1999, Thickness of Cenozoic deposits of Yucca Flat inferred from gravity data, Nevada Test Site, Nevada: U.S. Geological Survey Open-File Report 99-310, 33 p.

Reddy, I.K., Rankin, David, and Phillips, R.J., 1977, Three-dimensional modelling in magnetotelluric and magnetic variational sounding: Geophysics Journal of the Royal Astronomical Society, v. 51, p. 313-325. 
Rodi, William, and Mackie, R.L., 2001, Nonlinear conjugate gradients algorithm for 2-D magnetotelluric inversion: Geophysics, v. 66, no. 1, p 174-187.

Sawyer, D.A., Fleck, R.J., Lanphere, M.A., Warren, R.G., Broxton, D.E., and Hudson, M.R., 1994, Episodic caldera volcanism in the Miocene southwestern Nevada volcanic fieldRevised stratigraphic framework, ${ }^{40} \mathrm{Ar} r^{39} \mathrm{Ar}$ geochronology, and implications for magmatism and extension: Geological Society of America Bulletin, v. 106, p. 1304-1318.

Segall, P. and Pollard, D., 1980, Mechanics of discontinuous faults: Journal of Geophysical Research, v. 85, p. 555-568.

Sibson, R.H., 1986, Brecciation processes in fault zones—Inferences from earthquake rupturing: Pure and Applied Geophysics ( PAGEOPH ), v. 124, p. 107-125.

Slate, J.L., Berry, M.E., Rowley, P.D., Fridrich, C.J., Morgan, K.S., Workman, J.B., Young, O.D., Dixon, G.L., Williams, V.S., McKee, E.H., Ponce, D.A., Hildenbrand, T.G., Swadley, W.C., Lundstrom, S.C., Ekren, E.B., Warren, R.G., Cole, J.C., Fleck, R.J., Lanphere, M.A., Sawyer, D.A., Minor, S.A., Grunwald, D.J., Laczniak, R.J., Menges, C.M., Yount, J.C., and Jayko, A.S., 1999, Digital geologic map of the Nevada Test Site and vicinity, Nye, Lincoln, and Clark Counties, Nevada, and Inyo County, California: U.S. Geological Survey Open-File Report 1999-554A, 54 p., 2 pl., scale 1:120,000, accessed at http://pubs.usgs.gov/of/1999/ofr99-0554/.

Sternberg, B.K., Washburne, J.C., and Pellerin, Louise, 1988, Correction for the static shift in magnetotellurics using transient electromagnetic soundings: Geophysics, v. 53, p. 1459-1468.

Stewart, I. and Hancock, P.L., 1991, Scales of structural heterogeneity within neotectonic normal fault zones in the Aegean region: Journal of Structural Geology, v. 13, p. 191-204. 
Swadley, W.C., and Hoover, D.L., 1990. Geologic map of the surficial deposits of the Yucca Flat area, Nye County, Nevada: U.S. Geological Survey Miscellaneous Investigation Series Map I2047, scale 1:48,000.

U.S. Department of Energy, 2000, United States nuclear tests, July 1945 through September 1992: U.S. Department of Energy, Nevada Operations Office, DOE/NV-209 (rev. 15), 162 p.

Vozoff, Keeva, 1972, The magnetotelluric method in the exploration of sedimentary basins:

Geophysics, v. 37, p. 980-141.

Vozoff, Keeva, 1991, The magnetotelluric method, in Nabighian, M.N., Electromagnetic methods in applied geophysics: Tulsa, Okla., Society of Exploration Geophysicists, v. 2, pt. B, p. 641-711.

Wannamaker, P.E., 1983, Resistivity structure of the northern Basin and Range: Geothermal Resources Council, Special Report no. 13, p. 345 - 361.

Wannamaker, P.E., Hohmann, G.W., and Ward, S.H., 1984, Magnetotelluric responses of threedimensional bodies in layered earths: Geophysics, v. 49, no. 9, p. 1517-1533.

Wannamaker, P.E., Stodt, J.A., and Rijo, L., 1987, PW2D— Finite element program for solution of magnetotelluric responses of two-dimensional earth resistivity structure, (User documentation): Earth Science Laboratory, University of Utah Research Institute, Salt Lake City, $40 \mathrm{p}$.

Winograd, I.J., and Thordarson, William, 1975, Hydrogeologic and hydrochemical framework, south-central Great Basin, Nevada-California, with special reference to the Nevada Test Site: U.S. Geological Survey Professional Paper 712-C, 126 p. 


\section{Appendix A - DC Resistivity Two-Dimensional (2-D) Modeling}

Figure A-1. 2-D robust inversion for 2005 line YFRESEW from 0 to $760 \mathrm{~m}$ west-east along the line with data misfit.

Figure A-2. 2-D robust inversion for 2005 line YFRESEW from 230 to 990 m west-east along the line with data misfit.

Figure A-3. 2-D robust inversion for 2005 line YFRESEW from 460 to 1,500 m westeast along the line with data misfit.

Figure A-4. 2-D robust inversion for 2005 line YFRESNS from 0 to $500 \mathrm{~m}$ north-south along the line with data misfit.

Figure A-5. 2-D robust inversion for 2006 line 1 from 0 to $240 \mathrm{~m}$ west-east along the line with data misfit.

Figure A-6. 2-D robust inversion for 2006 line 2 from 0 to $200 \mathrm{~m}$ west-east along the line with data misfit.

Figure A-7. 2-D robust inversion for 2006 line 3 from 0 to $200 \mathrm{~m}$ west-east along the line with data misfit.

Figure A-8. 2-D robust inversion for 2006 line 4 from 0 to $200 \mathrm{~m}$ west-east along the line with data misfit. 

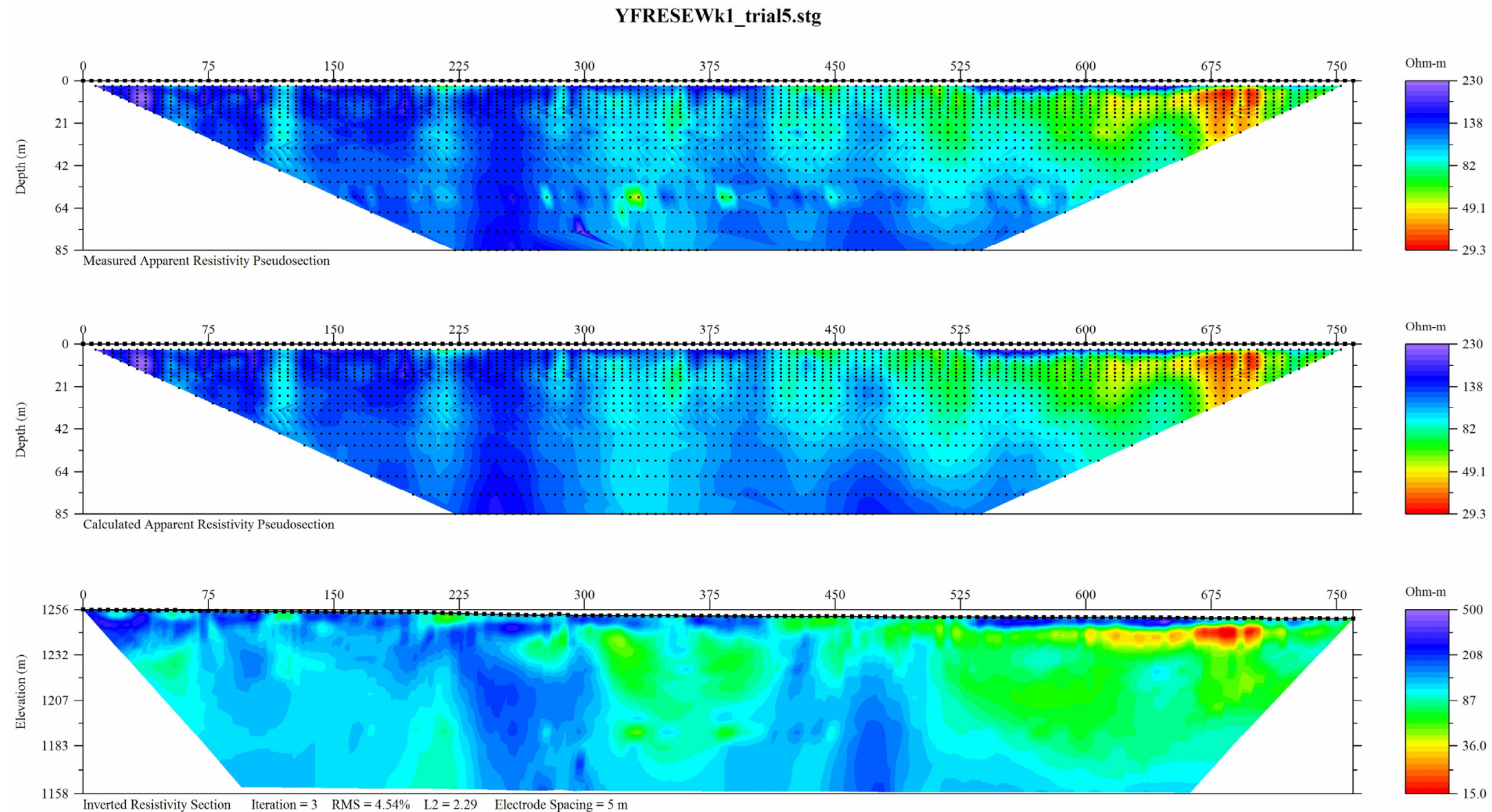

Relative Data Misfit Pseudosection

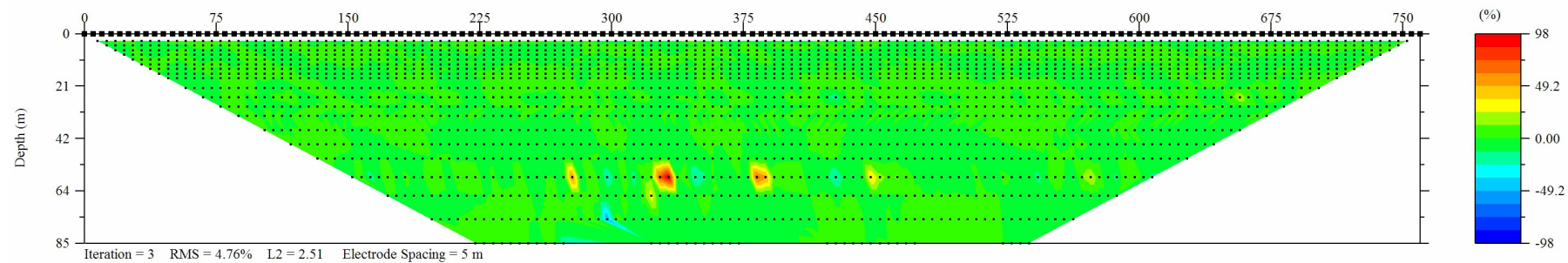

Figure A-1. 2-D robust inversion for 2005 line YFRESEW from 0 to 760 meters west-east along the line with data misfit. 


\section{YFRESEWk2_trial5.stg}
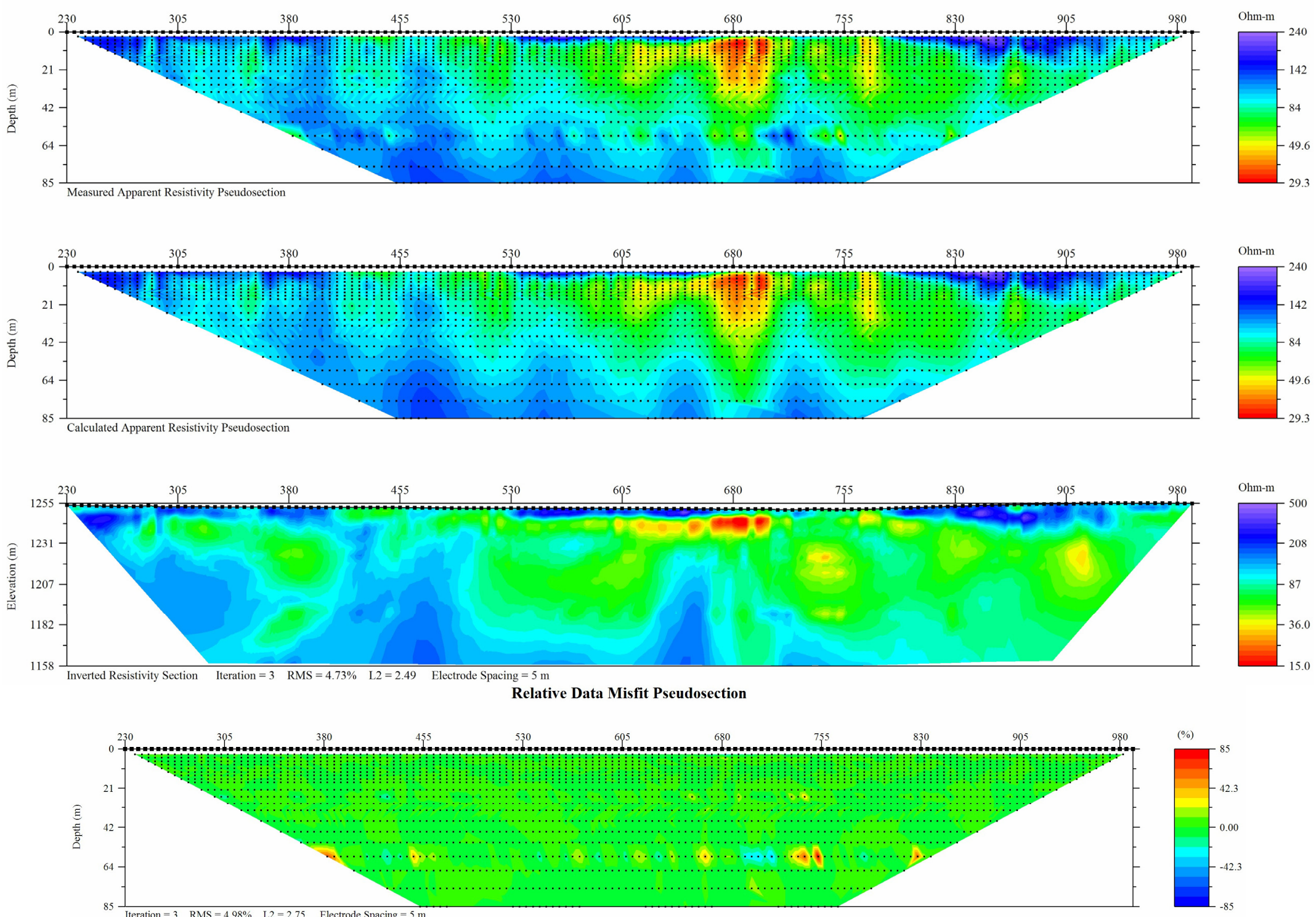

Figure A-2. 2-D robust inversion for 2005 line YFRESEW from 230 to 990 meters west-east along the line with data misfit. 

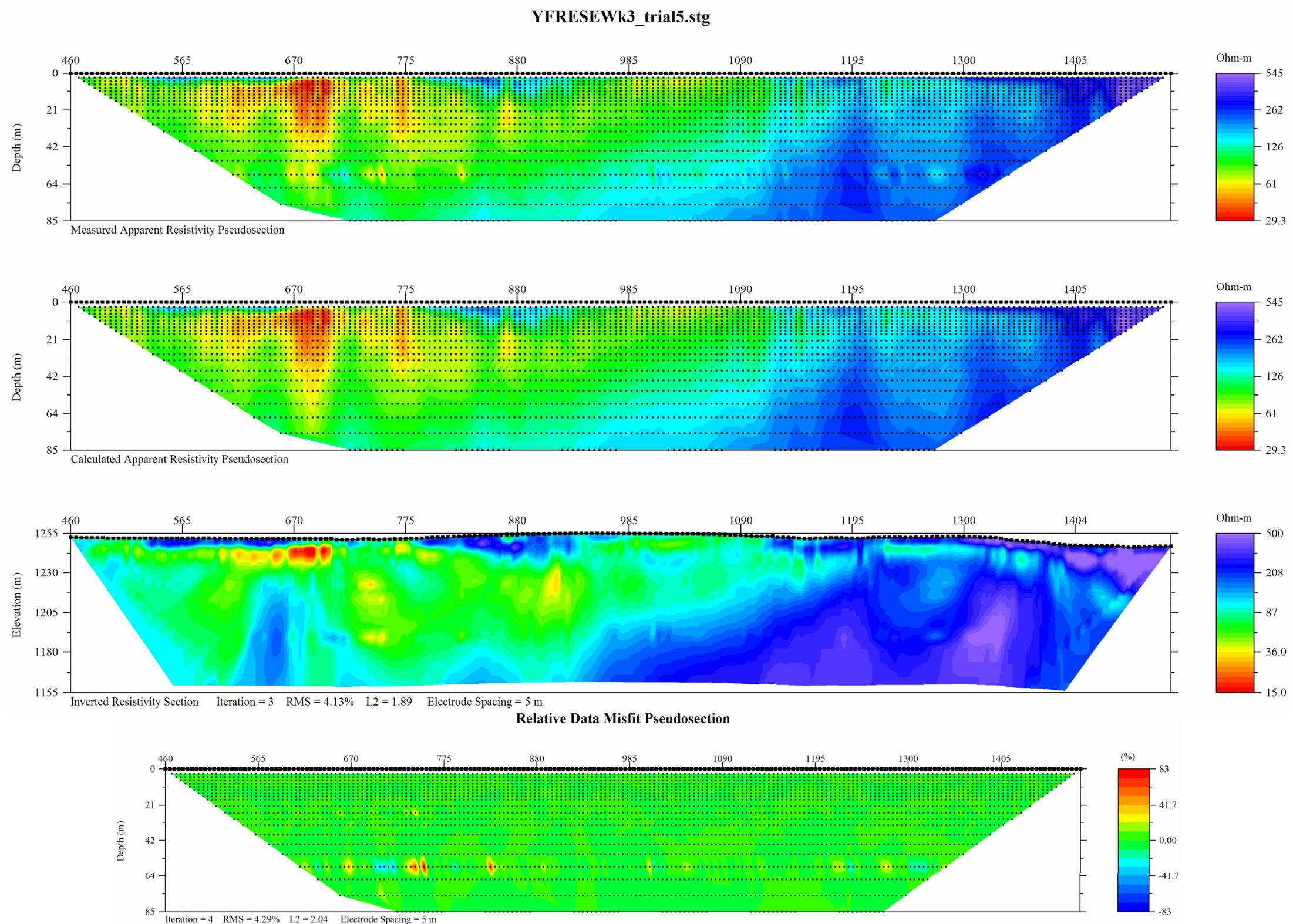

Figure A-3. 2-D robust inversion for 2005 line YFRESEW from 460 to 1,500 meters west-east along the line with data misfit. 

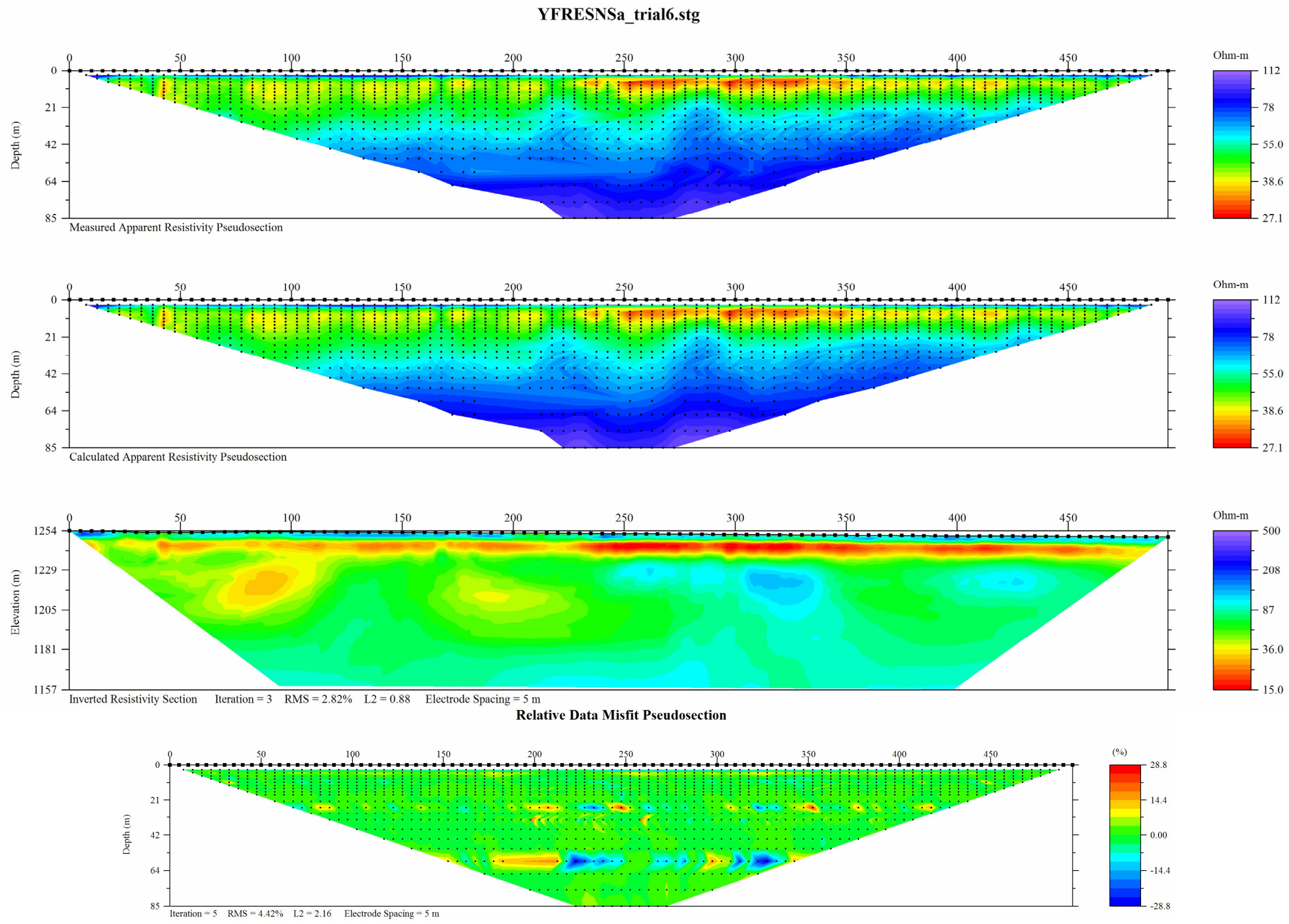

Figure A-4. 2-D robust inversion for 2005 line YFRESNS from 0 to 500 meters north-south along the line with data misfit. 

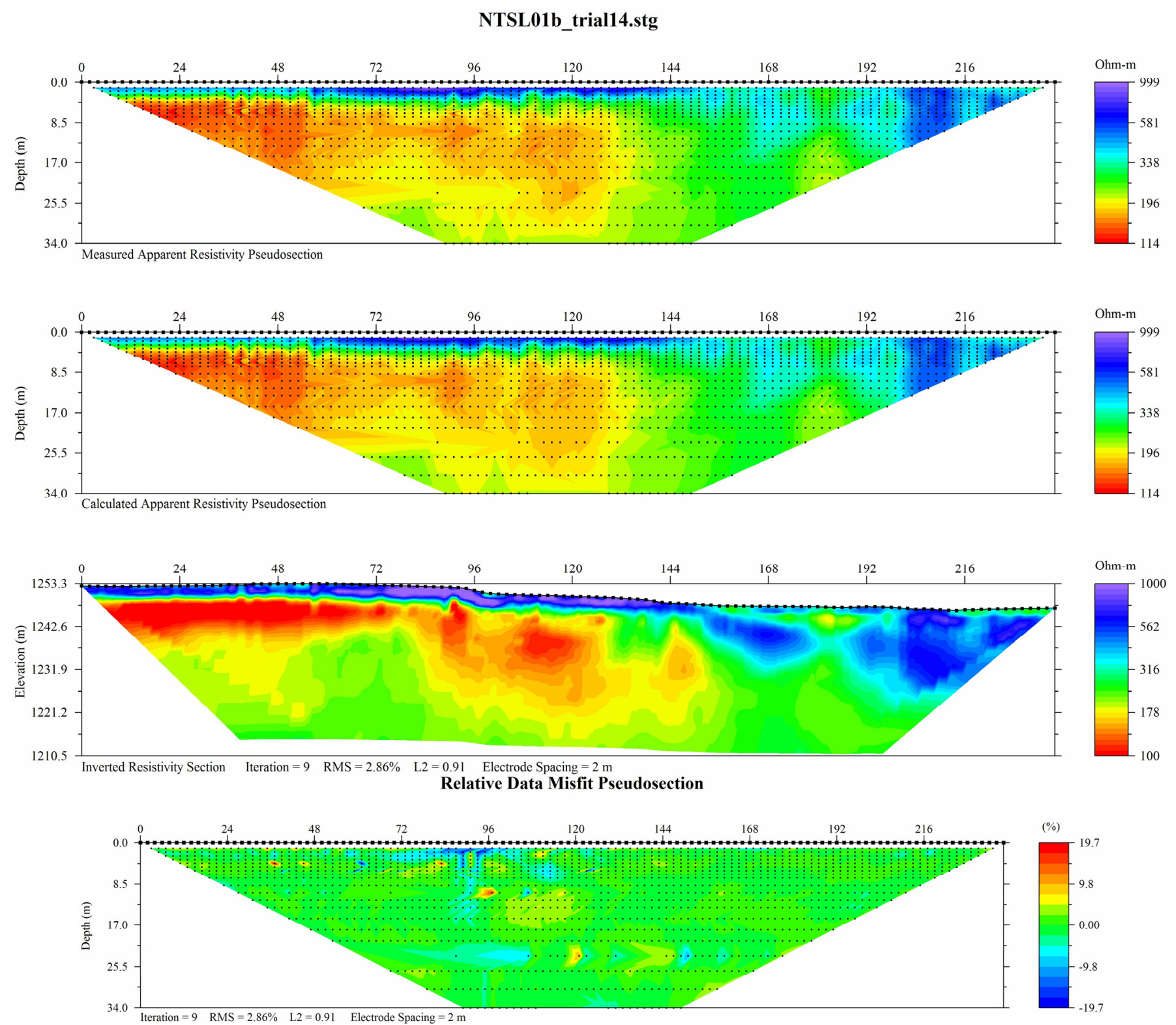

Figure A-5. 2-D robust inversion for 2006 line 1 from 0 to 240 meters west-east along the line with data misfit. 

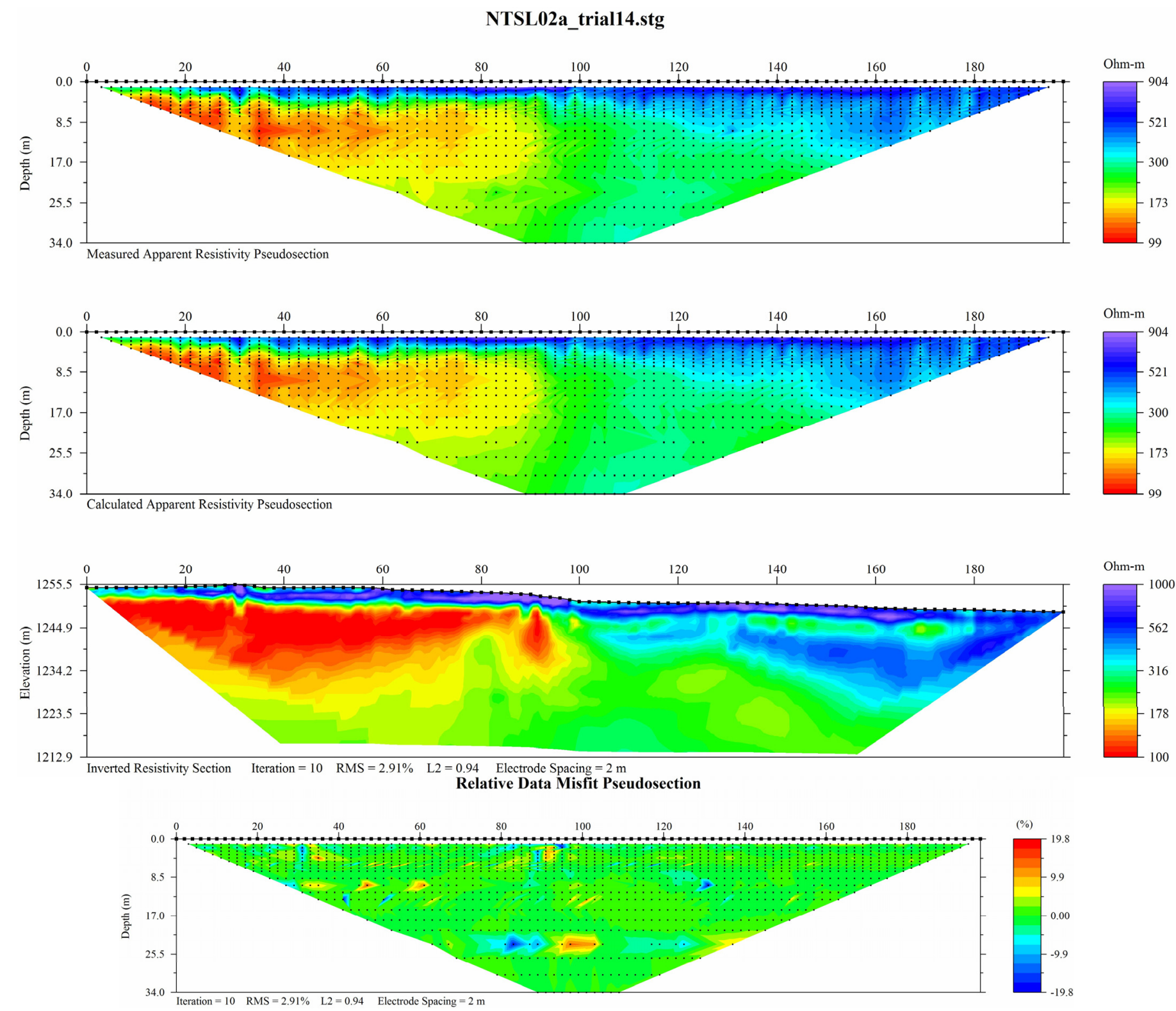

Figure A-6. 2-D robust inversion for 2006 line 2 from 0 to 200 meters west-east along the line with data misfit. 

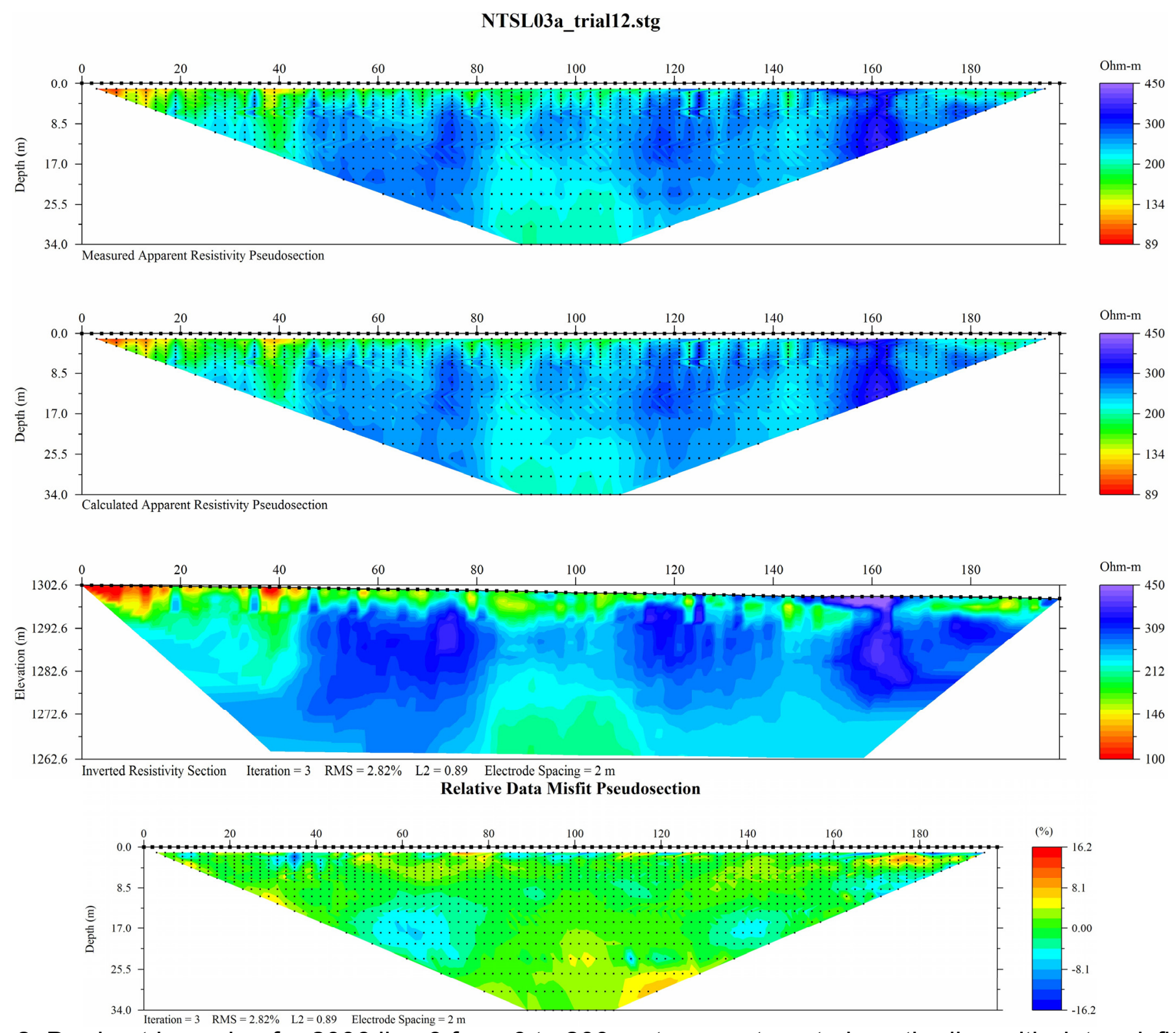

Figure A-7. 2-D robust inversion for 2006 line 3 from 0 to 200 meters west-east along the line with data misfit. 

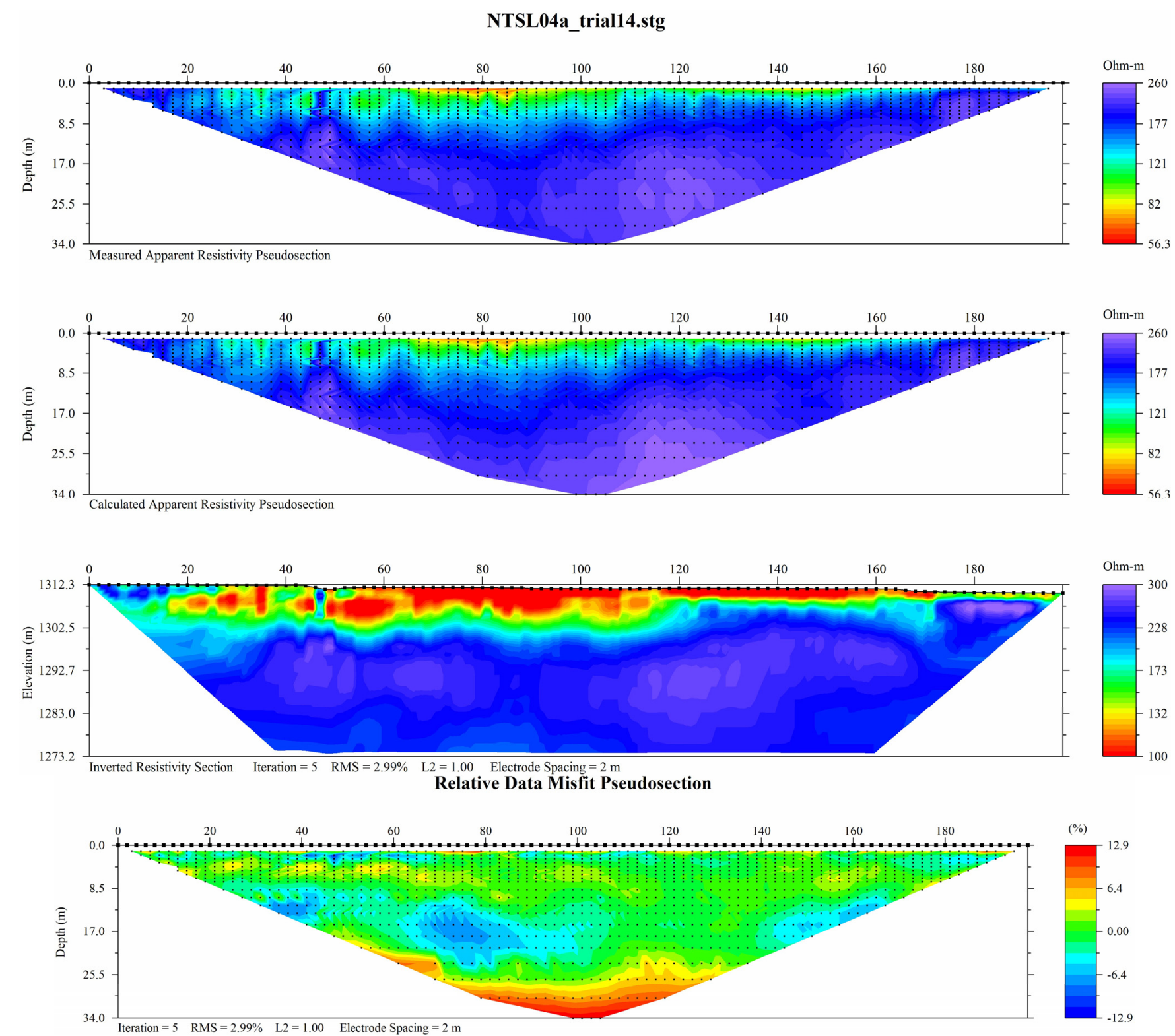

Figure A-8. 2-D robust inversion for 2006 line 4 from 0 to 200 meters west-east along the line with data misfit. 


\section{APPENDIX B - AMT Data}

For each line:

2-D Inversion model with and without model mesh

Apparent Resistivity

Impedance Phase

E-Predicted Coherencies

Impedance Skew

Impedance Polar Plots

Impedance Strike, Rotation, and Tipper Strike

2005 AMT Data:

Line YFRESEW - Figures B-1 through B-28

Line YFRESNS - Figures B-29 through B-40

2006 AMT Data:

Line 1 - Figures B-41 through B-66

Line 2 - Figures B-67 through B-92

Line 3 - Figures B-93 through B-118

Line 4 - Figures B-119 through B-146 


\section{U.S. Geological Survey}

Denver Federal Canter

Denver, Colcrass 30225

MT Data for: YFFC05

Date 082305

\section{急Geotools \\ MT Wristation}

b)

Gesucs Crepraten

5600 Examet or sin 202

Aset, Texa Tans ush

[512) $452-0579$

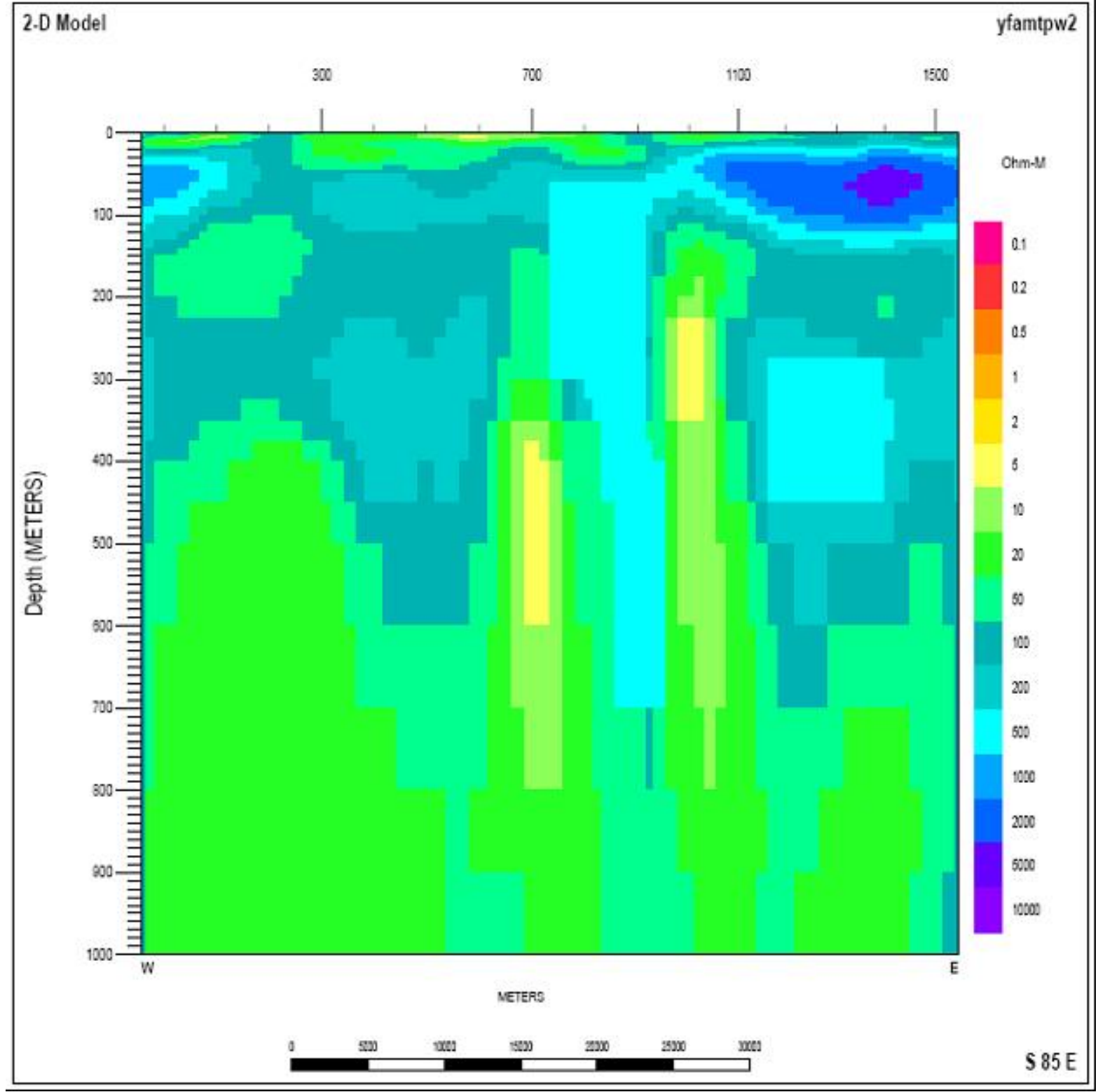

Figure B-1. 7 Z R \pm GP HQMRQDO2-D 2 TM mode inversion model for 2005 east-west line, YFRESEW. Z LWRXXKXHfinite difference mesh. 


\section{U.S. Geological Survey}

Denver Federal Center

Denver, Colorado 80225

MT Data for: YFFC05

Date: 08/2805

\section{FGeotools \\ MT Wokstation}

by

Gesodos Corporton

5803 Ealoones $D$. Sulde 202

Assth, Texx 78731 USh

(512) $454-0579$

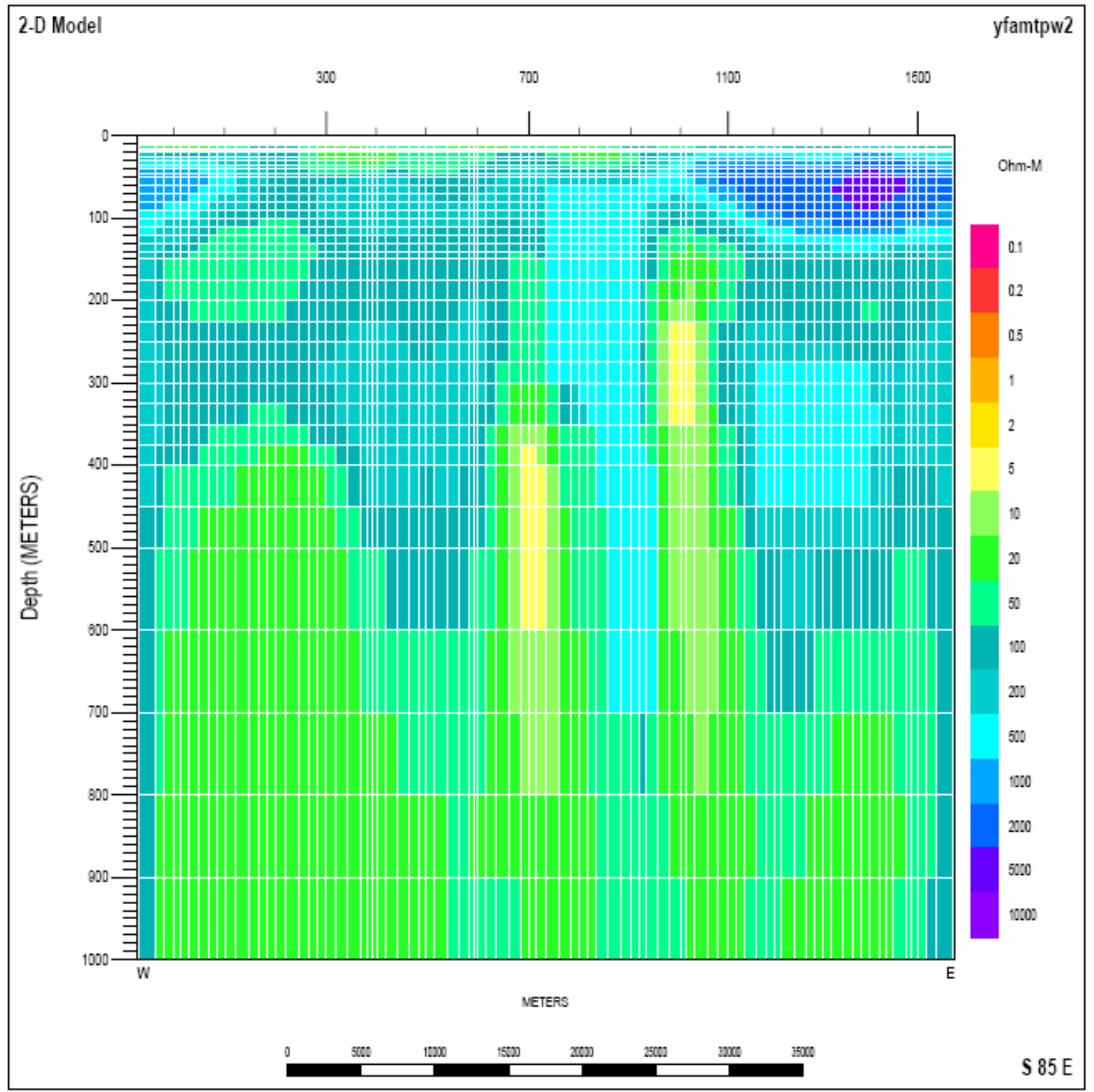

Figure B-2. Two-dimensional (2-D) TM mode forward and inversion model for 2005 east-west line, YFRESEW. with mesh. 


\section{U.S. Geological Survey}

Denver Federal Center

Denver, Colorado 80225

MT Data for: YFFC05

Date: $09 / 17 / 08$

平Geotools

by

Geotools Corporation

5808 Ealcones Dr. Suite 202

Austin, Texas 78731 USA

(512) 454-0679
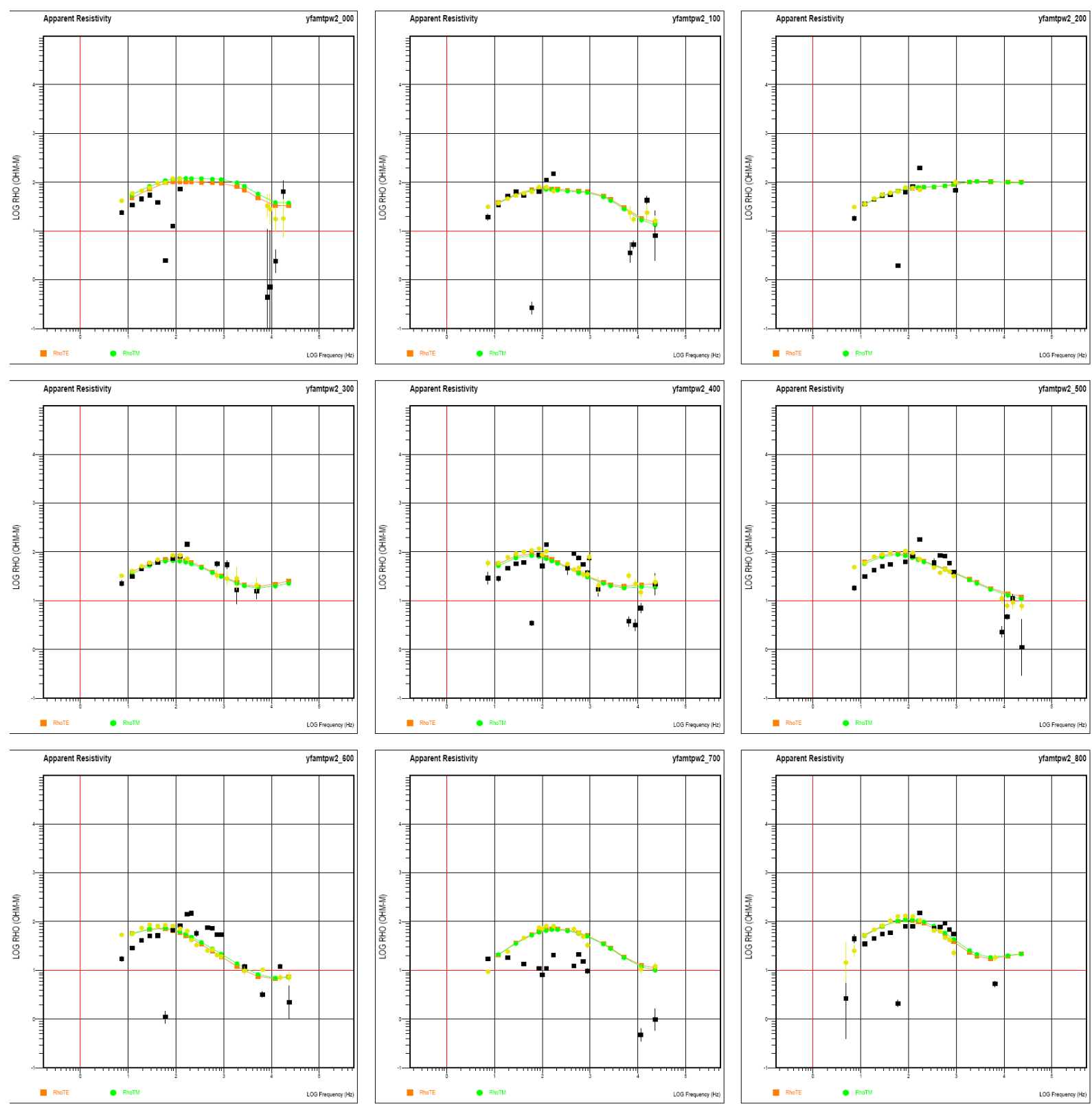

Figure B-3. Apparent resistivity field and TM mode model data for 2005 east-west line, YFRESEW, sites 1 to 9 . 


\section{U.S. Geological Survey}

Denver Federal Center

Denver, Colorado 80225

MT Data for: YFFC05

Date: 09/17/08

拝Geotools

by

Geotools Corporation

5808 Balcones Dr. Suite 202

Austin, Texas 78731 USA

(512) 454-0679
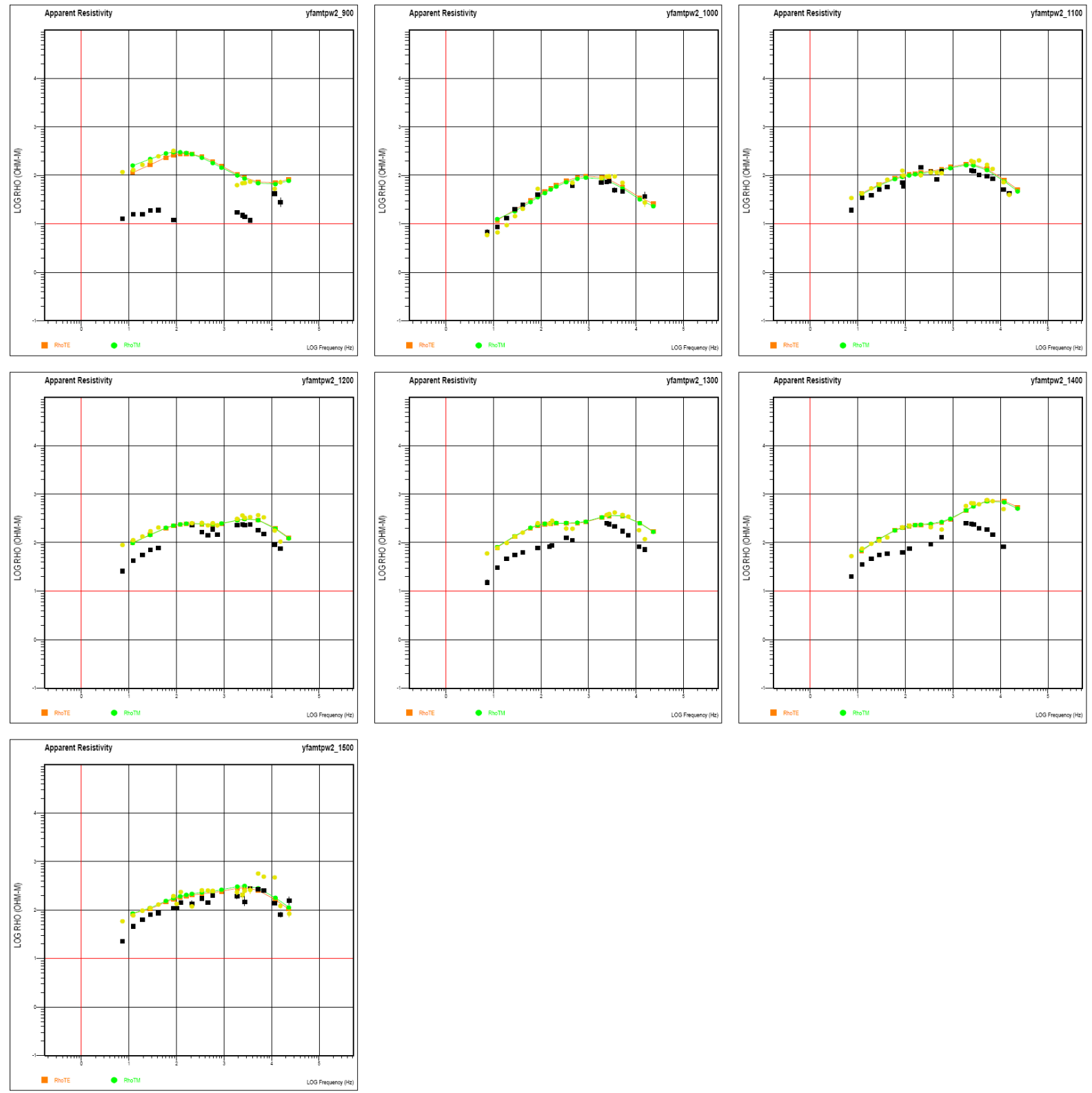

Figure B-4. Apparent resistivity field and TM mode model data for 2005 east-west line, YFRESEW, sites10 to 16. 


\section{U.S. Geological Survey}

Denver Federal Center

Denver, Colorado 80225

MT Data for: YFFC05

Date: $09 / 17 / 08$
拝Geotools

by

Geotools Corporation

5808 Balcones Dr. Suite 202

Austin, Texas 78731 USA

(512) 454-0679
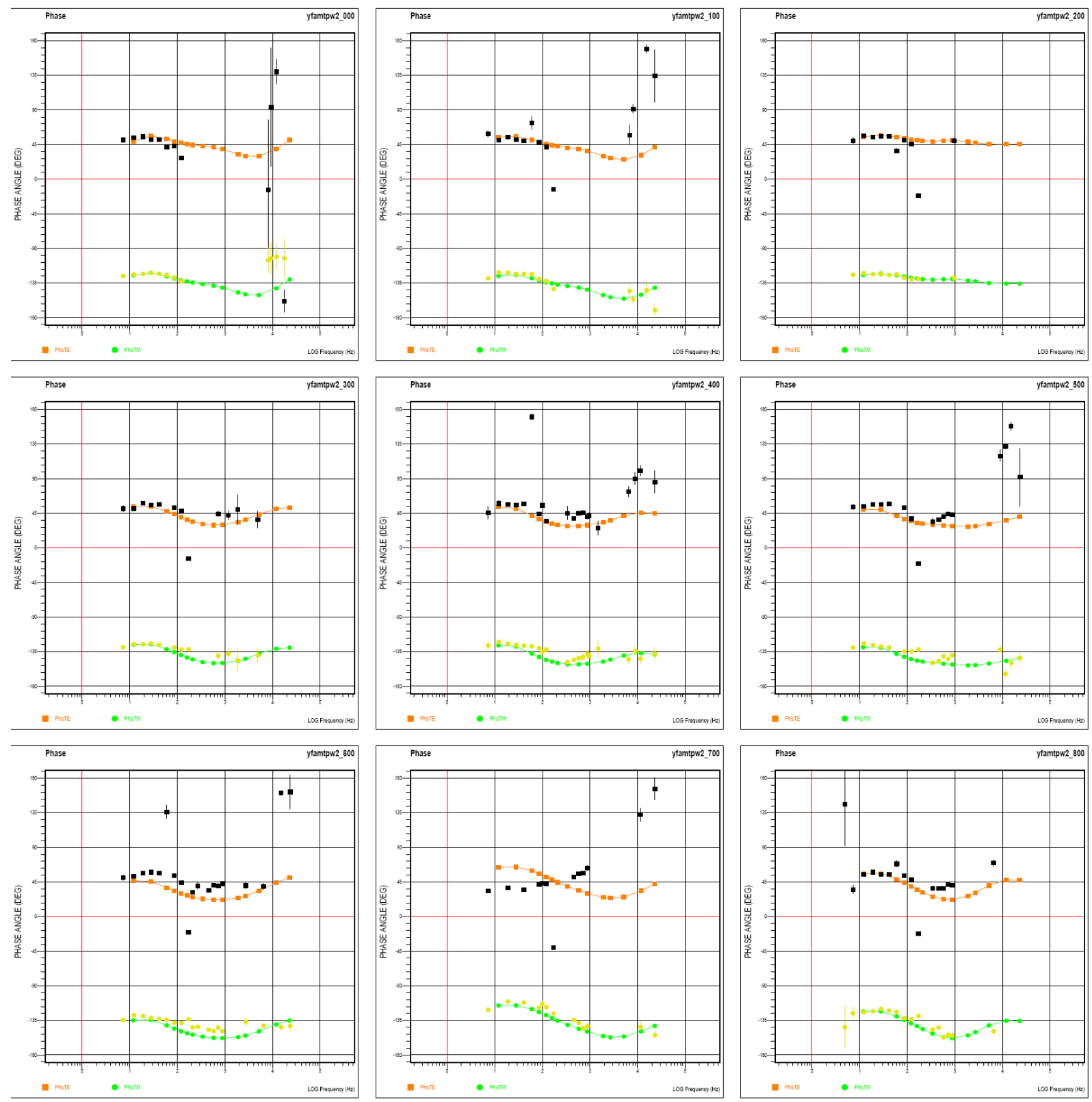

Figure B-5. Impedance phase field and TM mode model data for 2005 east-west line, YFRESEW, sites 1 to 9. 
U.S. Geological Survey

Denver Federal Center

Denver, Colorado 80225

MT Data for: YFFCO5

Date: $09 / 17 / 08$
垂Geotools

MT Workstation

by

Geotools Corporation

5808 Balcones Dr. Suite 202

Austin, Texas 78731 USA

(512) 454-0679
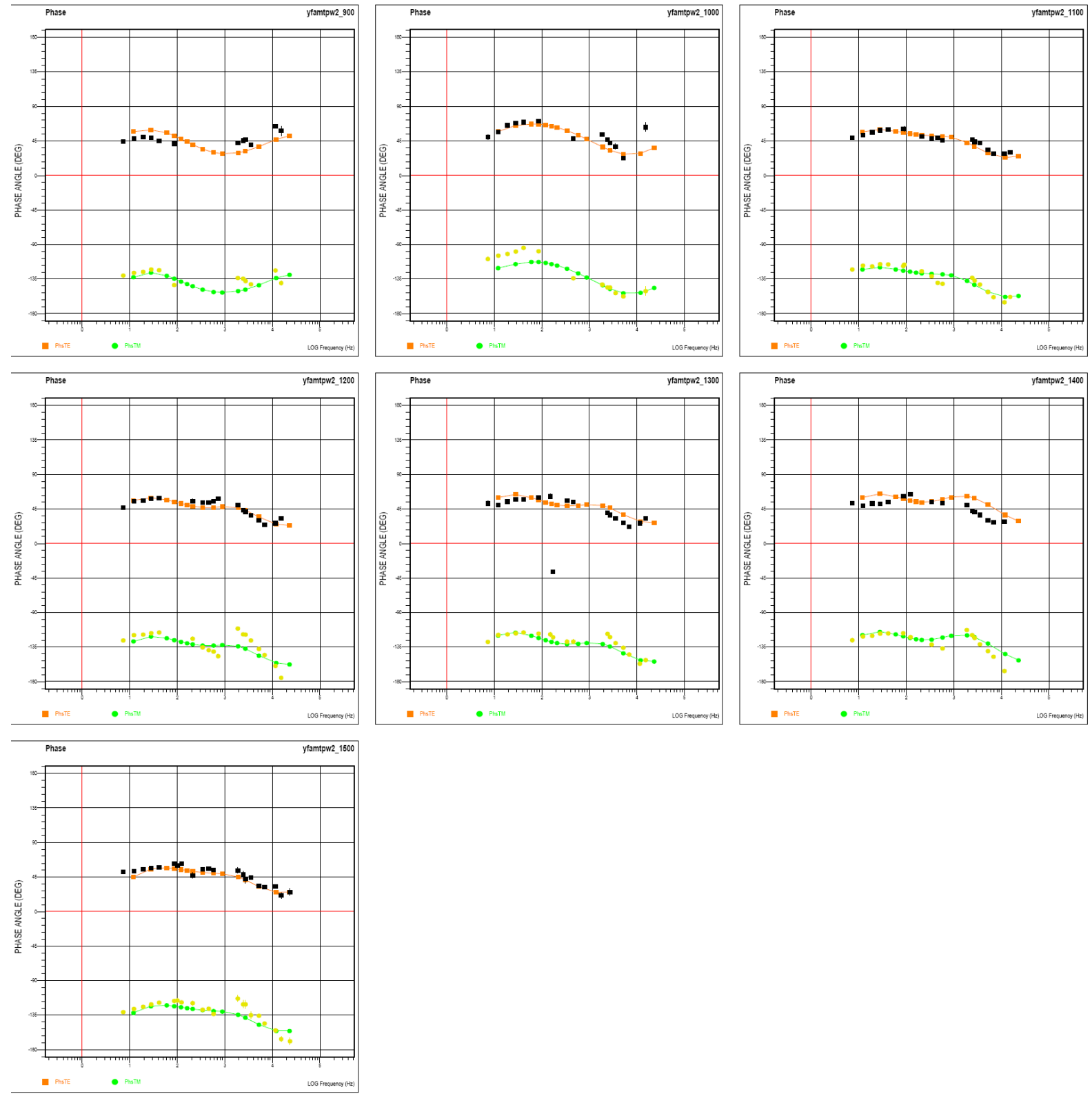

Figure B-6. Impedance phase field and TM mode model data for 2005 east-west line, YFRESEW, sites 10 to 16 . 


\section{U.S. Geological Survey}

Denver Federal Center

Denver, Colorado 80225

MT Data for: YFFC05

Date: 09/25/08

\section{FGeotools}

by

Geotools Corporation

5808 Balcones Dr. Suite 202

Austin, Texas 78731 USA

(512) 454-0679

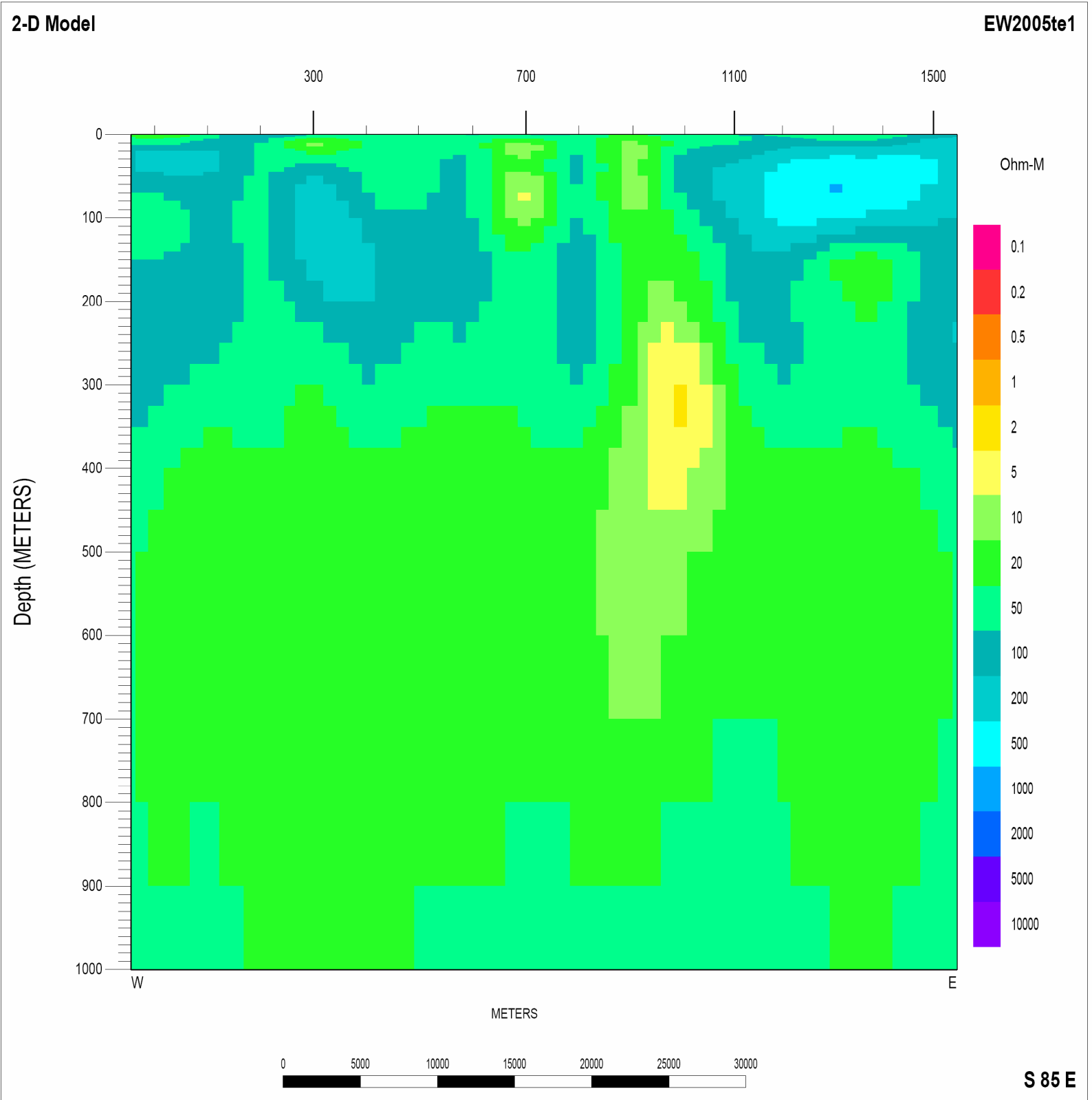

Figure B-7. Two-dimensional TE mode inversion model for 2005 east-west line, YFRESEW. without the finite difference mesh. 


\section{U.S. Geological Survey}

Denver Federal Center

Denver, Colorado 80225

MT Data for: YFFC05

Date: 09/25/08

\section{西Geotools \\ MT Workstation}

by

Geotools Corporation

5808 Balcones Dr. Suite 202

Austin, Texas 78731 USA

(512) 454-0679

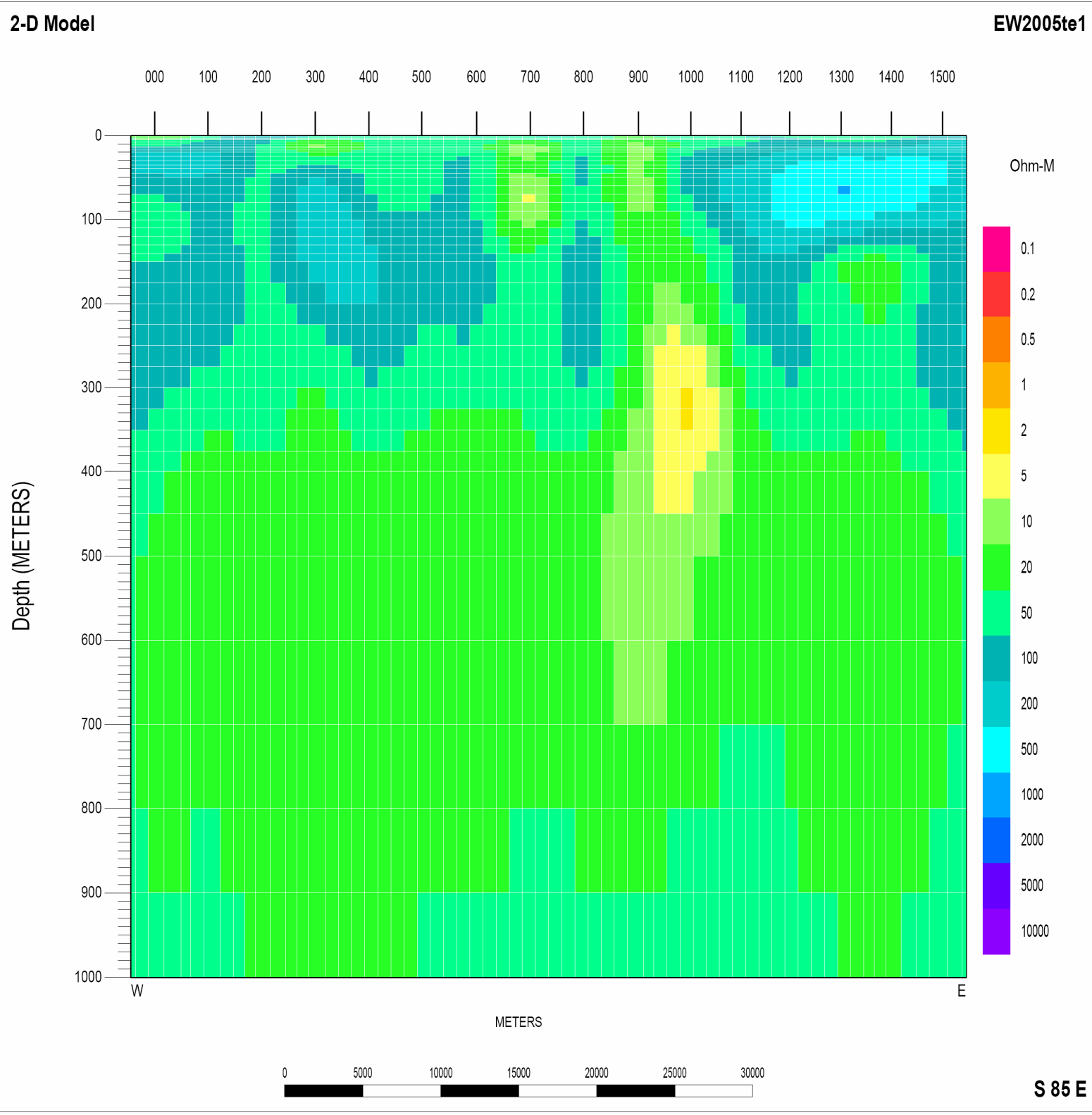

Figure B-8. Two-Gimensional TE mode forward and inversion model for 2005 east-west line, YFRESEW. with mesh. 


\section{U.S. Geological Survey}

Denver Federal Center

Denver, Colorado 80225

MT Data for: YFFC05

Date: $09 / 25 / 08$
垂Geotools

by

Geotools Corporation

5808 Balcones Dr. Suite 202

Austin, Texas 78731 USA

(512) $454-0679$
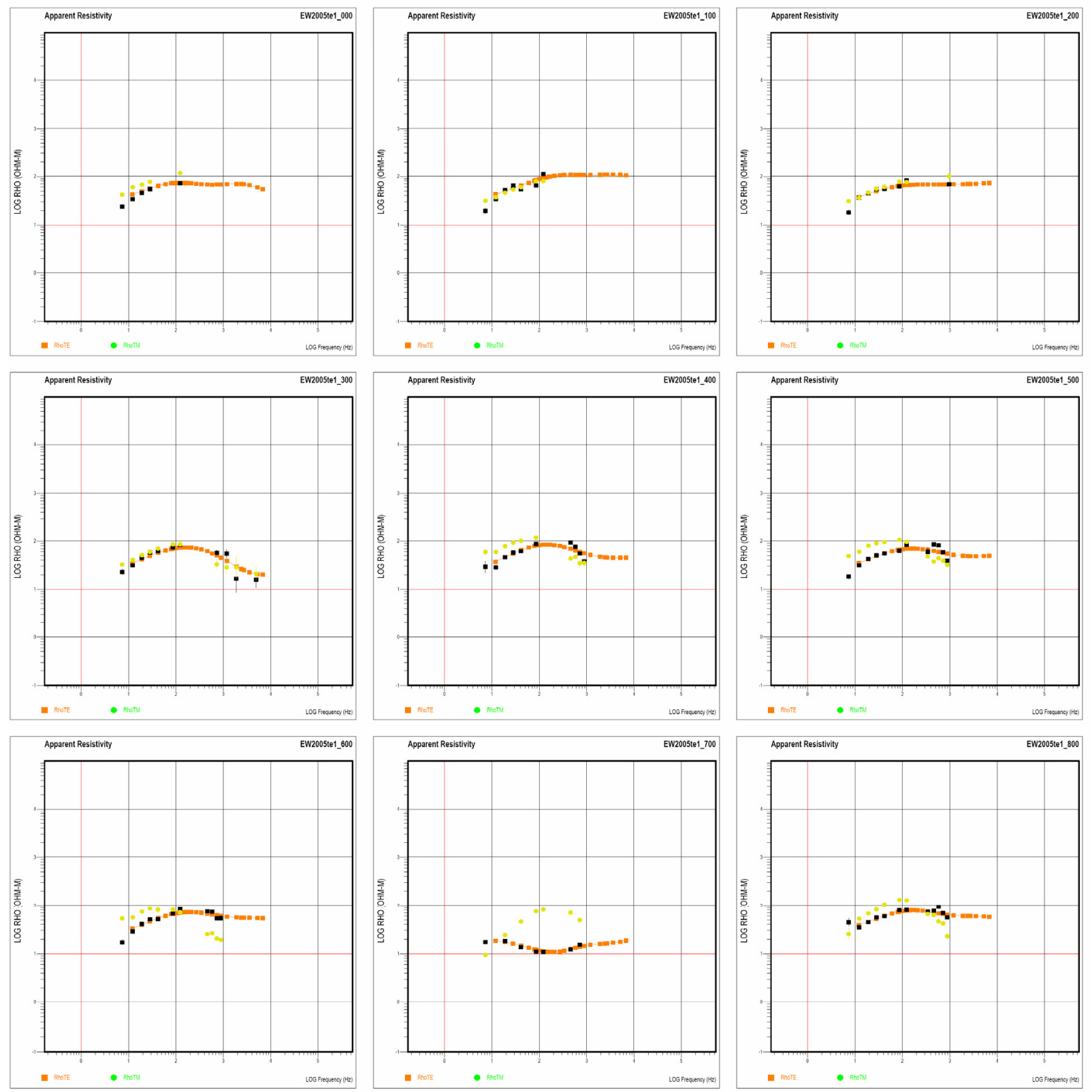

Figure B-9. Apparent resistivity field and TE mode model data for 2005 east-west line, YFRESEW, sites 1 to 9 . 


\section{U.S. Geological Survey}

Denver Federal Center

Denver, Colorado 80225

MT Data for: YFFC05

Date: $09 / 25 / 08$
垂Geotools

by

Geotools Corporation

5808 Balcones Dr. Suite 202

Austin, Texas 78731 USA

(512) $454-0679$
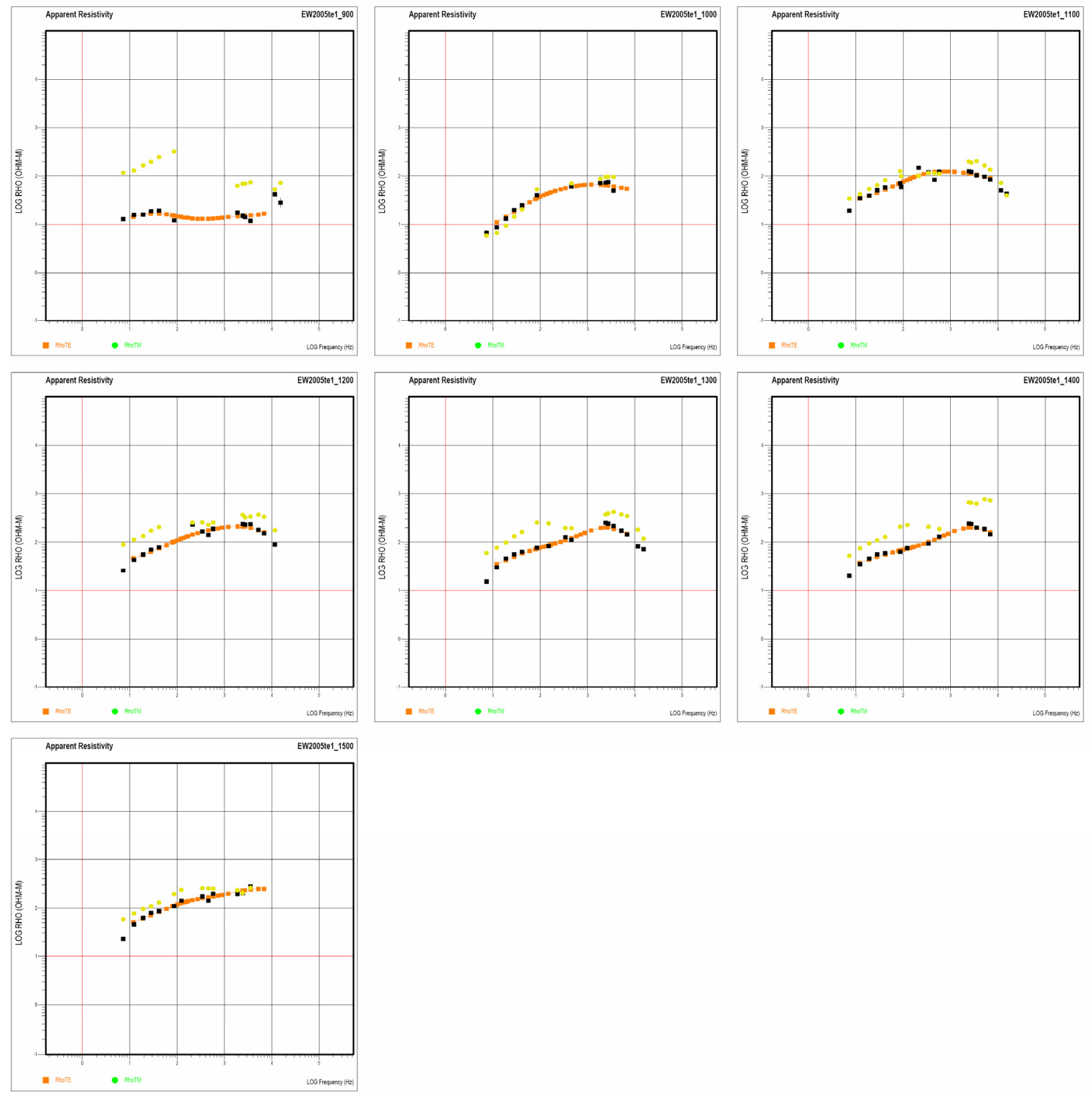

Figure B-10. Apparent resistivity field and TE mode model data for 2005 east-west line, YFRESEW, sites10 to 16. 


\section{U.S. Geological Survey}

Denver Federal Center

Denver, Colorado 80225

MT Data for: YFFC05

Date: $09 / 17 / 08$
平Geotools

by

Geotools Corporation 5808 Balcones Dr. Suite 202 Austin, Texas 78731 USA (512) 454-0679
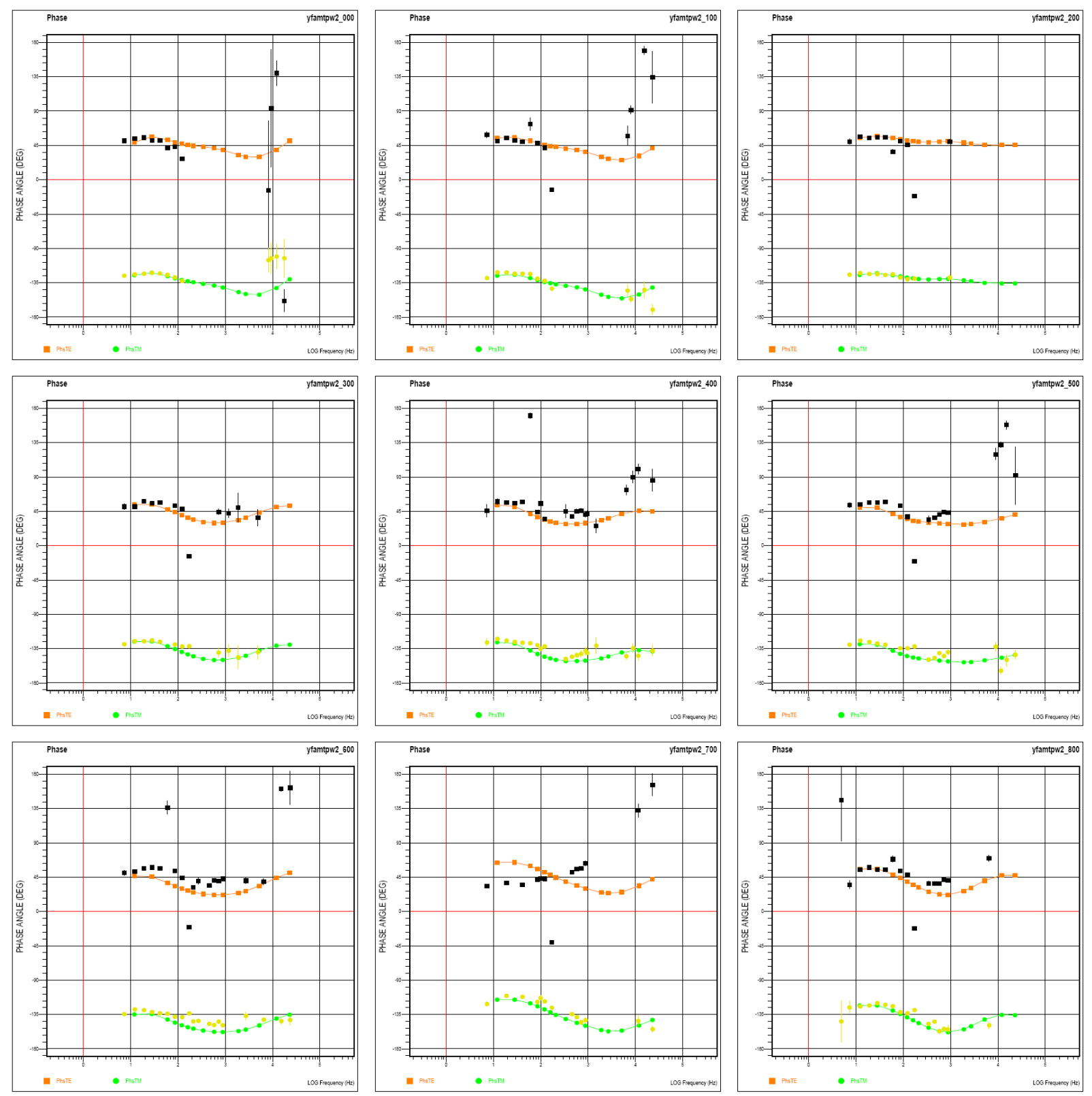

Figure B-11. Impedance phase field and TM mode model data for 2005 east-west line, YFRESEW, sites 1 to 9 . 


\section{U.S. Geological Survey}

Denver Federal Center

Denver, Colorado 80225

MT Data for: YFFC05

Date: 09/17/08

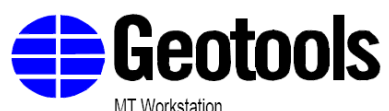

MT Workstation

by

Geotools Corporation

5808 Balcones Dr. Suite 202

Austin, Texas 78731 USA

(512) 454-0679
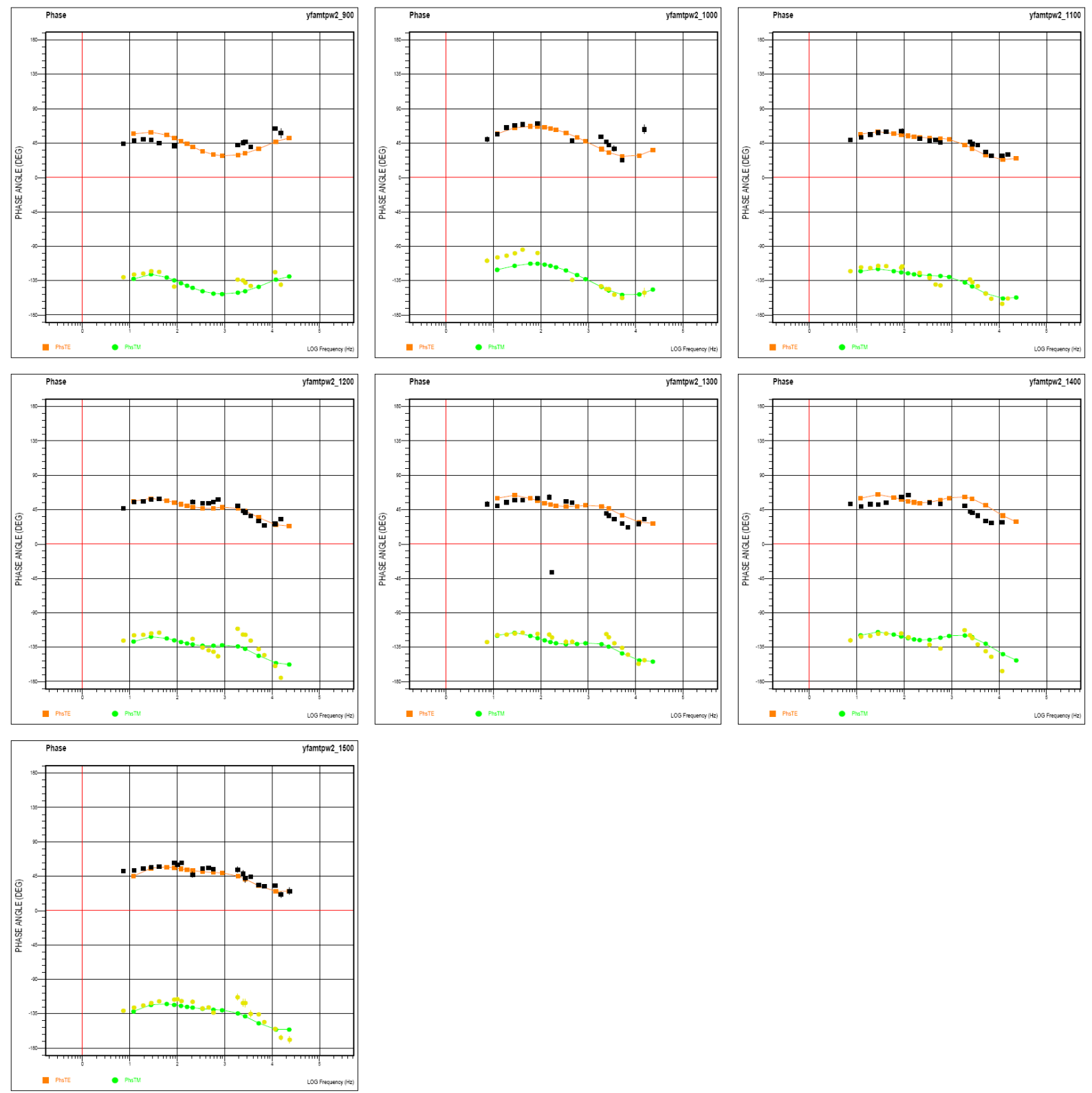

Figure B-12. Impedance phase field and TE mode model data for 2005 east-west line, YFRESEW, sites 10 to 16 . 


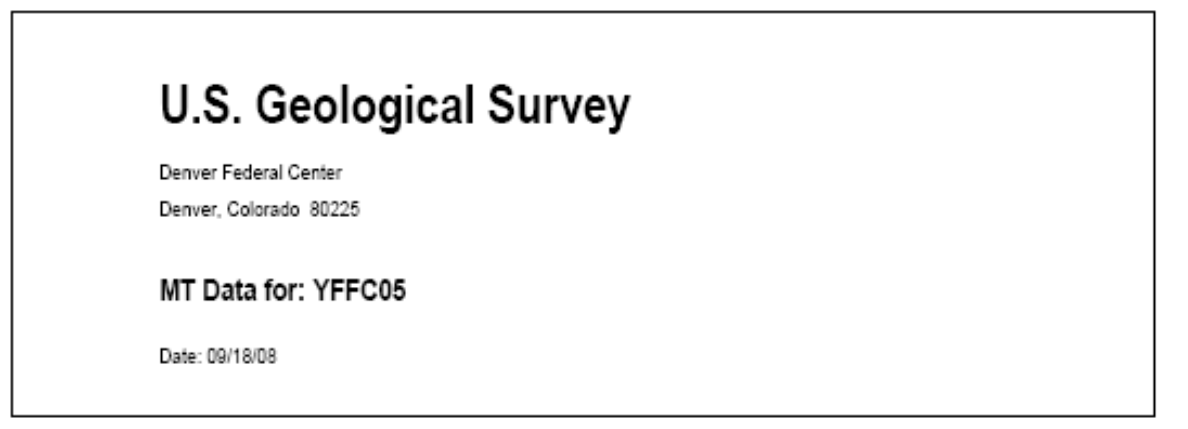

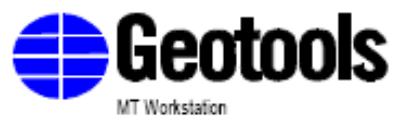

by

Geotools Coppration

5028 Balocones Dr. Sulite 202

Ausin, Texas 78731 USA

(512) 4540678
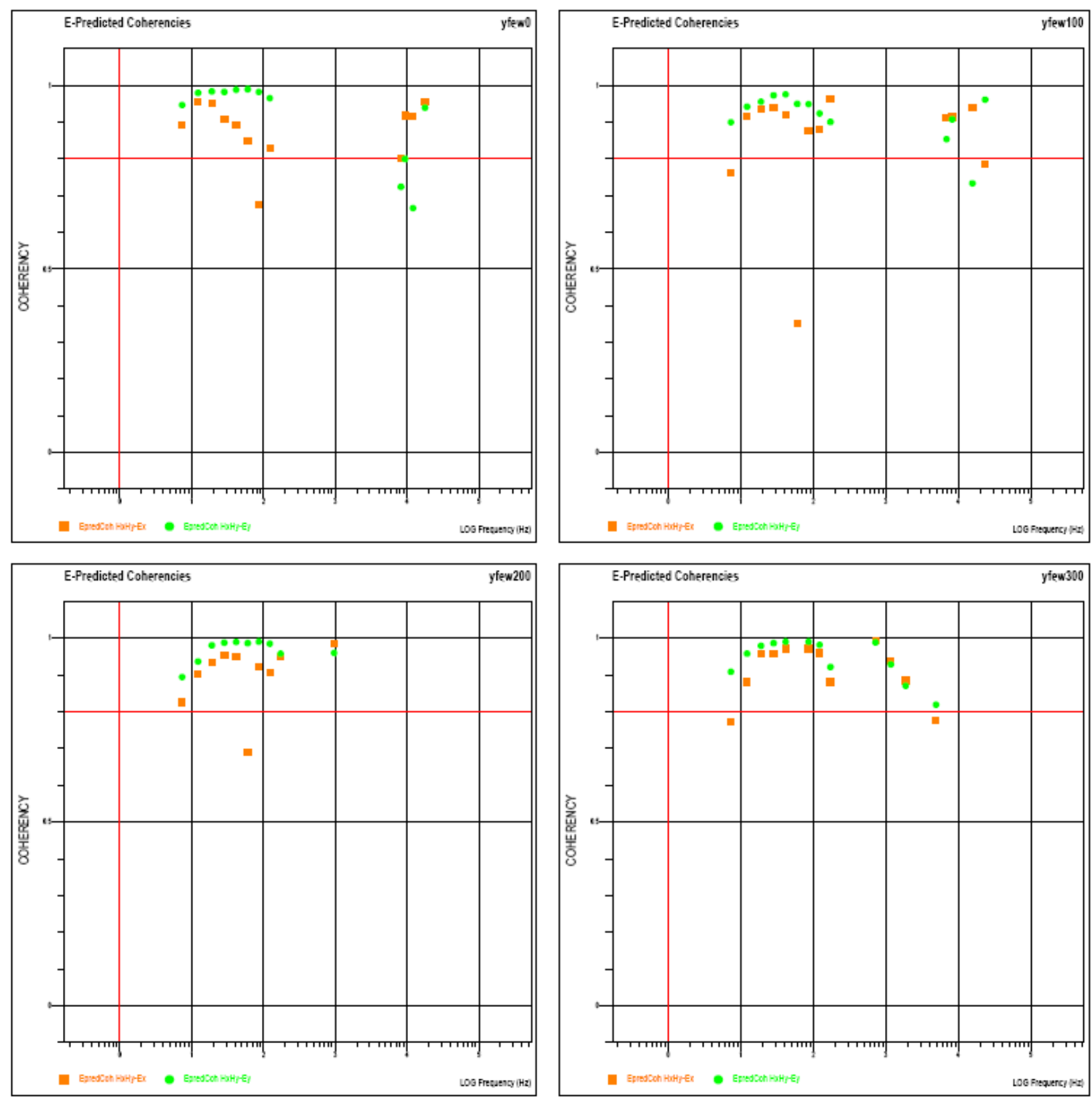

Figure B-13. Coherency data for 2005 east-west line, YFRESEW, sites 1 to 4. 


\section{U.S. Geological Survey}

Denver Federal Center

Denver, Colorado 80225

MT Data for: YFFC05

Date: 08/18/08
FGeotools

by

Geobols Corpration

5008 Balocones Dr. Silite 202

Ausin. Texas 78731 USA

(512) 45406078
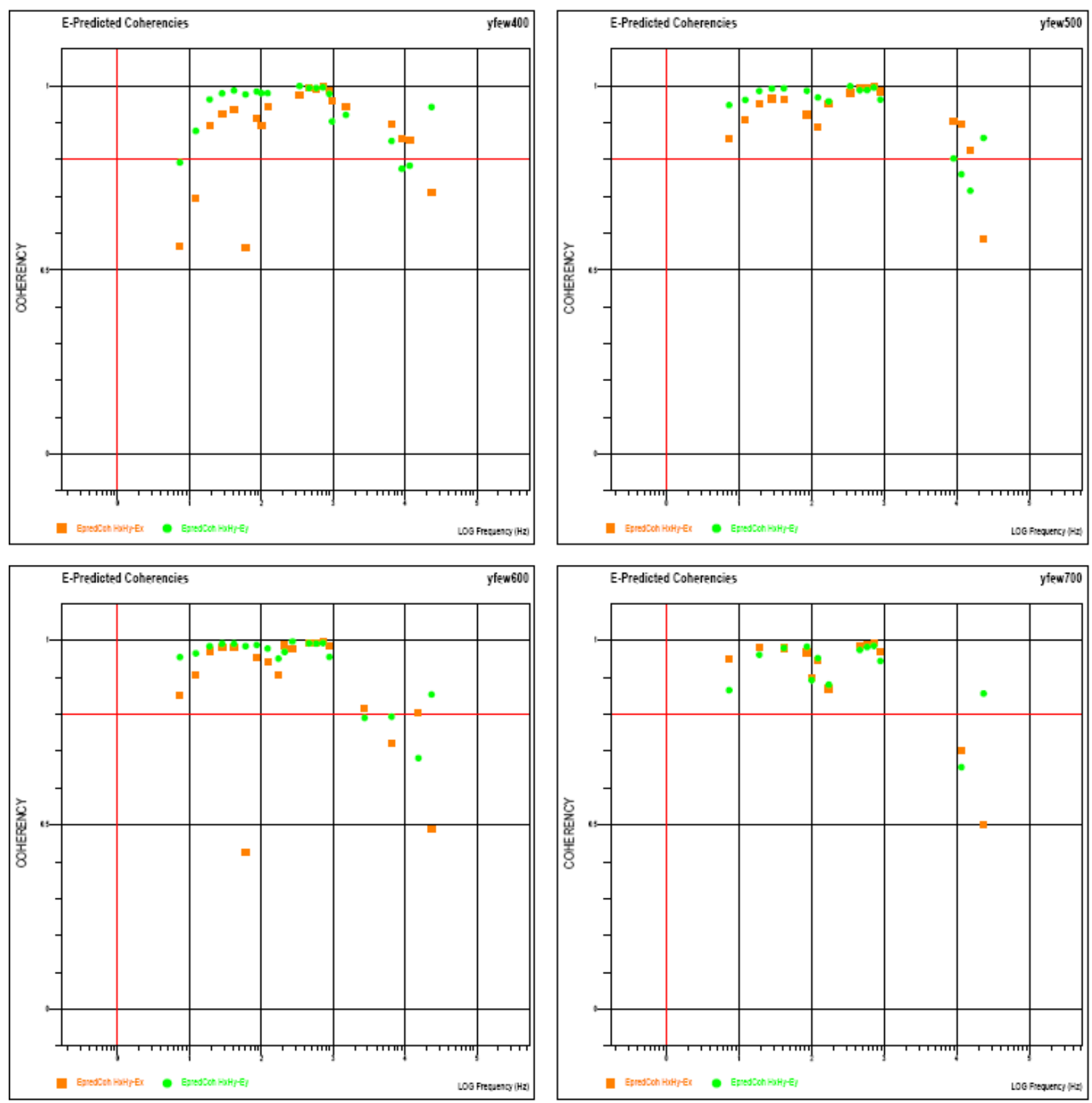

Figure B-14. Coherency data for 2005 east-west line, YFRESEW, sites 5 to 8. 


\section{U.S. Geological Survey}

Denver Federal Center

Denver, Colorado 80225

MT Data for: YFFC05

Date: 09/18/08

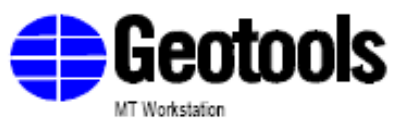

by

Geotools Corporation

6008 Babones Dr. Suile 202

Ausin. Texas 78731 USA

(512) 4540678
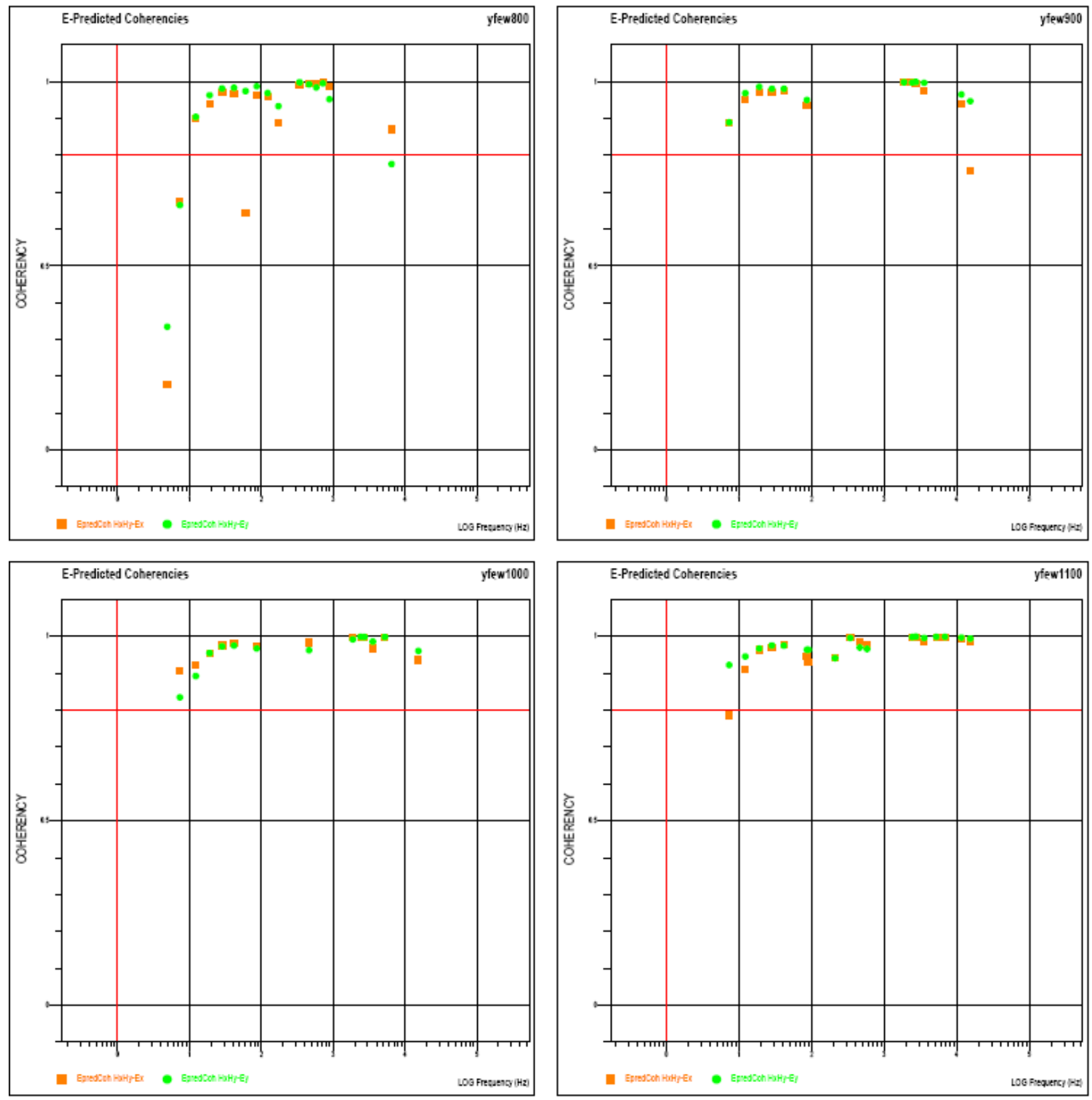

Figure B-15. Coherency data for 2005 east-west line, YFRESEW, sites 9 to 12. 


\section{U.S. Geological Survey}

Denver Federal Center

Denver, Colorado 80225

MT Data for: YFFC05

Date: 09/18/08
车Geotools

by

Geotools Corporation

5808 Balcones Dr. Sulte 202

Austin, Texas 78731 USA

(512) 454-0679
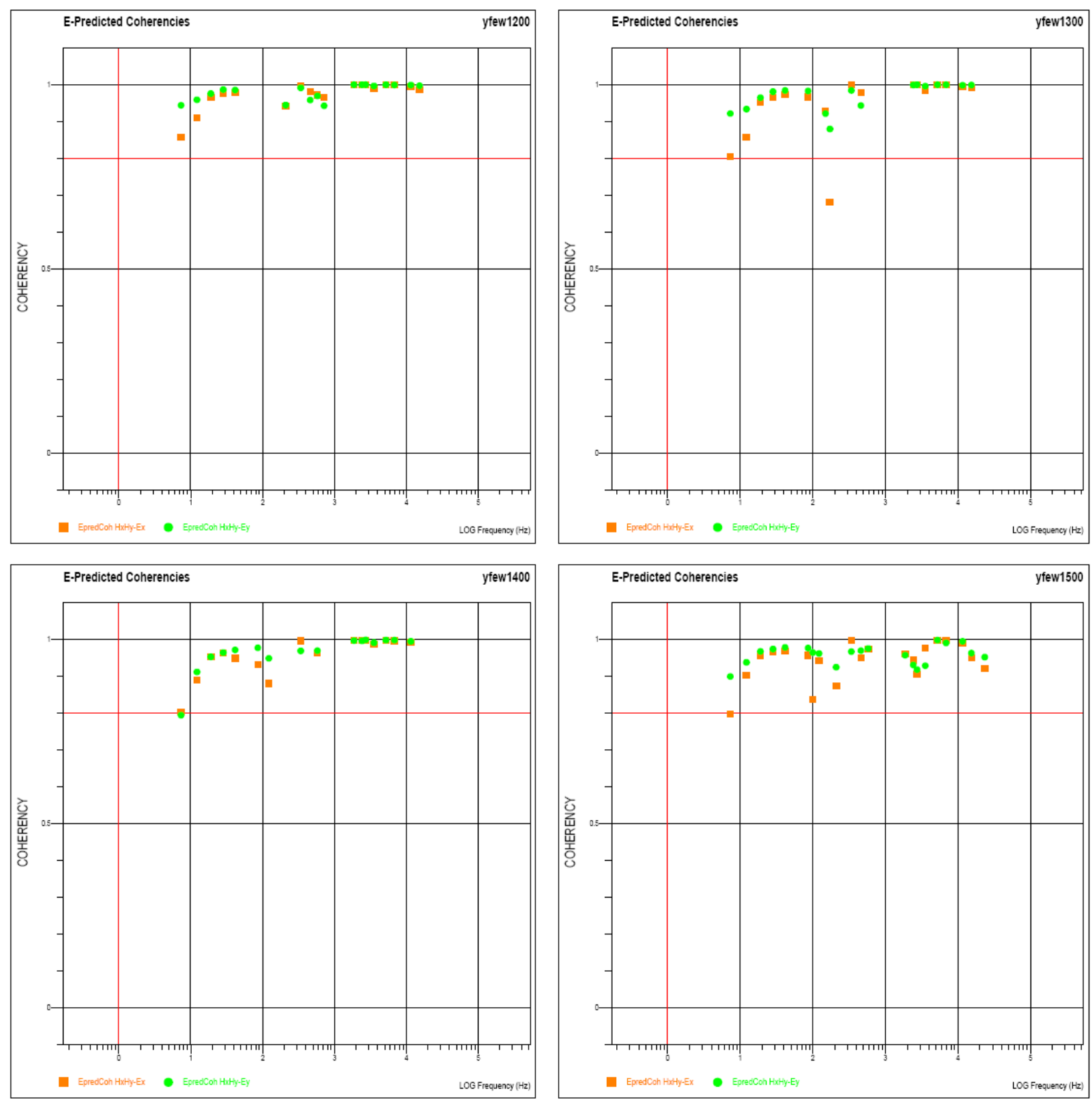

Figure B-16. Coherency data for 2005 east-west line, YFRESEW, sites 13 to 16. 


\section{U.S. Geological Survey}

Denver Federal Center

Denver, Colorado 80225

MT Data for: YFFC05

Date: 09/18/08

F Geotools

by

Geobocis Coppration

5008 Balocones Or. S.ilie 200

Ausin, Texas 78731 USA

(512) 4540678
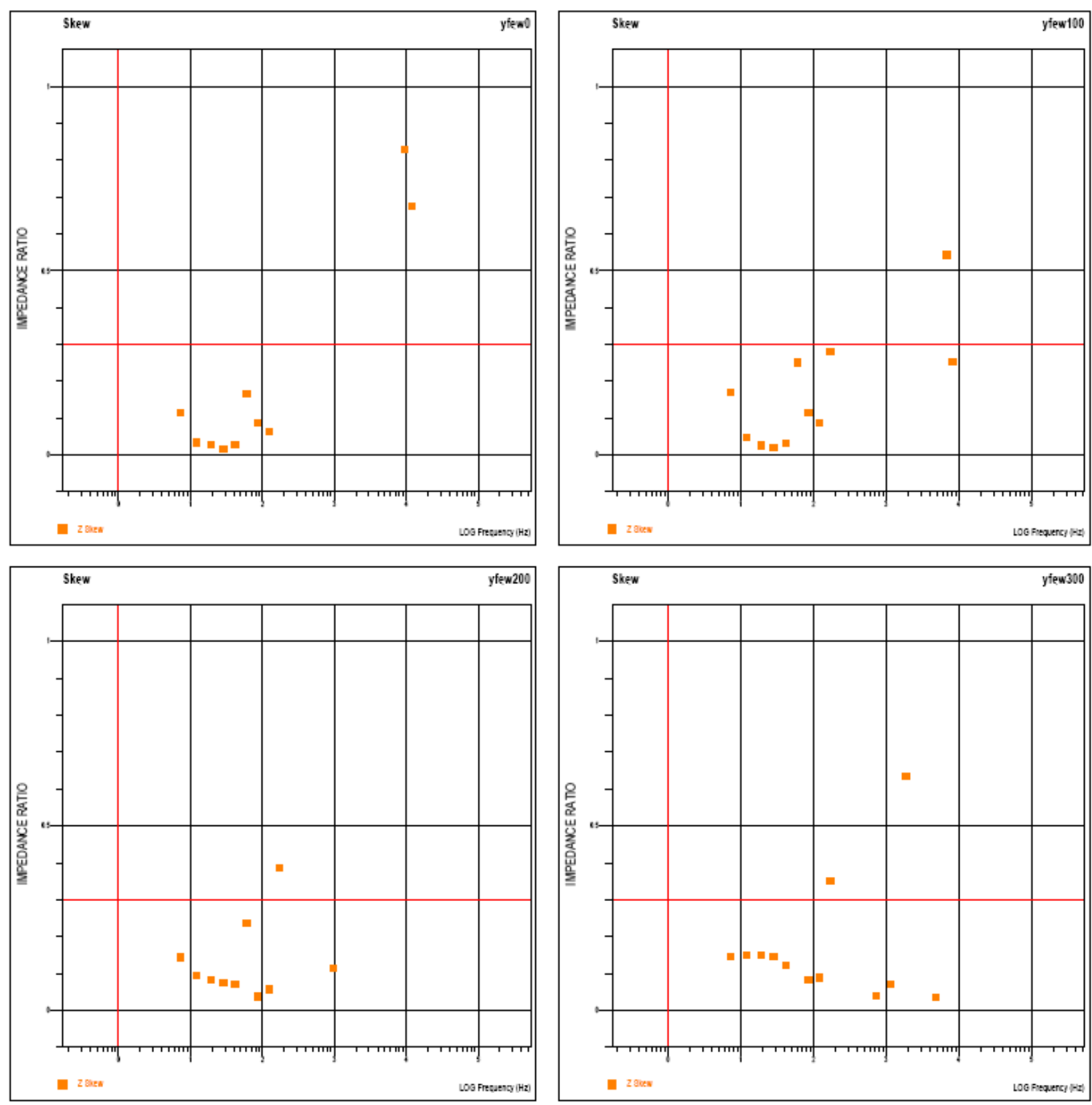

Figure B-17. Impedance skew data for 2005 east-west line, YFRESEW, sites 1 to 4. 


\section{U.S. Geological Survey}

Denver Federal Center:

Denver, Colorado 80225

MT Data for: YFFC05

Date: 09/18/08
业Geotools

MT Workstafon

by

Geotocls Corporation

5608 Balocones Dr. Saile 202

Ausin. Texas 78731 USA

(512) 45440678
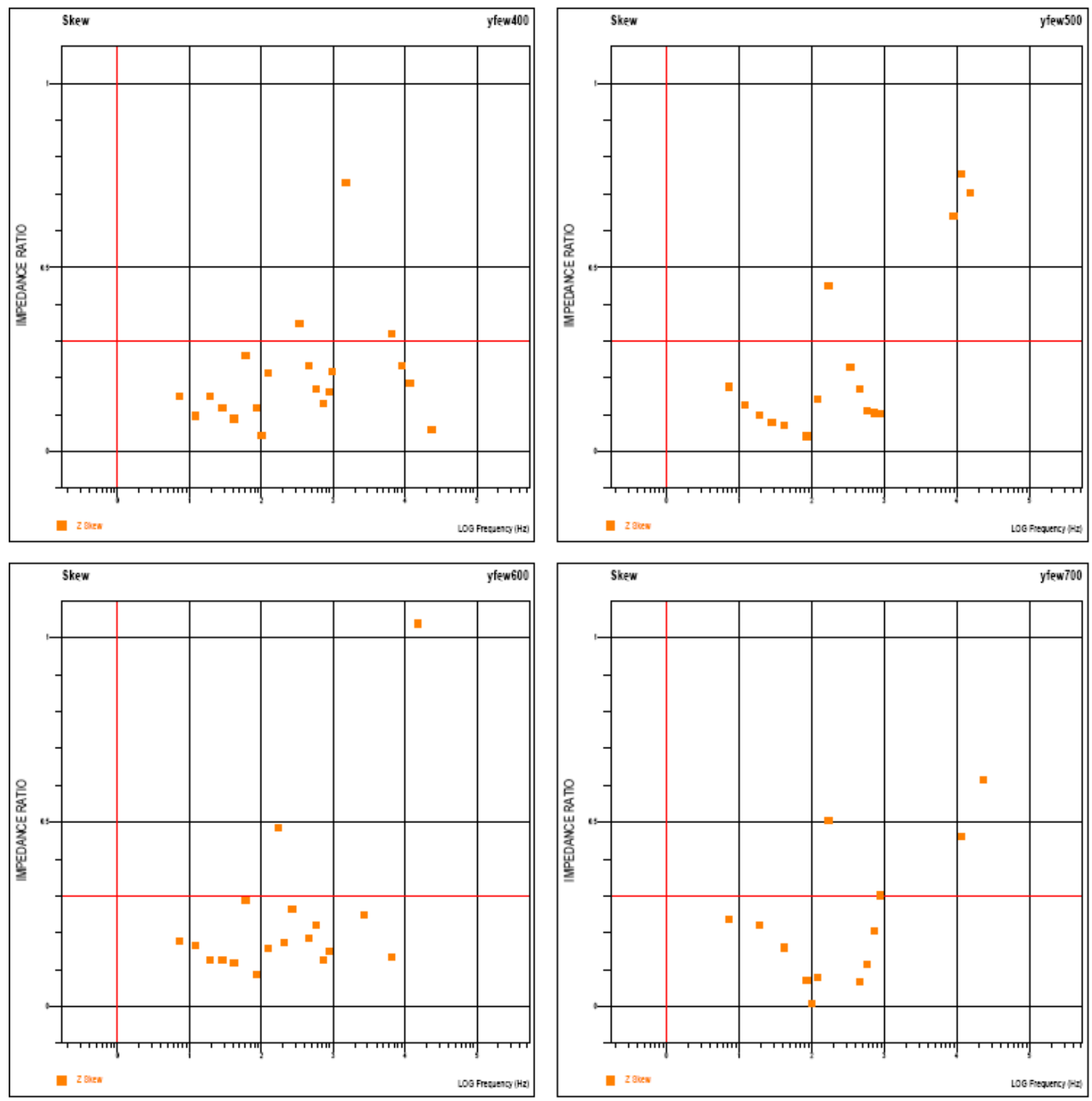

Figure B-18. Impedance skew data for 2005 east-west line, YFRESEW, sites 5 to 8. 

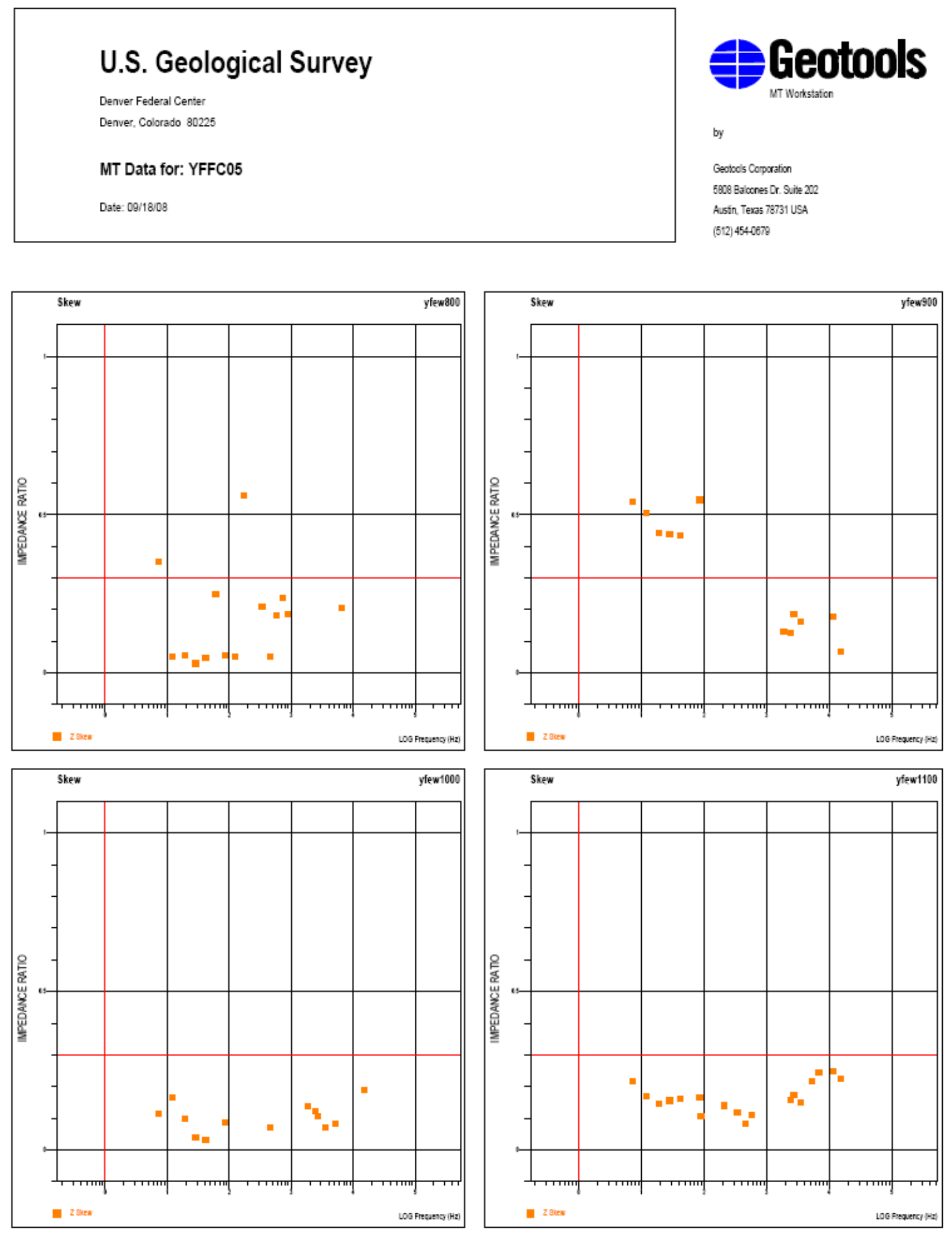

Figure B-19. Impedance skew data for 2005 east-west line, YFRESEW, sites 9 to 12. 


\section{U.S. Geological Survey}

Denver Federal Center

Denver, Colorado 80225

MT Data for: YFFC05

Date: 09/18/08
FGeotools

by

Geotocls Corporation

5028 Babones Or. Sulit: 202

Ausin, Texas 78731 USA

(512) 4540678
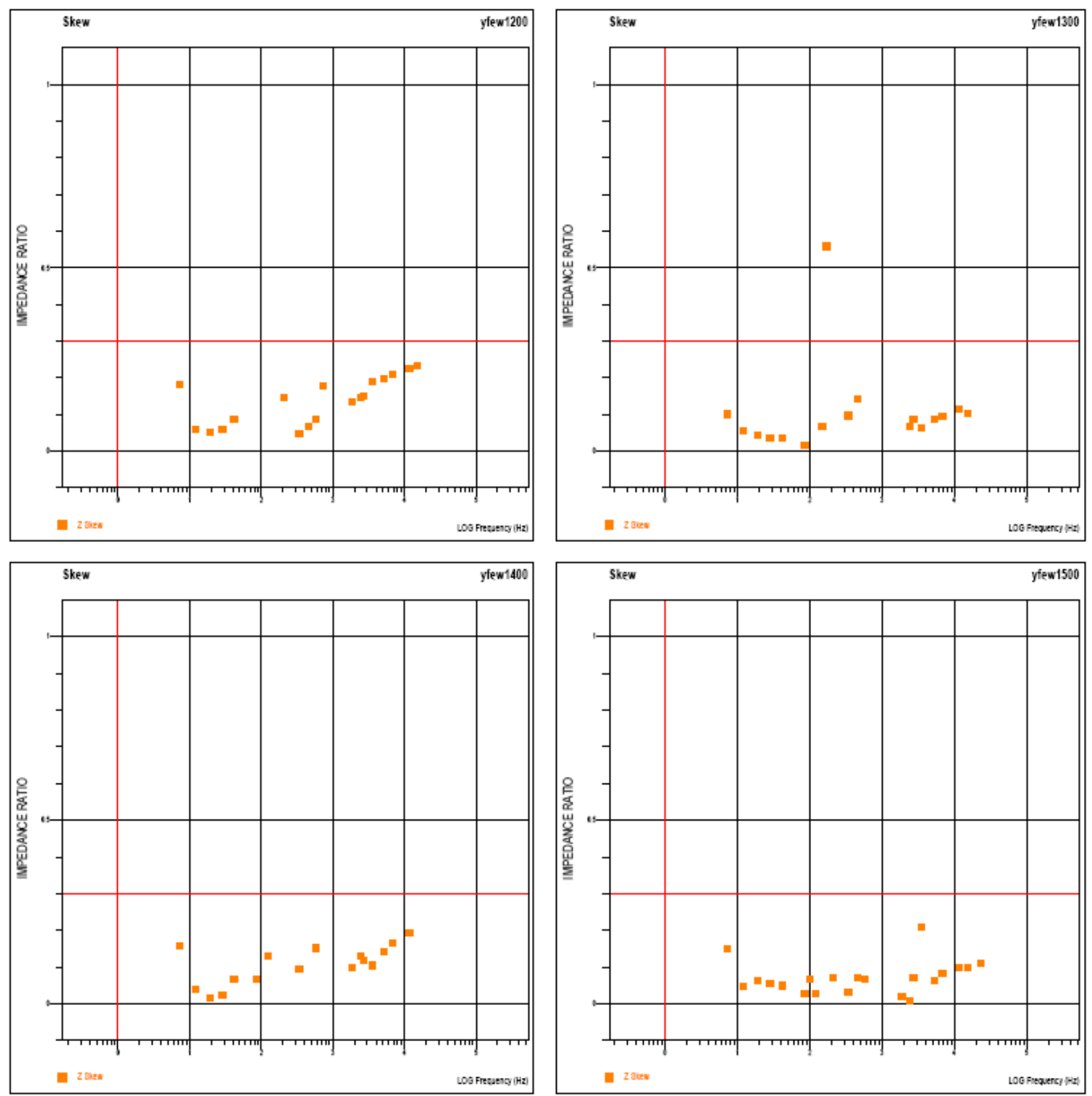

Figure B-20. Impedance skew data for 2005 east-west line, YFRESEW, sites 13 to 16. 


\section{U.S. Geological Survey}

\section{Denver Federal Center}

Denver, Colorado 80225

MT Data for: YFFC05

Date: 09/18/08
奉Geotools

by

Geotools Corporation

5808 Balcones Dr. Suite 202

Austin, Texas 78731 USA

(512) 454.0679
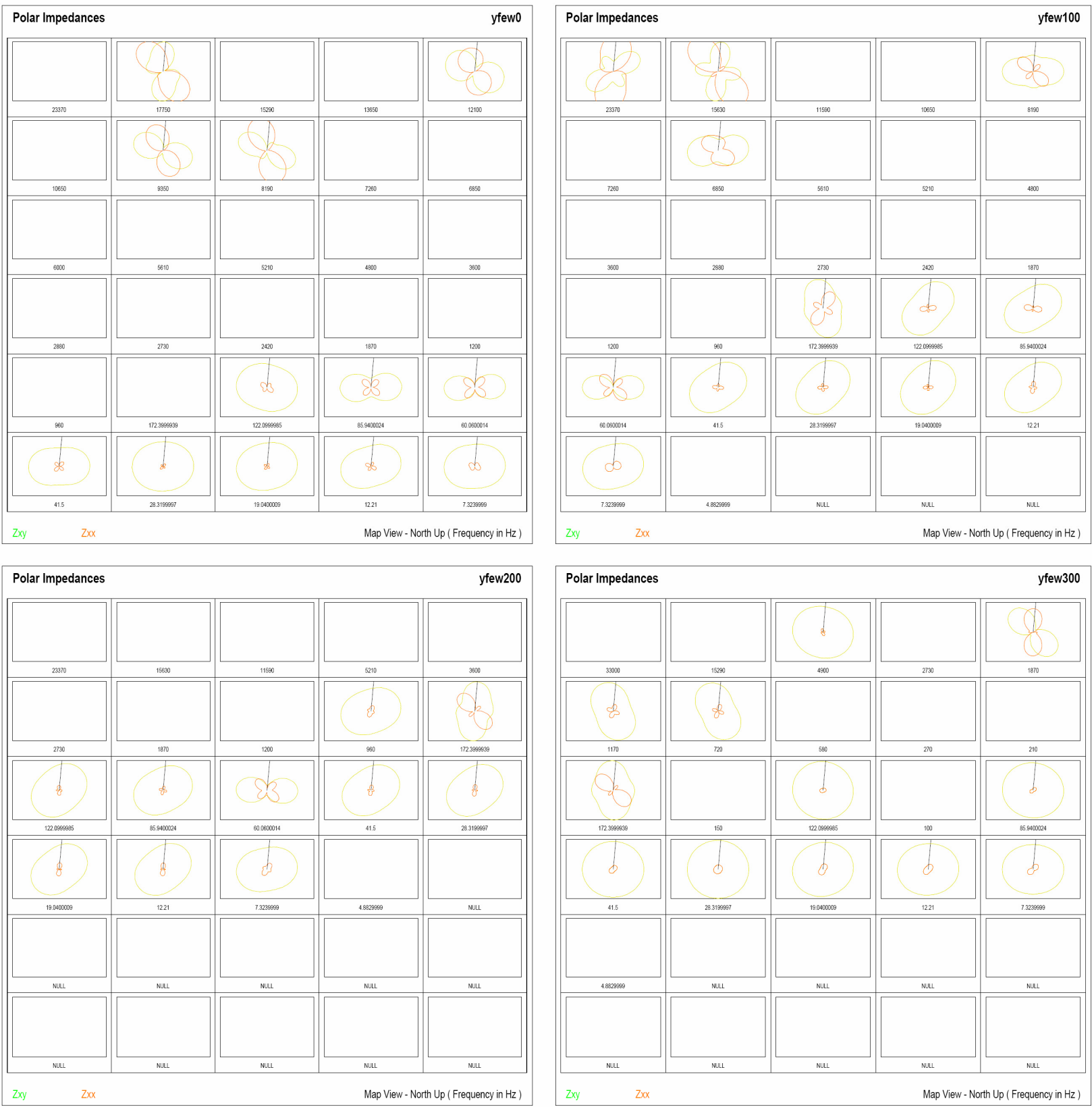

Figure B-21. Polar impedance plots for 2005 east-west line, YFRESEW, sites 1 to 4. 


\section{U.S. Geological Survey}

Denver Federal Center

Denver, Colorado 80225

MT Data for: YFFC05

Date: 09/18/08
平Geotools

by

Geotools Corporation

5808 Balcones Dr. Suite 202

Austin, Texas 78731 USA

(512) 454-0679
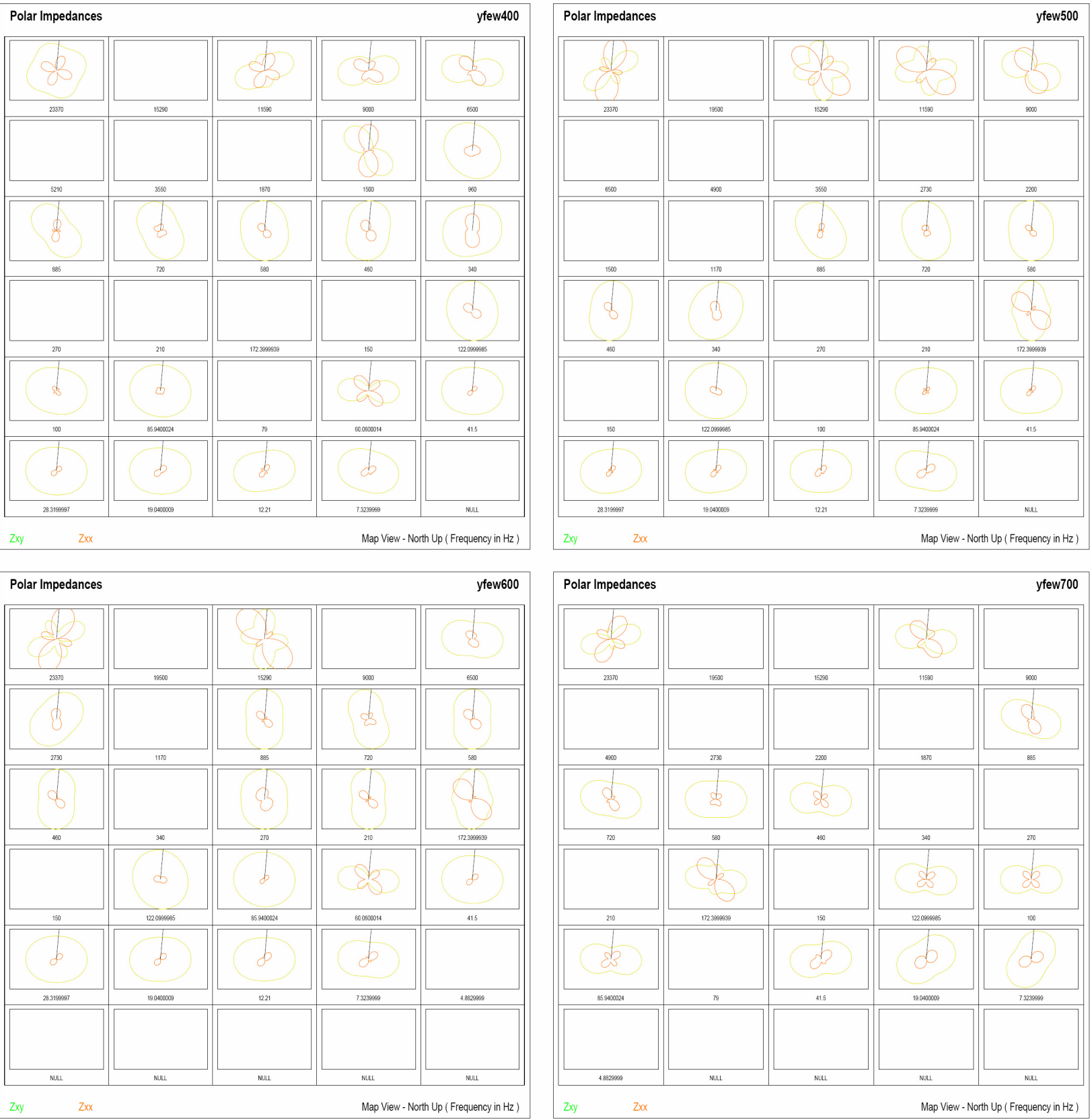

Figure B-22. Polar impedance plot for 2005 east-west line, YFRESEW, sites 5 to 8. 


\section{U.S. Geological Survey}

Denver Federal Center

Denver, Colorado 80225

MT Data for: YFFC05

Date: 09/18/08
垂Geotools

by

Geotools Corporation

5808 Balcones Dr. Suite 202

Austin, Texas 78731 USA

(512) 454-0679
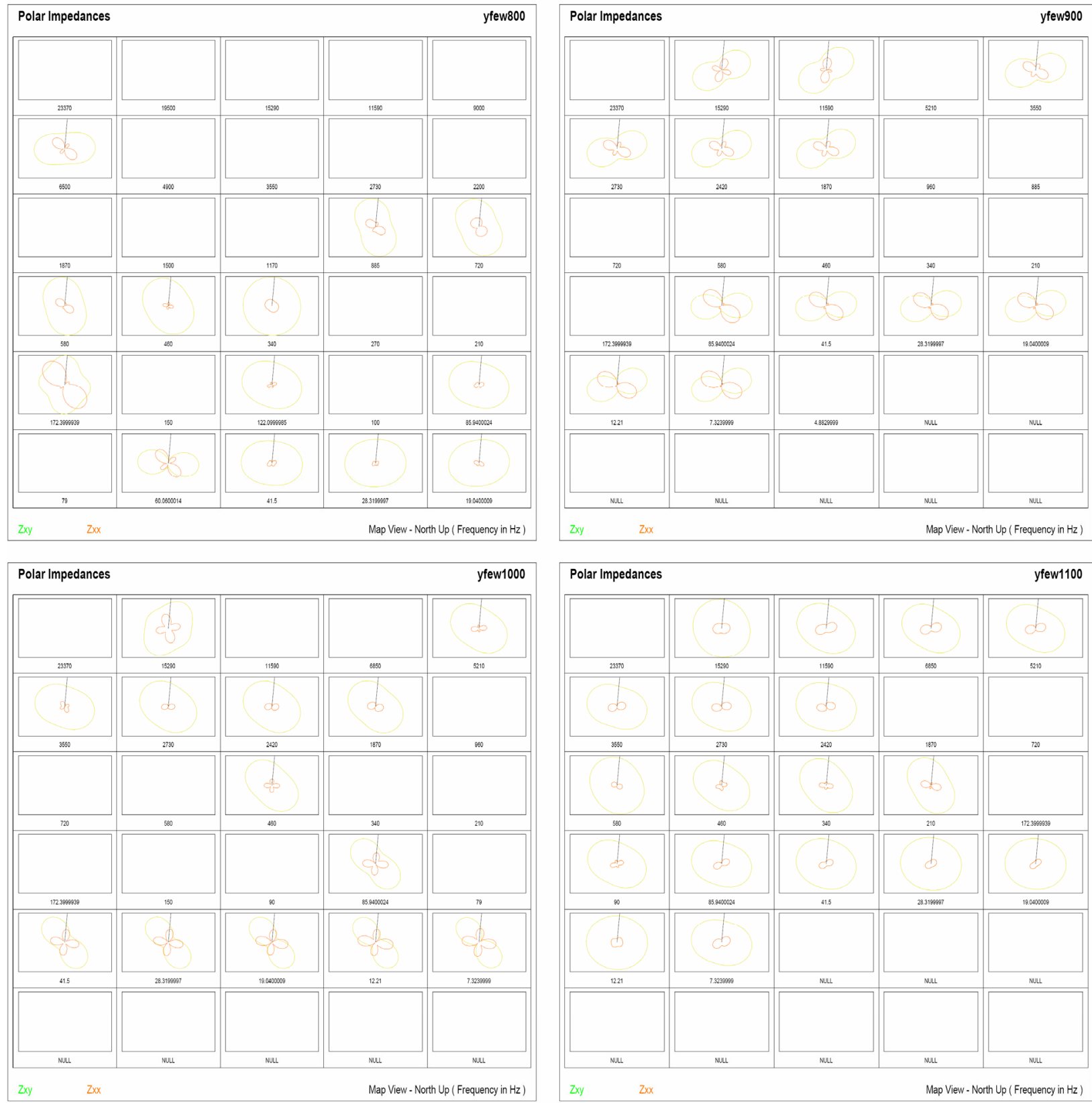

Figure B-23. Polar impedance plots for 2005 east-west line, YFRESEW, sites 9 to 12. 


\section{U.S. Geological Survey}

Denver Federal Center

Denver, Colorado 80225

MT Data for: YFFC05

Date: $09 / 18 / 08$

by

Geotools Corporation 5808 Balcones Dr. Suite 202 Austin, Texas 78731 USA (512) 454.0679
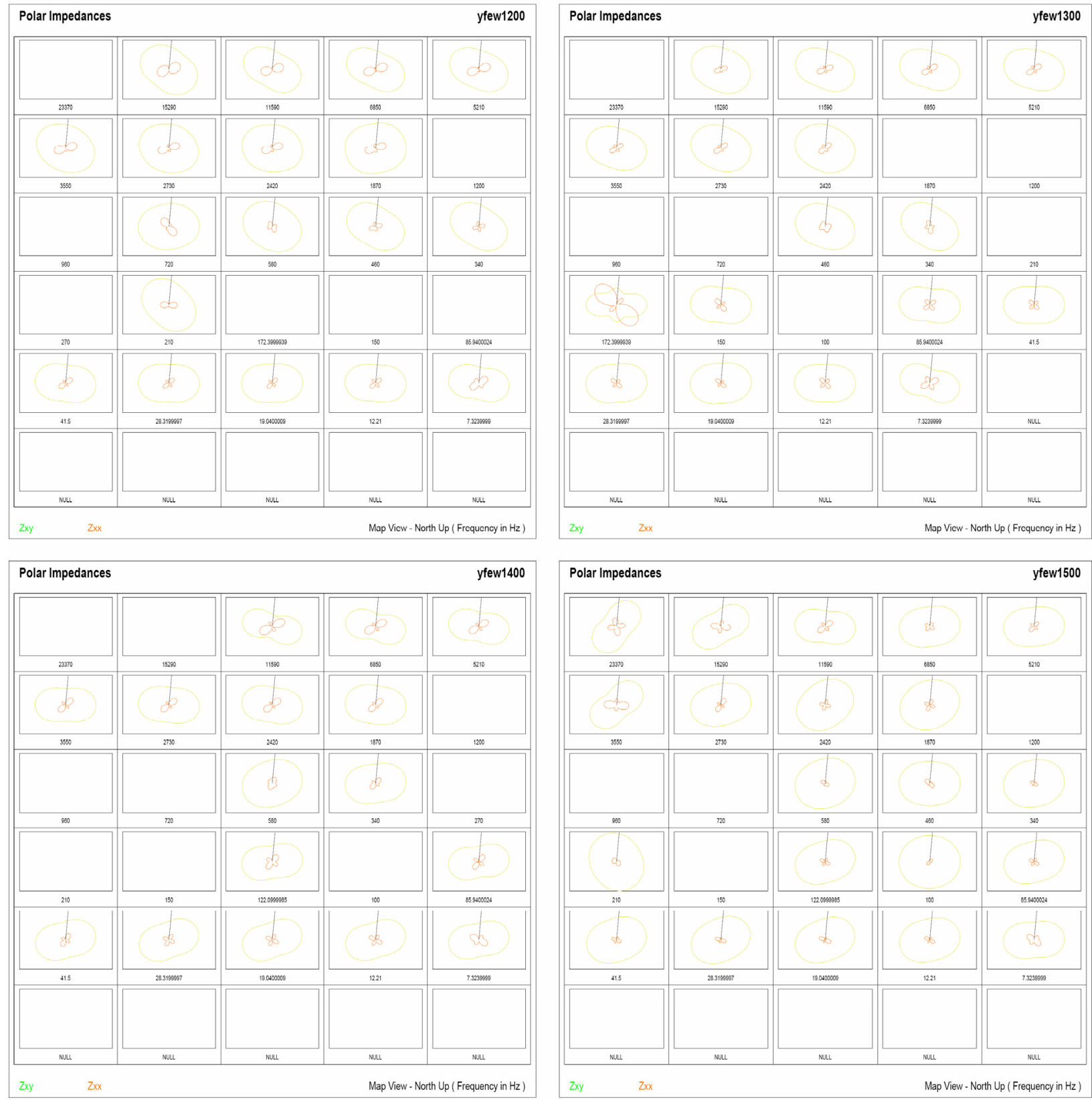

Figure B-24. Polar impedances for 2005 east-west line, YFRESEW, sites 13 to 16. 


\section{U.S. Geological Survey}

Denver Federal Center

Denver, Colorado 80225

MT Data for: YFFC05

Date: 09/18/08
FGeotools

by

Geotocols Corpration

5008 Balocnes Dr. Silite 202

Ausin, Texas 78731 USA

(512) 4540678
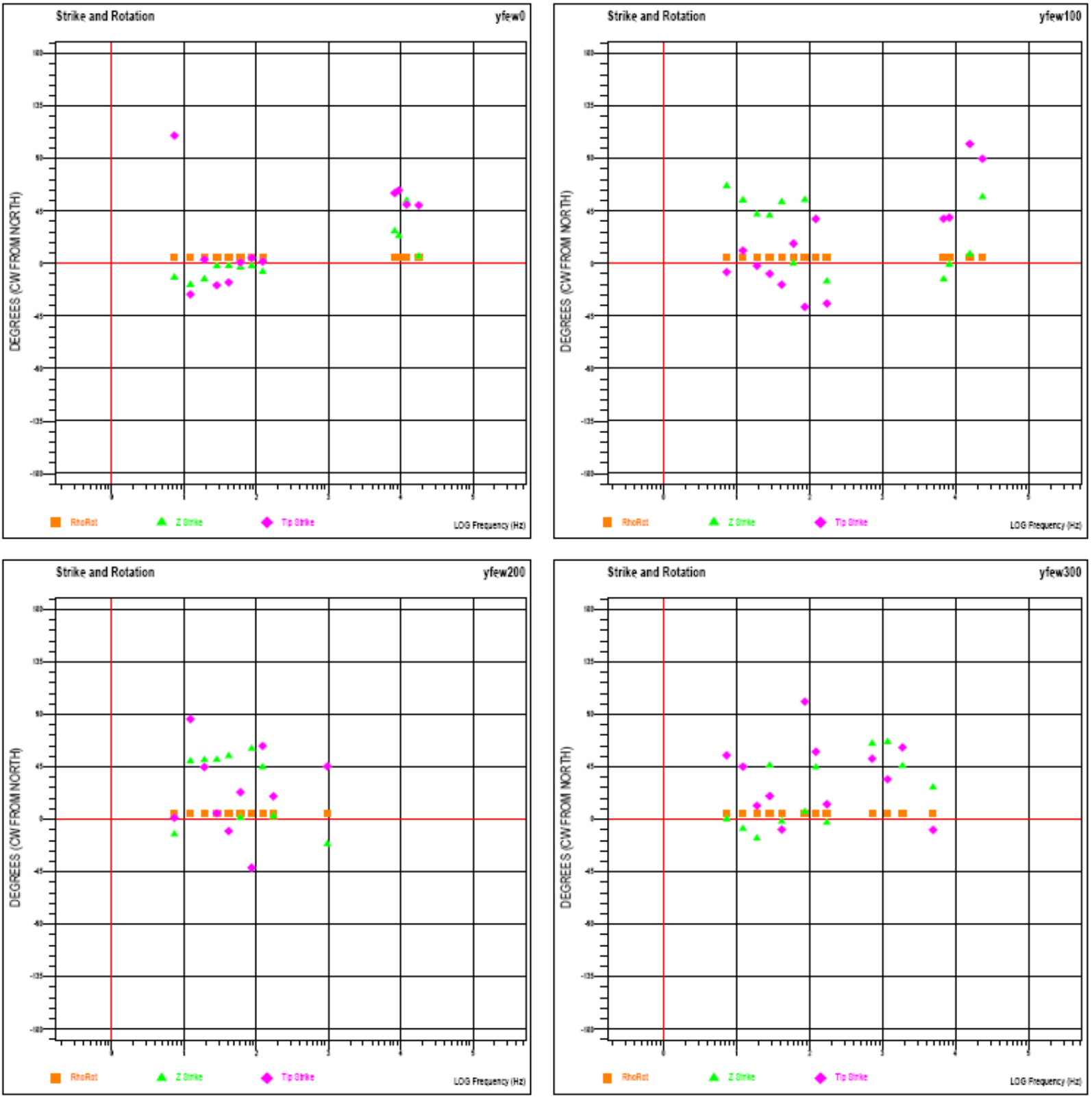

Figure B-25. Impedance strike and rotation angle and tipper strike for 2005 east-west line, YFRESEW, sites 1 to 4 . 


\section{U.S. Geological Survey}

Denver Federal Center

Denver, Colorado 80225

MT Data for: YFFC05

Date: 09/18/08

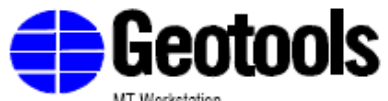

MT Workstation

by

Geotools Corporation

5008 Balcones Dr. Suite 202

Austin, Texas 78731 USA

(512) 454.0679
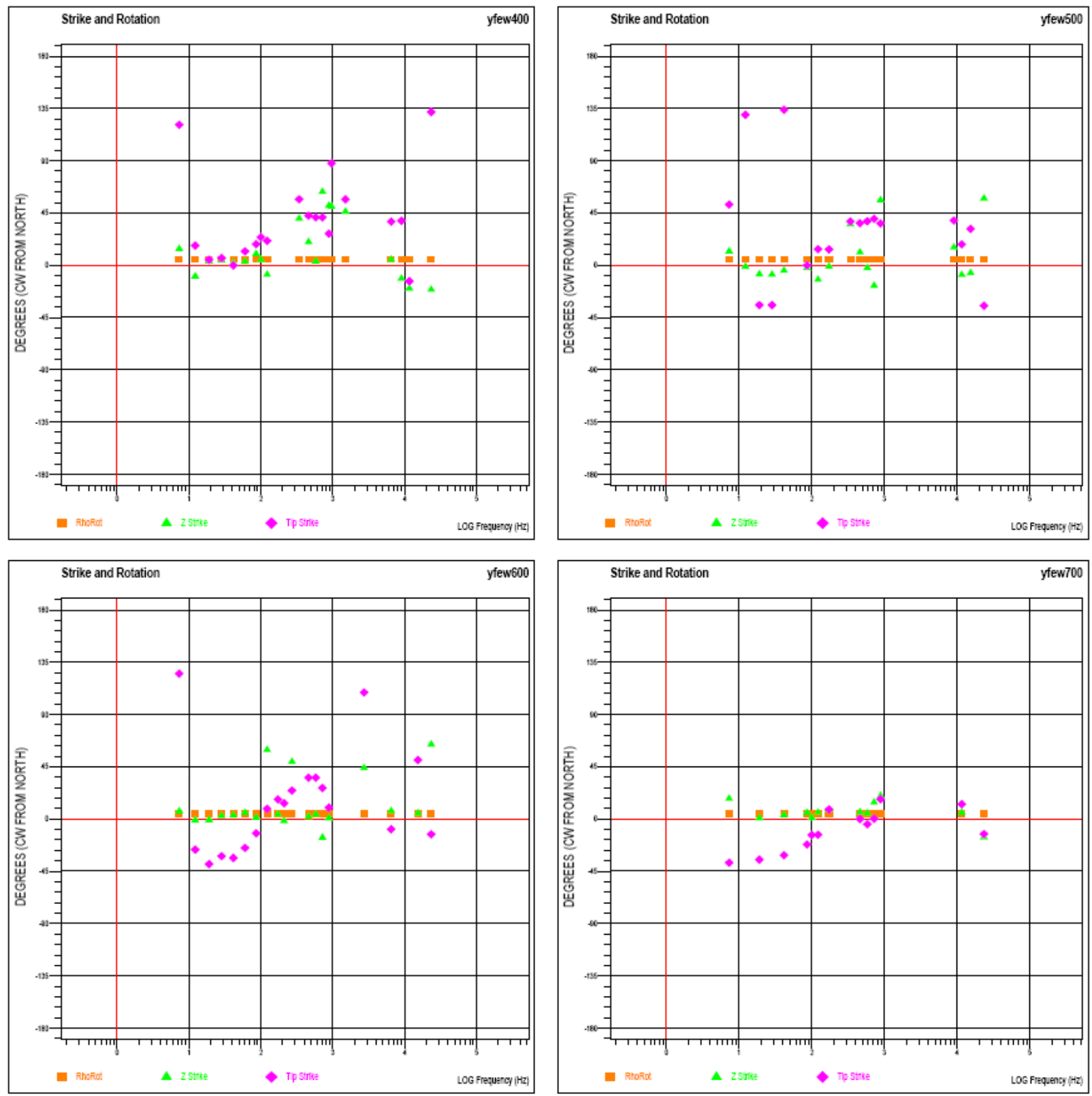

Figure B-26. Impedance strike and rotation angle and tipper strike for 2005 east-west line, YFRESEW, sites 5 to 8 . 


\section{U.S. Geological Survey}

Denver Federal Center

Denver, Colorado 80225

MT Data for: YFFC05

Date: 09/18/08
F Geotools

by

Geobsols Copration

5020 Bacones or. Sirle 2020

Ausfin, Texas 78731 USA

(512) 45456078
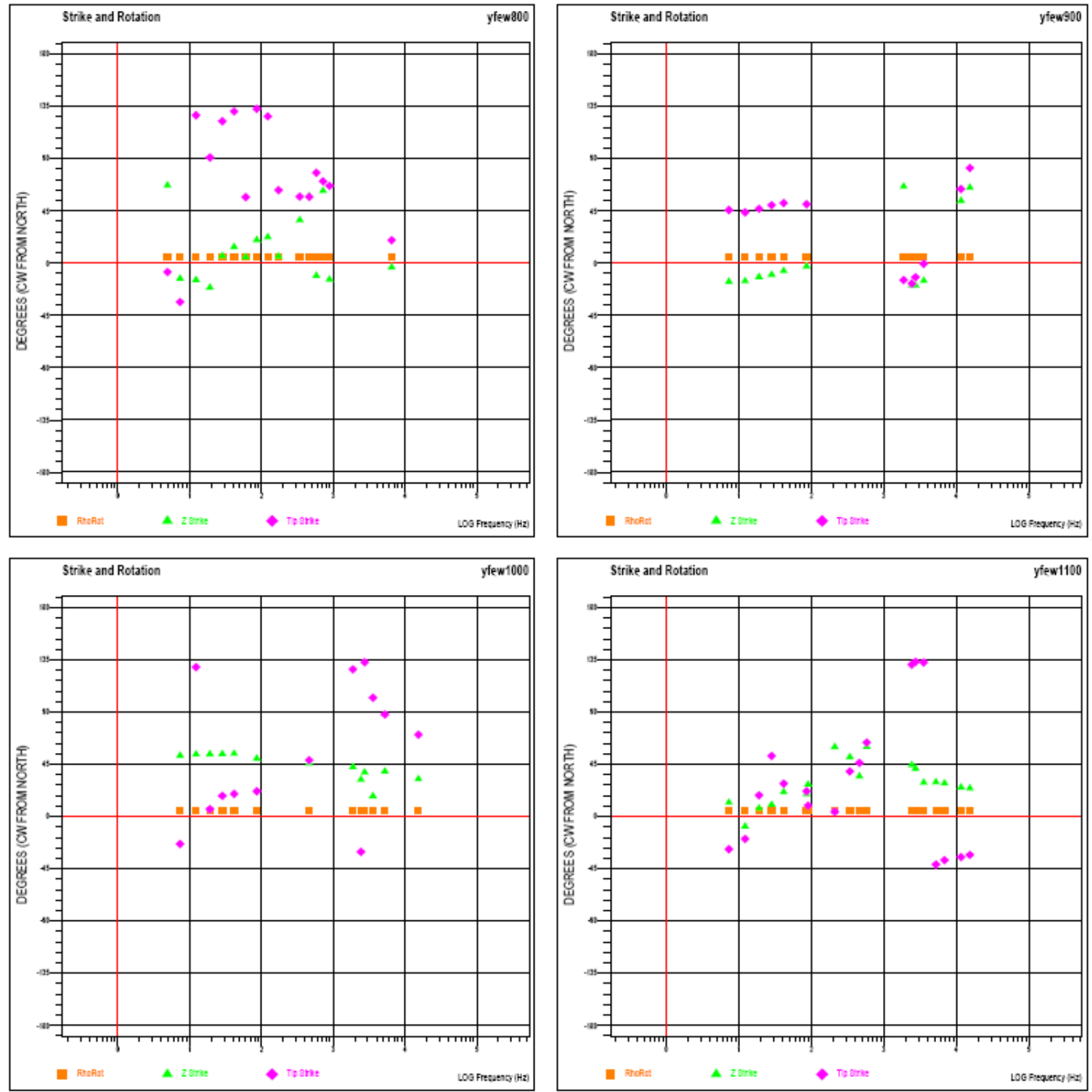

Figure B-27. Impedance strike and rotation angle and tipper strike for 2005 east-west line, YFRESEW, sites 9 to 12 . 


\section{U.S. Geological Survey}

Denver Federal Center

Denver, Colorado 80225

MT Data for: YFFC05

Date: 09/18/08
平Geotools

by

Geotools Coppration

5008 Babcones Dr. Slite 202

Ausin Texas 78731 USA

(512) 4540678
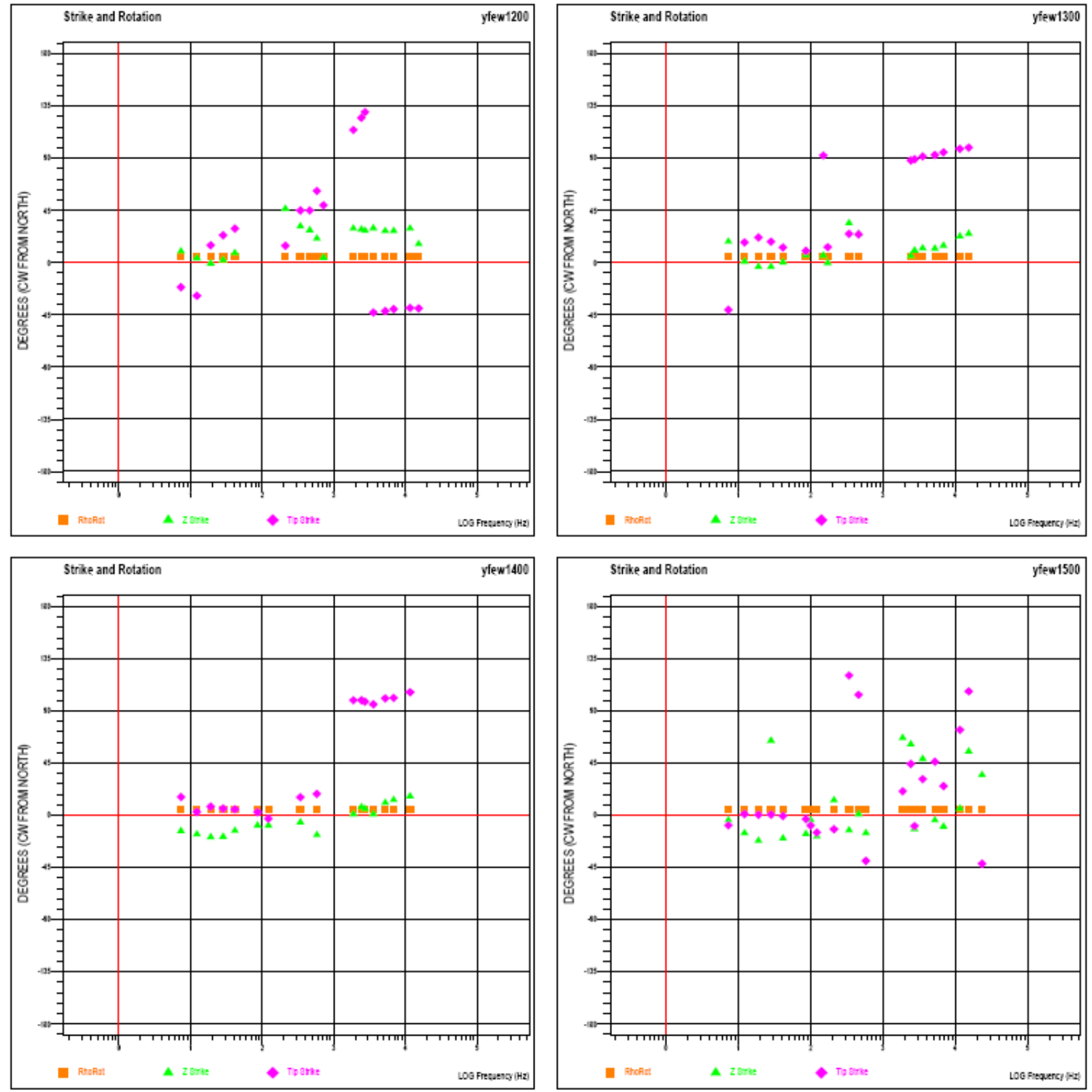

Figure B-28. Impedance strike and rotation angle and tipper strike for 2005 east-west line, YFRESEW, sites 13 to 16 . 


\section{Interpretations R Us}

1234 Main Street

Anytown, State 12345

MT Data for: yffc05ns

Date: 09/24/08

\section{拝Geotools \\ MT Workstation}

by

Geotools Corporation 5808 Balcones Dr. Suite 202 Austin, Texas 78731 USA

(512) 454-0679

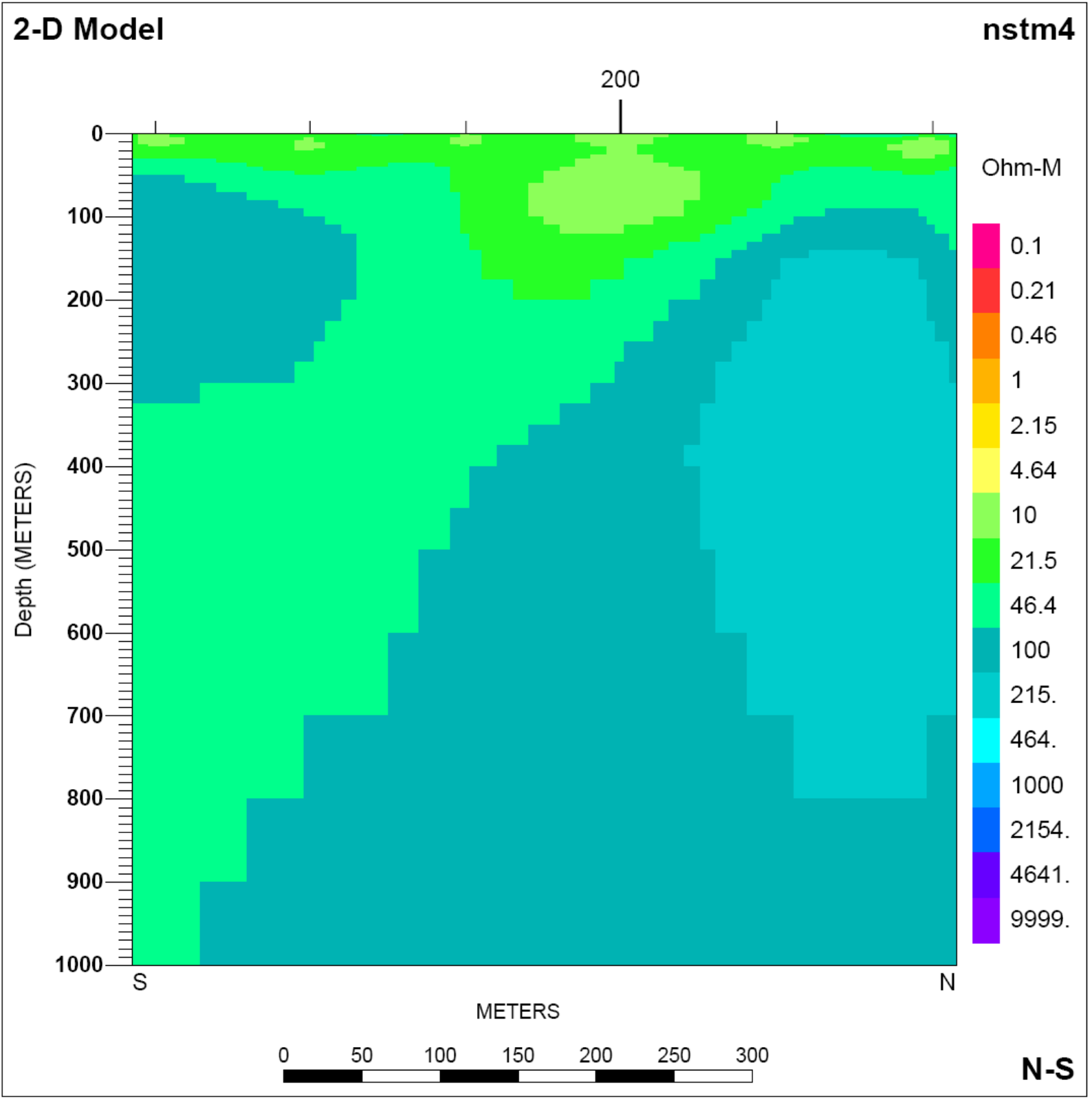

Figure B-29. Two-dimensional inversion model for 2005 north-south line, YFRESNS. without the finite difference mesh. 


\section{Interpretations R Us}

1234 Main Street

Anytown, State 12345

\section{MT Data for: yffc05ns}

Date: 09/24/08

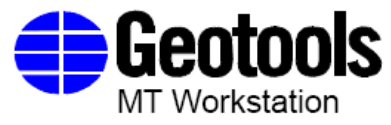

by

Geotools Corporation 5808 Balcones Dr. Suite 202

Austin, Texas 78731 USA

(512) 454-0679

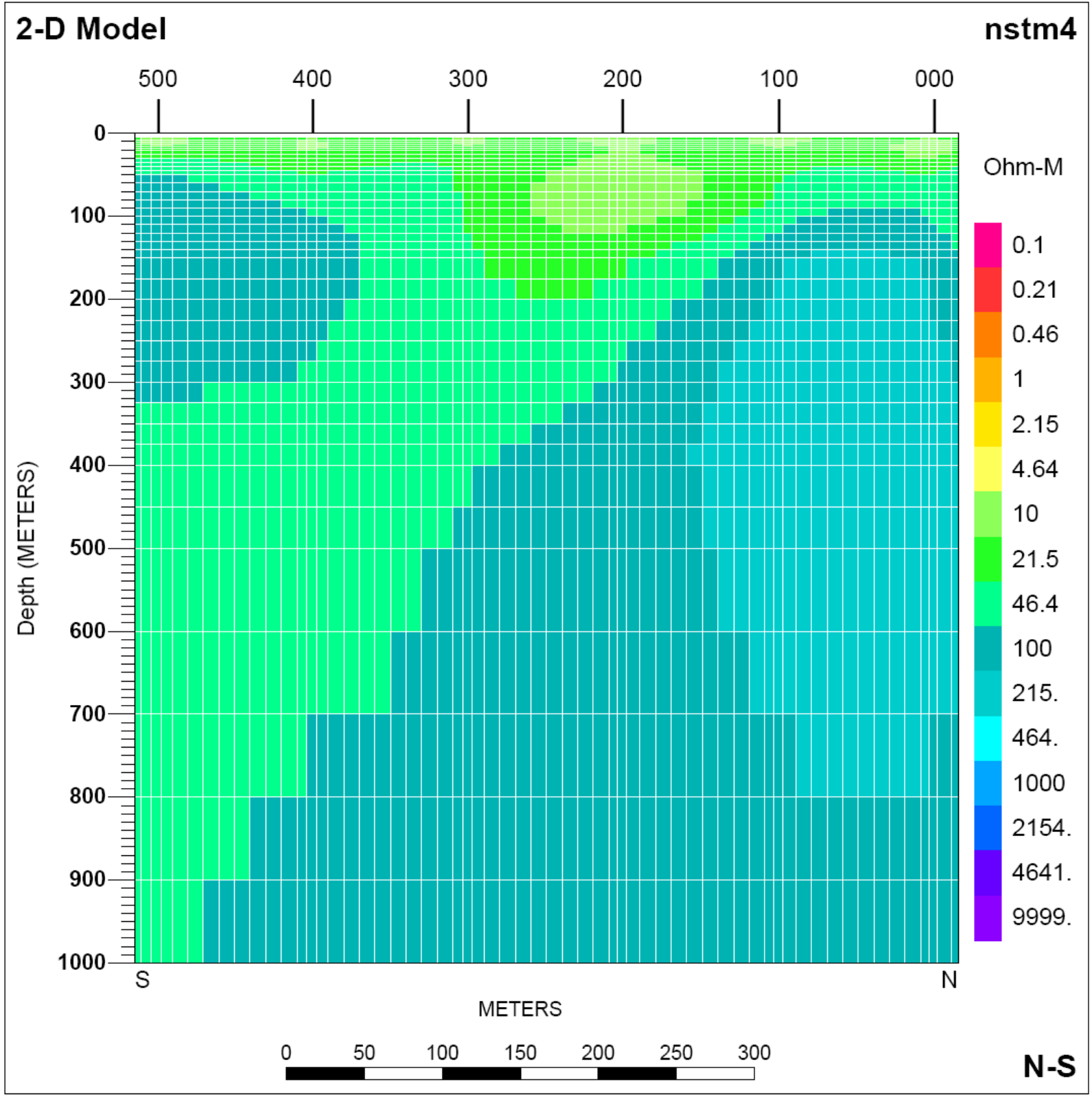

Figure B-30. 7Z R \pm GP HQMRQDOforward and inversion model for 2005 north-south line, YFRESNS. with mesh. 


\section{Interpretations R Us}

1234 Main Street

Anytown, State 12345

\section{MT Data for: yffc05ns}

Date: $09 / 24 / 08$

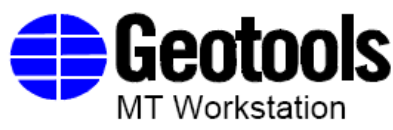

by

Geotools Corporation

5808 Balcones Dr. Suite 202

Austin, Texas 78731 USA

(512) 454-0679
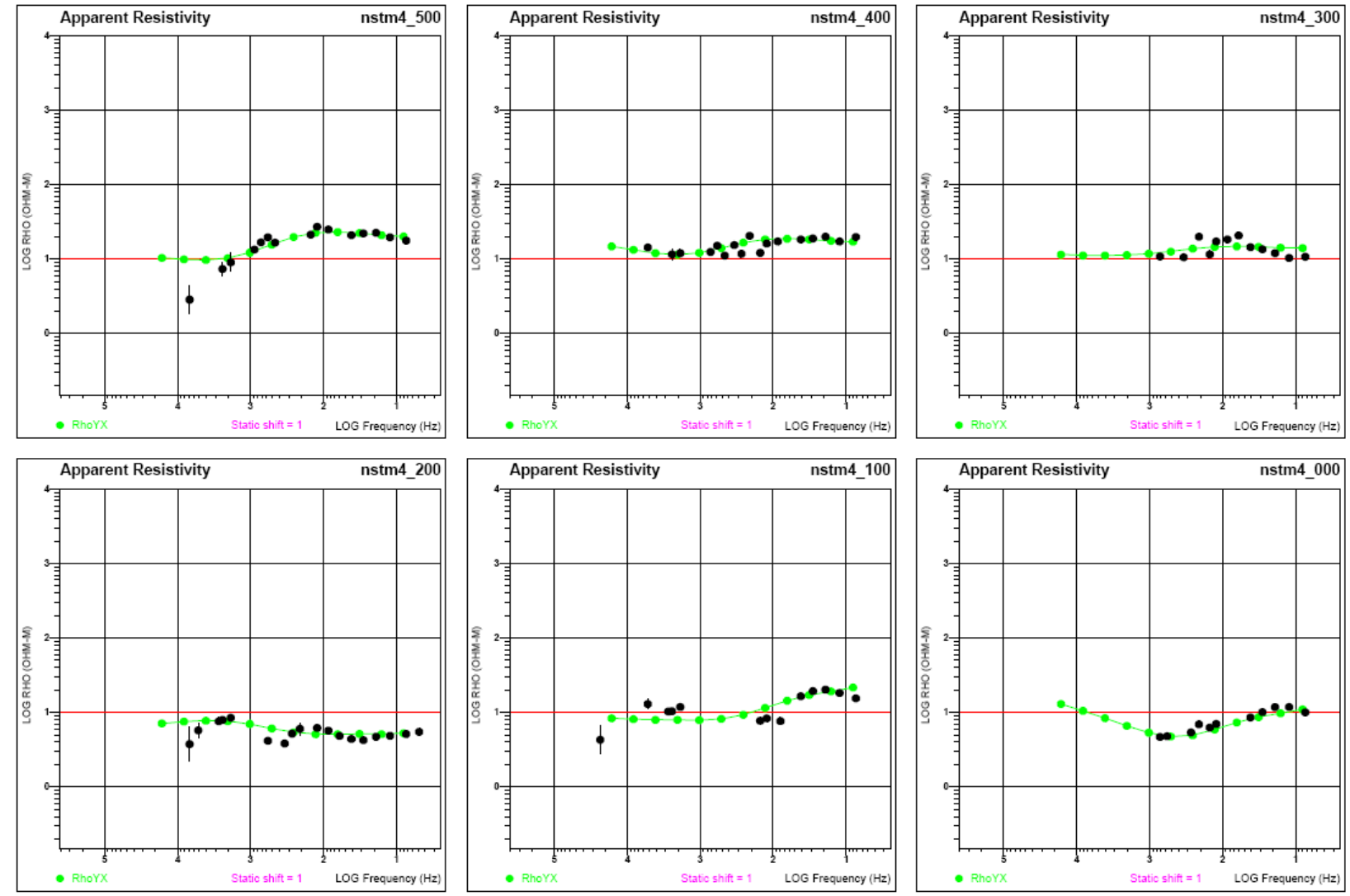

Figure B-31. Apparent resistivity field and model data for 2005 north-south line, YFRESNS, sites 1 to 6 . 
Interpretations R Us

1234 Main Street

Anytown, State 12345

\section{MT Data for: yffc05ns}

Date: 09/24/08
Geotools

MT Workstation

by

Geotools Corporation 5808 Balcones Dr. Suite 202 Austin, Texas 78731 USA (512) 454-0679
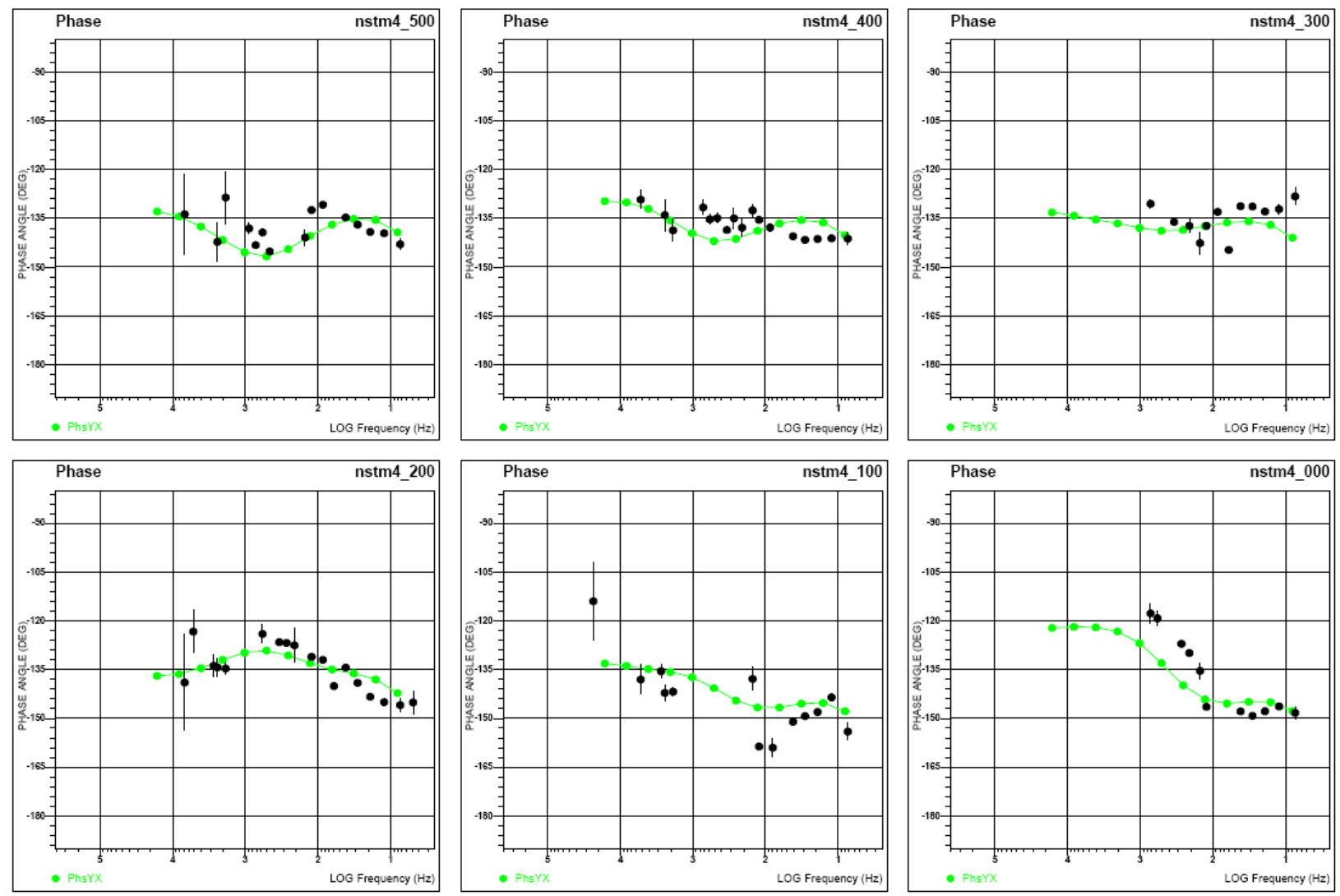

Figure B-32. Impedance phase field and model data for 2005 north-south line, YFRESNS, sites 1 to 6 . 


\section{Interpretations R Us}

1234 Main Street

Anytown, State 12345

\section{MT Data for: yffc05ns}

Date: 09/24/08

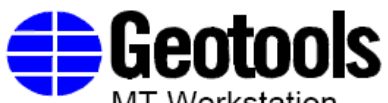

MT Workstation

by

Geotools Corporation

5808 Balcones Dr. Suite 202

Austin, Texas 78731 USA

(512) 454-0679
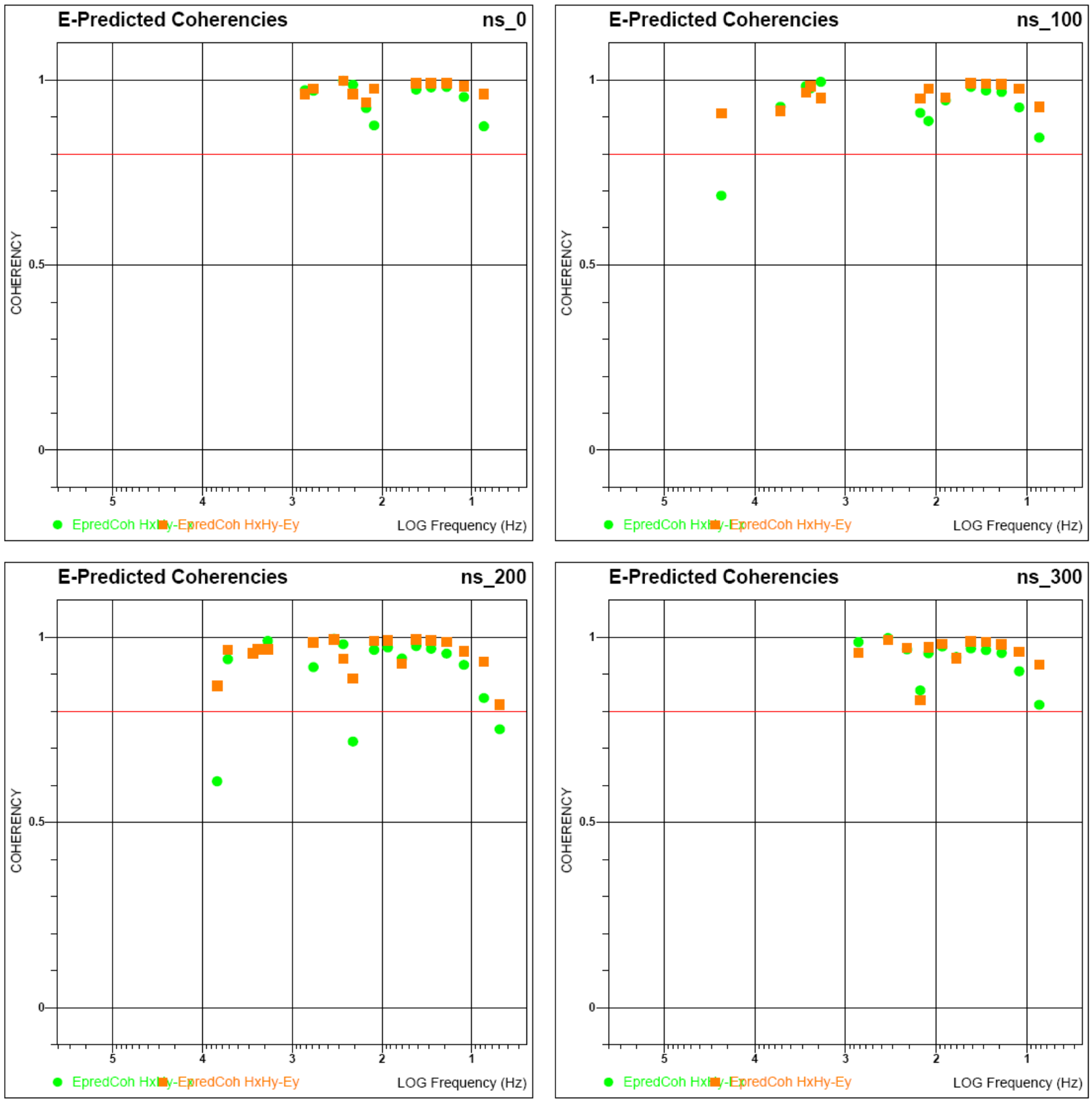

Figure B-33. Coherency data for 2005 north-south line, YFRESNS, sites 1 to 4. 
Interpretations R Us

1234 Main Street

Anytown, State 12345

MT Data for: yffc05ns

Date: 09/24/08

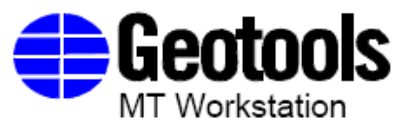

by

Geotools Corporation 5808 Balcones Dr. Suite 202 Austin, Texas 78731 USA

(512) 454-0679
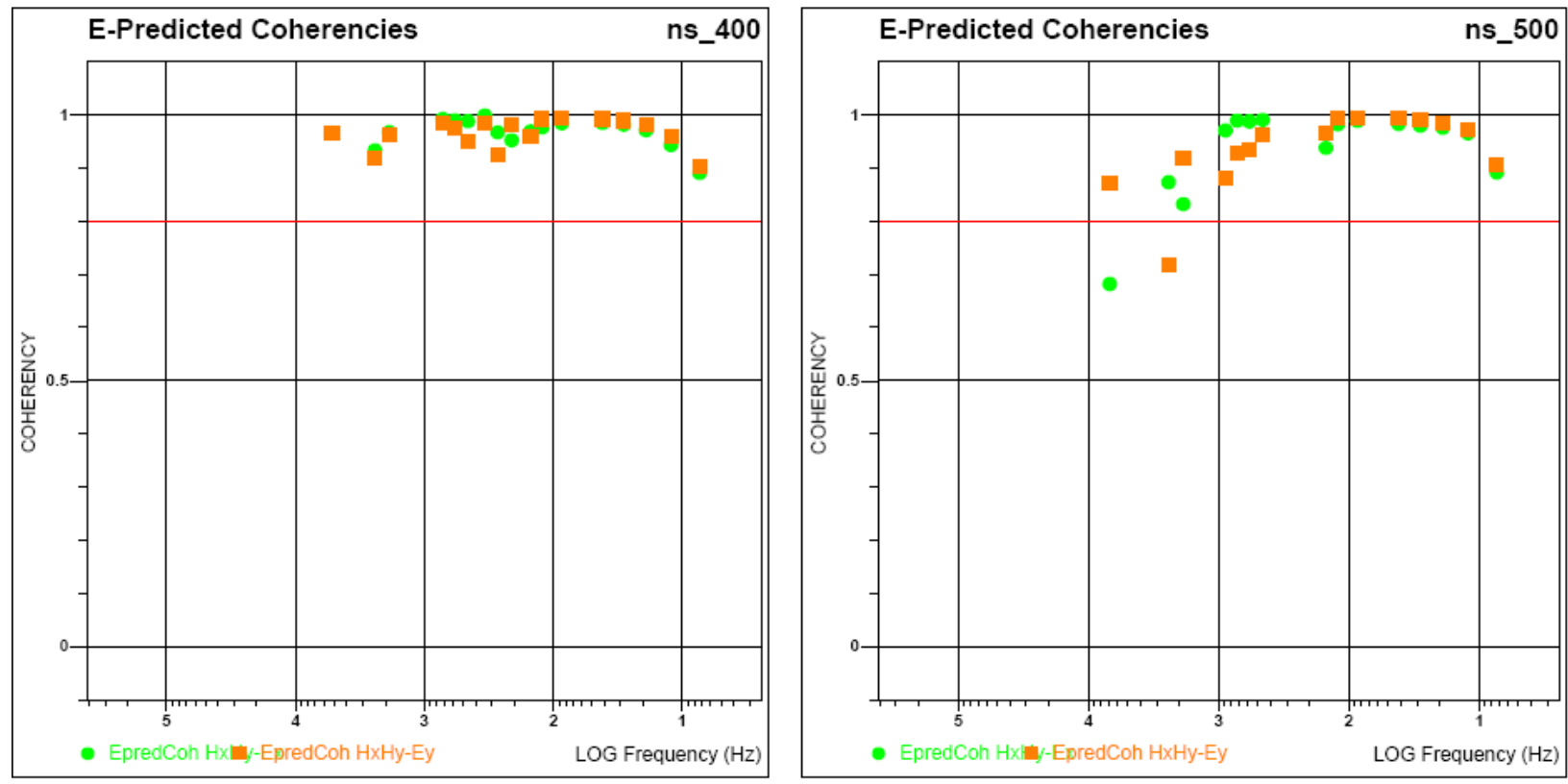

Figure B-34. Coherency data for 2005 north-south line, YFRESNS, sites 5 to 6. 


\section{Interpretations R Us}

1234 Main Street

Anytown, State 12345

\section{MT Data for: yffc05ns}

Date: 09/24/08
車Geotools MT Workstation

by

Geotools Corporation 5808 Balcones Dr. Suite 202 Austin, Texas 78731 USA

(512) 454-0679
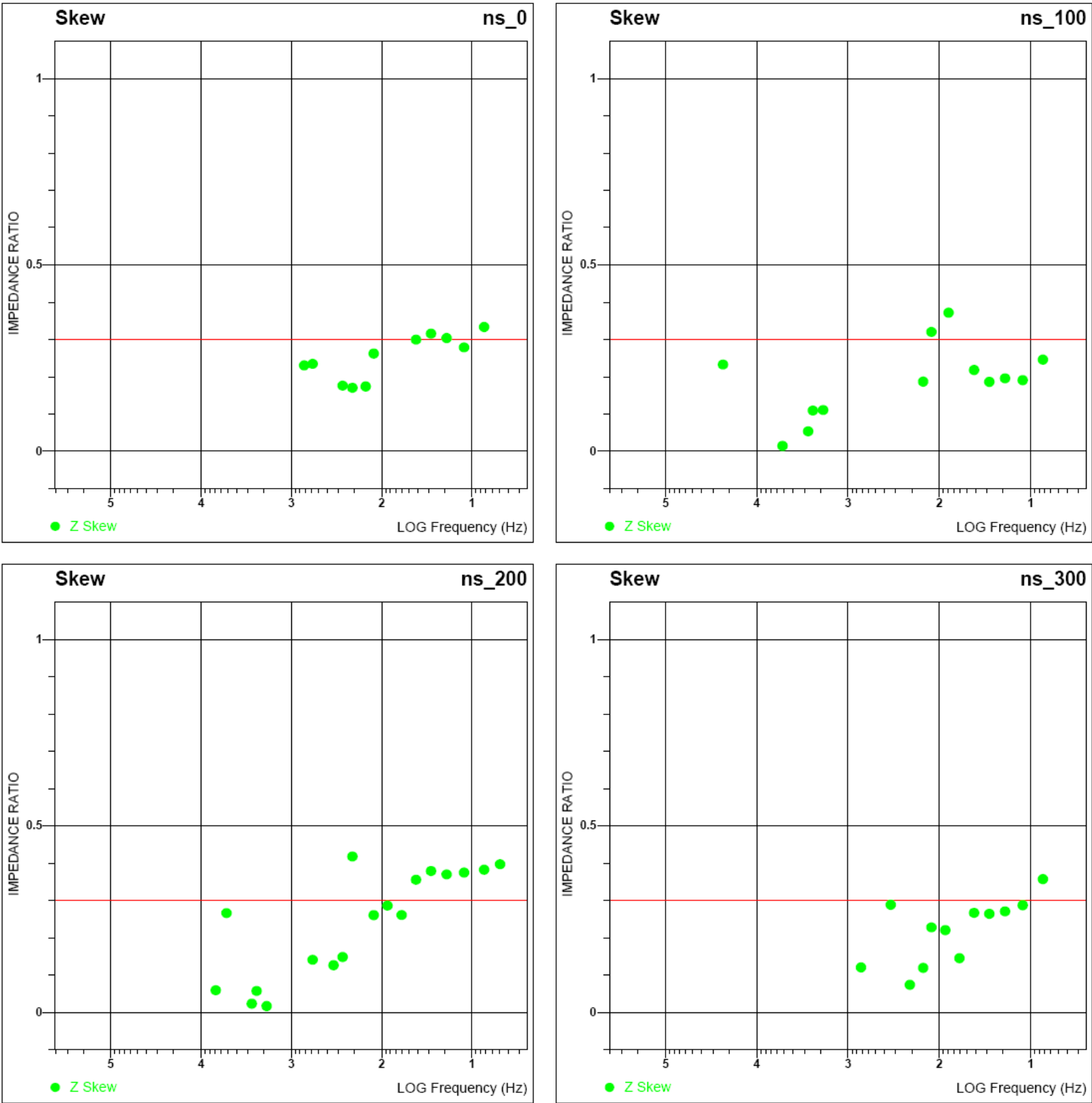

Figure B-35. Impedance skew data for 2005 north-south line, YFRESNS, sites 1 to 4. 


\section{Interpretations R Us}

1234 Main Street

Anytown, State 12345

\section{MT Data for: yffc05ns}

Date: 09/24/08

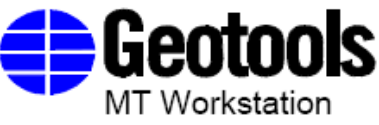

by

Geotools Corporation 5808 Balcones Dr. Suite 202 Austin, Texas 78731 USA

(512) 454-0679
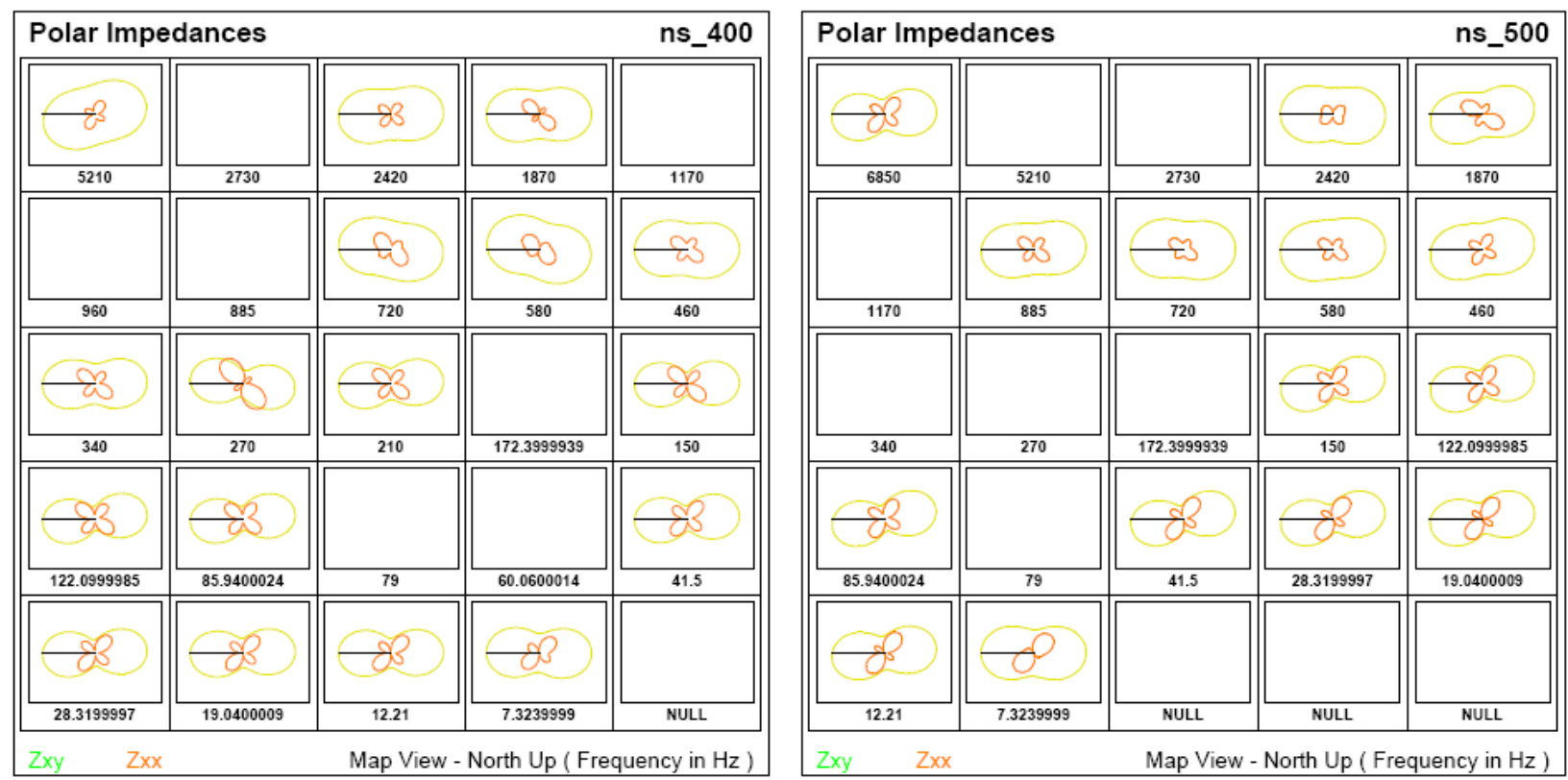

Figure B-36. Impedance skew data for 2005 north-south line, YFRESNS, sites 5 to 6. 


\section{Interpretations R Us}

1234 Main Street

Anytown, State 12345

\section{MT Data for: yffc05ns}

Date: 09/24/08
Geotools

MT Workstation

by

Geotools Corporation

5808 Balcones Dr. Suite 202

Austin, Texas 78731 USA

(512) 454-0679
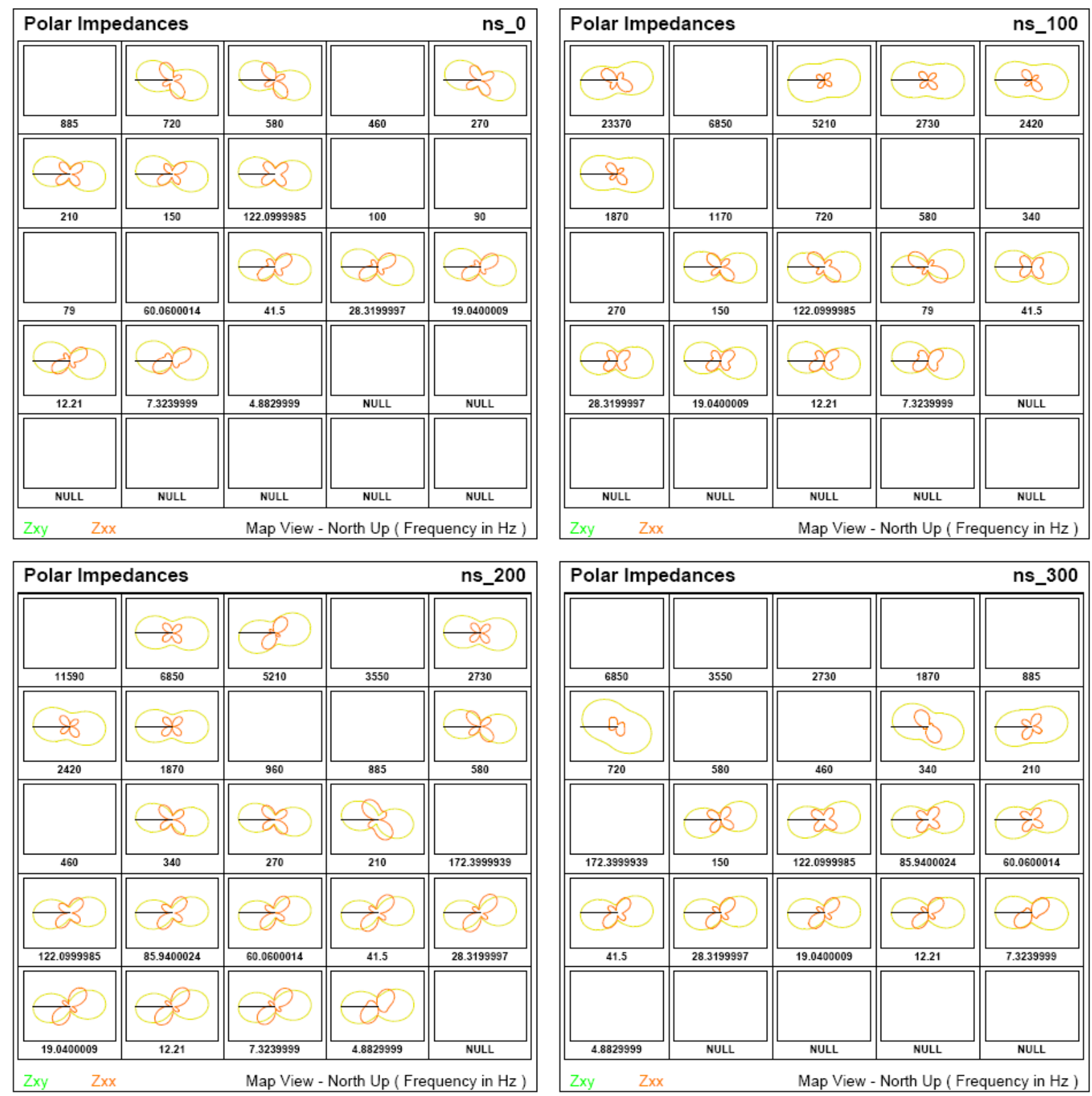

Figure B-37. Polar impedance plots for 2005 north-south line, YFRESNS, sites 1 to 4. 


\section{Interpretations R Us}

1234 Main Street

Anytown, State 12345

MT Data for: yffc05ns

Date: 09/24/08
拝Geotools

MT Workstation

by

Geotools Corporation

5808 Balcones Dr. Suite 202

Austin, Texas 78731 USA

(512) 454-0679
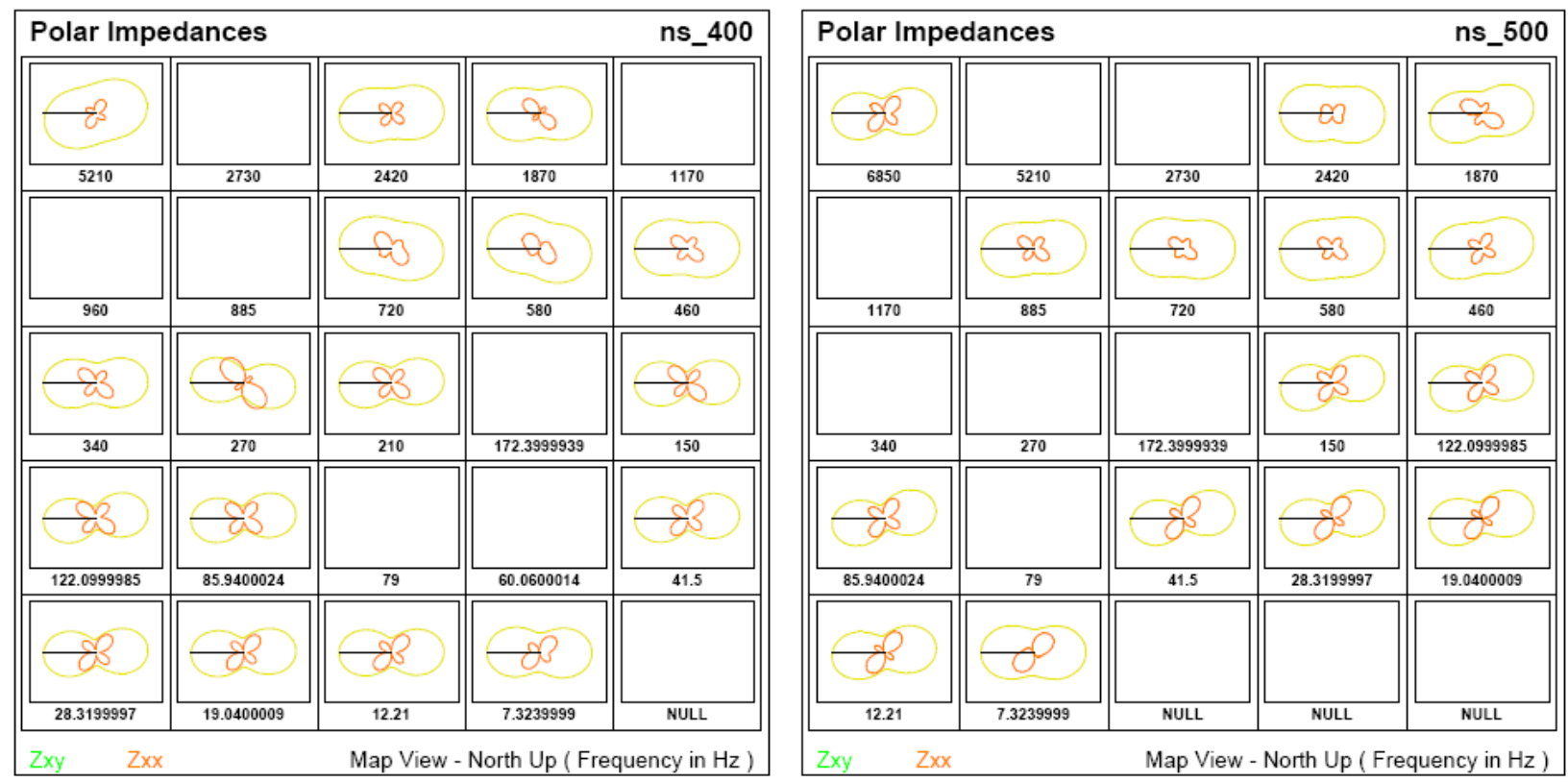

Figure B-38. Polar impedance plot for 2005 north-south line, YFRESNS, sites 5 to 6. 


\section{Interpretations R Us}

1234 Main Street

Anytown, State 12345

\section{MT Data for: yffc05ns}

Date: 09/24/08
Geotools

MT Workstation

by

Geotools Corporation 5808 Balcones Dr. Suite 202 Austin, Texas 78731 USA

(512) 454-0679
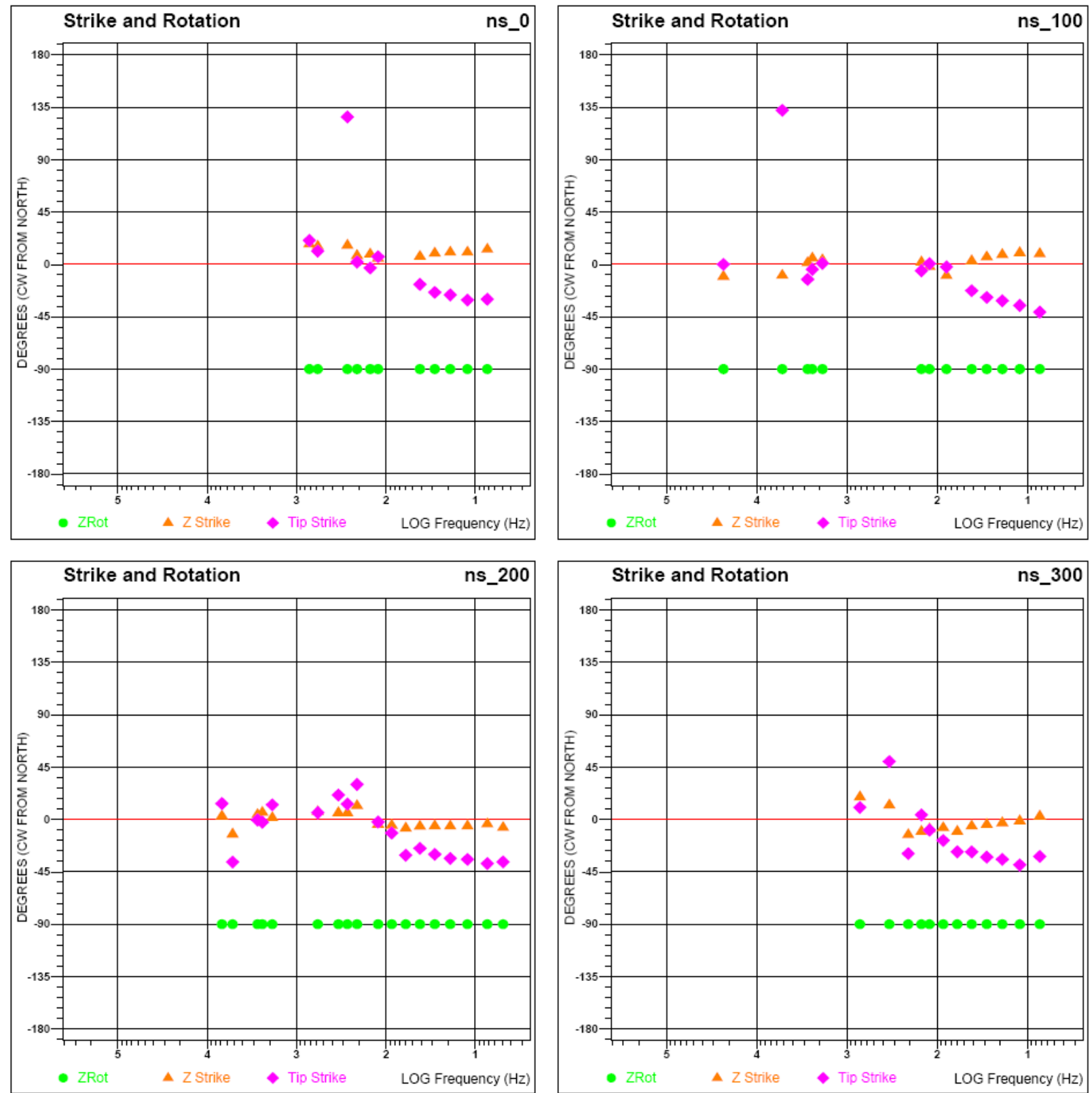

Figure B-39. Impedance strike and rotation angle and tipper strike for 2005 north-south line, YFRESNS, sites 1 to 4 . 
Interpretations R Us

1234 Main Street

Anytown, State 12345

\section{MT Data for: yffc05ns}

Date: 09/24/08
Geotools

MT Workstation

by

Geotools Corporation 5808 Balcones Dr. Suite 202 Austin, Texas 78731 USA (512) 454-0679
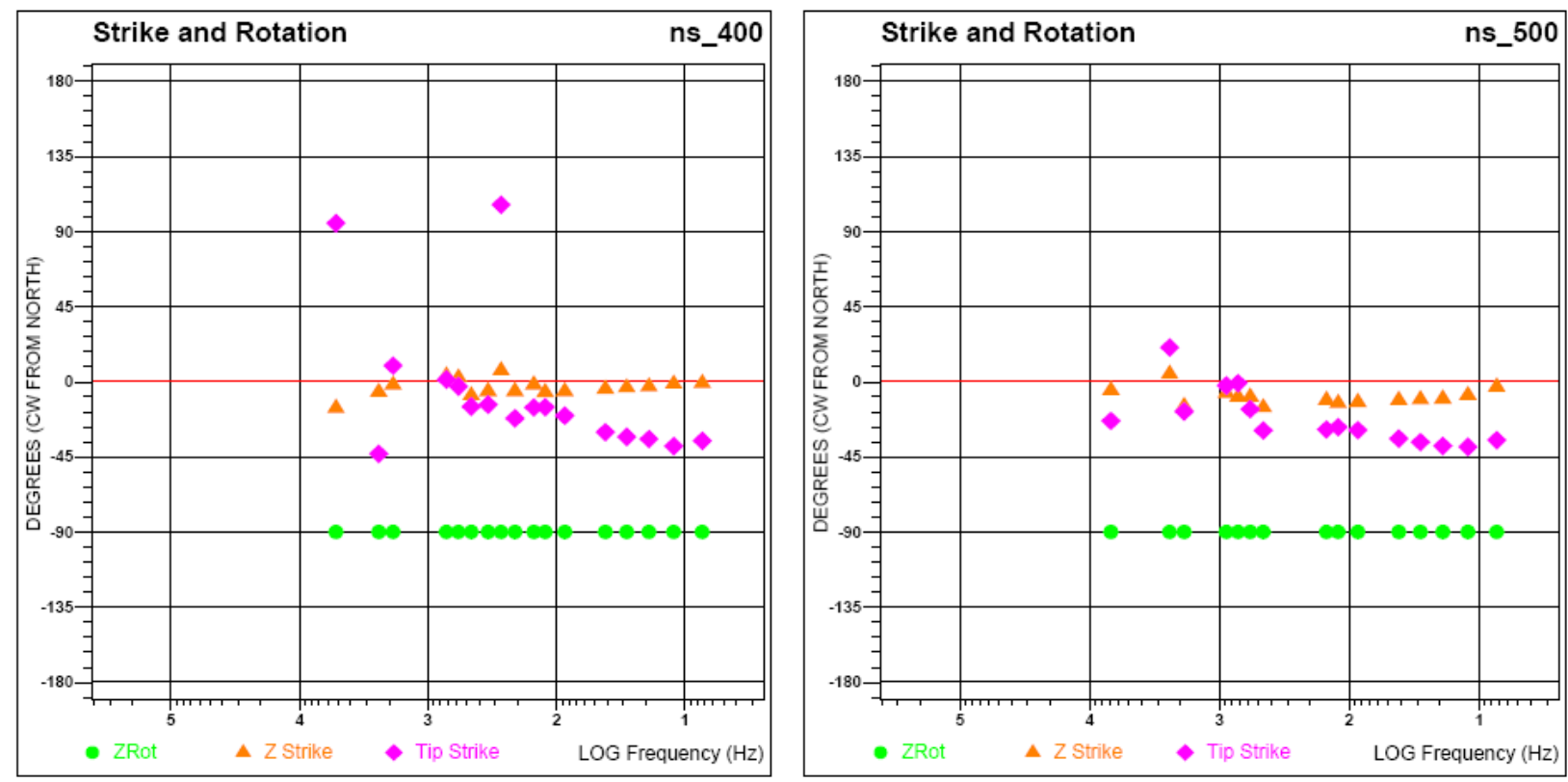

Figure B-40. Impedance strike and rotation angle and tipper strike for 2005 north-south line, YFRESNS, sites 5 to 6 . 


\section{U.S. Geological Survey}

Denver Federal Center

Denver, Colorado 80225

MT Data for: L1

Date: 09/23/08

\section{垂Geotools \\ MT Workstation}

by

Geotools Corporation

5808 Balcones Dr. Suite 202

Austin, Texas 78731 USA

(512) $454-0679$

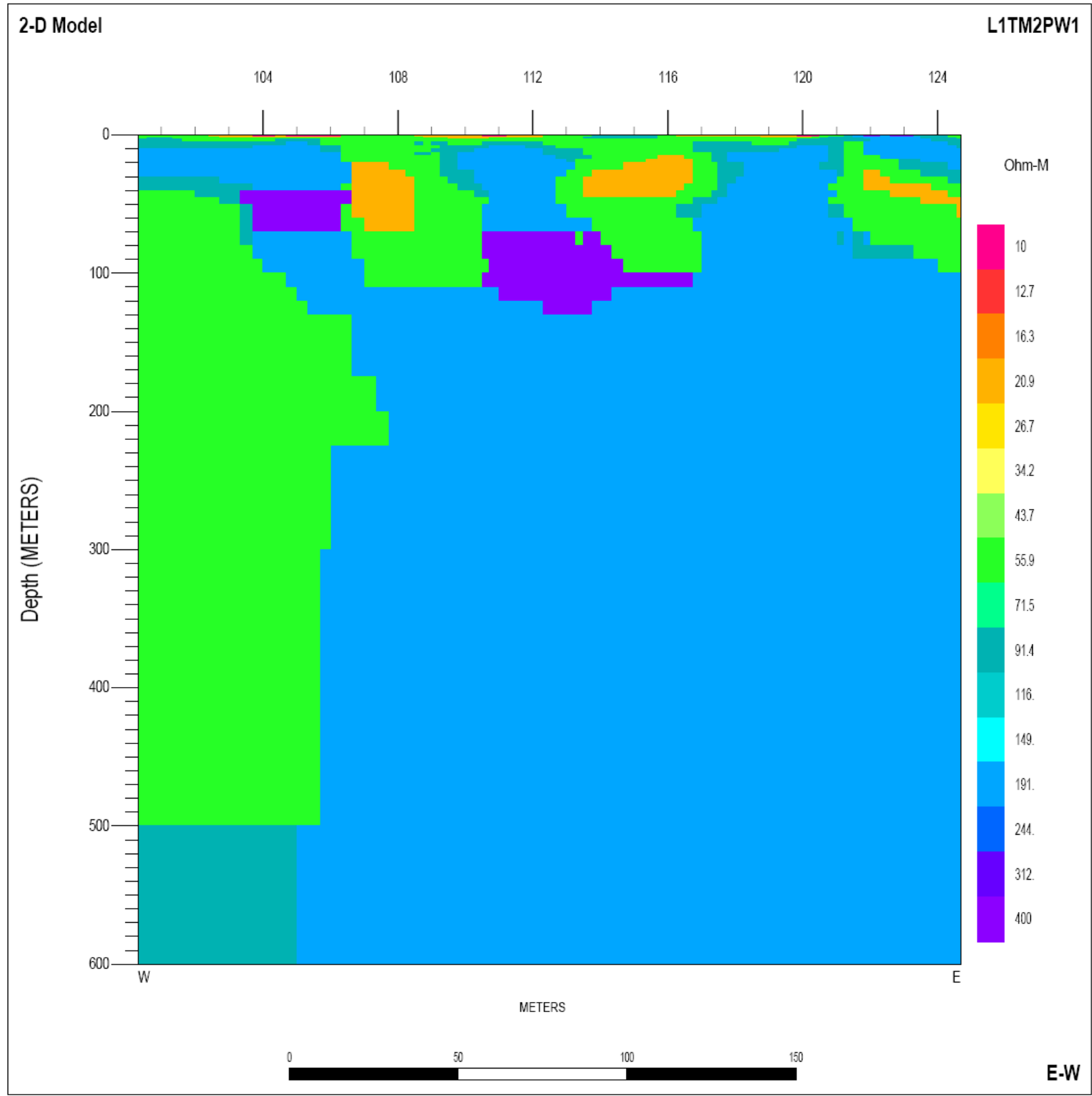

Figure B-41. Two-dimensional inversion model for 2006 Line 1, no finite difference mesh. 


\section{U.S. Geological Survey}

\section{Denver Federal Center}

Denver, Colorado 80225

MT Data for: L1

Date: $09 / 23 / 08$

\section{FGeotools \\ MT Workstation}

by

Geotools Corporation

5808 Balcones Dr. Suite 202

Austin, Texas 78731 USA

(512) 454.0679

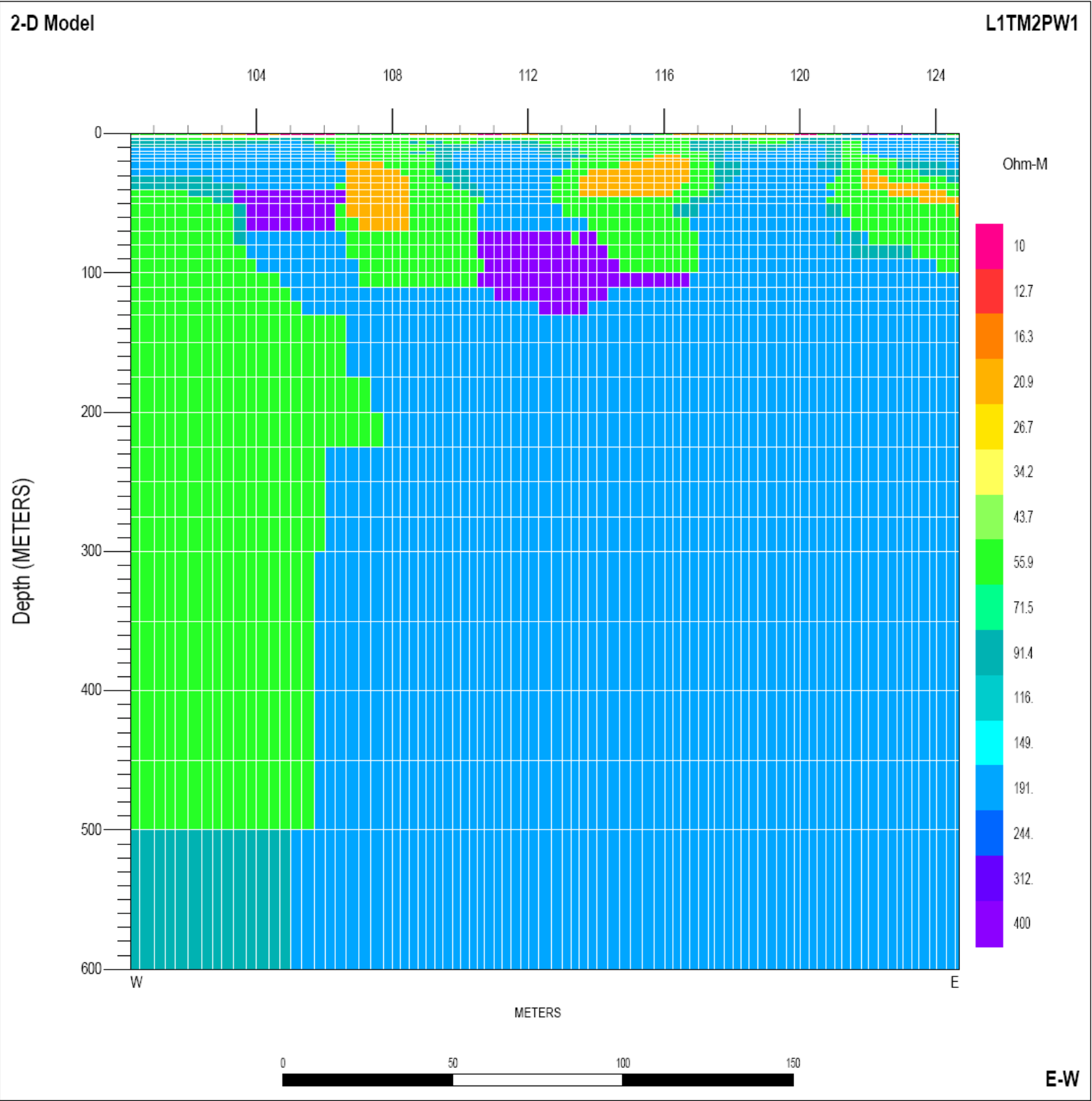

Figure B-42. Two-dimensional inversion model for 2006 Line 1 with finite difference mesh. 


\title{
U.S. Geological Survey
}

\author{
Denver Federal Center \\ Denver, Colorado 80225 \\ MT Data for: L1 \\ Date: 09/18/08
}

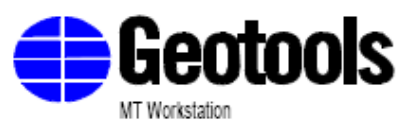

by

Gectools Corporation

5008 Belcones Dr. Sulte 202

Austin, Texes 78731 USA

(512) 454.0679
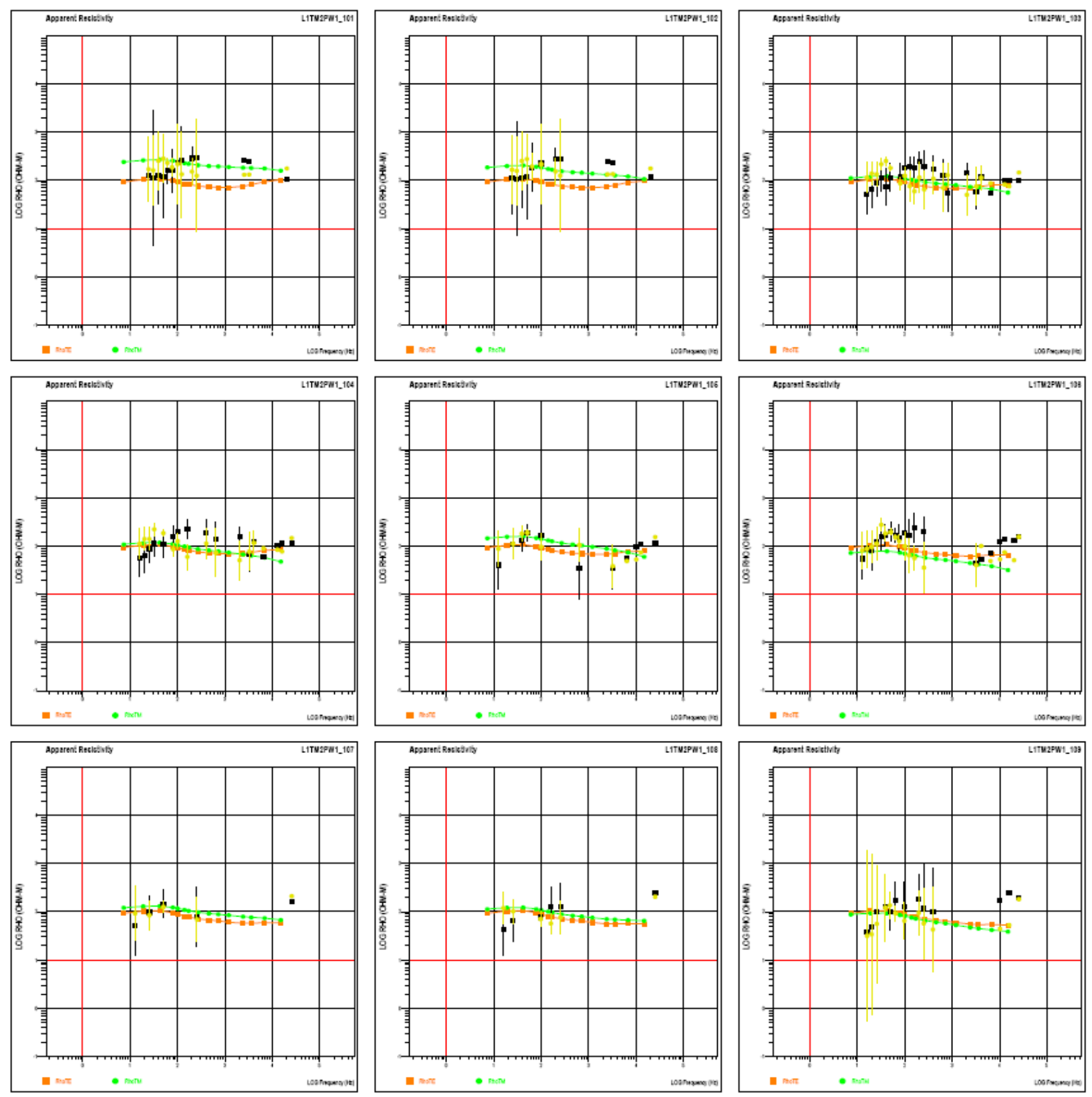

Figure B-43. Apparent resistivity data for 2006 Line 1, sites 1 to 9 . 


\section{U.S. Geological Survey}

Denver Federal Center

Denver, Colorado 80225

MT Data for: L1

Date: 09/18/08

F Geotools

by

Geotools Corporation

5808 Balcones Dr. Suite 202

Austin, Texas 78731 USA

(512) 4540679
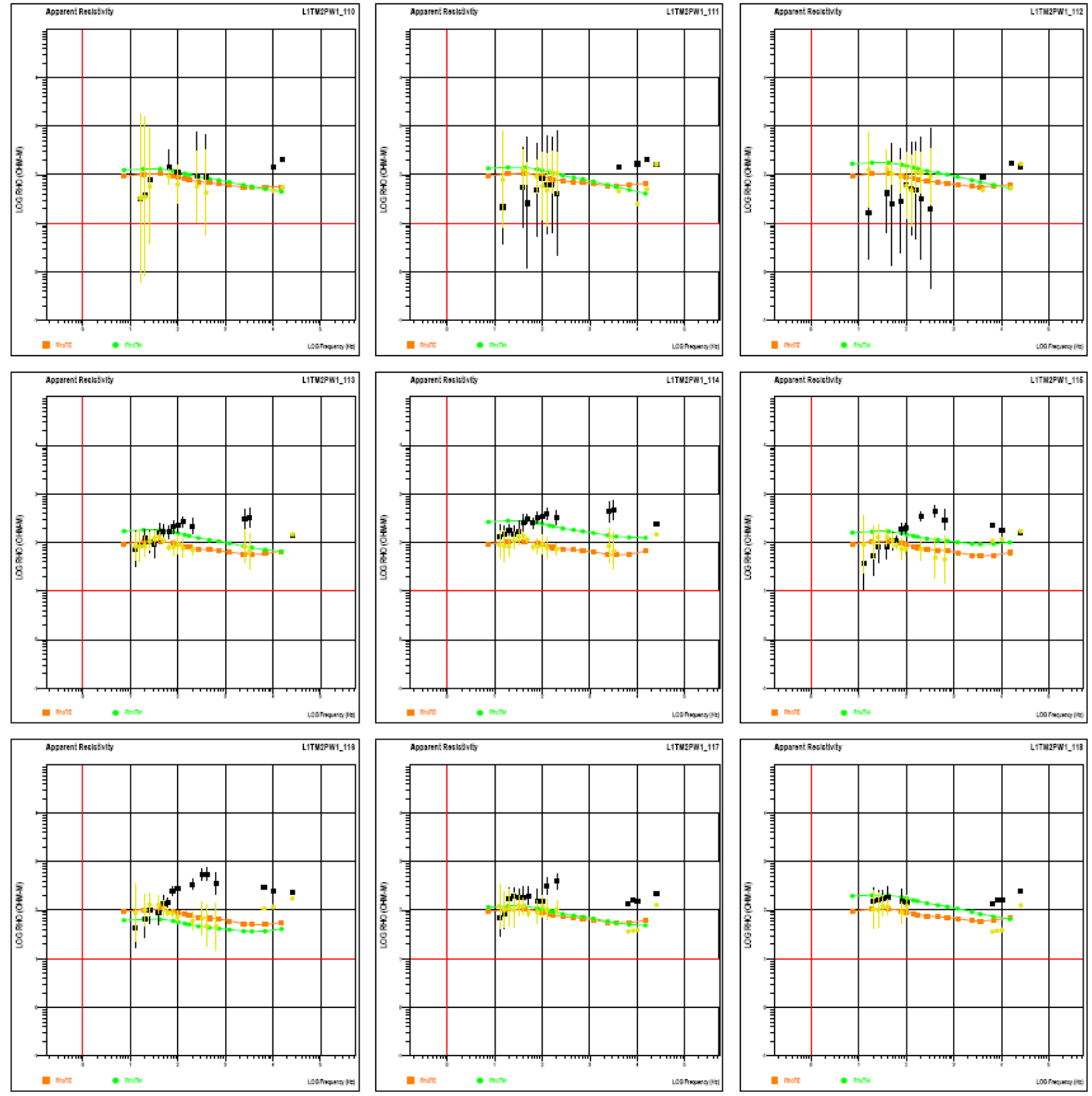

Figure B-44. Apparent resistivity data for 2006 Line 1, sites 10 to 18 . 


\title{
U.S. Geological Survey
}

\author{
Denver Federal Center \\ Denver, Colorado 80225 \\ MT Data for: L1 \\ Date: 09/18/08
}

F⿻

by

Geotools Corporation

5008 Balcones Dr. Suite 202

Austin, Texas 78731 USA

(512) 4540679
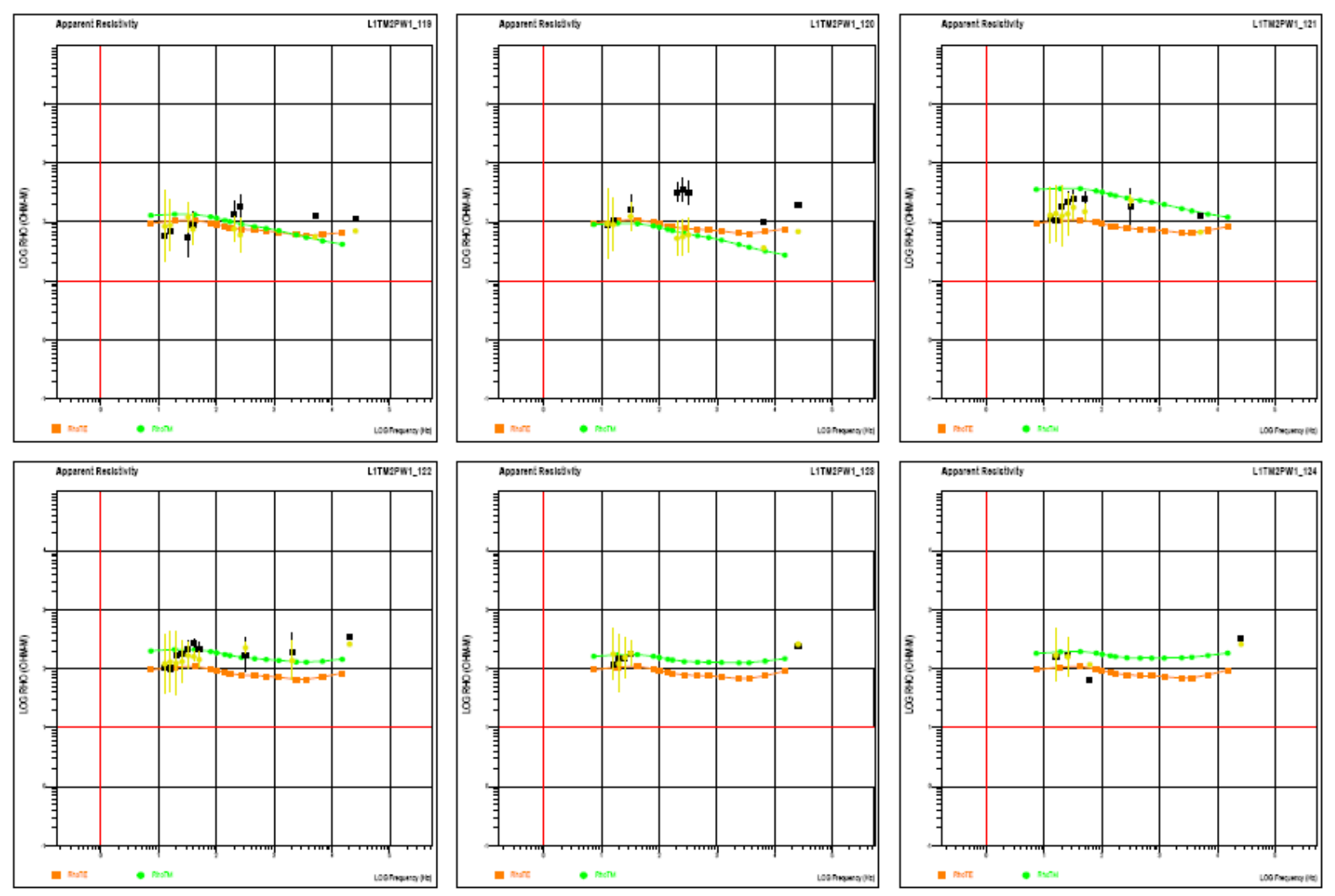

Figure B-45. Apparent resistivity data for 2006 Line 1, sites 19 to 24 . 


\title{
U.S. Geological Survey
}

\author{
Denver Federal Center \\ Denver, Colorado 80225 \\ MT Data for: L1 \\ Date: 09/18/08
}

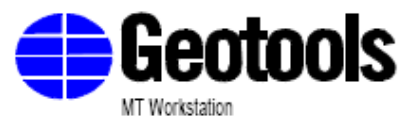

by

Gectools Corporation

5008 Belcones Dr. Suite 202

Austin, Texes 78731 USA

(512) 4540679
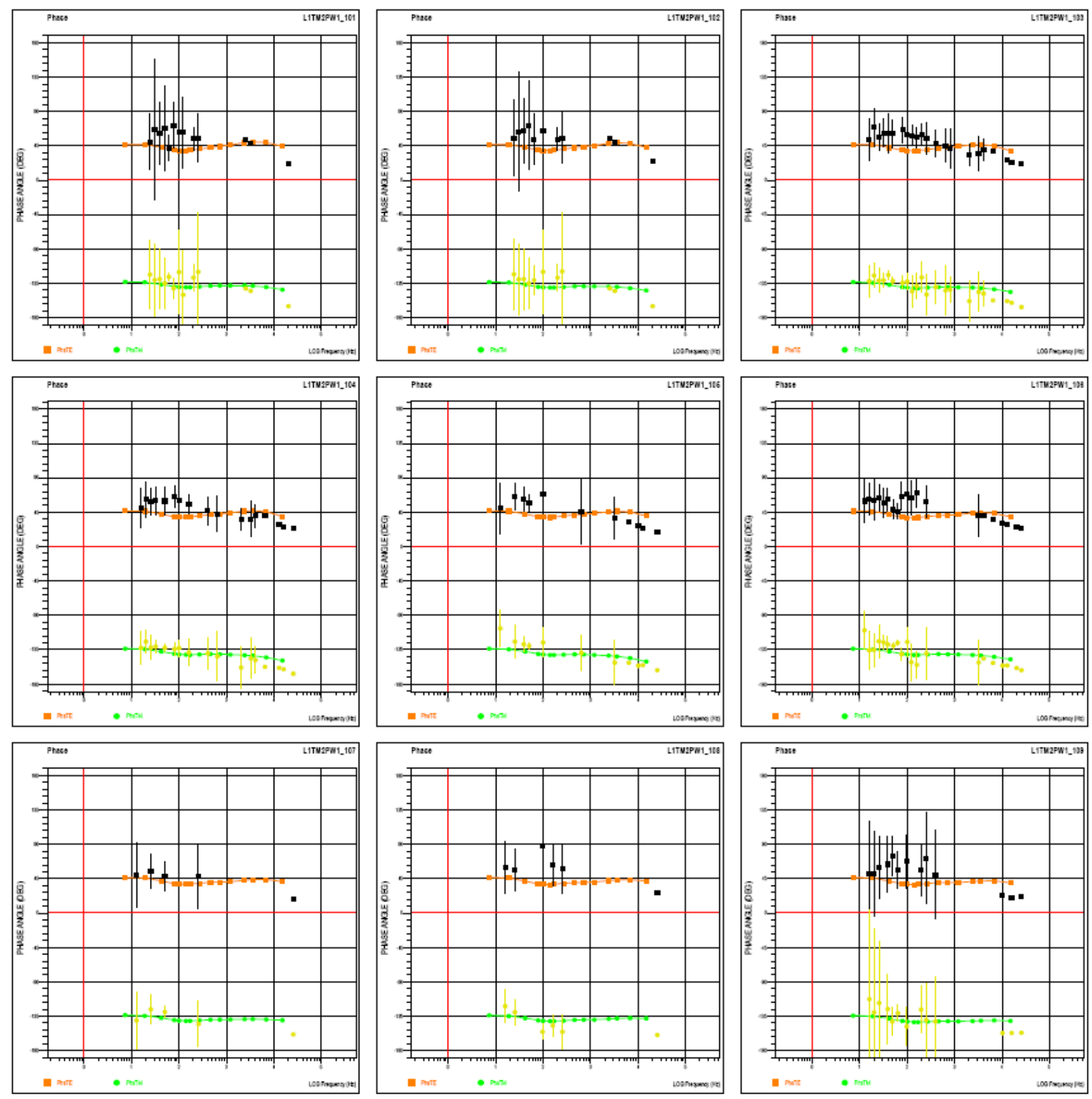

Figure B-46. Impedance phase data for 2006 Line 1, sites 1 to 9. 


\title{
U.S. Geological Survey
}

\author{
Denver Federal Center \\ Denver, Colorado 80225 \\ MT Data for: L1 \\ Date: 09/18/08
}

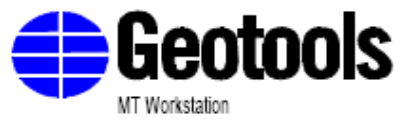

by

Geobols Corporetion

5008 Balcones Dr. Sulte 202

Austin, Texas 78731 USA

(512) 4540679
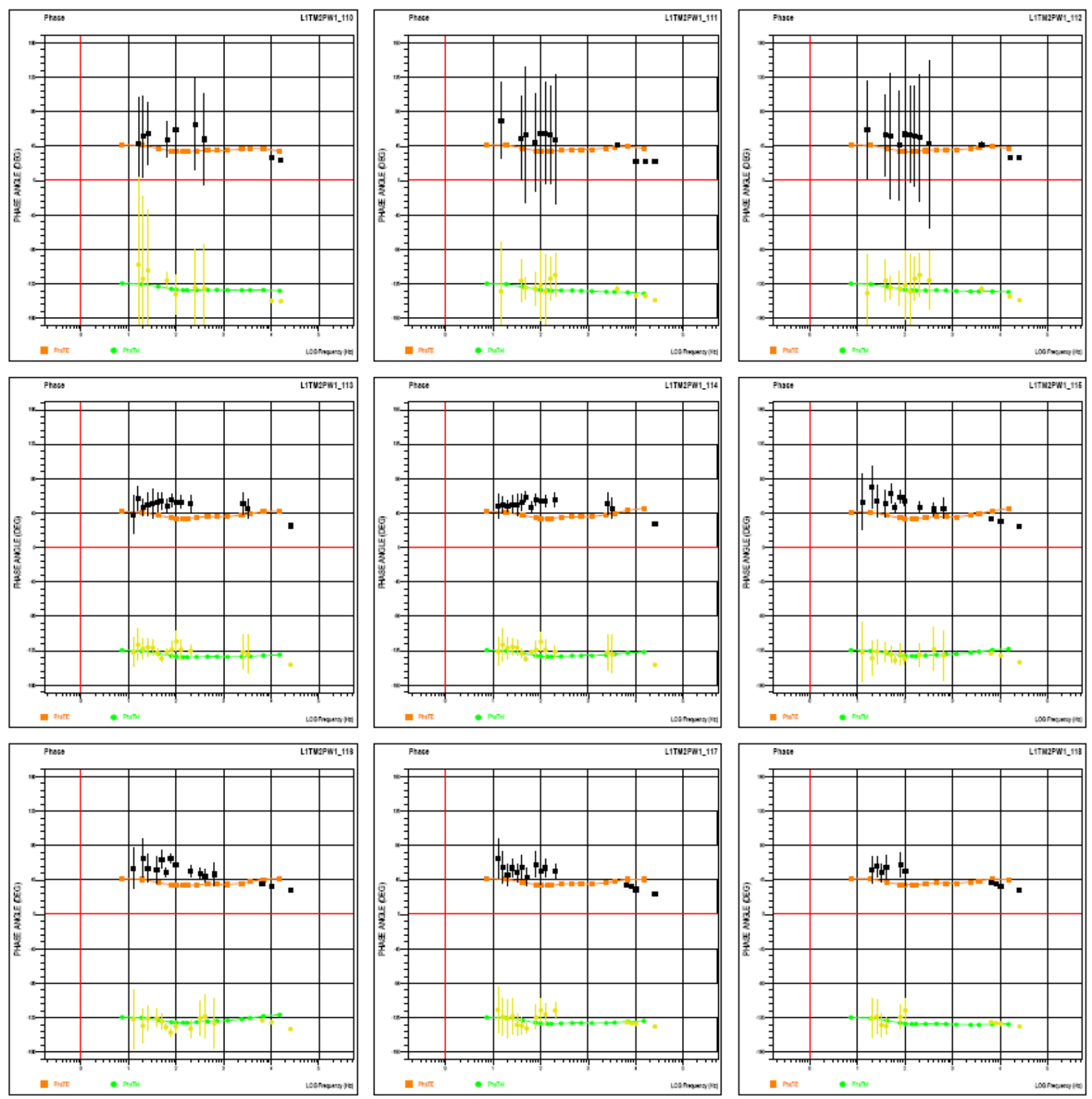

Figure B-47. Impedance phase data for 2006 Line 1, sites 10 to 18. 


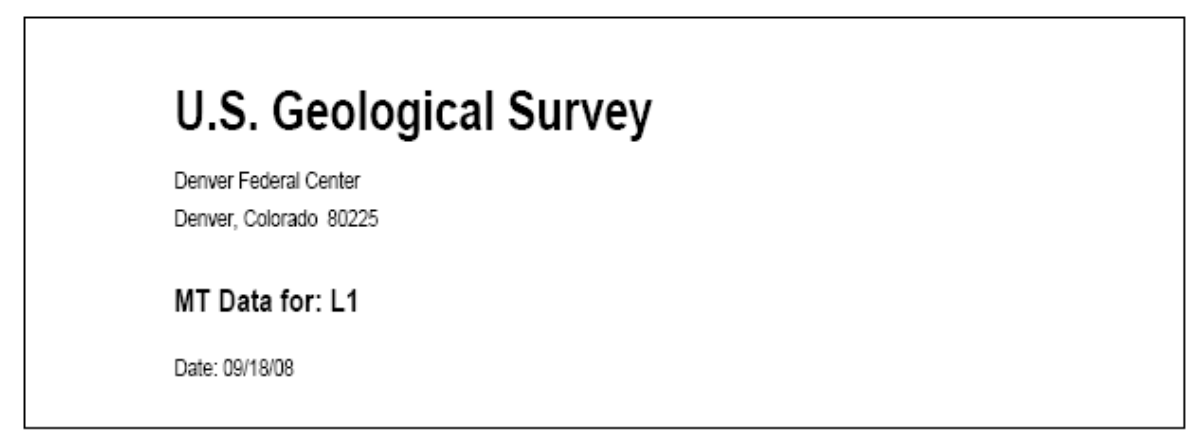

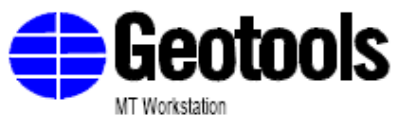

by

Geobols Corporation

5008 Balcones Dr. Suite 202

Austin, Texas 78731 USA

(512) 4540679
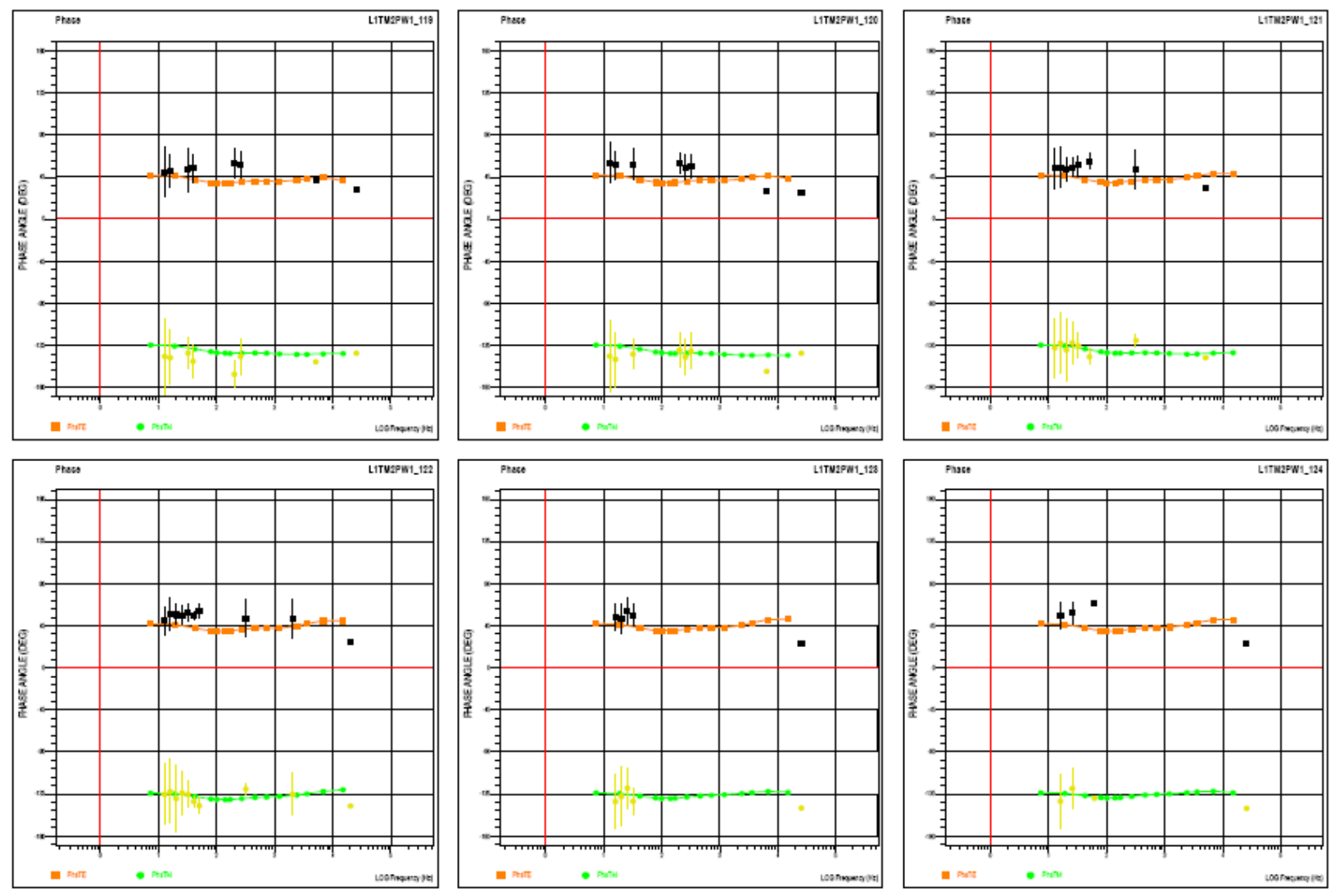

Figure B-48. Impedance phase data for 2006 Line 1, sites 19 to 24. 


\section{U.S. Geological Survey}

Denver Federal Center

Denver, Colorado 80225

MT Data for: L1

Date: 09/18/08
拝Geotools

by

Geotools Corporation

5808 Balcones Dr. Suite 202

Austin, Texas 78731 USA

(512) 454-0679
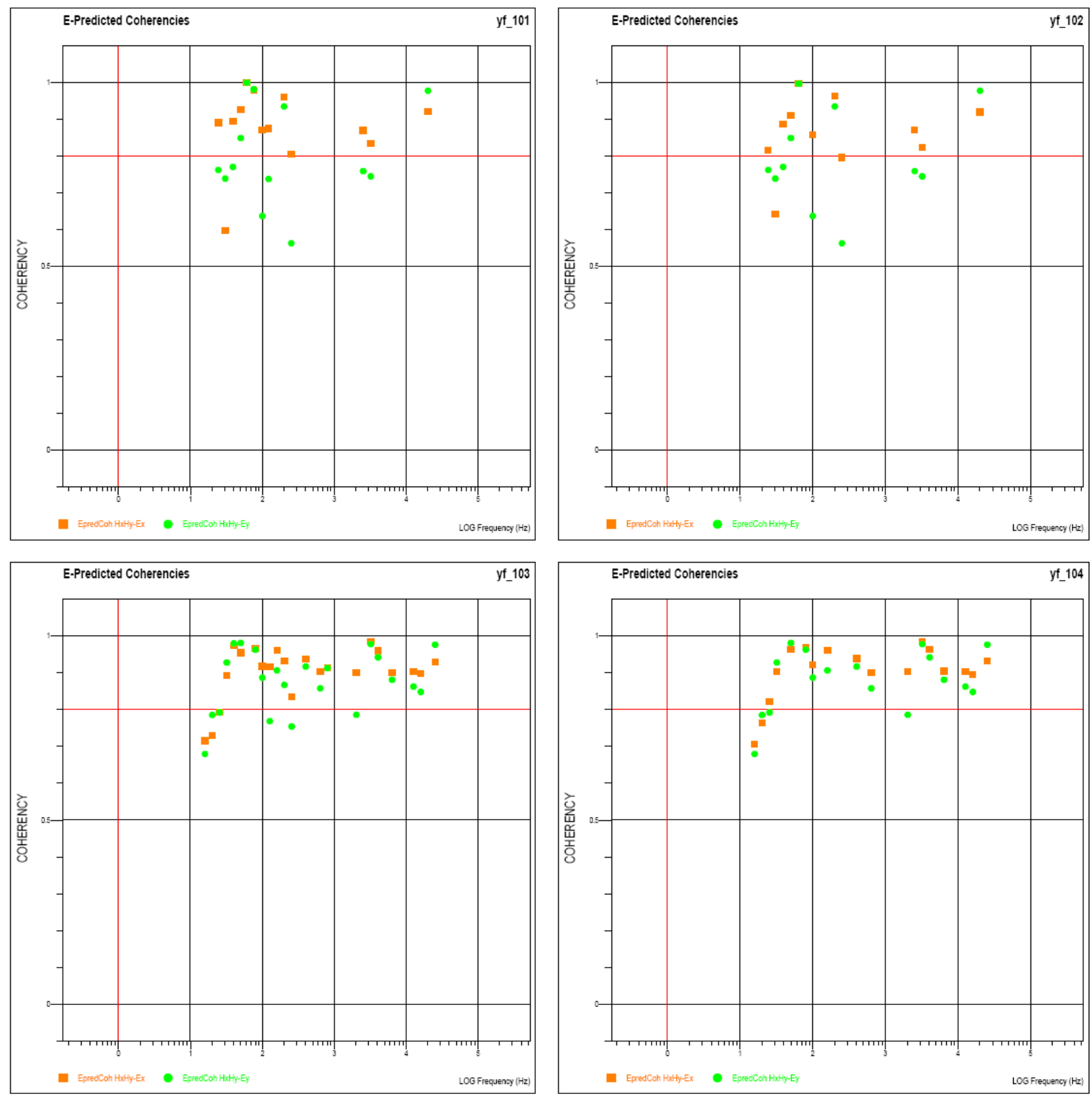

Figure B-49. Coherency data for 2006 Line 1, sites 1 to 4. 


\section{U.S. Geological Survey}

Denver Federal Center

Denver, Colorado 80225

MT Data for: L1

Date: 09/18/08

拝Geotools

MT Workstation

by

Geotools Corporation

5808 Balcones Dr. Suite 202

Austin, Texas 78731 USA

(512) 454-0679
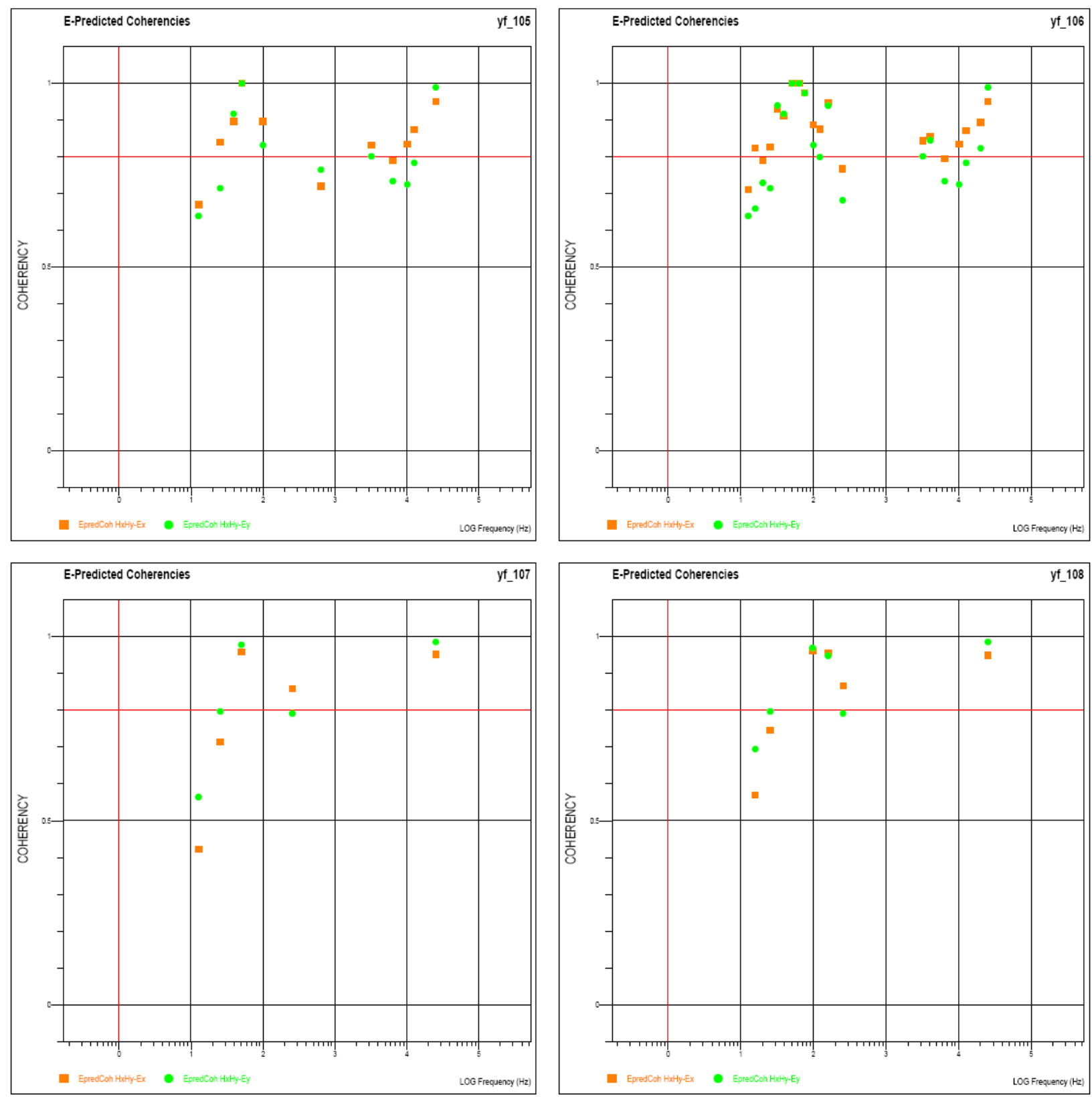

Figure B-50. Coherency data for 2006 Line 1, sites 5 to 8. 

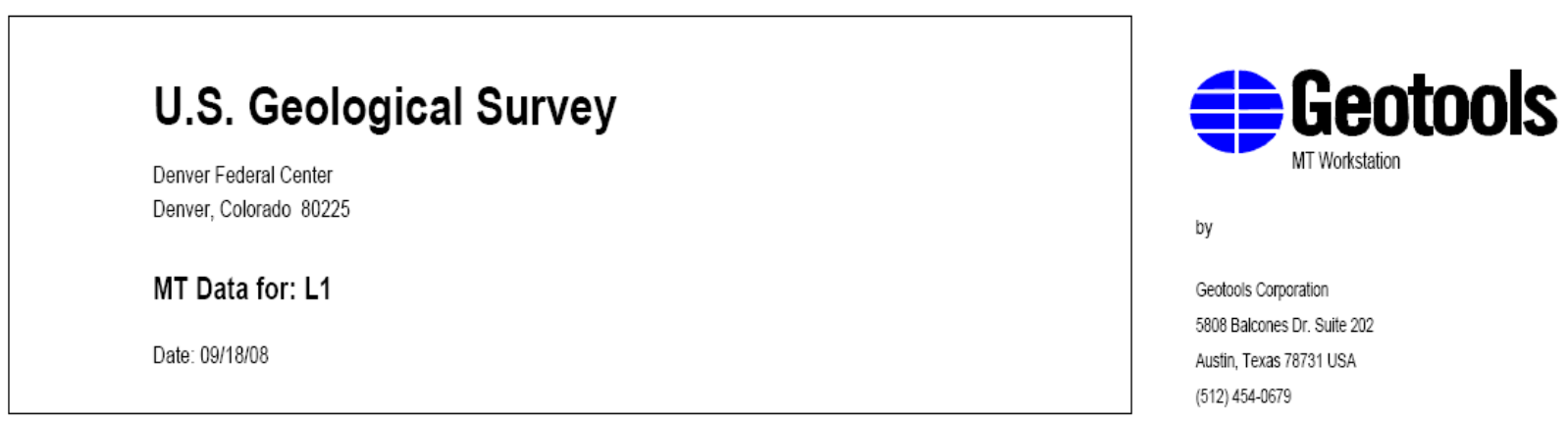

by

Geotools Corporation

5808 Balcones Dr. Suite 202

Austin, Texas 78731 USA

(512) 454-0679
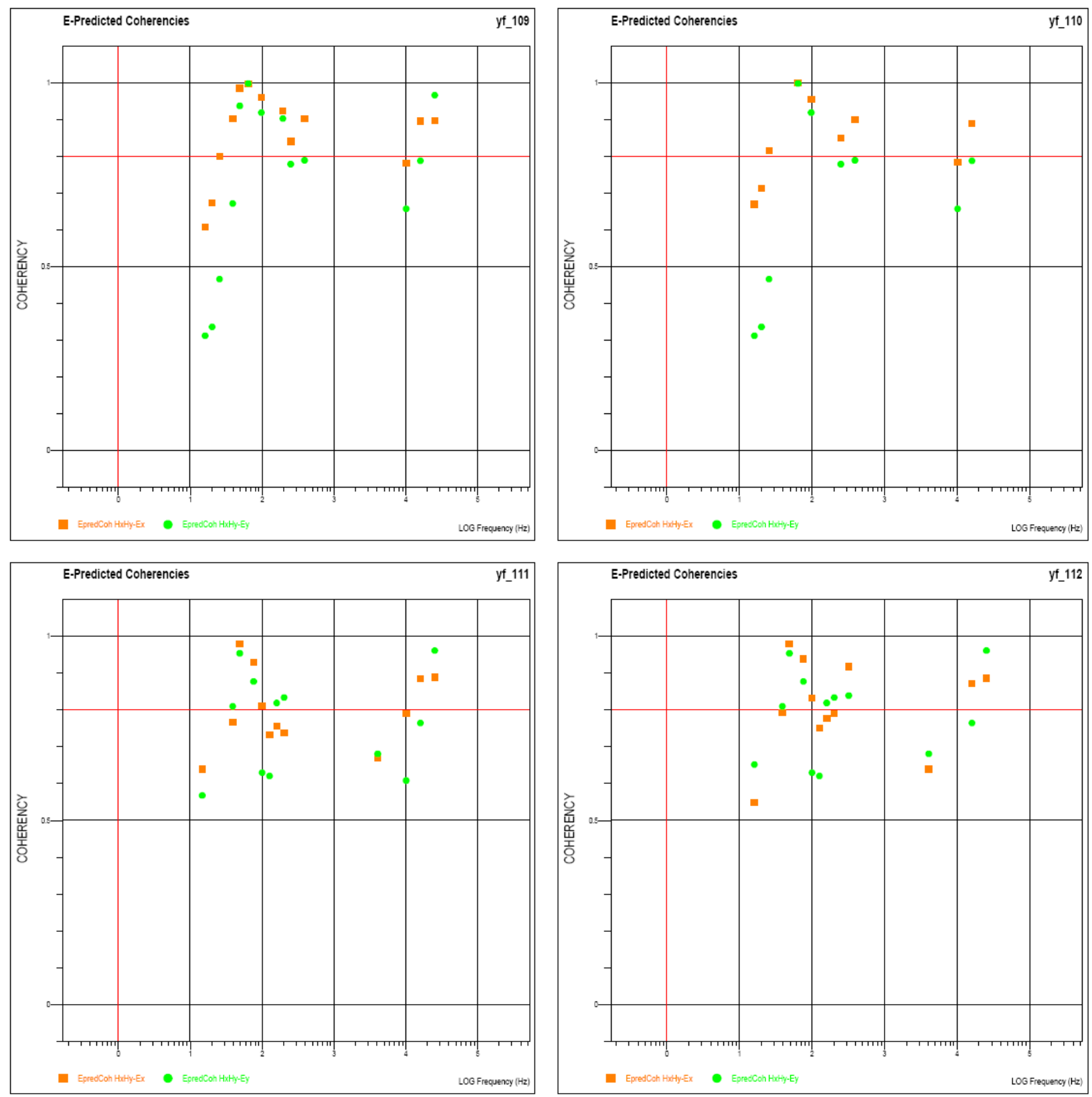

Figure B-51. Coherency data for 2006 Line 1, sites 9 to 12. 


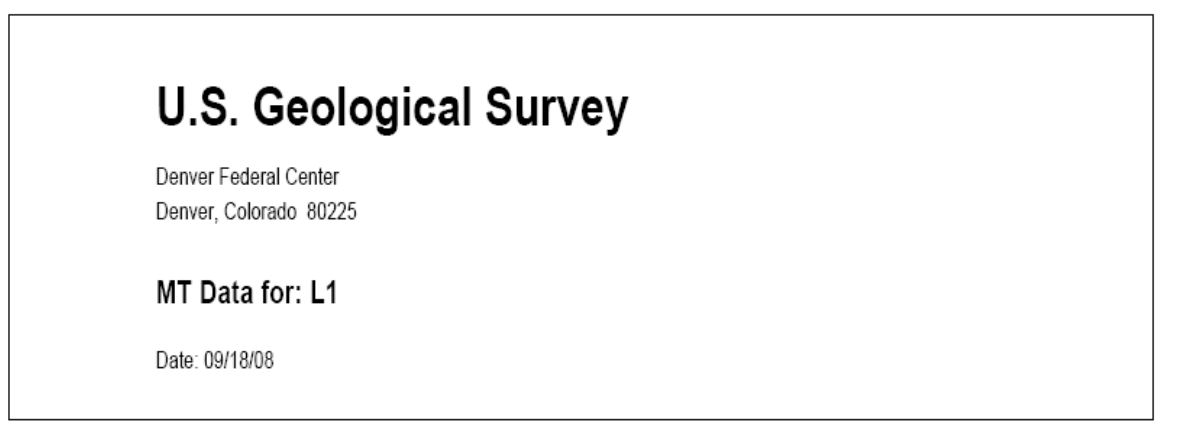

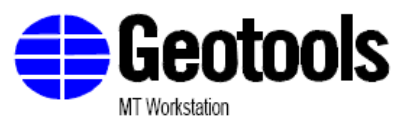

by

Geotools Corporation

5808 Balcones Dr. Suite 202

Austin, Texas 78731 USA

(512) $454-0679$
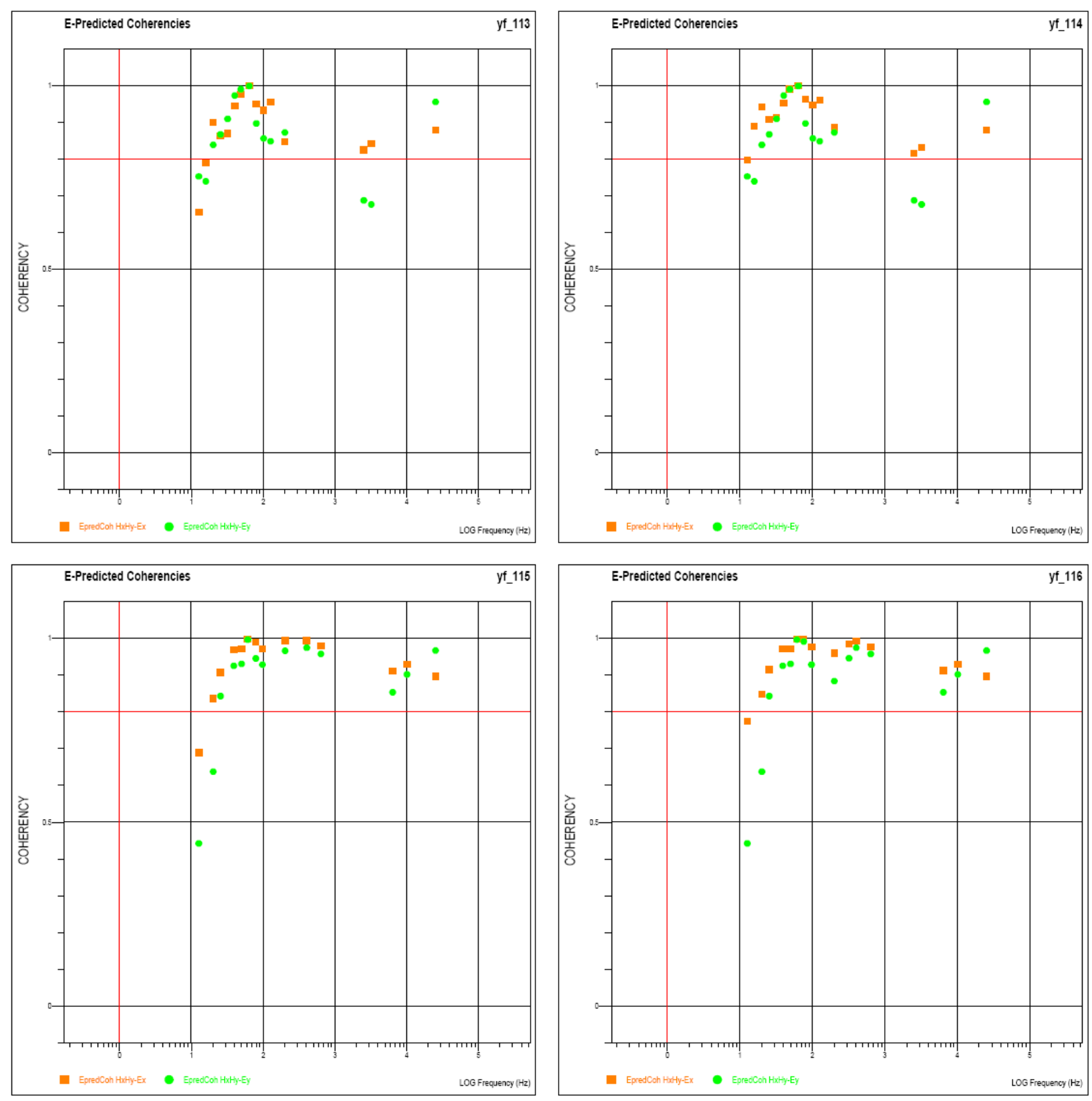

Figure B-52. Coherency data for 2006 Line 1, sites 13 to 16. 


\section{U.S. Geological Survey}

Denver Federal Center

Denver, Colorado 80225

MT Data for: L1

Date: 09/19/08

拝Geotools

MT Workstation

by

Geotools Corporation

5808 Balcones Dr. Suite 202

Austin, Texas 78731 USA

(512) 454-0679
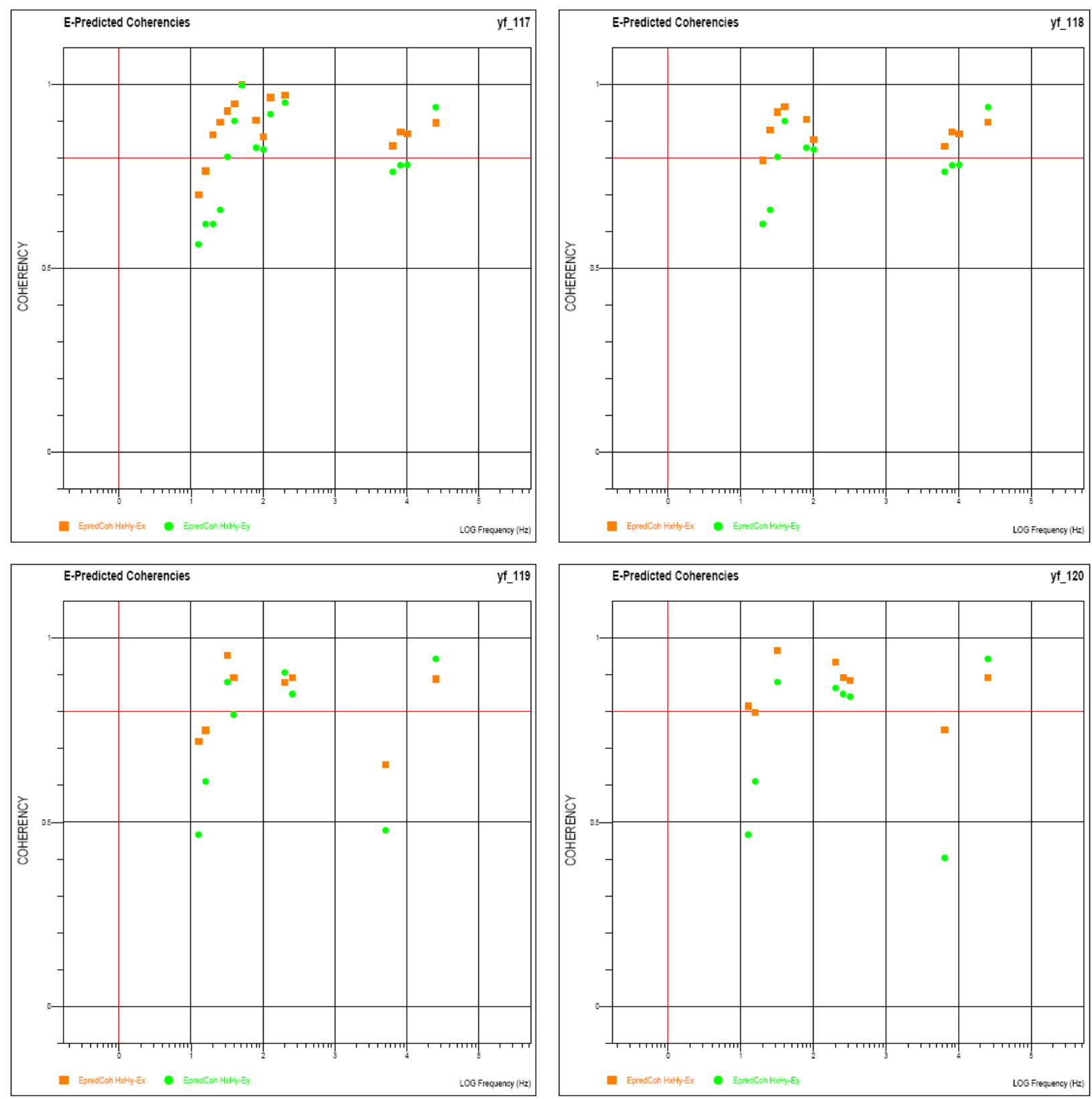

Figure B-53. Coherency data for 2006 Line 1, sites 17 to 20. 


\section{U.S. Geological Survey}

Denver Federal Center

Denver, Colorado 80225

MT Data for: L1

Date: 09/18/08
业Geotools

by

Geotools Corporation

5808 Balcones Dr. Suite 202

Austin, Texas 78731 USA

(512) 454-0679
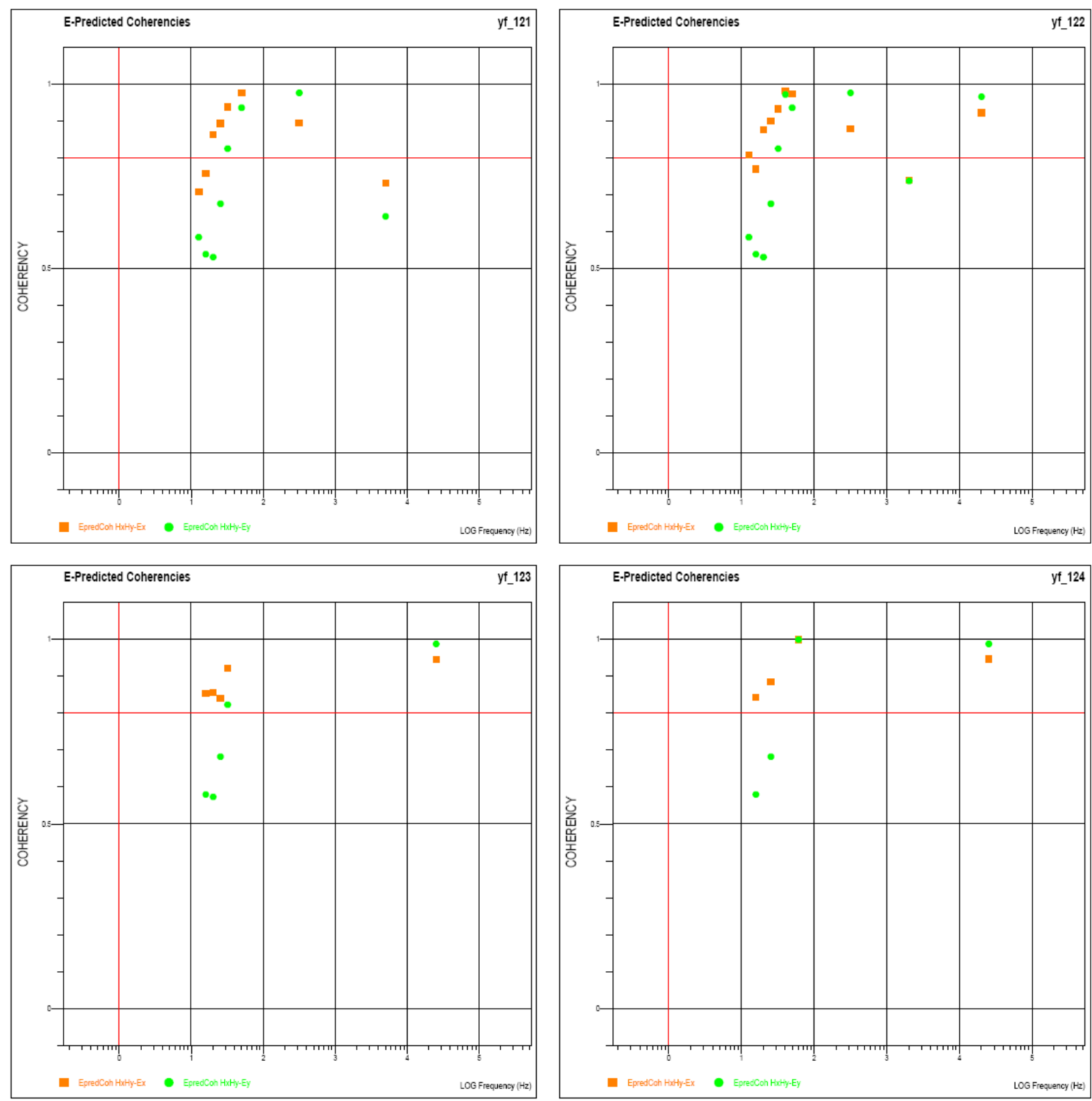

Figure B-54. Coherency data for 2006 Line 1, sites 21 to 24. 


\section{U.S. Geological Survey}

Denver Federal Center

Denver, Colorado 80225

MT Data for: L1

Date: 09/18/08
車Geotools

MT Workstation

by

Geotools Corporation

5808 Balcones Dr. Sute 202

Austin, Texas 78731 USA

(512) $454-0679$
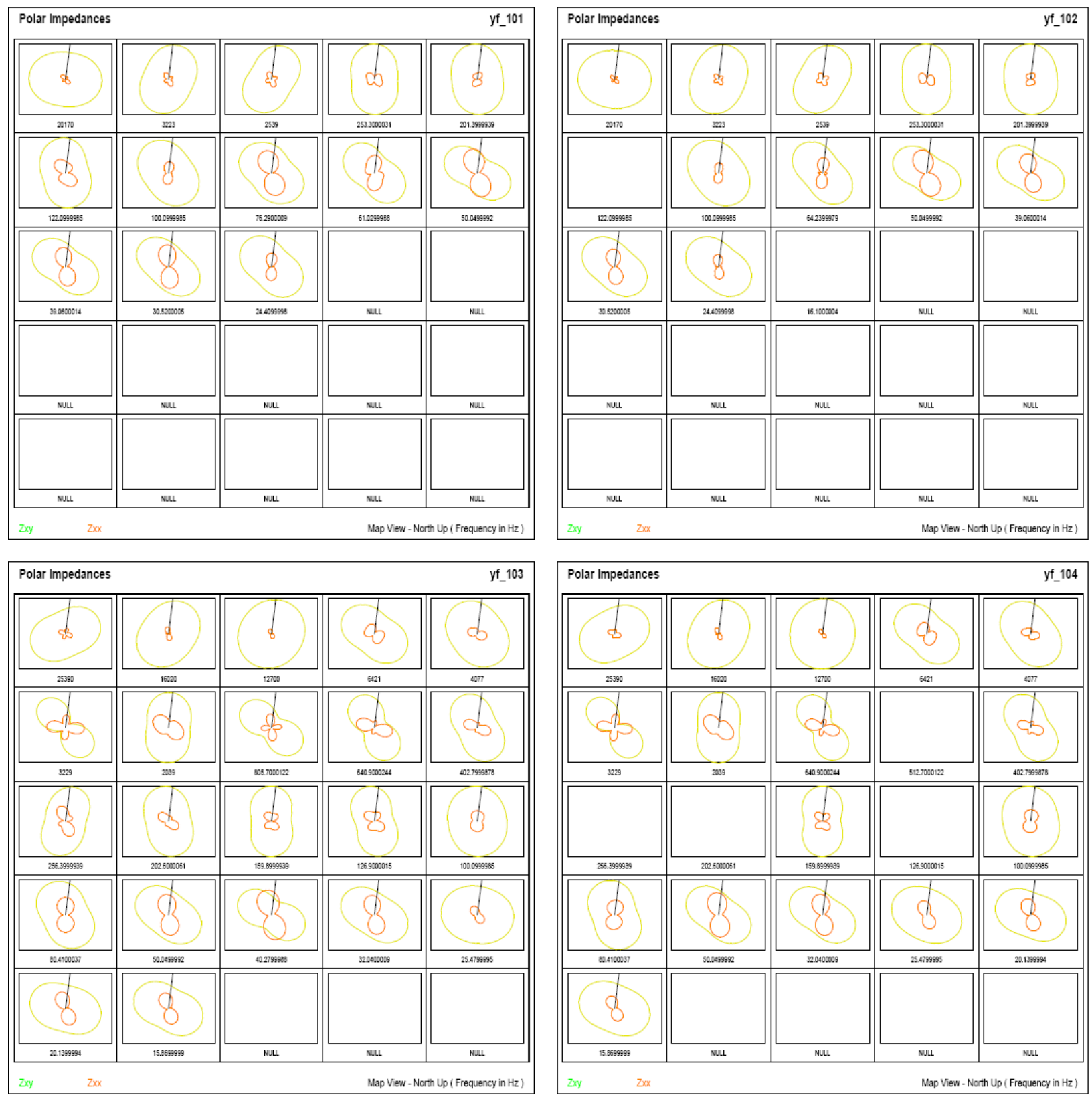

Figure B-55. Polar impedance plots for 2006 Line 1, sites 1 to 4. 


\section{U.S. Geological Survey}

Denver Federal Center

Denver, Colorado 80225

MT Data for: L1

Date: 09/18/08
平Geotools

MT Workstation

by

Geotools Corporation

5808 Balcones Dr. Sute 202

Austin, Texas 78731 USA

(512) 454-0679
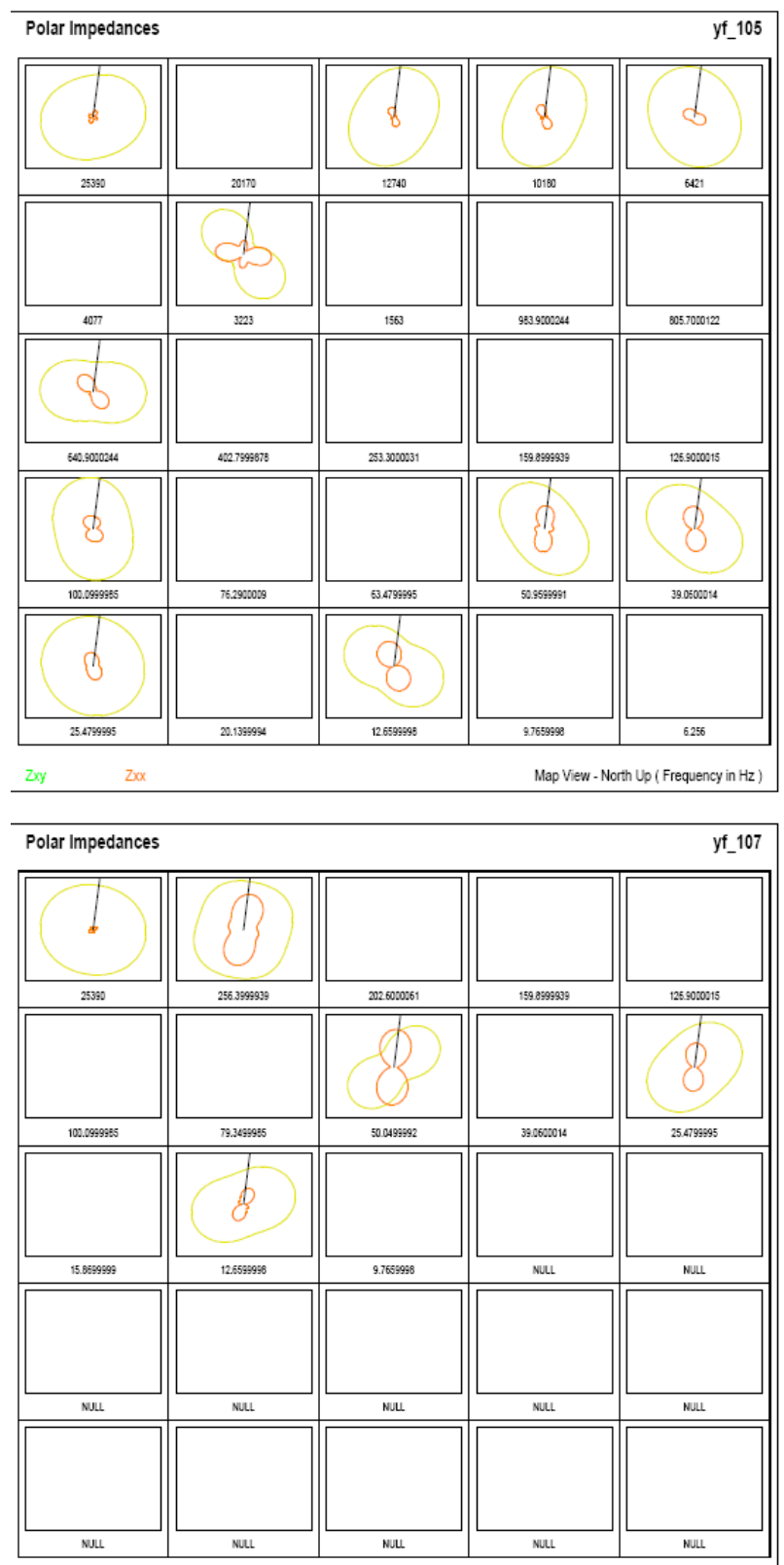

Zxy Zox

Map View - North Up (Frequency in Hz)
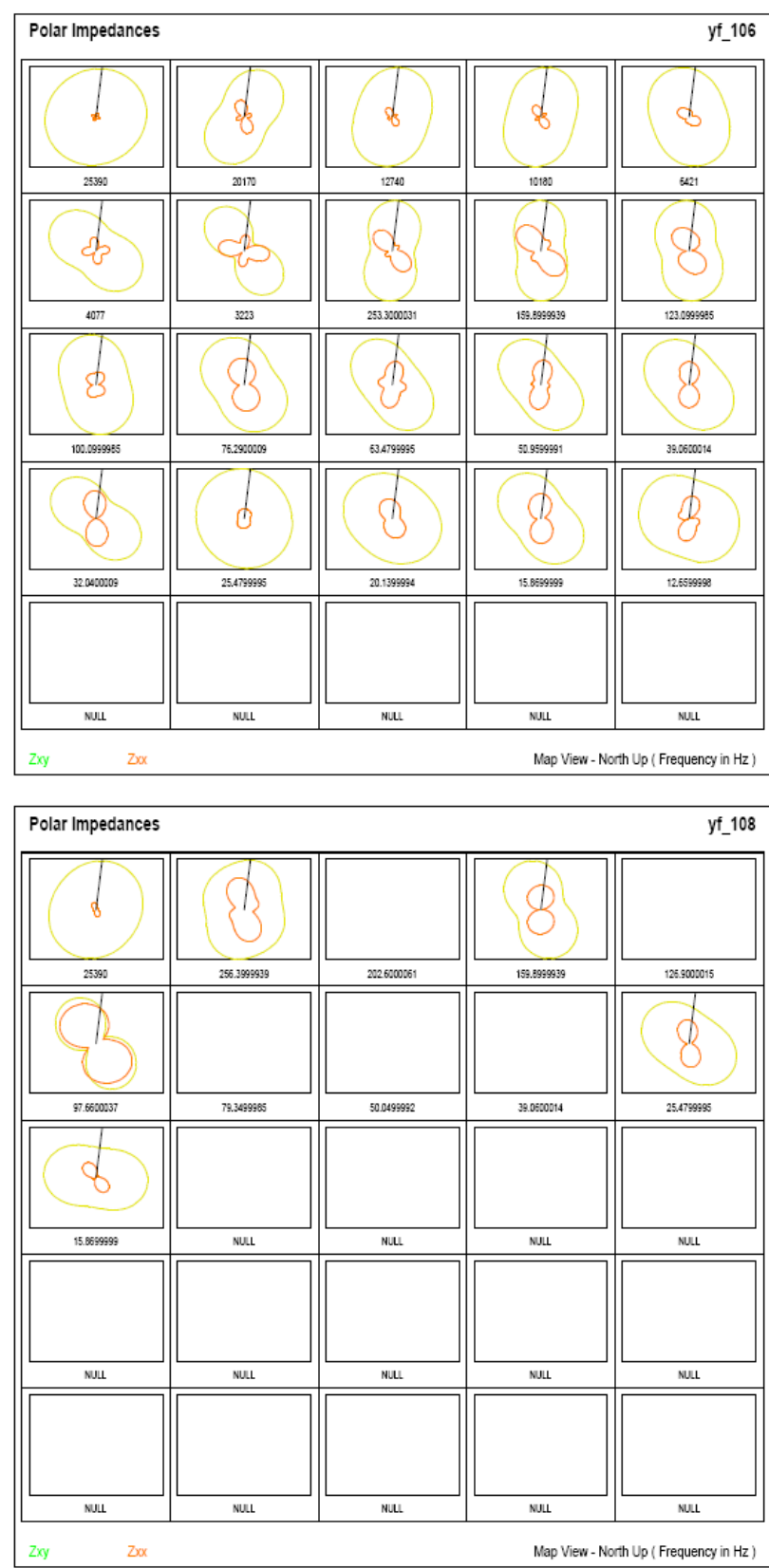

Figure B-56. Polar impedance plots for 2006 Line 1, sites 5 to 8 . 


\section{U.S. Geological Survey}

Denver Federal Center

Denver, Colorado 80225

MT Data for: L1

Date: 09/18/08
拝Geotools

MT Workstation

by

Geotools Corporation

5808 Balcones Dr. Sute 202

Austin, Texas 78731 USA

(512) 454-0679
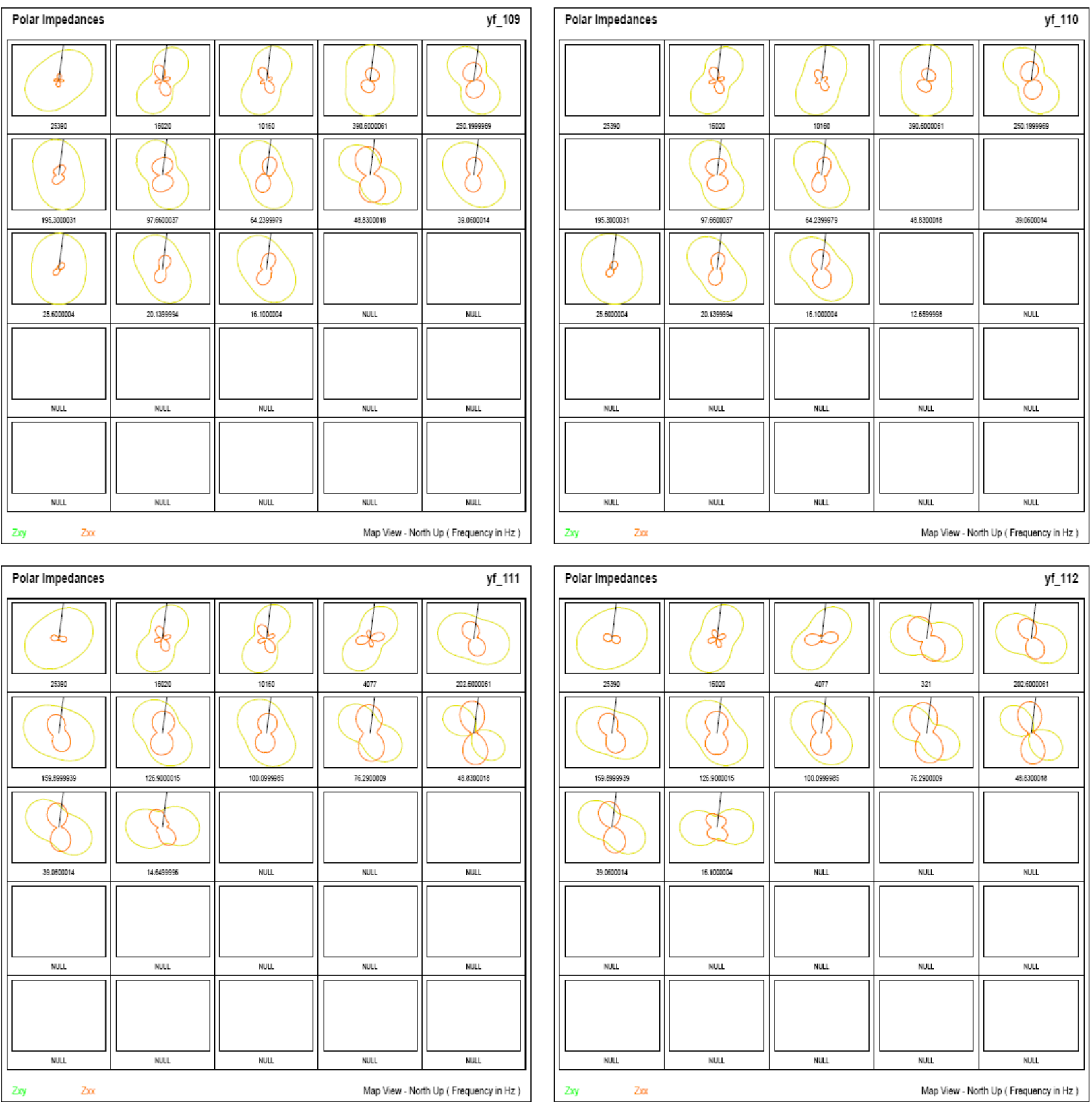

Figure B-57. Polar impedance plots for 2006 Line 1, sites 9 to 12. 


\section{U.S. Geological Survey}

Denver Federal Center

Denver, Colorado 80225

MT Data for: L1

Date: 09/18/08
平Geotools

MT Workstation

by

Geotools Corporation

5808 Balcones Dr. Sulte 202

Austin, Texas 78731 USA

(512) 454-0679
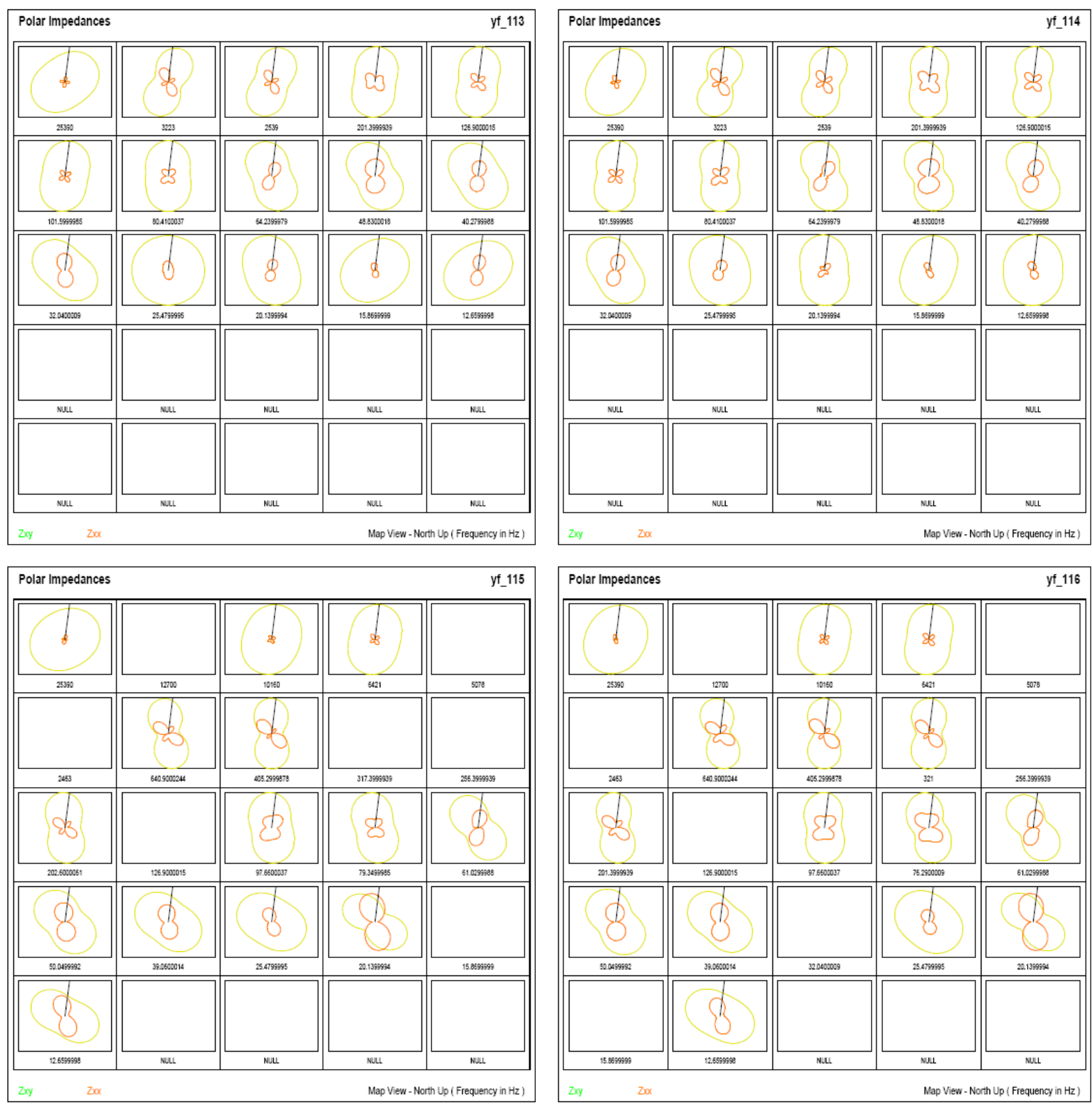

Figure B-58. Polar impedance plots for 2006 Line 1, sites 13 to 16. 


\section{U.S. Geological Survey}

\section{Denver Federal Center}

Denver, Colorado 80225

MT Data for: L1

Date: 09/18/08
贯Geotools

MT Workstation

by

Geotools Corporation

5808 Balcones Dr. Sute 202

Austin, Texas 78731 USA

(512) 454-0679
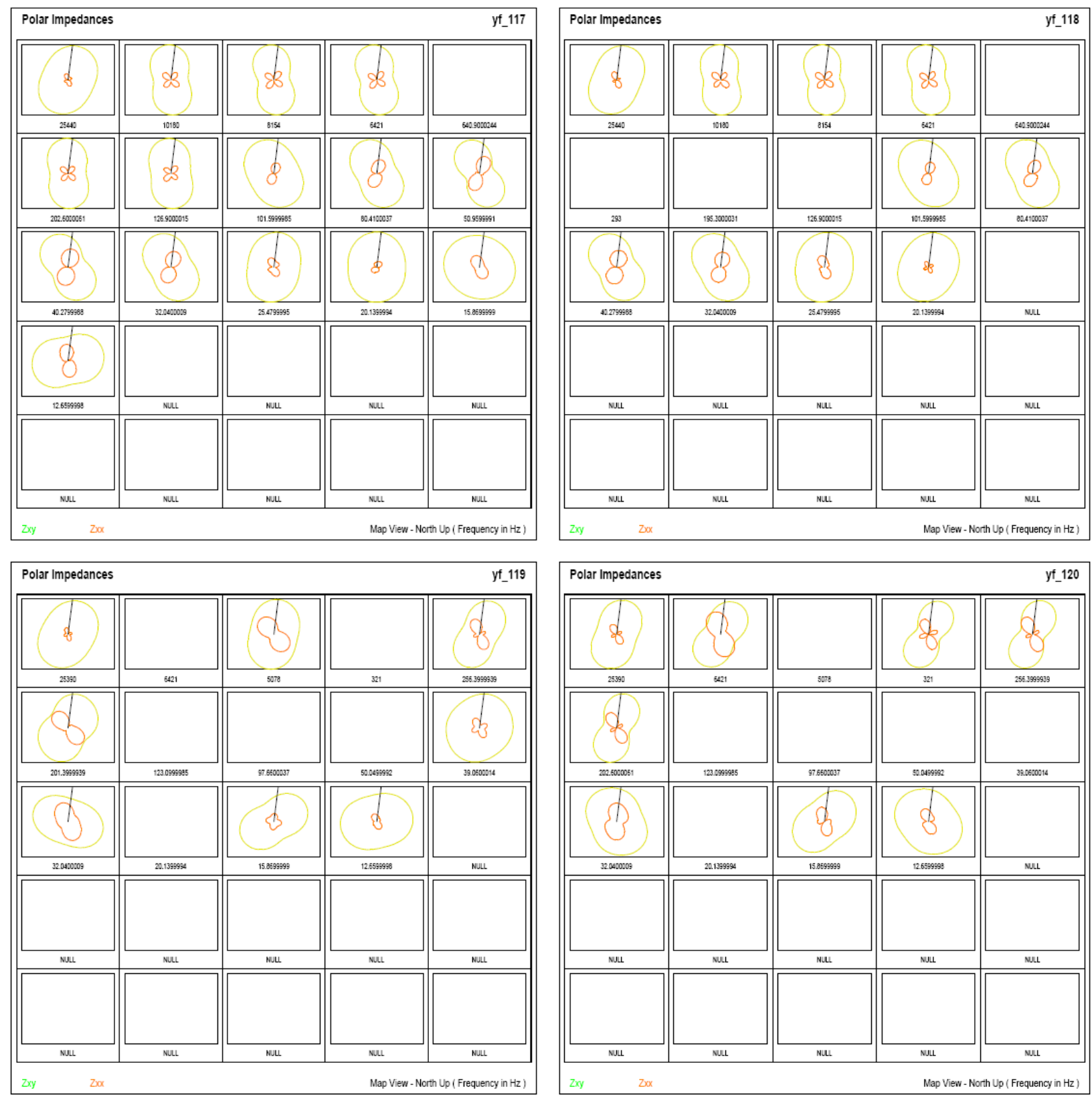

Figure B-59. Polar impedance plots for 2006 Line 1, sites 17 to 20. 


\section{U.S. Geological Survey}

Denver Federal Center

Denver, Colorado 80225

MT Data for: L1

Date: 09/18/08
拝Geotools

MT Workstation

by

Geotools Corporation

5808 Balcones Dr. Suite 202

Austin, Texas 78731 USA

(512) 454-0679
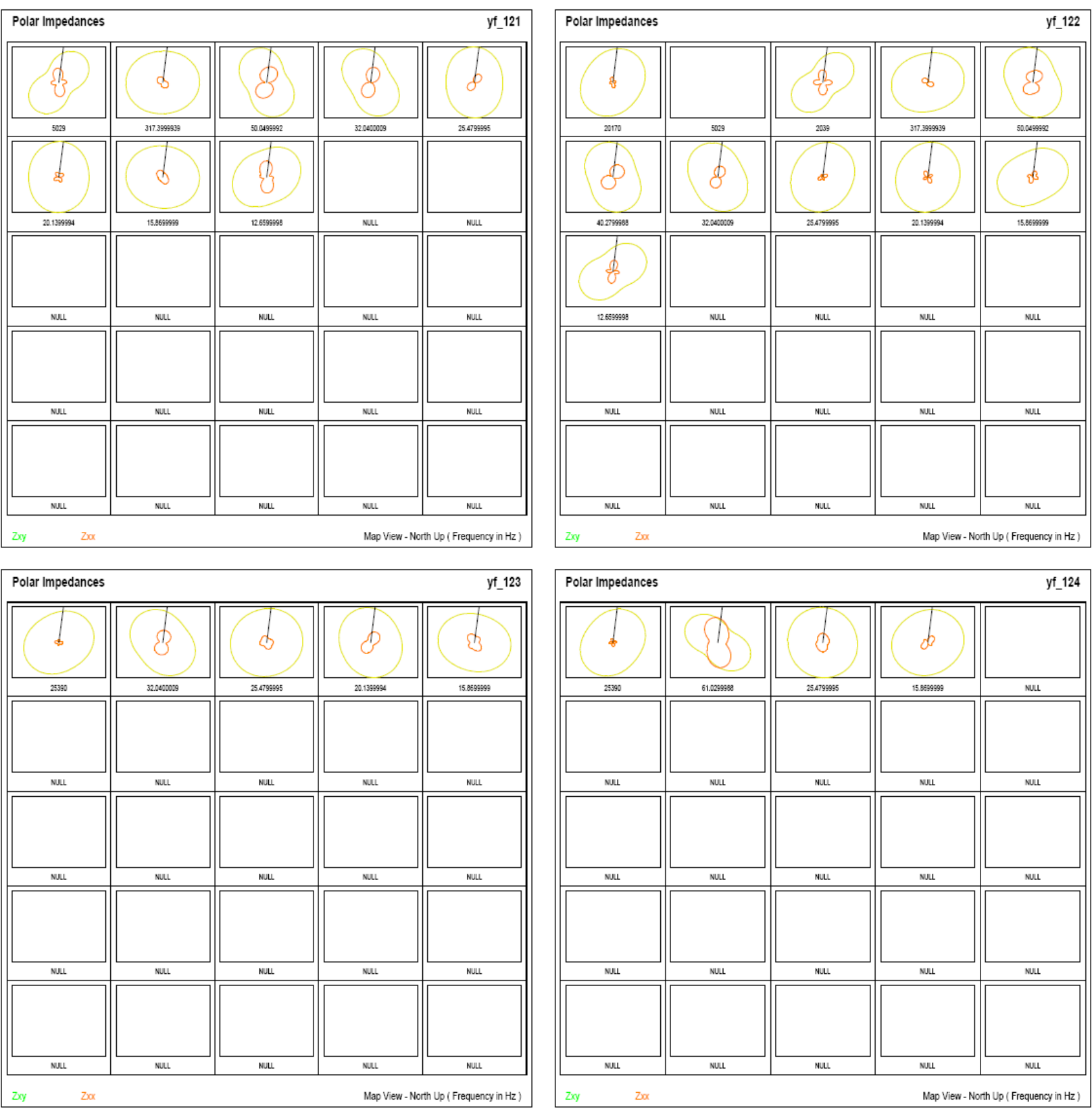

Figure B-60. Polar impedance plots for 2006 Line 1, sites 21 to 24. 


\section{U.S. Geological Survey}

Denver Federal Center

Denver, Colorado 80225

MT Data for: L1

Date: $09 / 18 / 08$
車Geotools

MT Workstation

by

Geotools Corporation

5808 Balcones Dr. Suite 202

Austin, Texas 78731 USA

(512) 454-0679
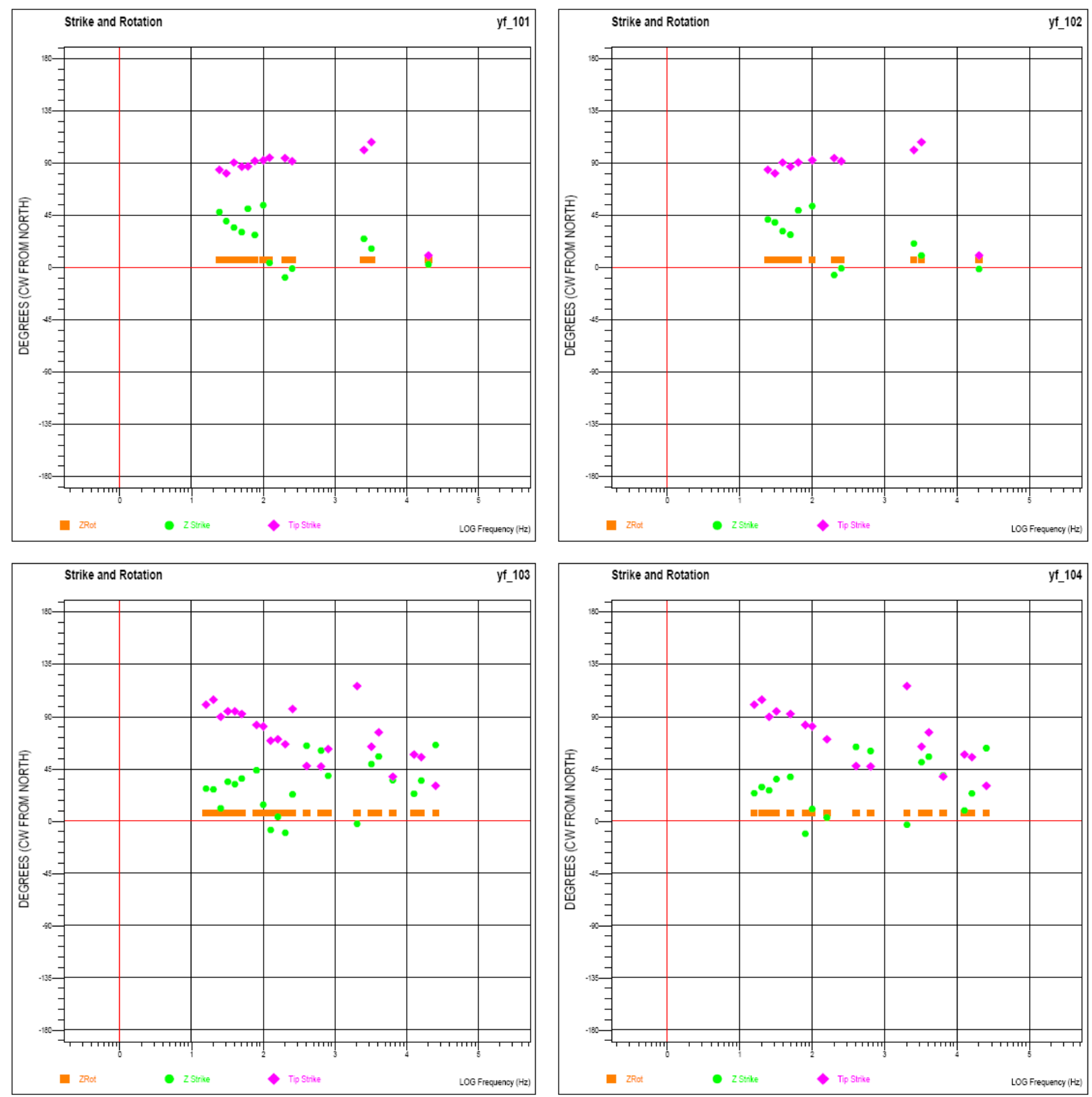

Figure B-61. Impedance strike, rotation, and tipper strike for 2006 Line 1, sites 1 to 4. 


\section{U.S. Geological Survey}

Denver Federal Center

Denver, Colorado 80225

MT Data for: L1

Date: 09/18/08
拝Geotools

MT Workstation

by

Geotools Corporation

5808 Balcones Dr. Sulte 202

Austin, Texas 78731 USA

(512) 454-0679
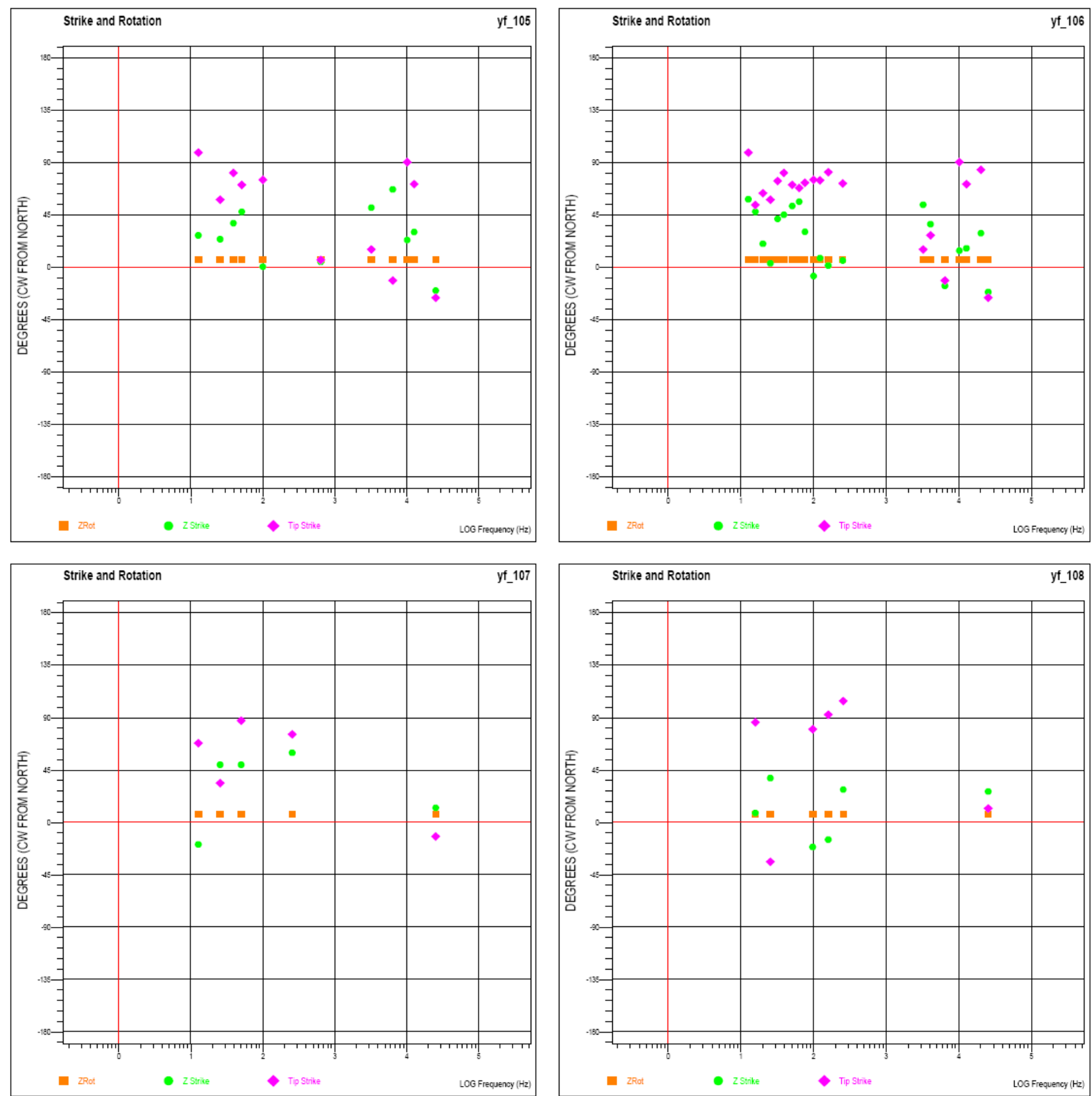

Figure B-62. Impedance strike, rotation, and tipper strike for 2006 Line 1, sites 5 to 8. 


\section{U.S. Geological Survey}

Denver Federal Center

Denver, Colorado 80225

MT Data for: L1

Date: $09 / 18 / 08$
Geotools

MT Workstation

by

Geotools Corporation

5808 Balcones Dr. Suite 202

Austin, Texas 78731 USA

(512) 454-0679
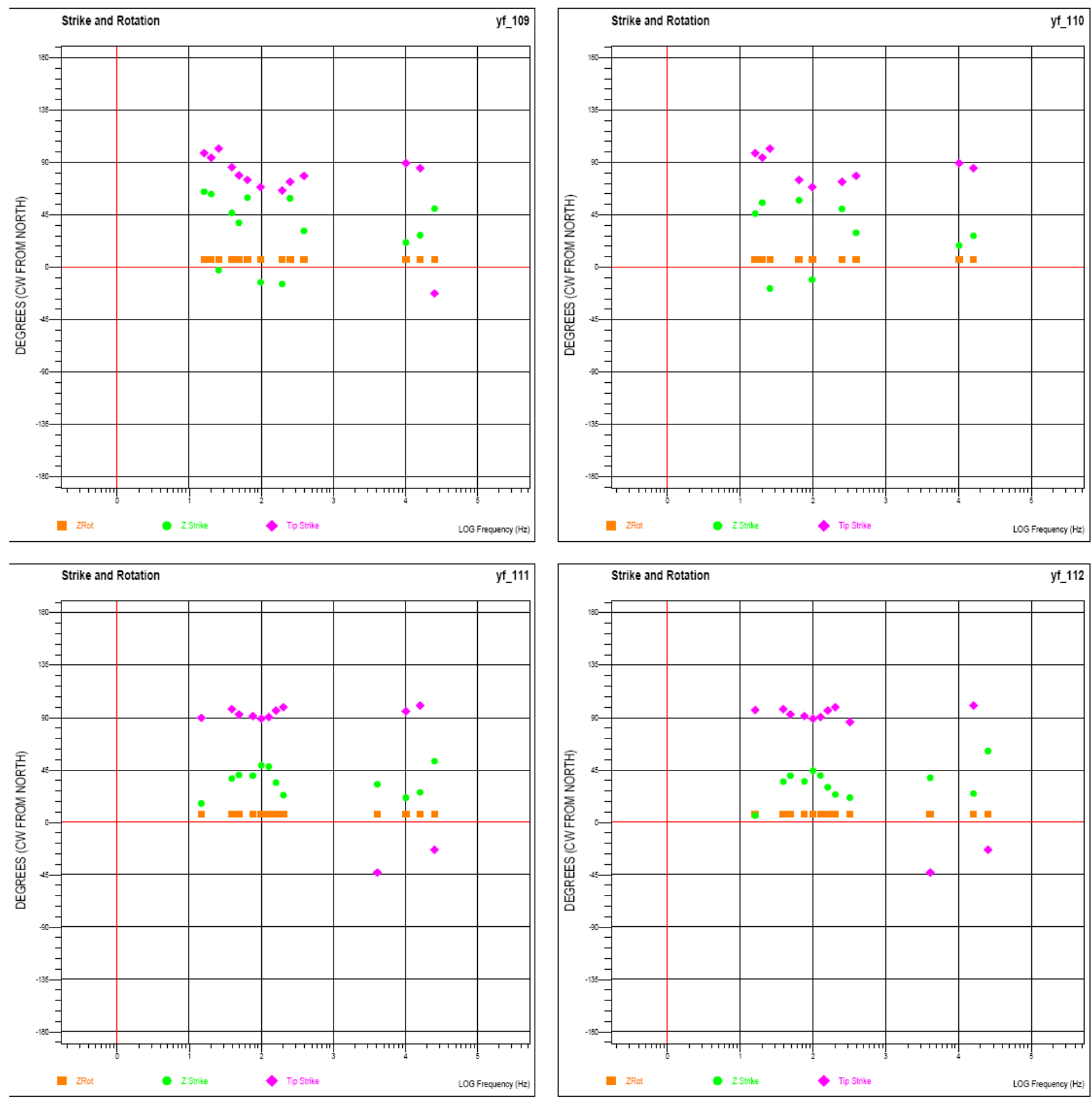

Figure B-63. Impedance strike, rotation, and tipper strike for 2006 Line 1, sites 9 to 12. 


\section{U.S. Geological Survey}

Denver Federal Center

Denver, Colorado 80225

MT Data for: L1

Date: $09 / 18 / 08$
冓Geotools

MT Workstation

by

Geotools Corporation

5808 Balcones Dr. Suite 202

Ausin, Texas 78731 USA

(512) 454-0679
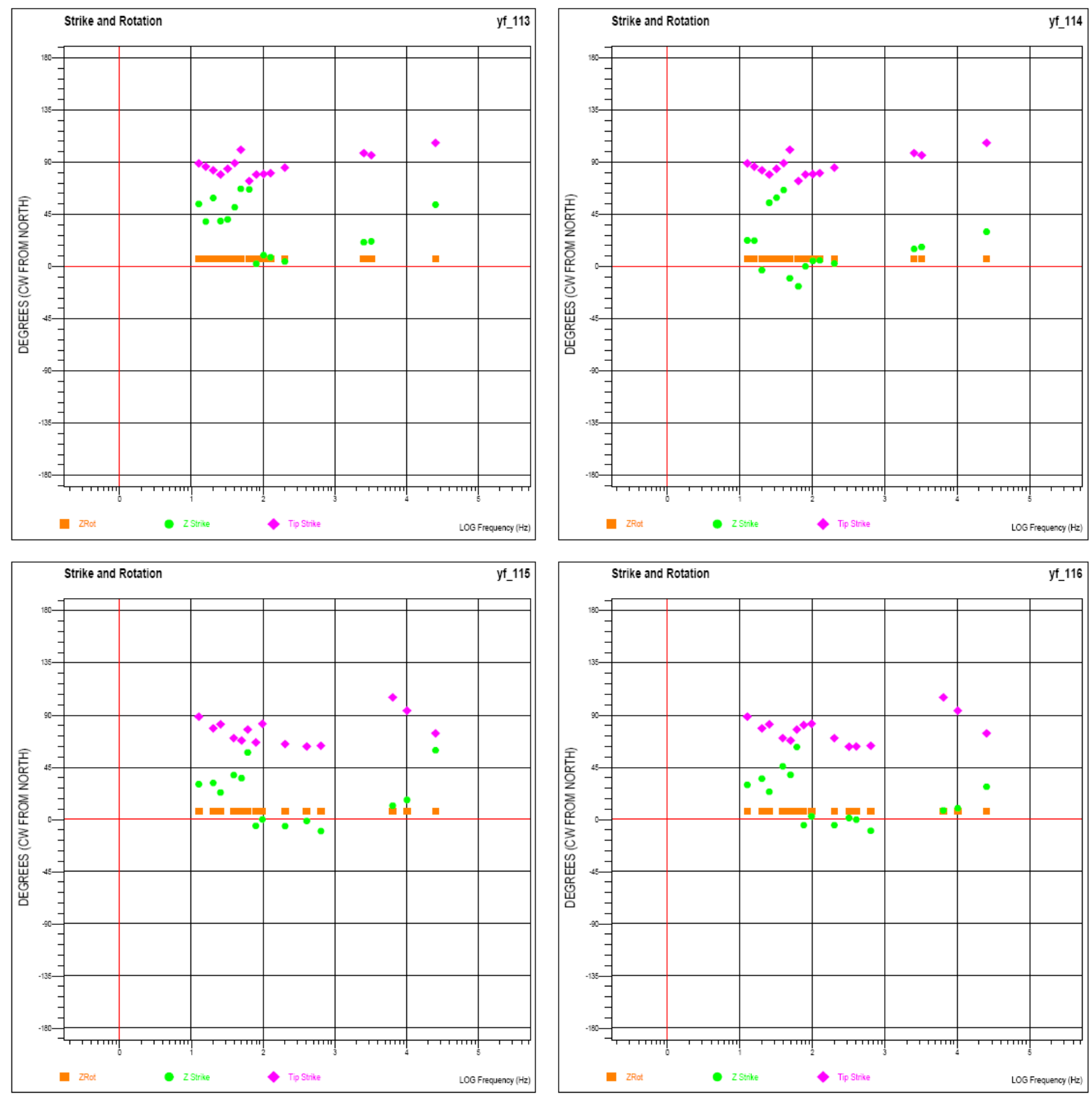

Figure B-64. Impedance strike, rotation, and tipper strike for 2006 Line 1, sites 13 to 16. 


\section{U.S. Geological Survey}

Denver Federal Center

Denver, Colorado 80225

MT Data for: L1

Date: 09/18/08
車Geotools

MT Workstation

by

Geotools Corporation

5808 Balcones Dr. Suite 202

Austin, Texas 78731 USA

(512) 454-0679
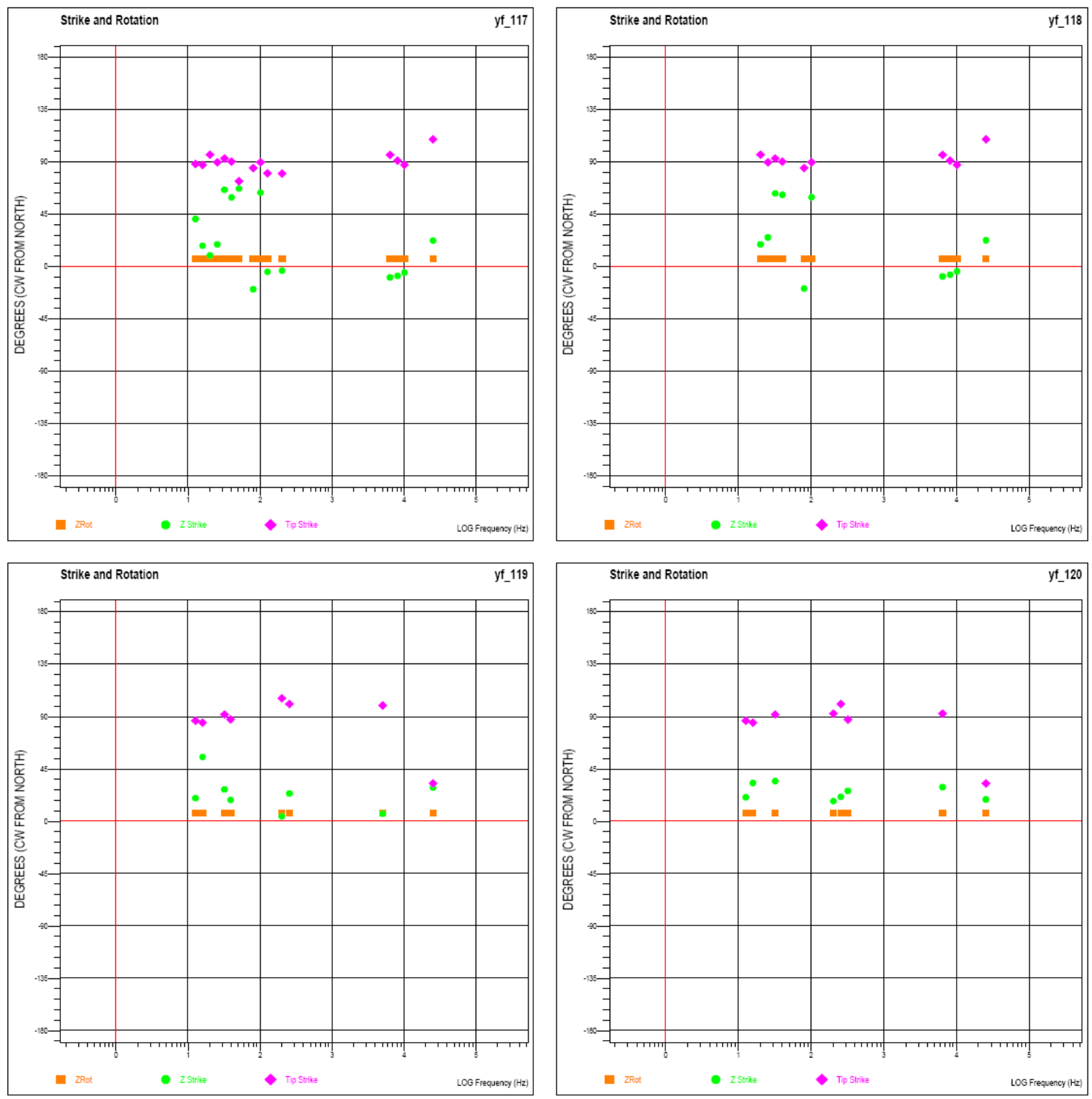

Figure B-65. Impedance strike, rotation, and tipper strike for 2006 Line 1, sites 17 to 20. 


\section{U.S. Geological Survey}

Denver Federal Center

Denver, Colorado 80225

MT Data for: L1

Date: $09 / 18 / 08$
冓Geotools

MT Workstation

by

Geotools Corporation

5808 Balcones Dr. Suite 202

Austin, Texas 78731 USA

(512) 454-0679
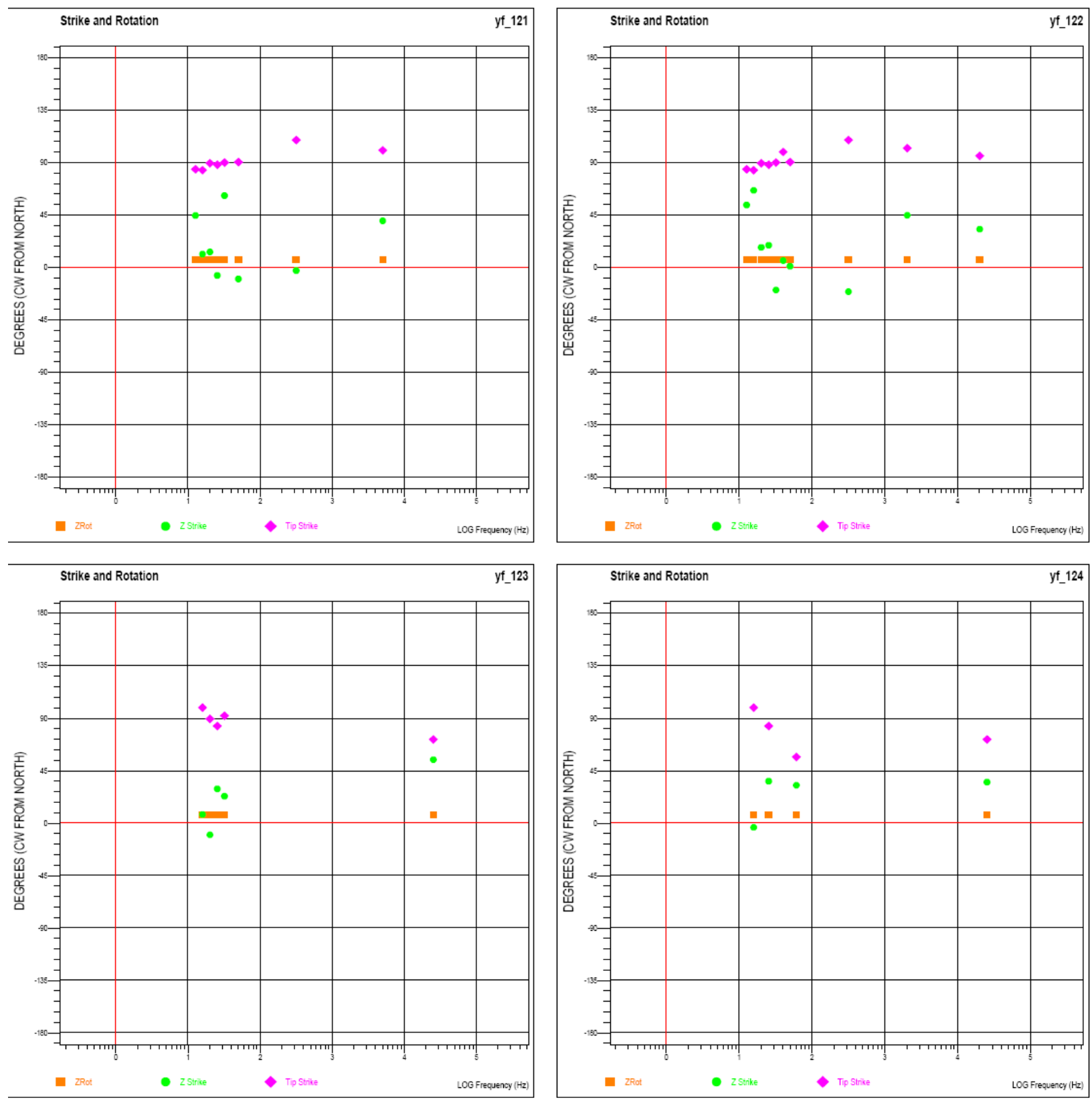

Figure B-66. Impedance strike, rotation, and tipper strike for 2006 Line 1, sites 21 to 24. 


\section{U.S. Geological Survey}

Denver Federal Center

Denver, Colorado 80225

MT Data for: L2

Date: $09 / 23 / 08$

\section{业Geotools}

MT Workstation

by

Geotools Corporation

5808 Balcones Dr. Sulte 202

Austin, Texas 78731 USA

(512) 454-0679

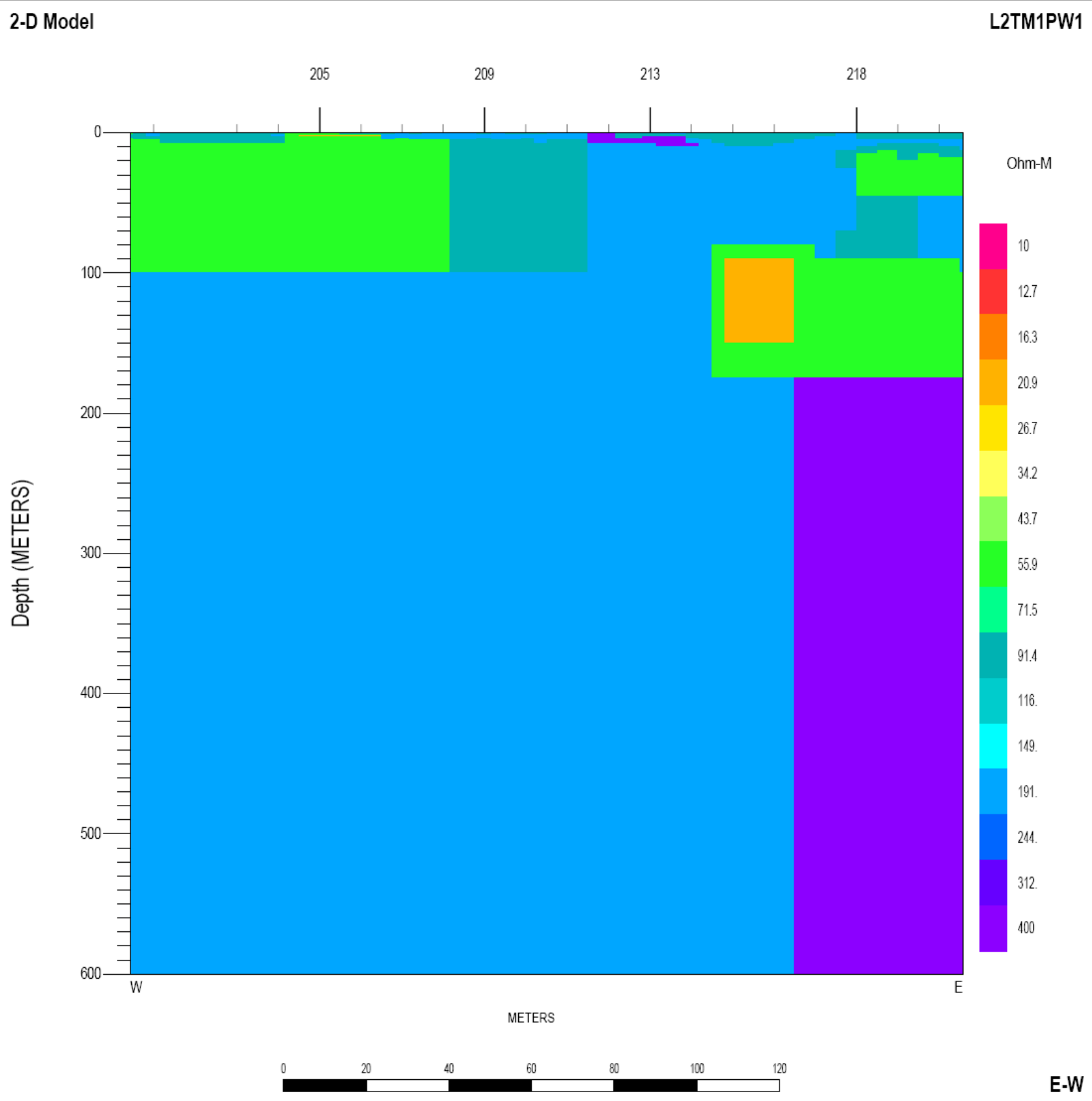

Figure B-67. Two-dimensional inversion model for Line 2 no finite difference mesh. 


\section{U.S. Geological Survey}

\section{Denver Federal Center}

Denver, Colorado 80225

MT Data for: L2

Date: $09 / 23 / 08$

\section{业Geotools}

MT Workstation

\section{by}

Geotools Corporation

5808 Balcones Dr. Suite 202

Austin, Texas 78731 USA

(512) $454-0679$

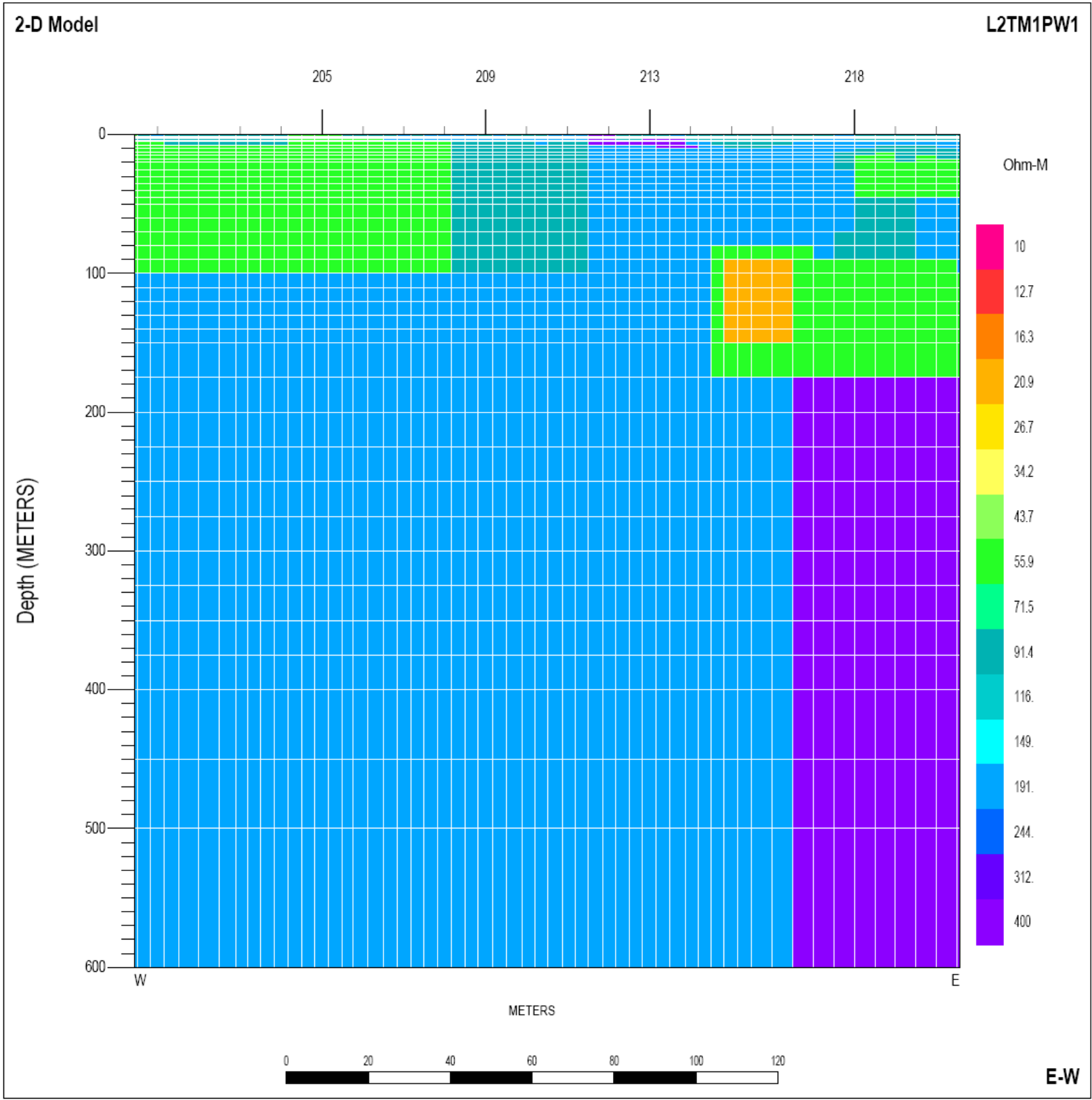

Figure B-68. Two-dimensional inversion model for Line 2 with finite difference mesh. 


\section{U.S. Geological Survey}

Denver Federal Center

Denver, Colorado 80225

MT Data for: L2

Date: 09/19/08

F Geotools

by

Gectools Corporation

5808 Balcones Dr. Suite 202

Austin, Texes 78731 USA

(512) 454.0679
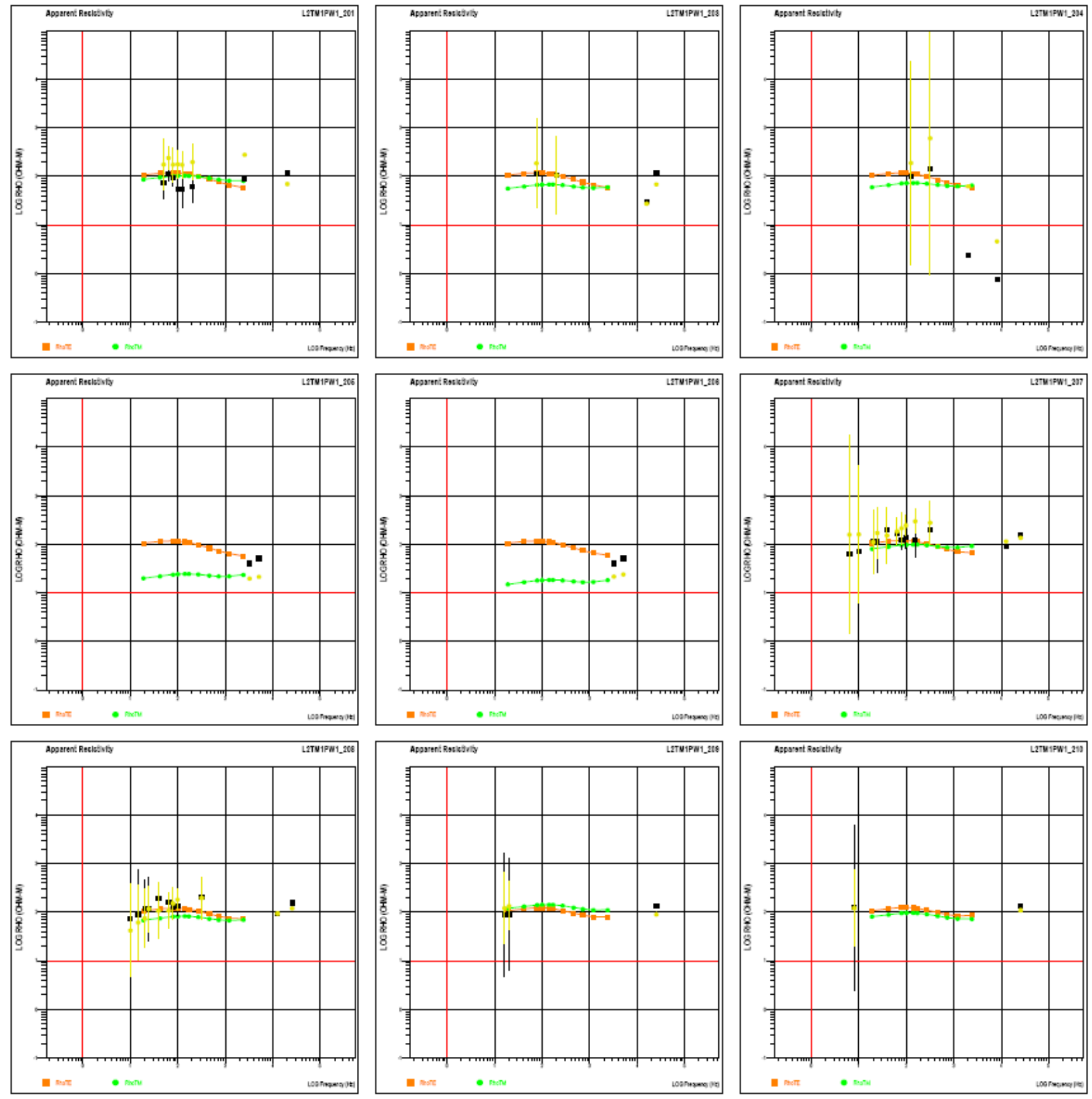

Figure B-69. Apparent resistivity data for Line 2, sites 1 to 10. 


\section{U.S. Geological Survey}

Denver Federal Center

Denver, Colorado 80225

MT Data for: L2

Date: 09/19/08
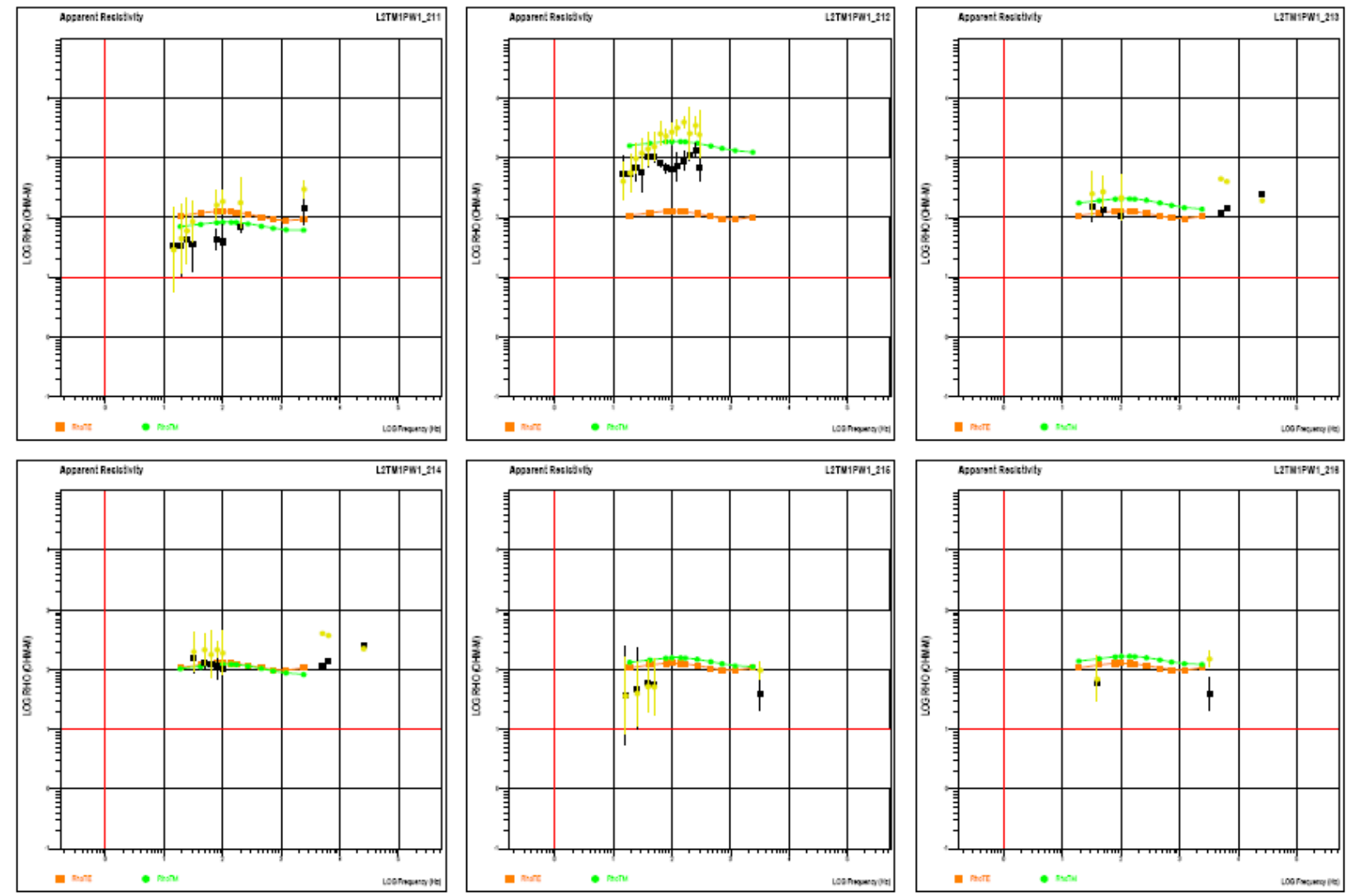

5008 Baccones Dr. Sulte 202

Austin, Texes 78731 USA

(512) 4540679
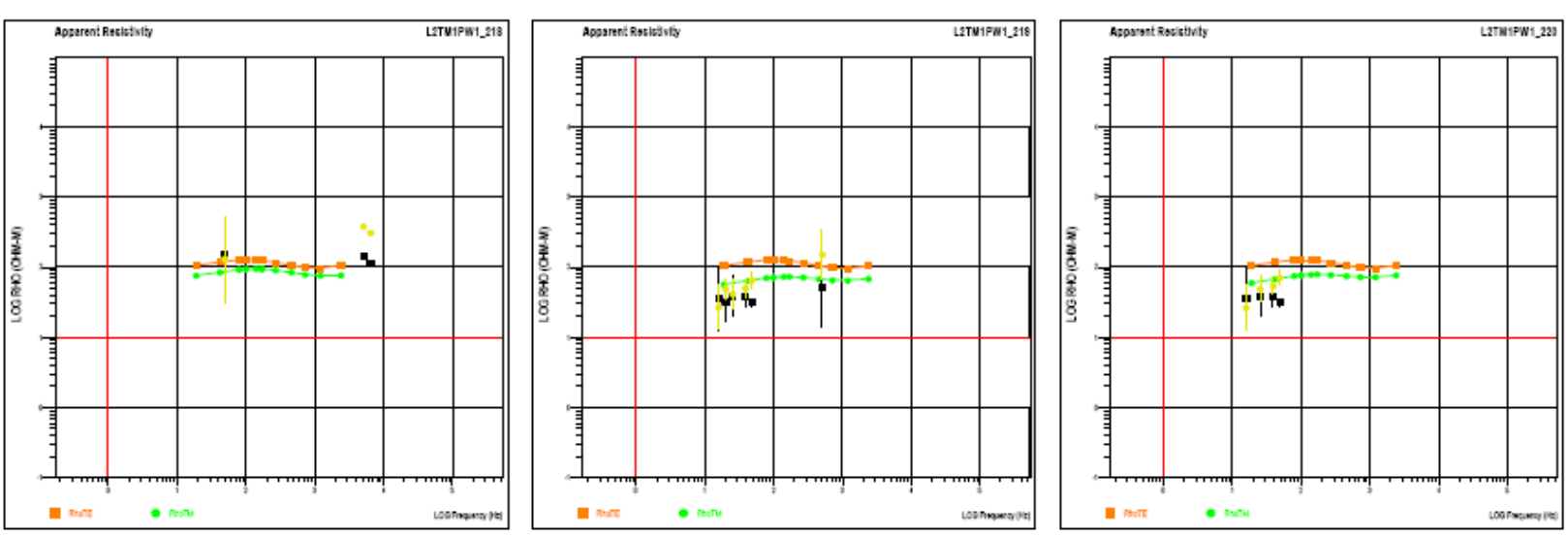

Figure B-70. Apparent resistivity data for Line 2, sites 11 to 20. 


\section{U.S. Geological Survey}

Denver Federal Center

Denver, Colorado 80225

MT Data for: L2

Date: 09/19/08
F Geotools

by

Geotools Corporation

5008 Balcones Dr. Sulte 202

Austin, Texes 78731 USA

(512) 454.0679
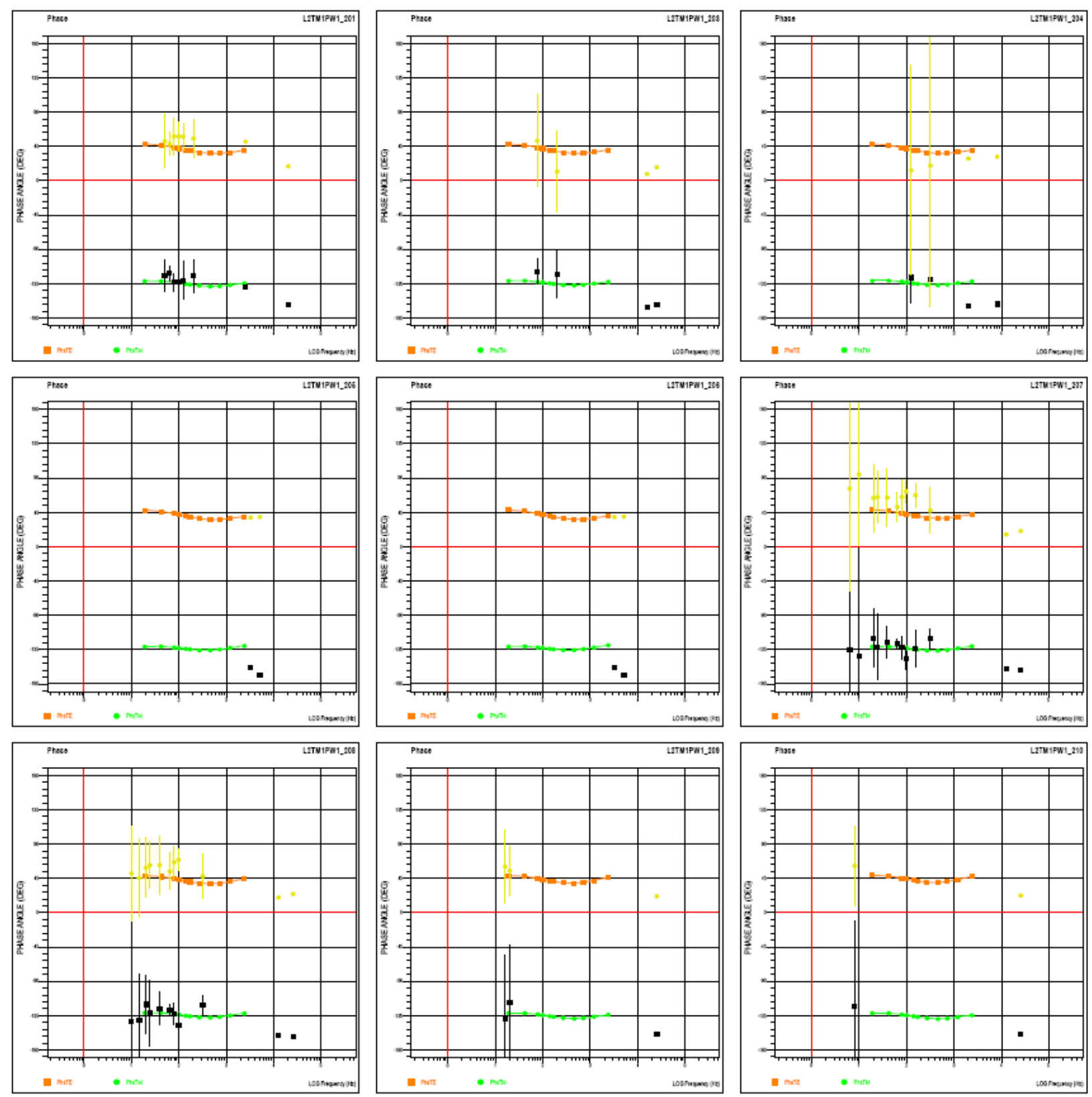

Figure B-71. Phase data for Line 2, sites 1 to 10. 


\section{U.S. Geological Survey}

Denver Federal Center

Denver, Colorado 80225

MT Data for: L2

Date: 09/19/08
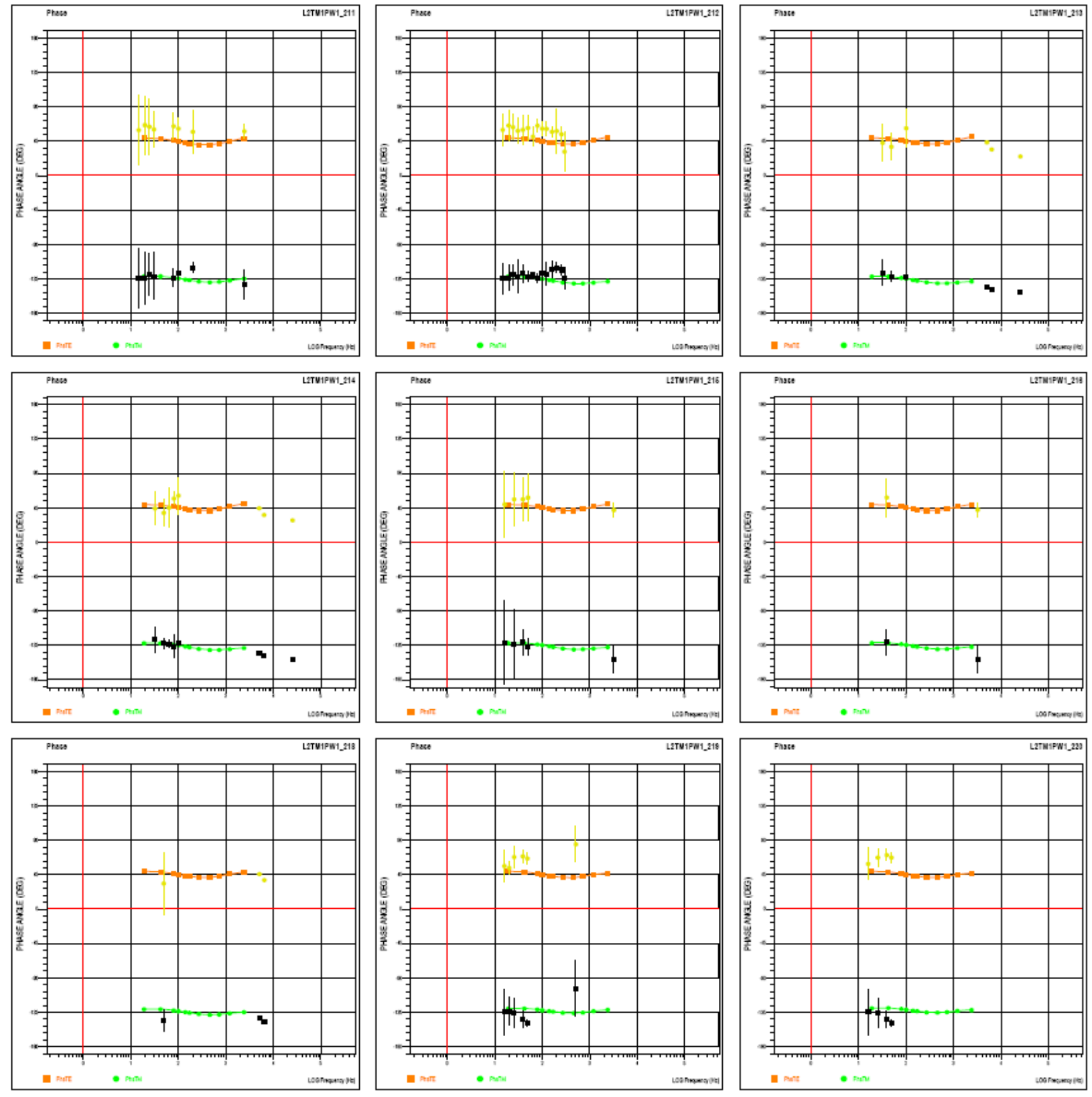

Figure B-72. Phase data for Line 2, sites 11 to 20. 

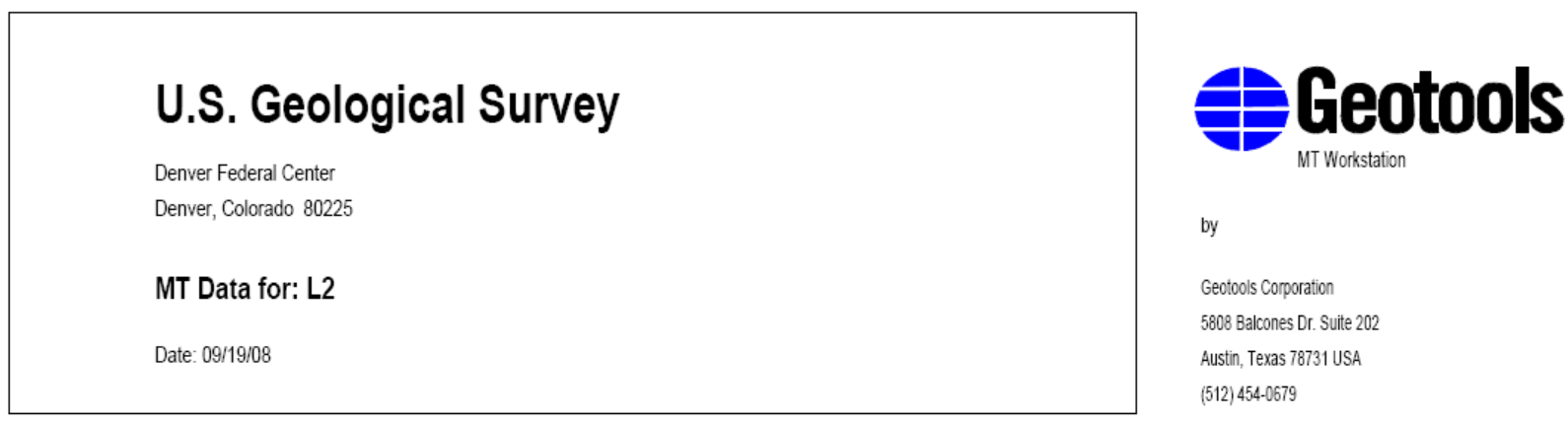

by

Geotools Corporation

5808 Balcones Dr. Suite 202

Austin, Texas 78731 USA

(512) $454-0679$
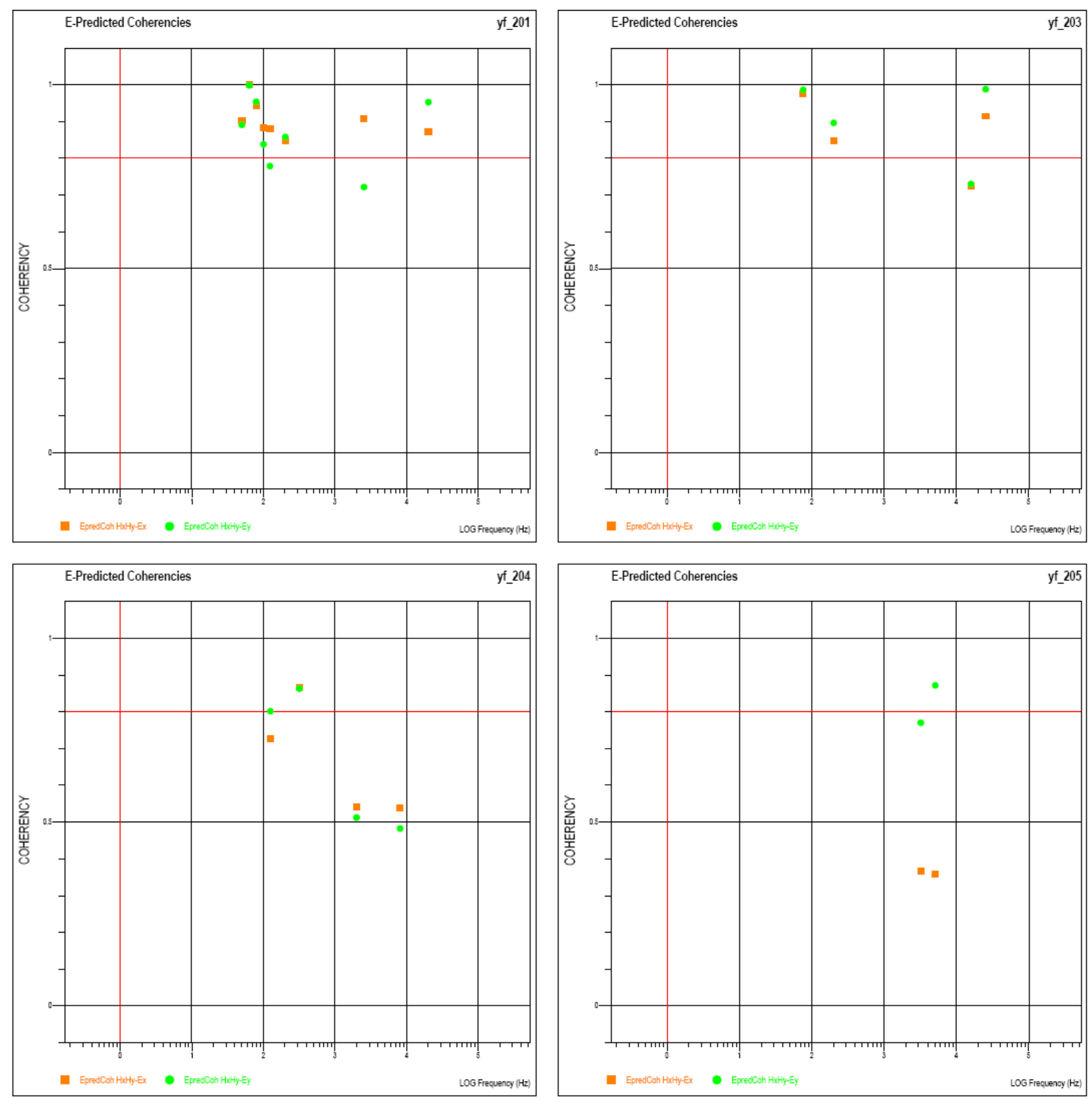

Figure B-73. E-predicted coherencies for Line 2, sites 1 to 5. 


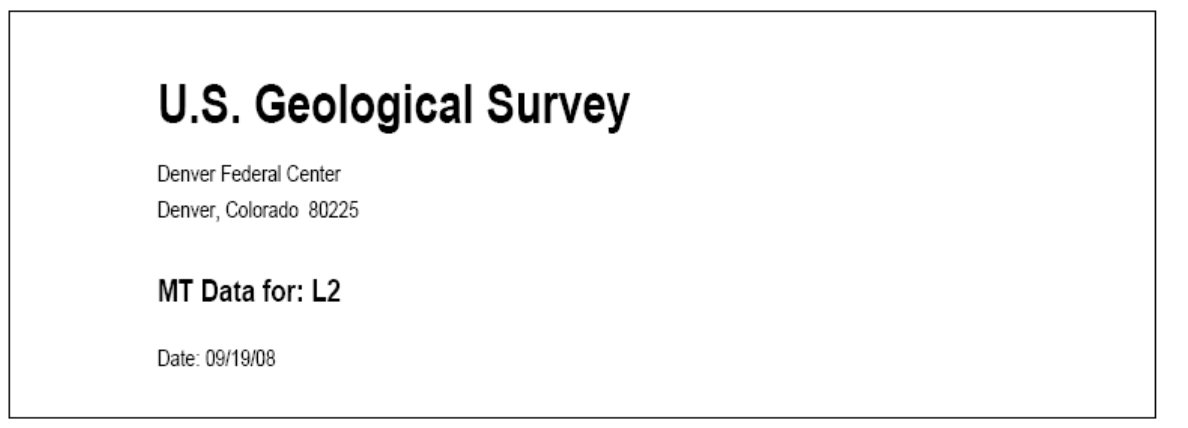

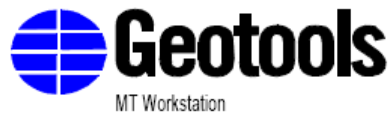

by

Geotools Corporation

5808 Balcones Dr. Suite 202

Austin, Texas 78731 USA

(512) $454-0679$
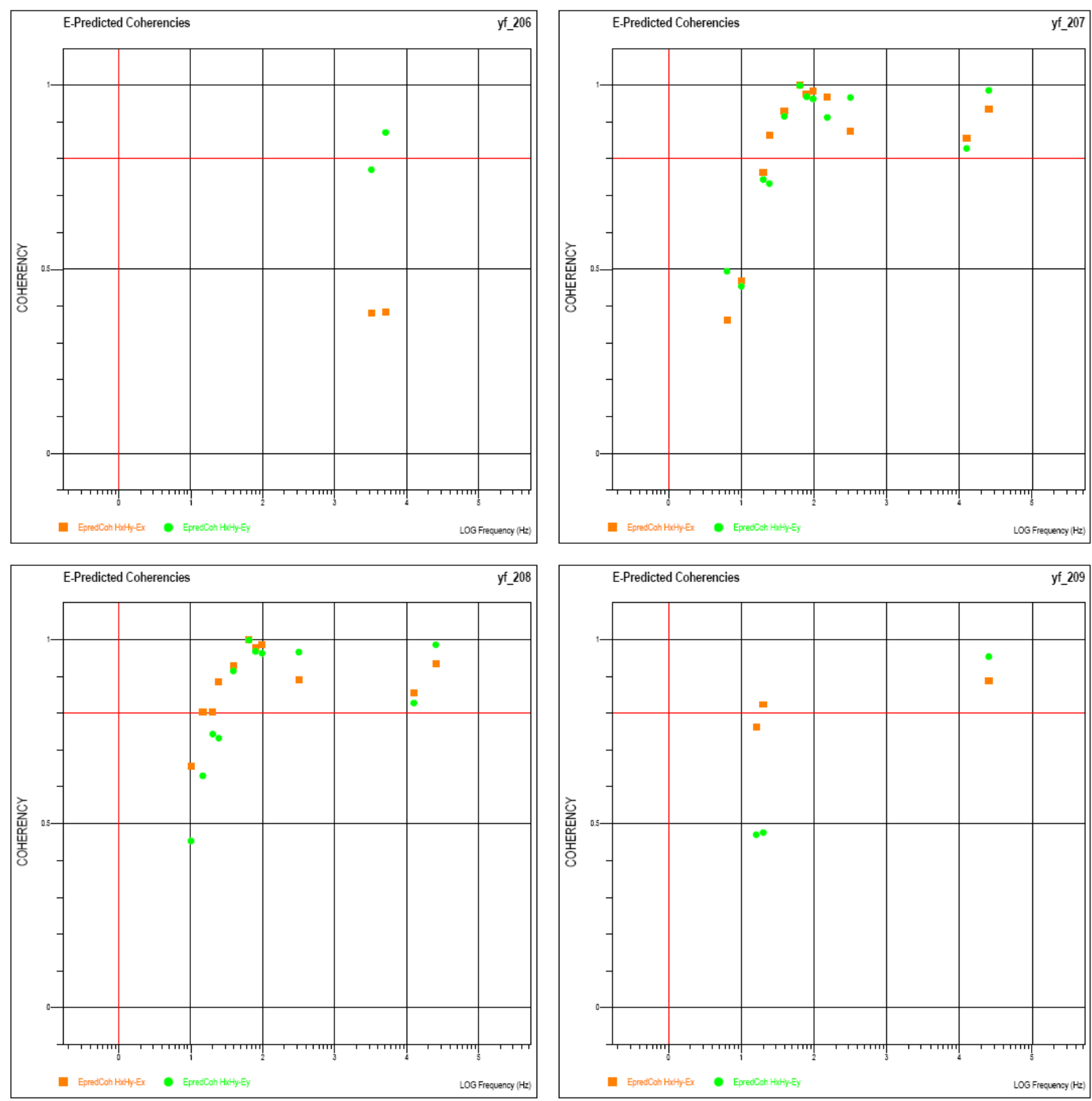

Figure B-74. E-predicted coherencies for Line 2, sites 6 to 9 . 

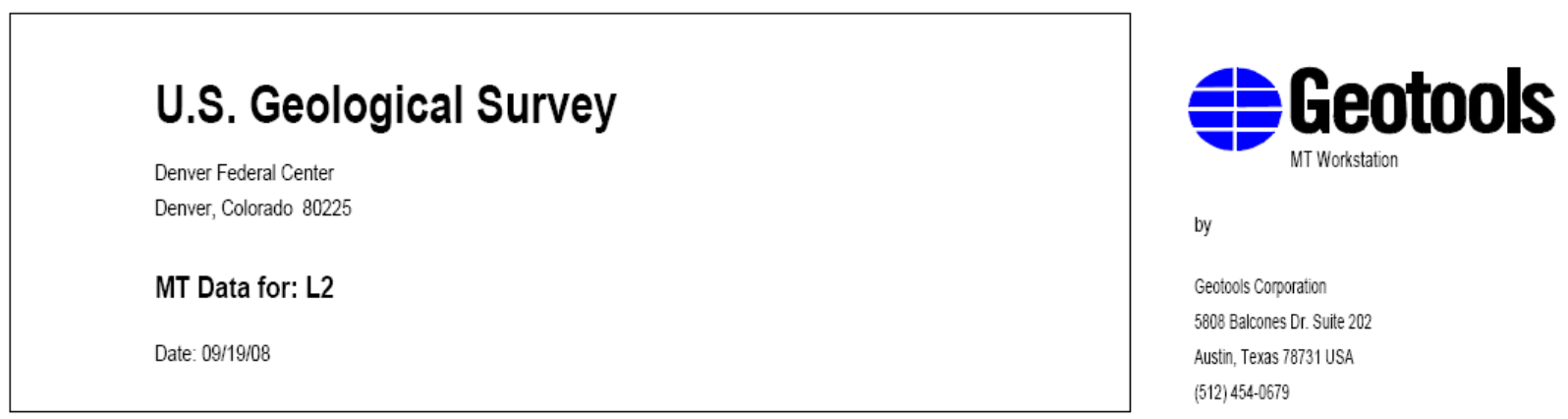

by

Geotools Corporation

5808 Balcones Dr. Suite 202

Austin, Texas 78731 USA

(512) 454-0679
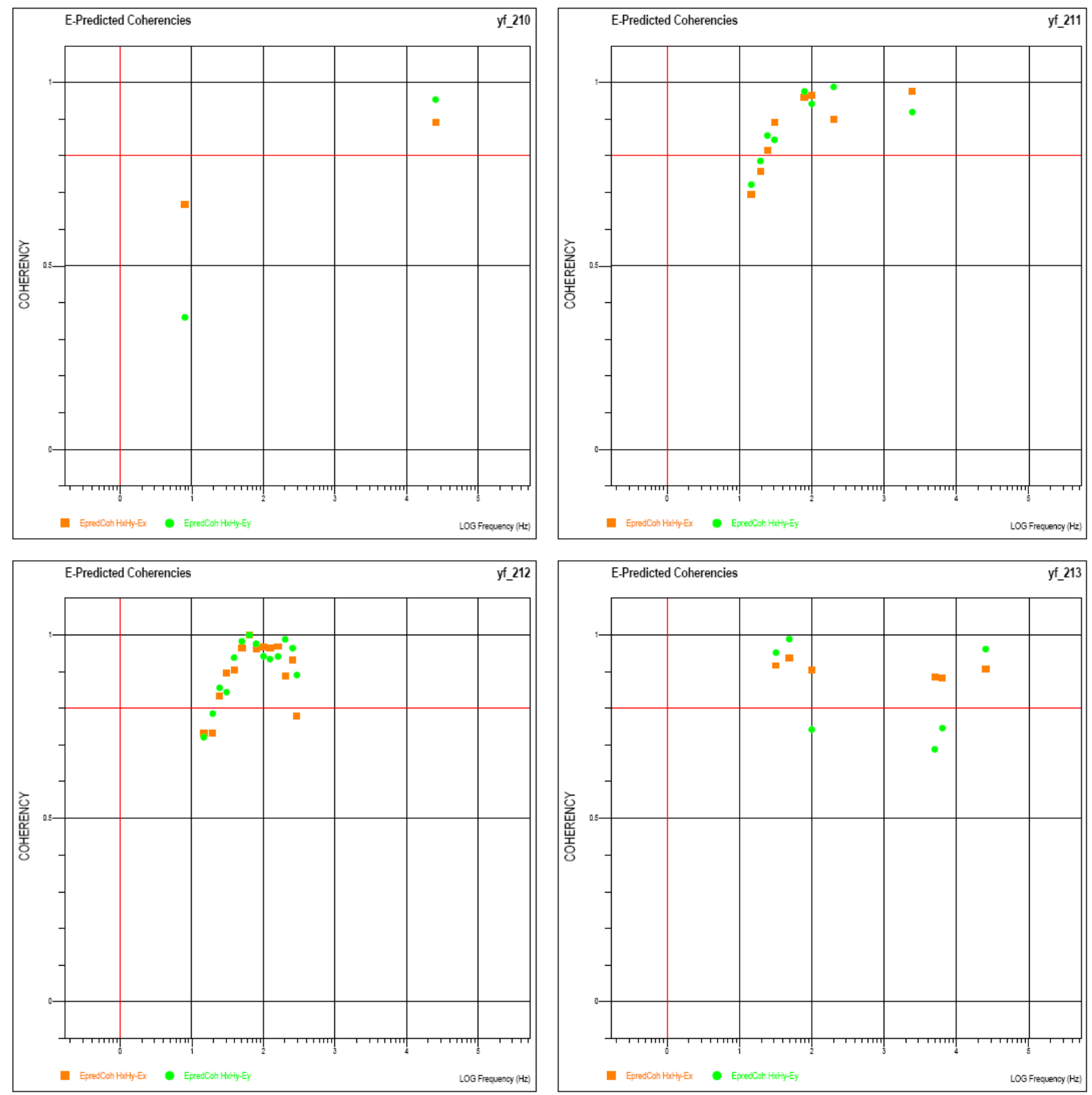

Figure B-75. E-predicted coherencies for Line 2, sites 10 to 13. 


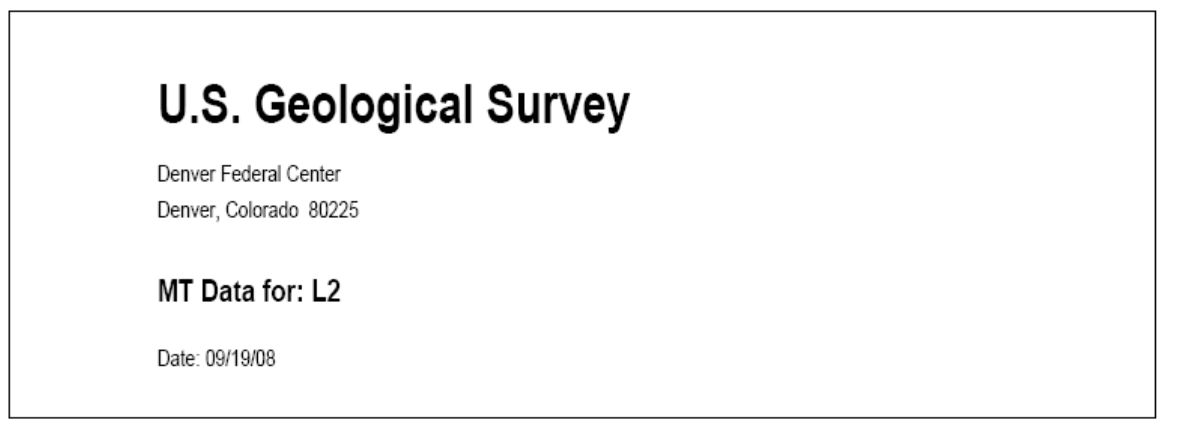

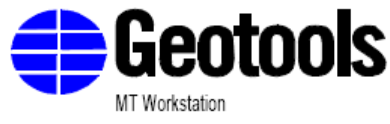

by

Geotools Corporation

5808 Balcones Dr. Suite 202

Austin, Texas 78731 USA

(512) $454-0679$
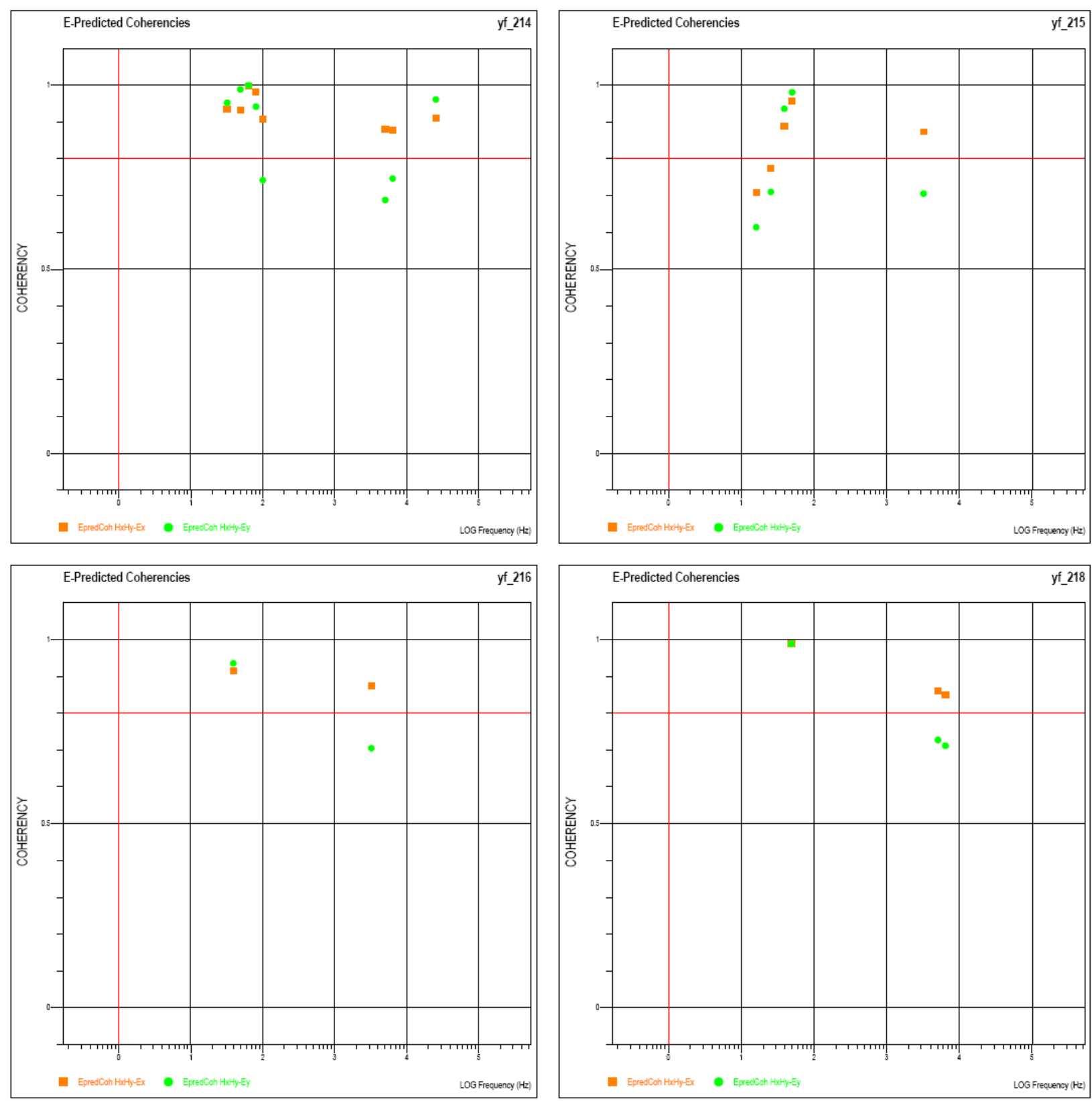

Figure B-76. E-predicted coherencies for Line 2, sites 14 to 18 . 


\section{U.S. Geological Survey}

Denver Federal Center

Denver, Colorado 80225

MT Data for: L2

Date: 09/19/08

拝Geotools

MT Workstation

by

Geotools Corporation

5808 Balcones Dr. Suite 202

Austin, Texas 78731 USA

(512) 454-0679
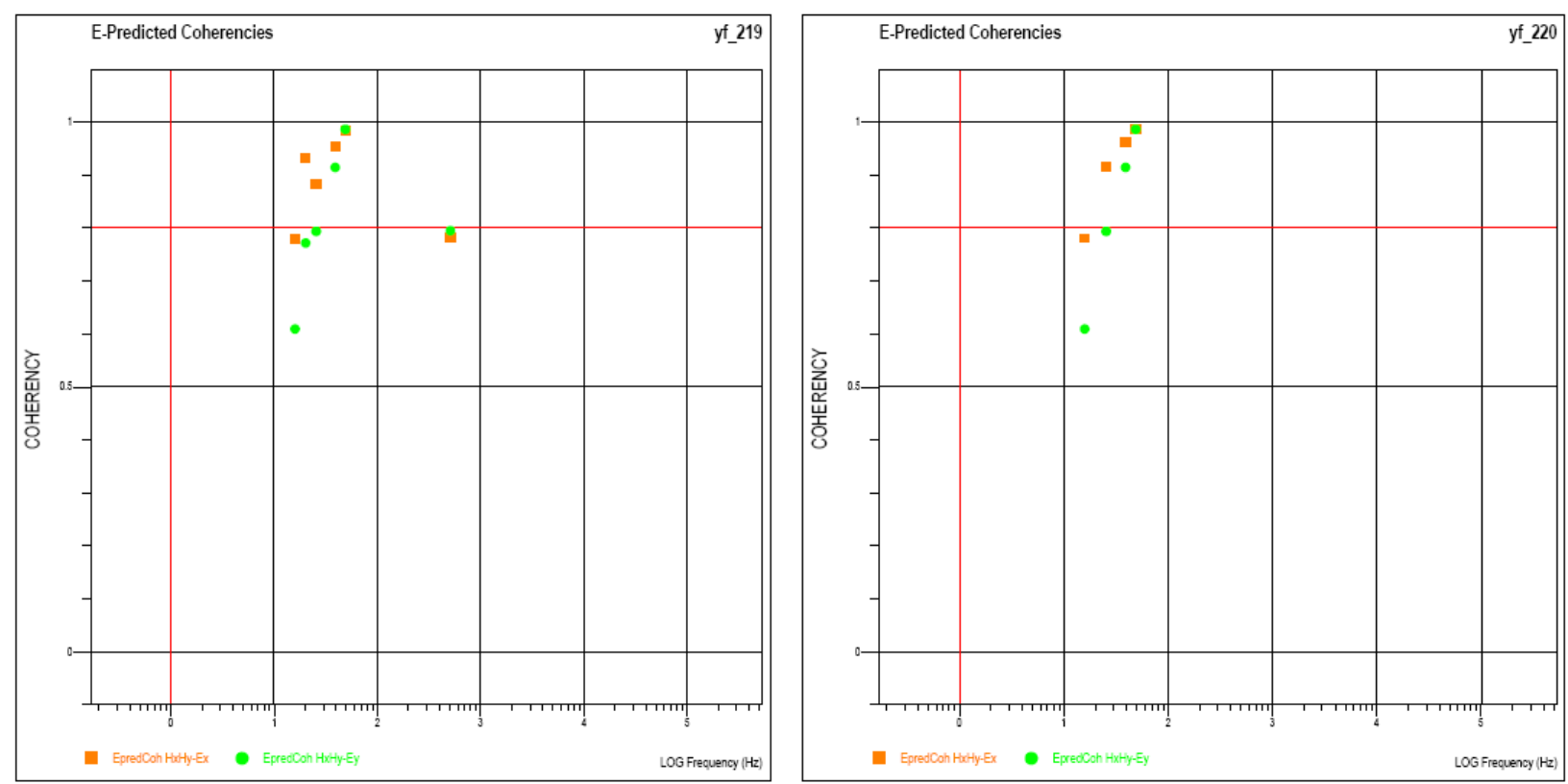

Figure B-77. E-predicted coherencies for Line 2, sites 19 to 20. 


\section{U.S. Geological Survey}

Denver Federal Center

Denver, Colorado 80225

MT Data for: L2

Date: 09/19/08

拝Geotools

MT Workstation

by

Geotools Corporation

5808 Balcones Dr. Suite 202

Austin, Texas 78731 USA

(512) 454-0679
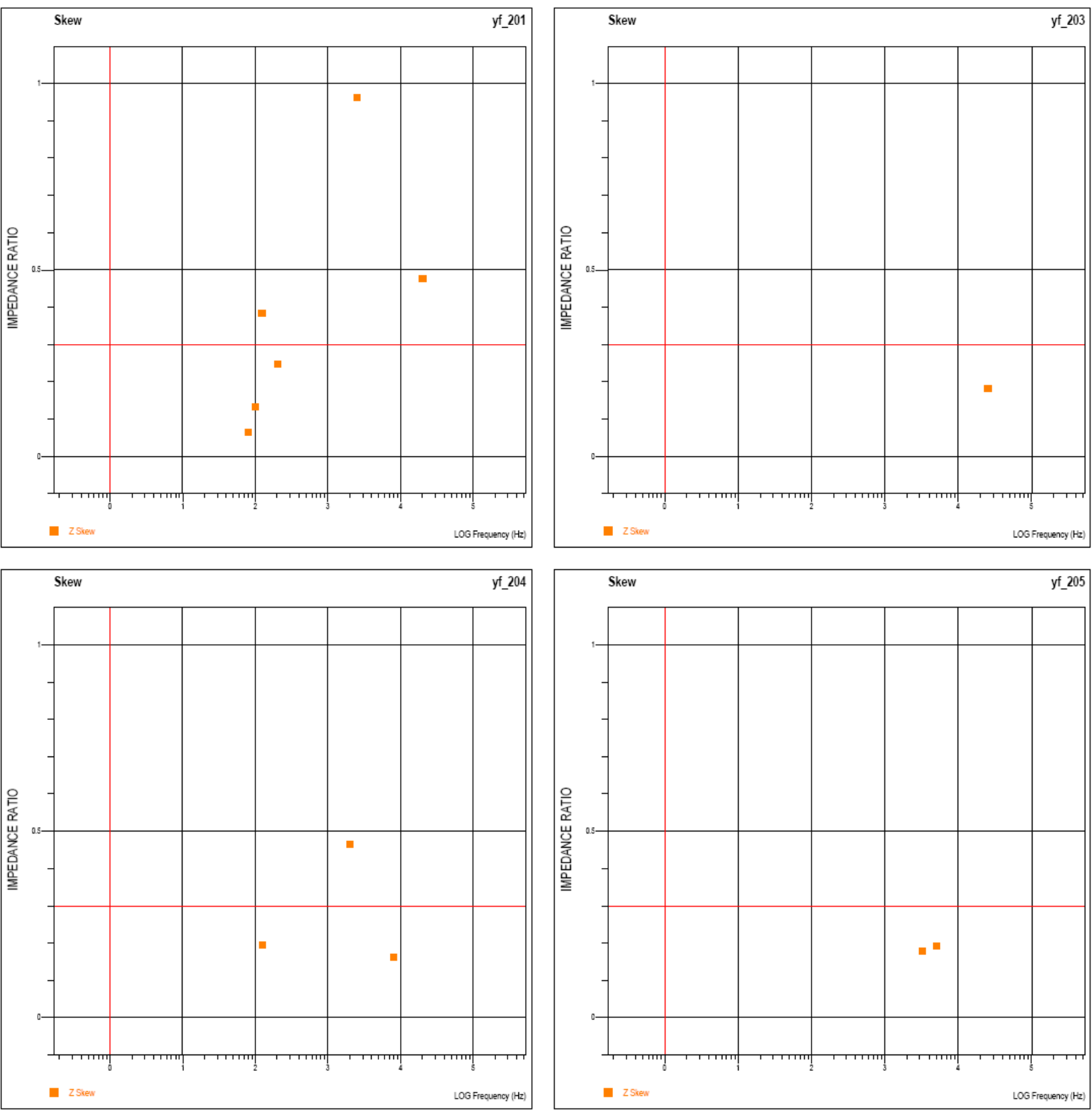

Figure B-78. Impedance skews for Line 2, sites 1 to 5. 


\section{U.S. Geological Survey}

Denver Federal Center

Denver, Colorado 80225

MT Data for: L2

Date: 09/19/08

FGeotools

MT Workstation

by

Geotools Corporation

5808 Balcones Dr. Suite 202

Austin, Texas 78731 USA

(512) $454-0679$
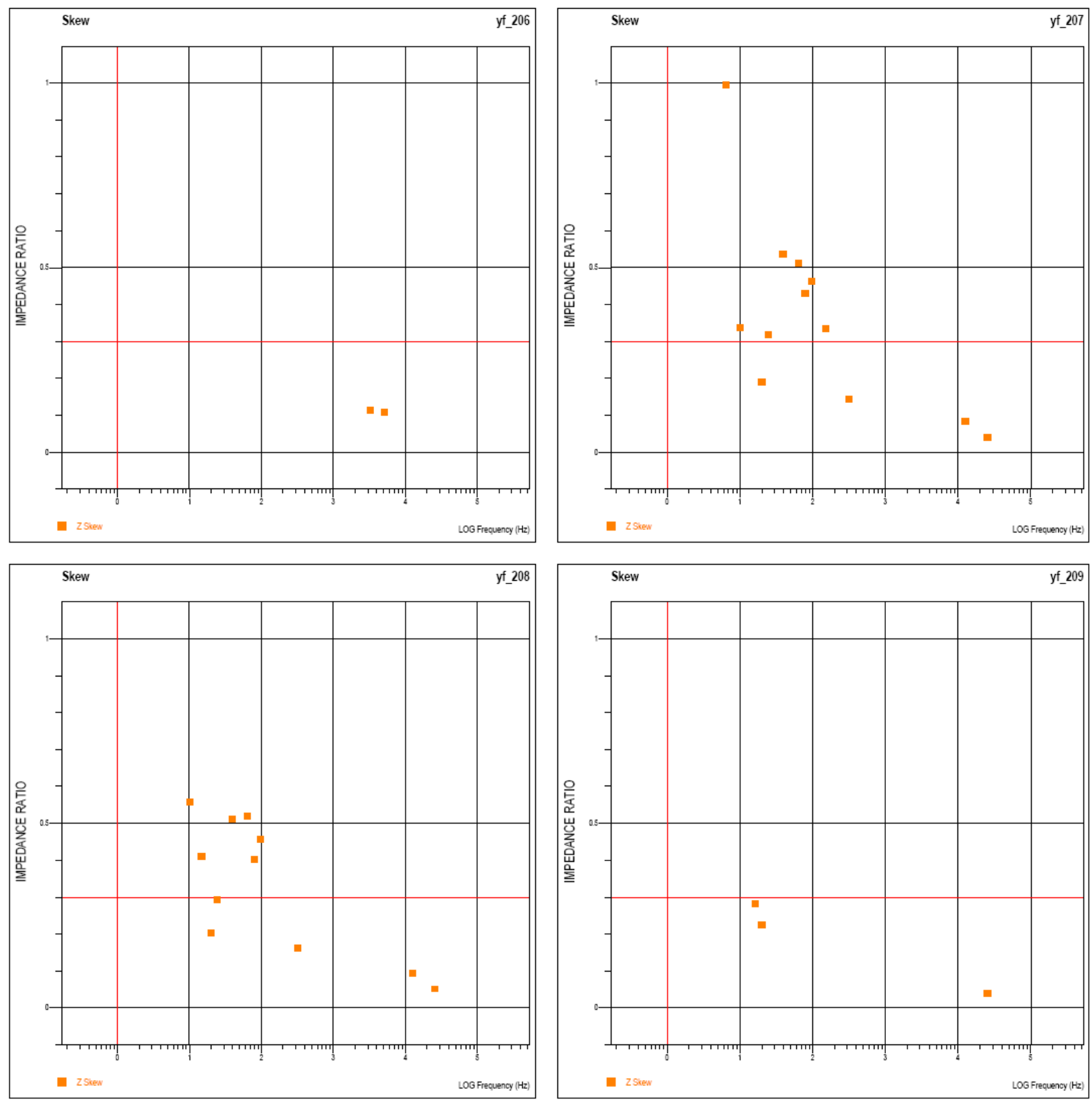

Figure B-79. Impedance skews for Line 2, sites 6 to 9. 


\section{U.S. Geological Survey}

Denver Federal Center

Denver, Colorado 80225

MT Data for: L2

Date: 09/19/08
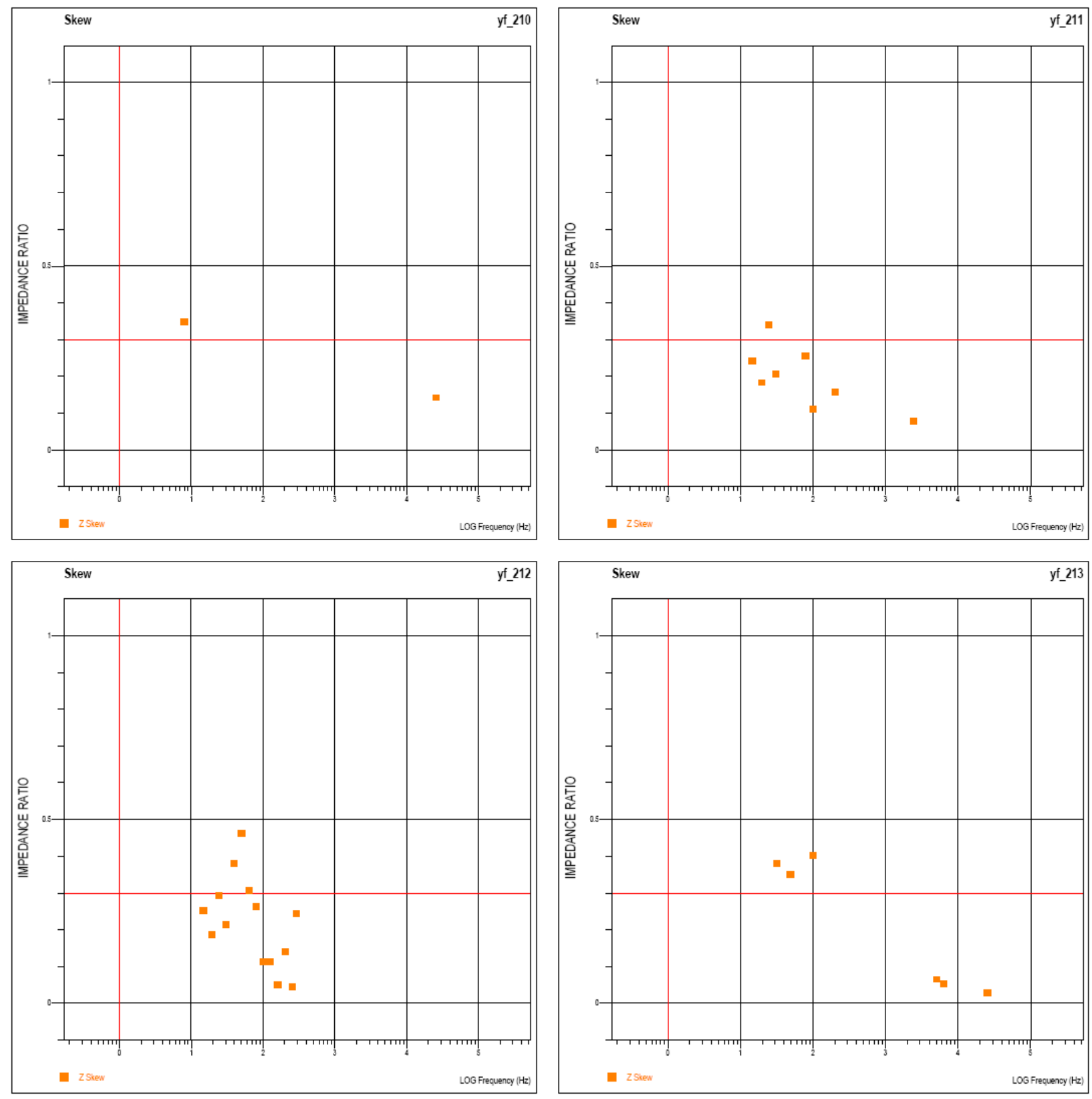

Figure B-80. Impedance skews for Line 2, sites 10 to 13. 


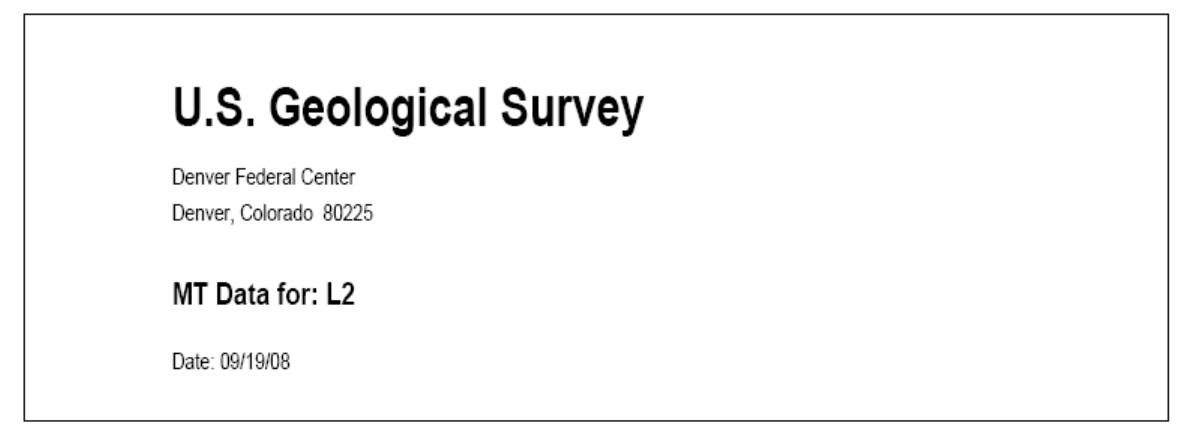

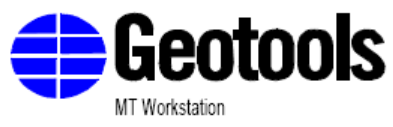

by

Geotools Corporation

5808 Balcones Dr. Suite 202

Austin, Texas 78731 USA

(512) $454-0679$
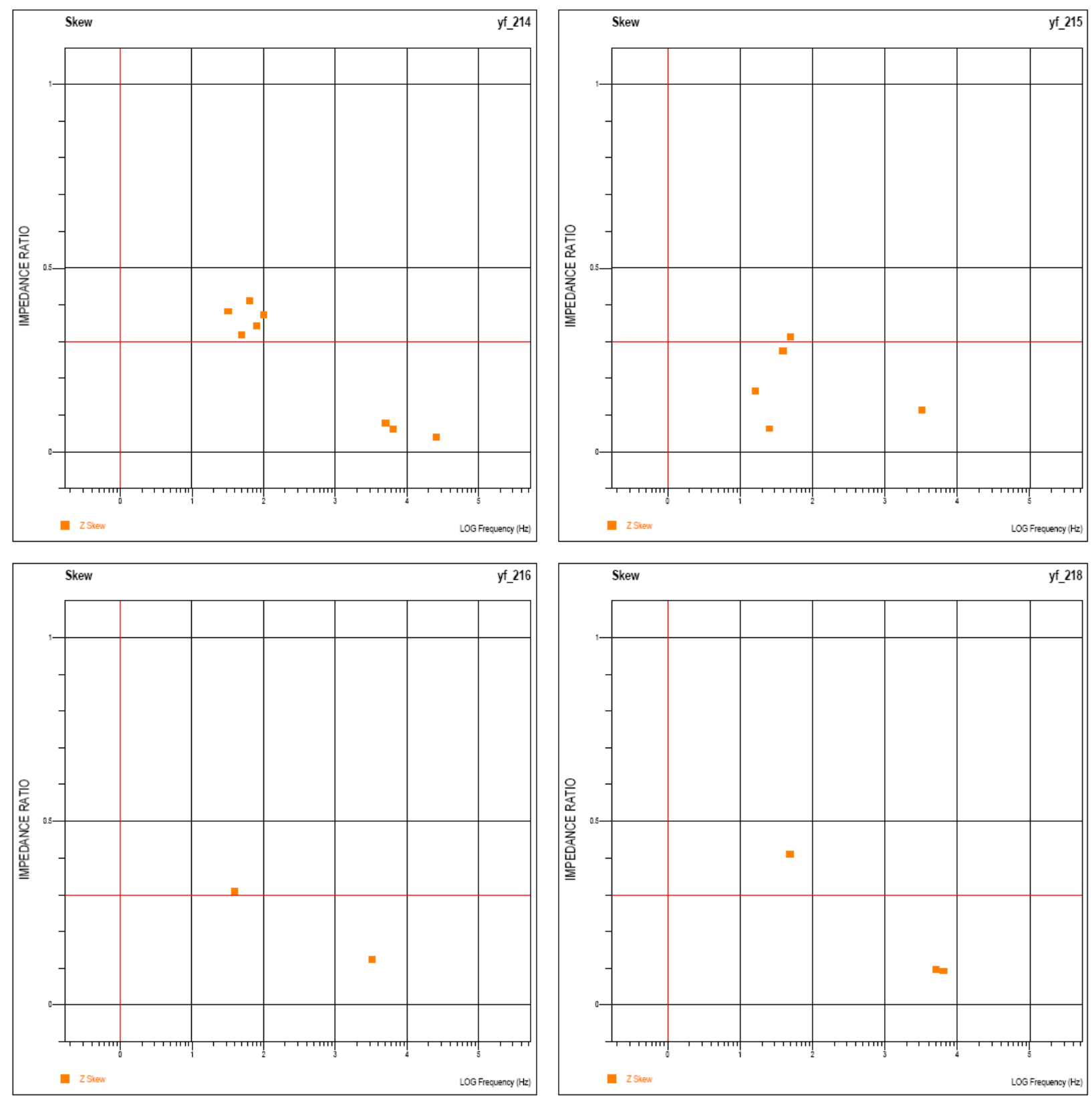

Figure B-81. Impedance skews for Line 2, sites 14 to 18. 

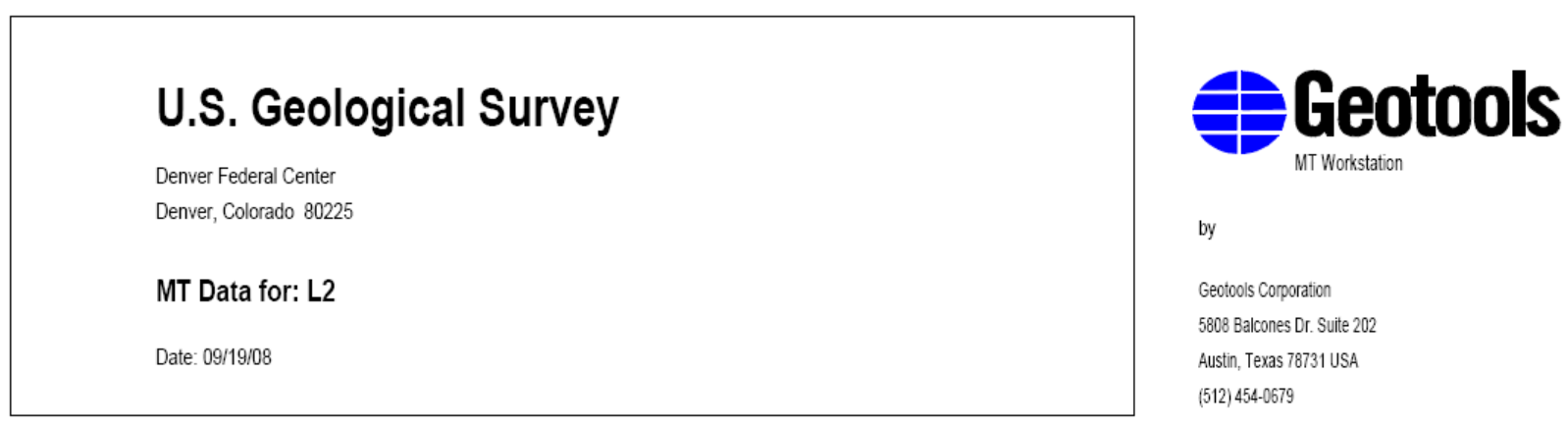

by

Geotools Corporation

5808 Balcones Dr. Suite 202

Austin, Texas 78731 USA

(512) 454-0679
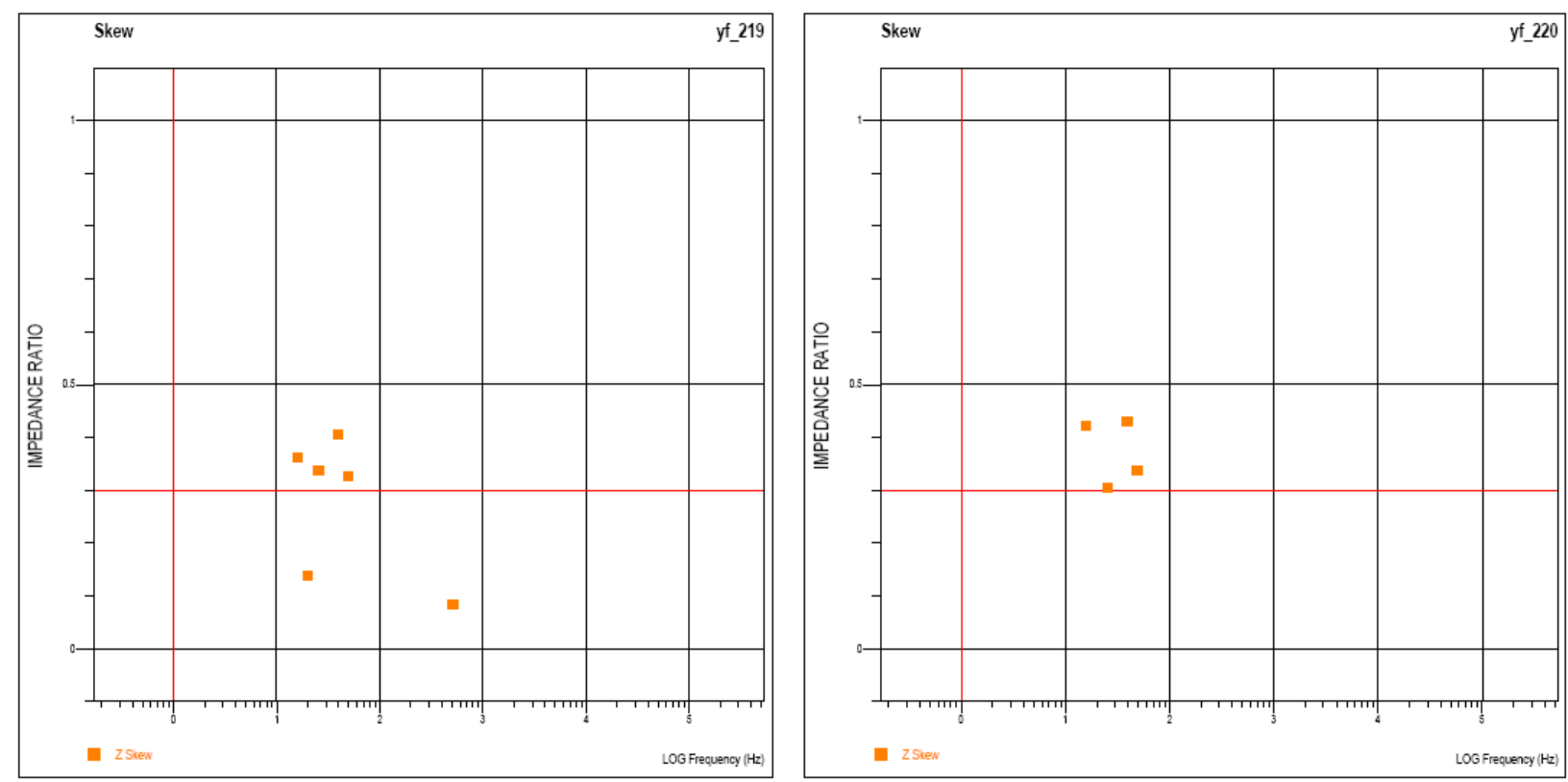

Figure B-82. Impedance skews for Line 2, sites 19 to 20. 


\section{U.S. Geological Survey}

Denver Federal Center

Denver, Colorado 80225

MT Data for: L2

Date: 09/18/08
F Geotools

MT Workstation

by

Geotools Corporation

5808 Balcones Dr. Sute 202

Austin, Texas 78731 USA

(512) 454-0679
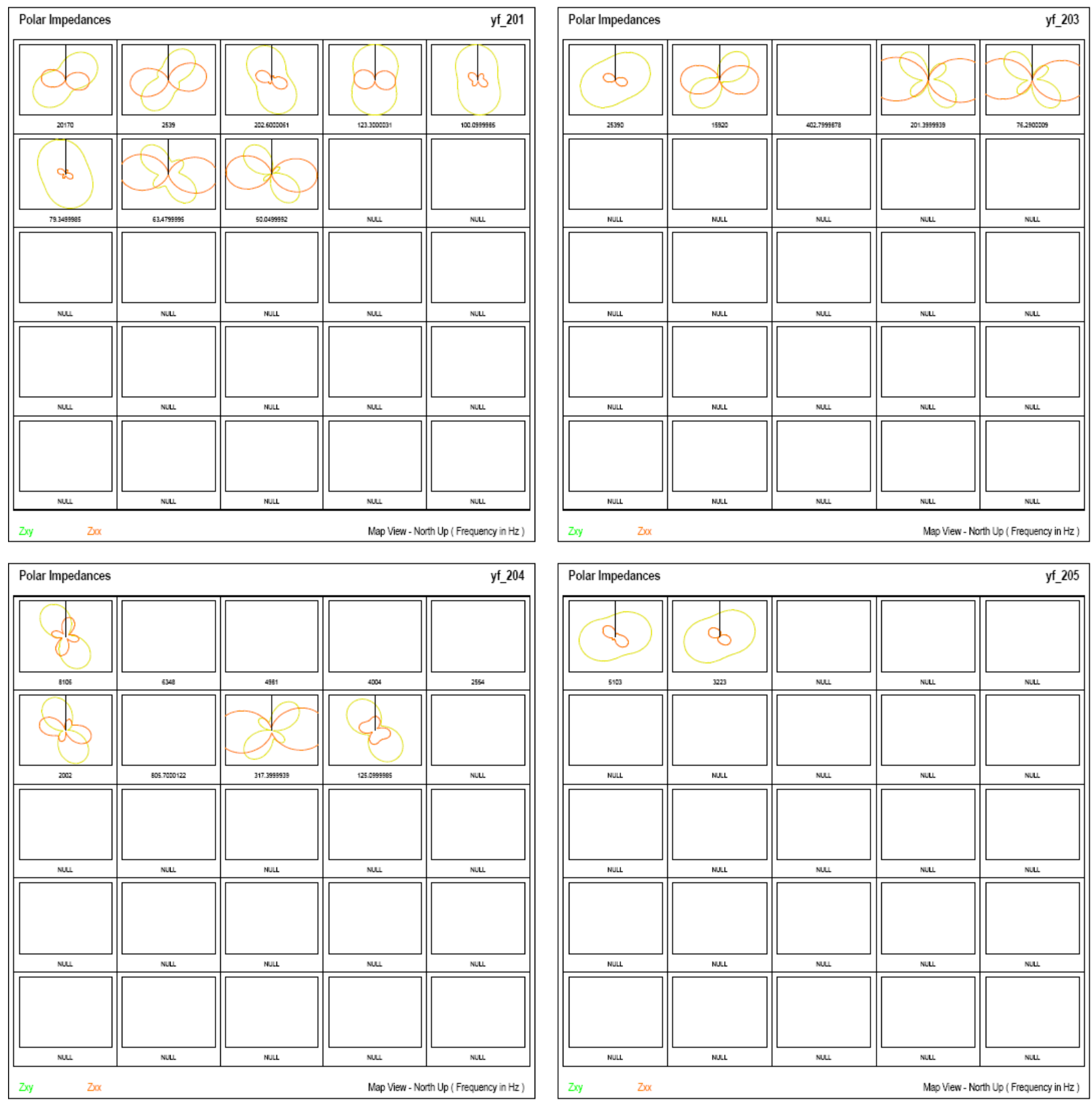

Figure B-83. Polar impedance plots for Line 2, sites 1 to 5. 


\section{U.S. Geological Survey}

Denver Federal Center

Denver, Colorado 80225

MT Data for: L2

Date: 09/18/08
F Geotools

by

Geotools Corporation

5808 Balcones Dr. Suite 202

Austin, Texas 78731 USA

(512) 454-0679
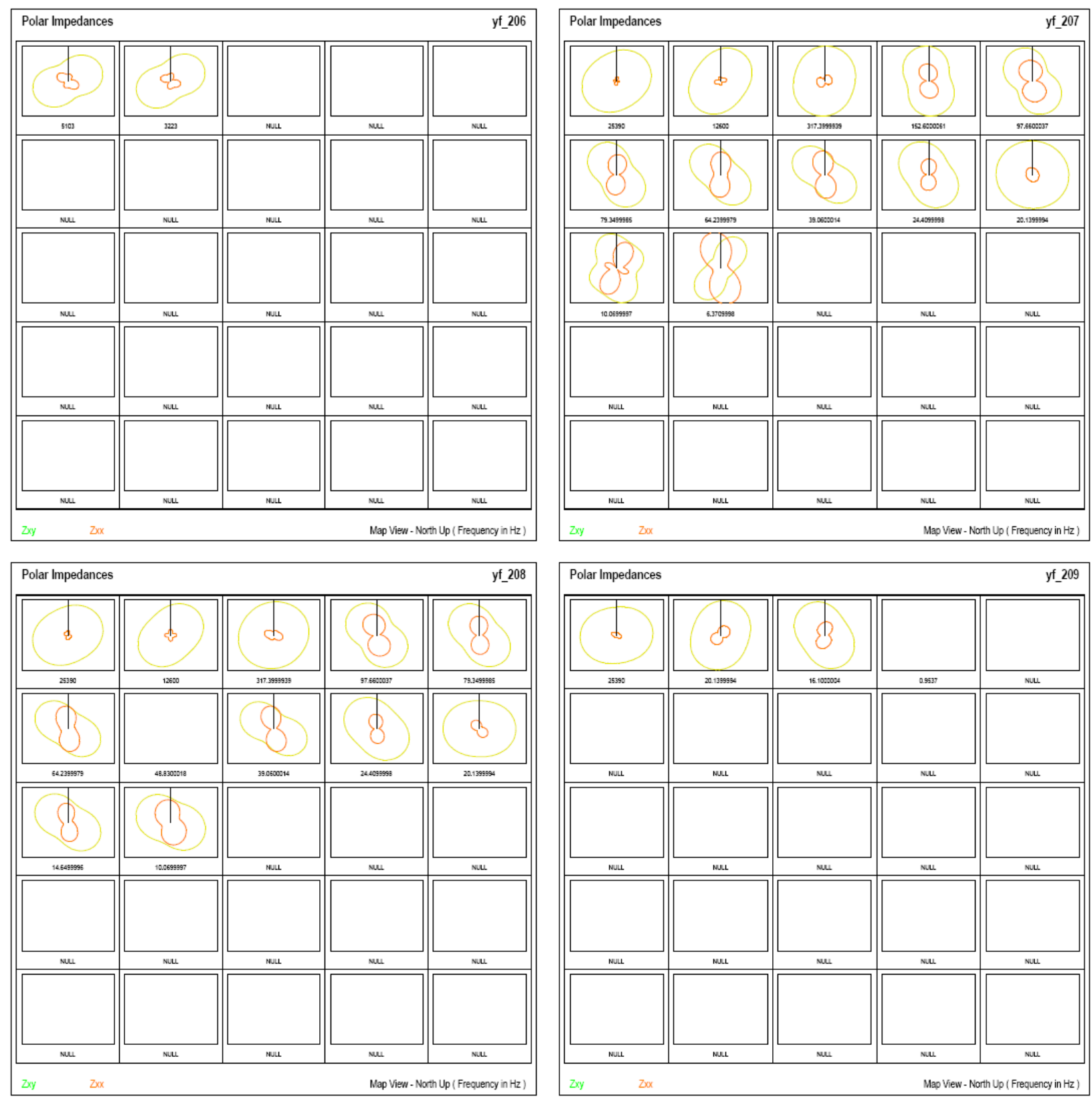

Figure B-84. Polar impedance plots for Line 2, sites 6 to 9. 


\section{U.S. Geological Survey}

Denver Federal Center

Denver, Colorado 80225

MT Data for: L2

Date: 09/18/08

F Geotools

by

Geotools Corporation

5808 Balcones Dr. Sutte 202

Austin, Texas 78731 USA

(512) 454-0679
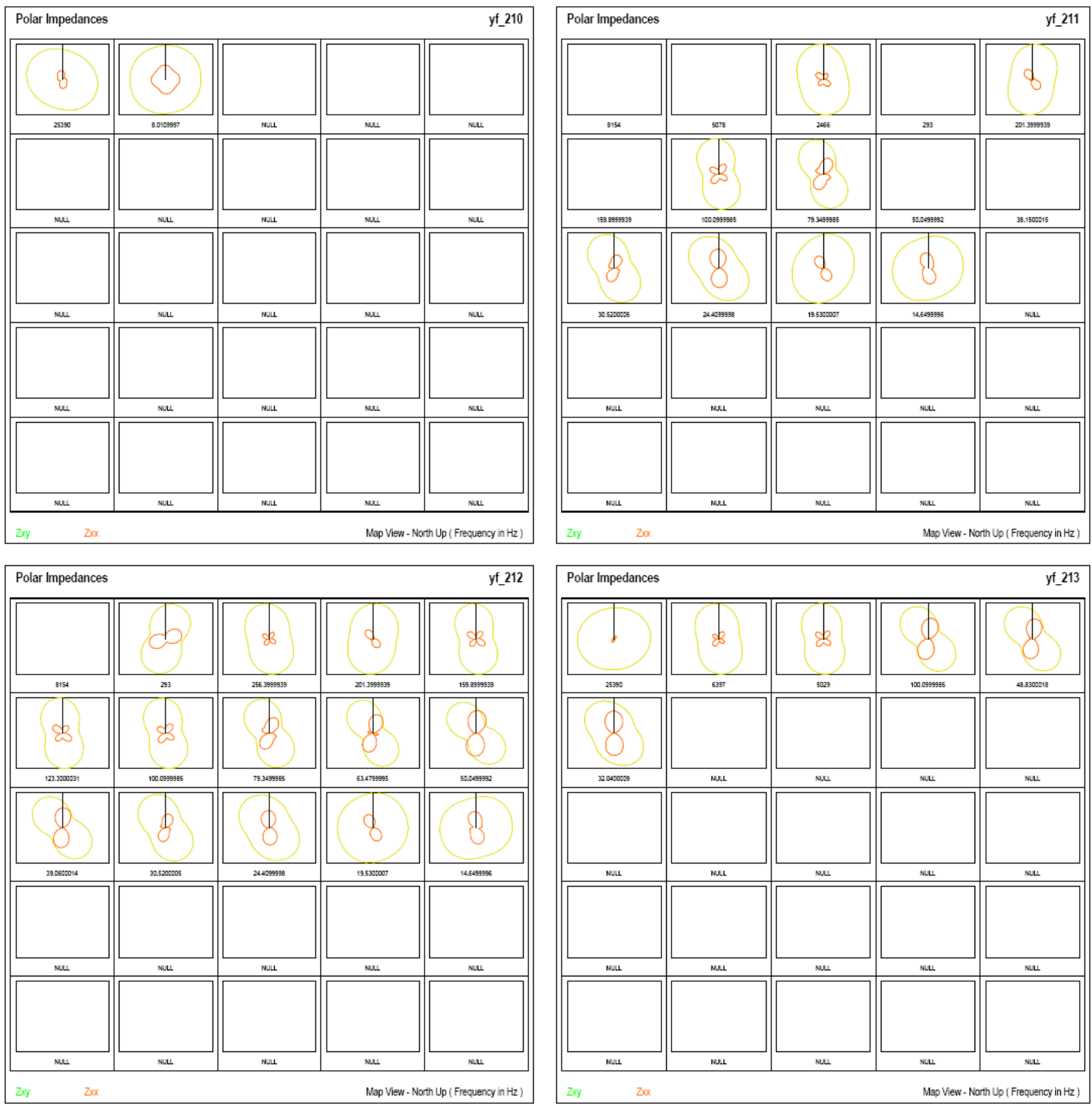

Figure B-85. Polar impedance plots for Line 2, sites 10 to 13. 


\section{U.S. Geological Survey}

Denver Federal Center

Denver, Colorado 80225

MT Data for: L2

Date: 09/18/08
FGeotools

MT Workstation

by

Geotools Corporation

5808 Balcones Dr. Suite 202

Austin, Texas 78731 USA

(512) $454-0679$
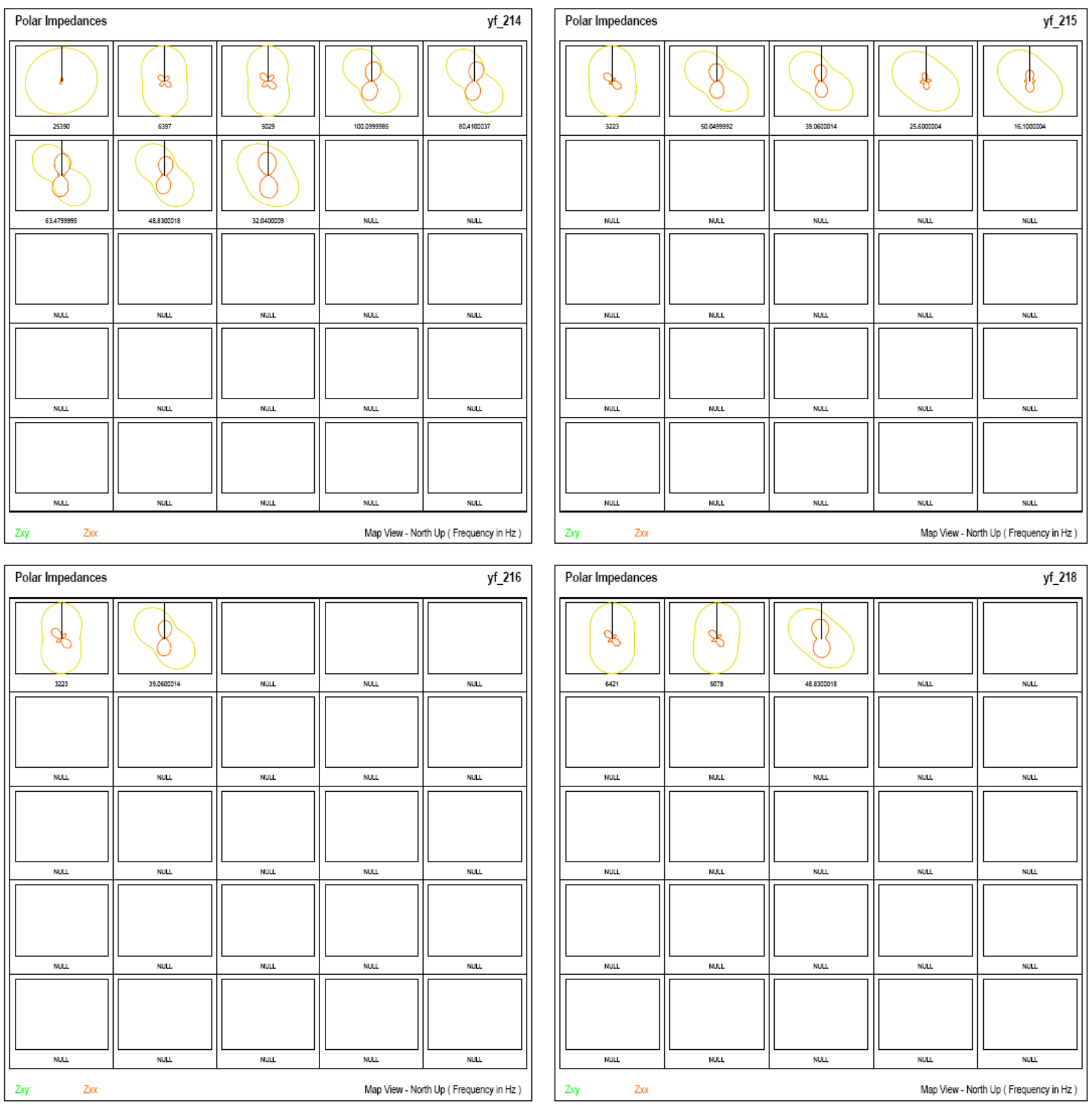

Figure B-86. Polar impedance plots for Line 2, sites 14 to 18 . 


\section{U.S. Geological Survey}

Denver Federal Center

Denver, Colorado 80225

MT Data for: L2

Date: 09/18/08

\section{䡒Geotools \\ MT Workstation}

by

Geotools Corporation

5808 Balcones Dr. Sulte 202

Austin, Texas 78731 USA

(512) 454-0679
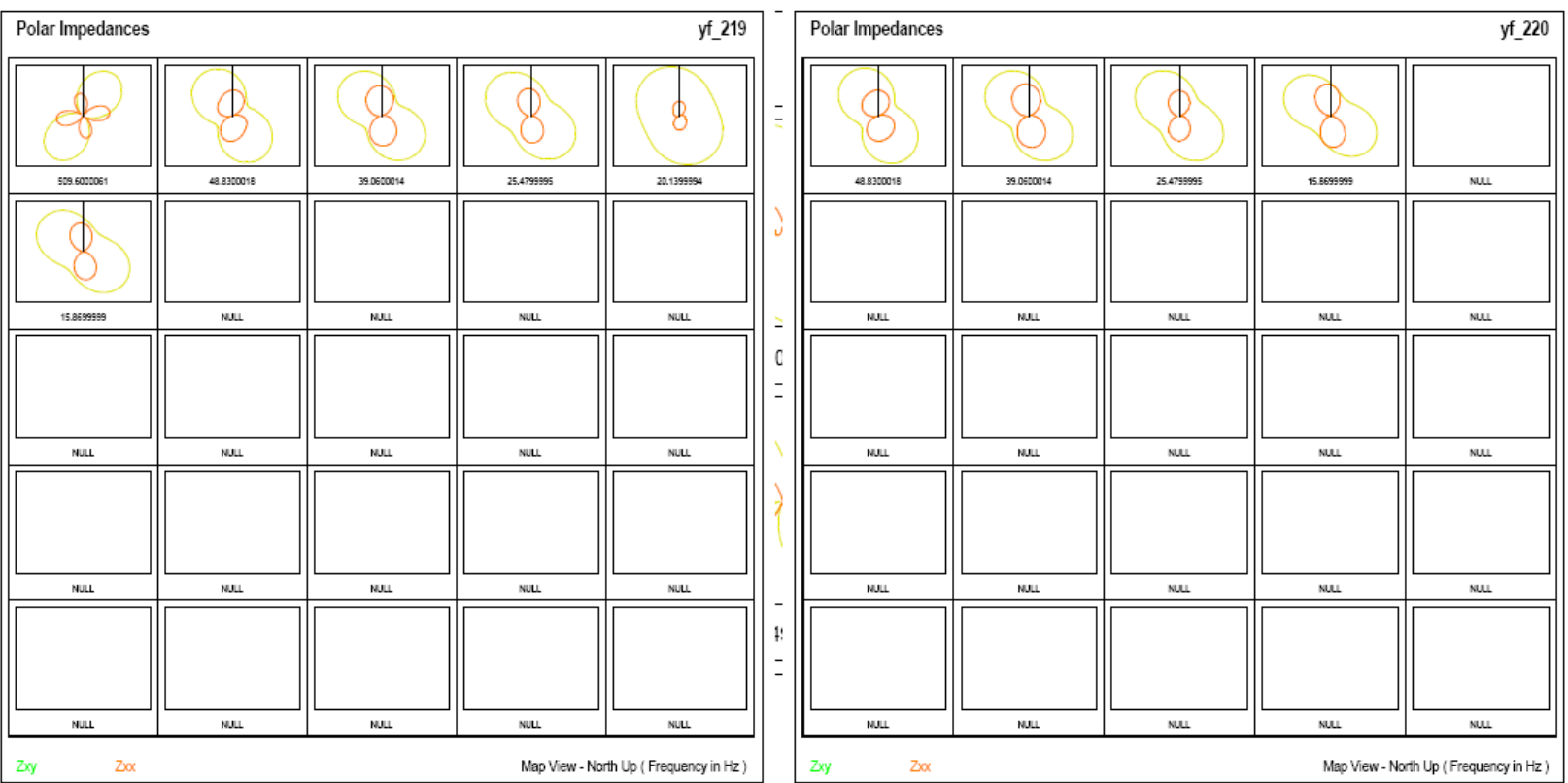

Figure B-87. Polar impedance plots for Line 2, sites 19 to 20. 


\section{U.S. Geological Survey}

Denver Federal Center

Denver, Colorado 80225

MT Data for: L2

Date: $09 / 19 / 08$
FGeotools

by

Geotools Corporation

5808 Balcones Dr. Suite 202

Austin, Texas 78731 USA

(512) $454-0679$
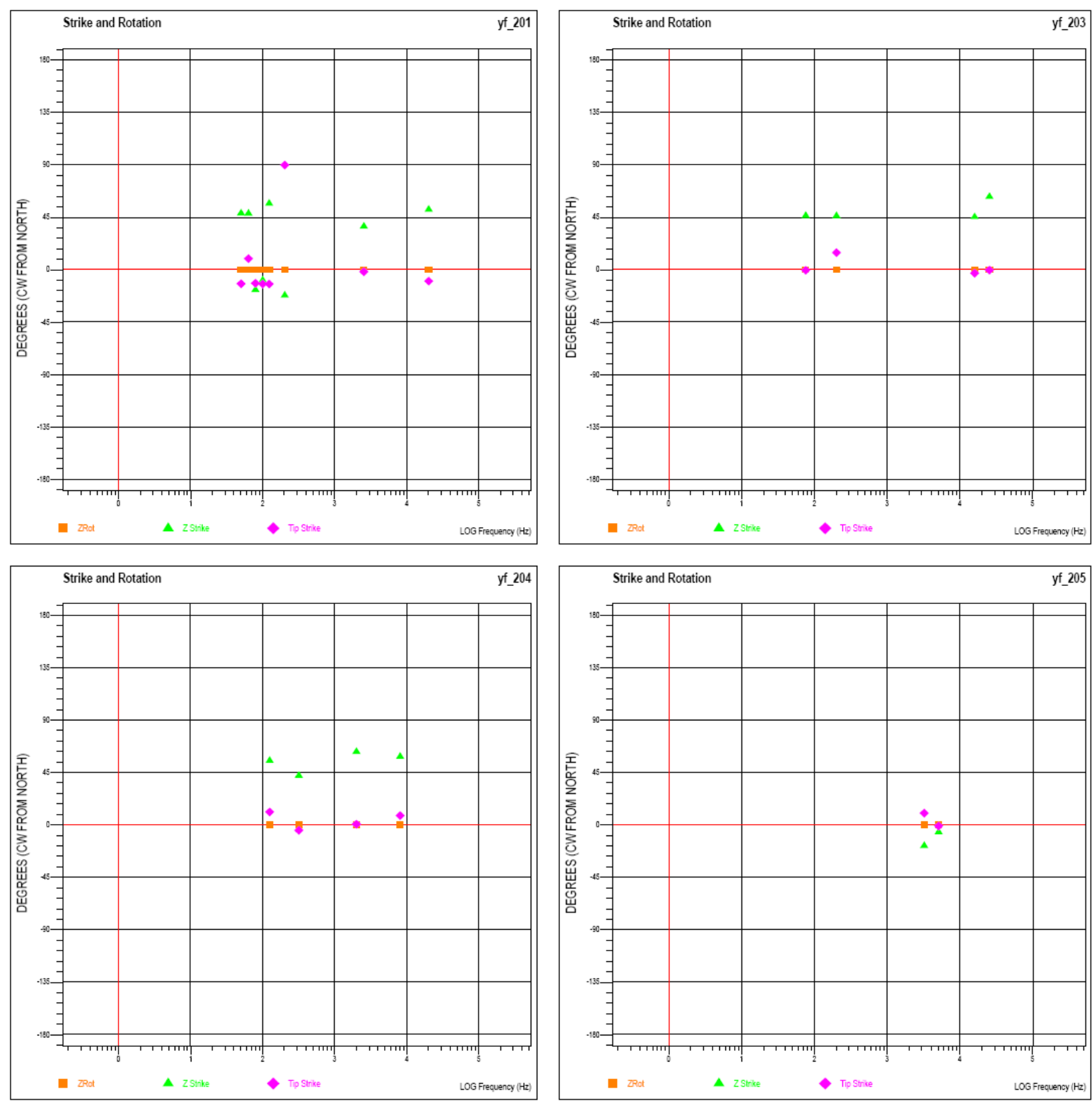

Figure B-88. Impedance strike, rotation, and tipper strike for Line 2, sites 1 to 5. 


\section{U.S. Geological Survey}

\section{Denver Federal Center}

Denver, Colorado 80225

MT Data for: L2

Date: 09/19/08
专Geotools

MT Workstation

by

Geotools Corporation

5808 Balcones Dr. Suite 202

Austin, Texas 78731 USA

(512) 454-0679
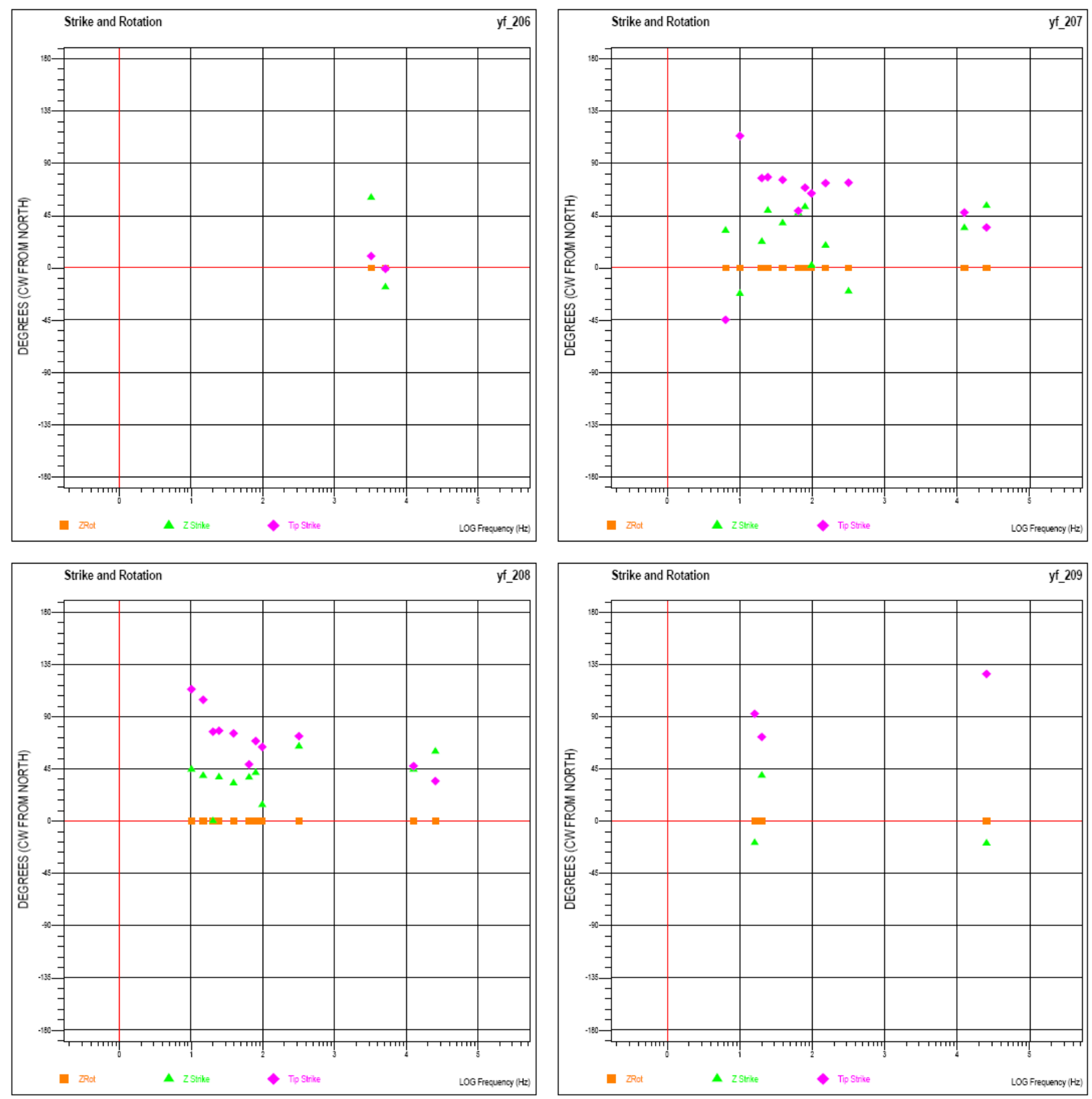

Figure B-89. Impedance strike, rotation, and tipper strike for Line 2, sites 6 to 9 . 


\section{U.S. Geological Survey}

Denver Federal Center

Denver, Colorado 80225

MT Data for: L2

Date: 09/19/08
F Geotools

MT Workstation

by

Geotools Corporation

5808 Balcones Dr. Suite 202

Austin, Texas 78731 USA

(512) 454-0679
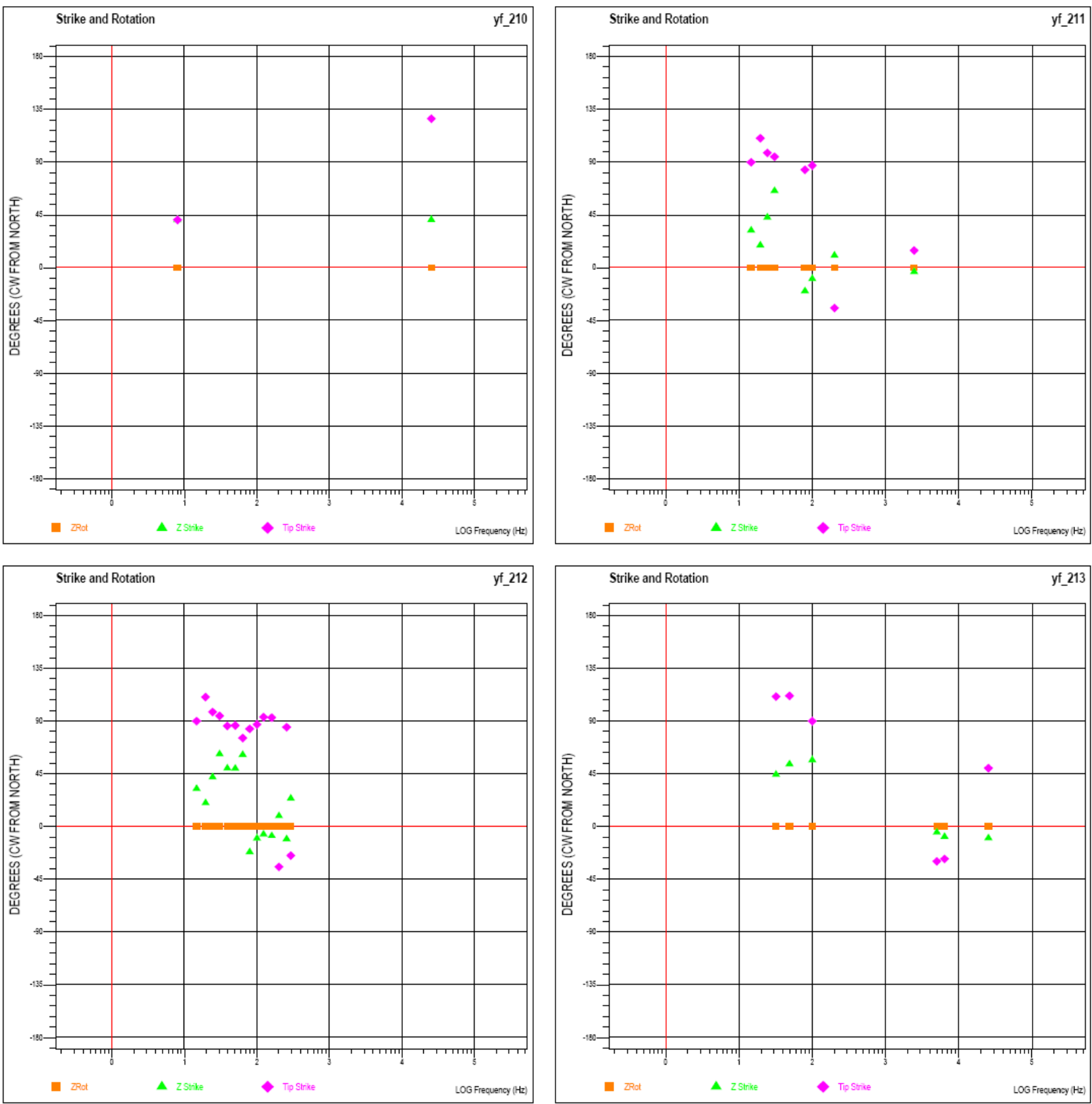

Figure B-90. Impedance strike, rotation, and tipper strike for Line 2, sites 10 to 13. 


\section{U.S. Geological Survey}

Denver Federal Center

Denver, Colorado 80225

MT Data for: L2

Date: 09/19/08
F Geotools

MT Workstation

by

Geotools Corporation

5808 Balcones Dr. Suite 202

Austin, Texas 78731 USA

(512) 454-0679
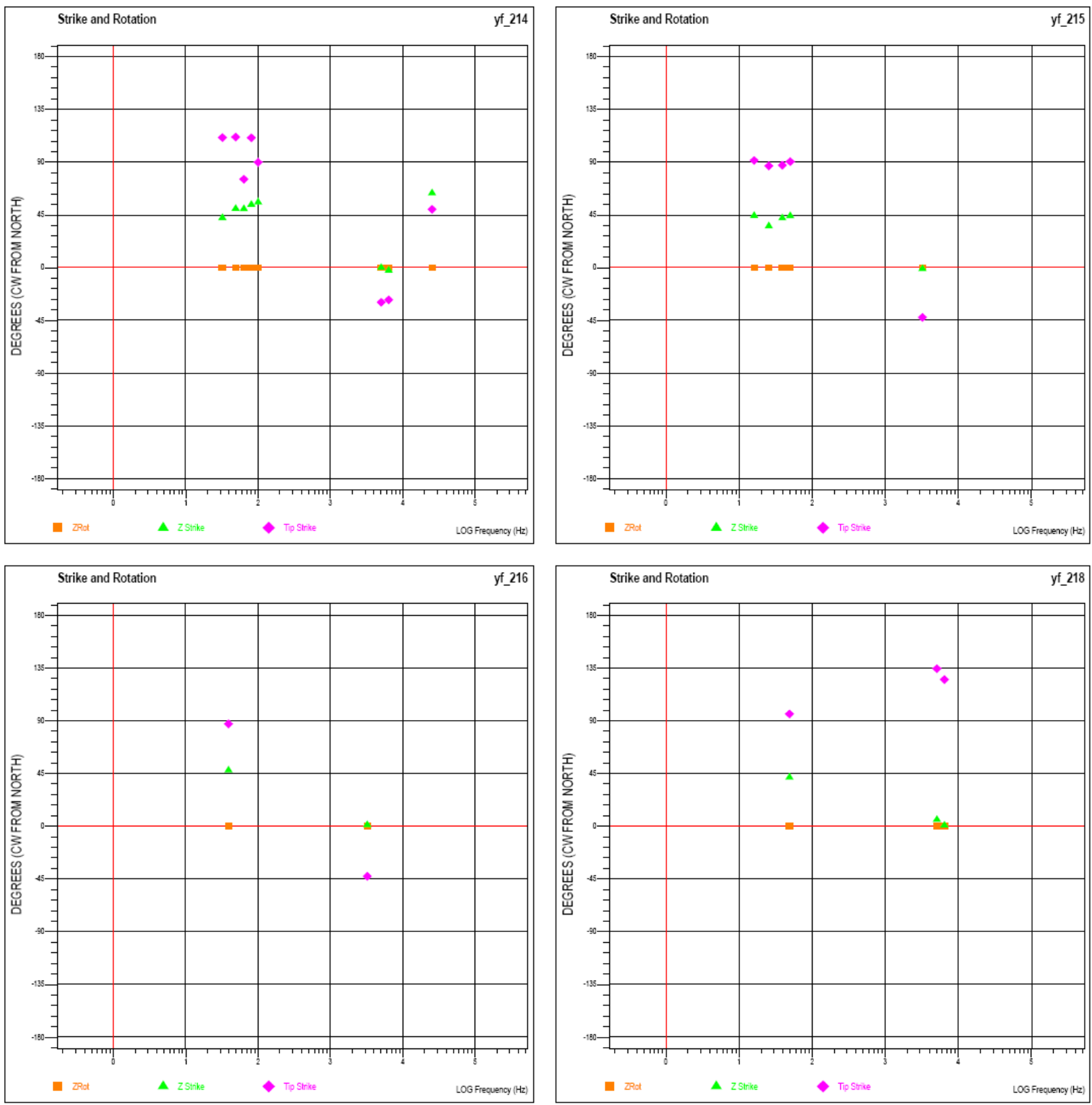

Figure B-91. Impedance strike, rotation, and tipper strike for Line 2, sites 14 to 18. 


\section{U.S. Geological Survey}

Denver Federal Center

Denver, Colorado 80225

MT Data for: L2

Date: 09/19/08
拝Geotools

by

Geotools Corporation

5808 Balcones Dr. Suite 202

Austin, Texas 78731 USA

(512) 454-0679
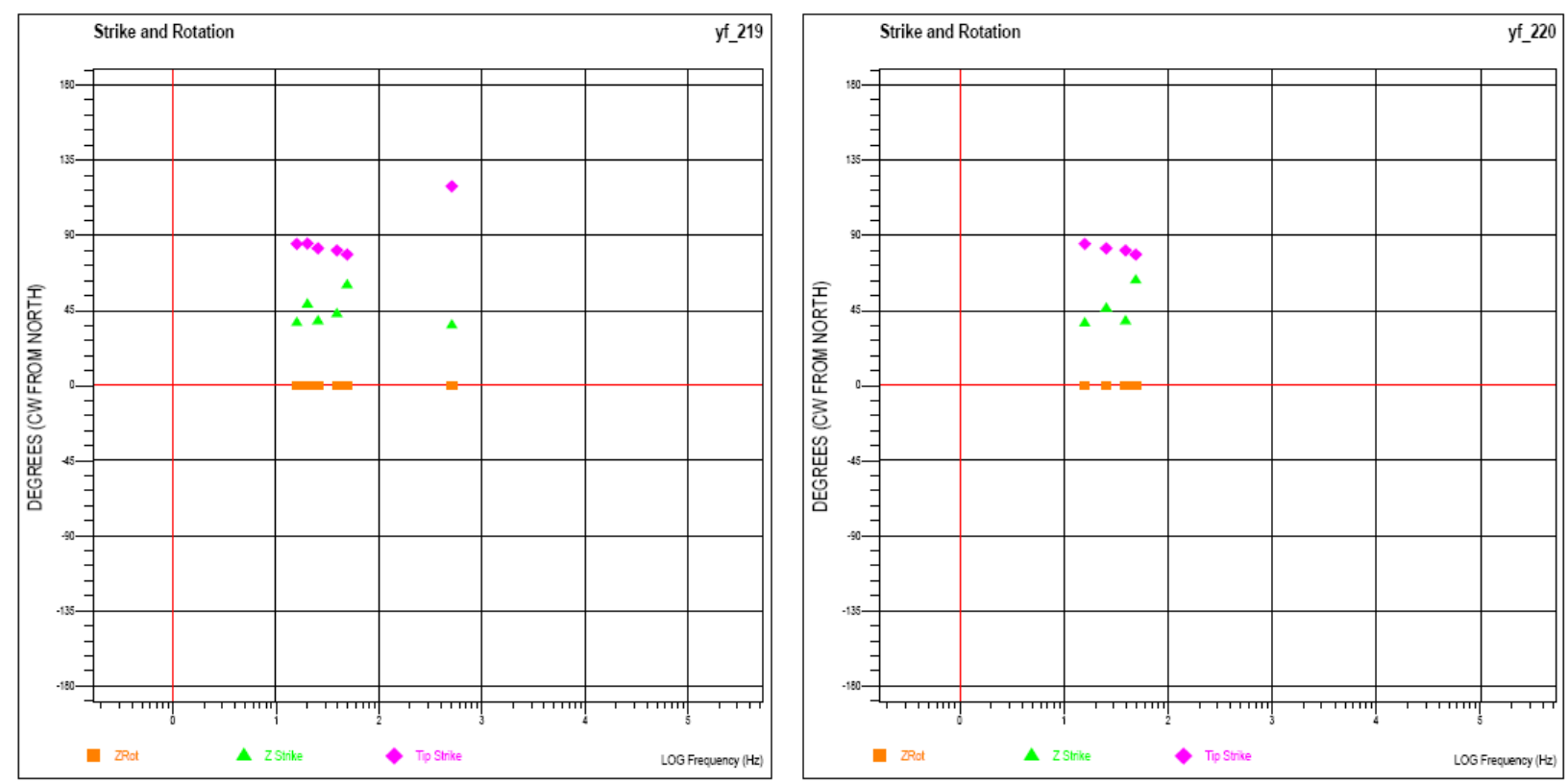

Figure B-92. Impedance strike, rotation, and tipper strike for Line 2, sites 19 to 20. 


\section{U.S. Geological Survey}

Denver Federal Center

Denver, Colorado 80225

MT Data for: L3

Date: 09/23/08

\section{平Geotools \\ MT Workstation}

by

Geotools Corporation

5808 Balcones Dr. Sulte 202

Austin, Texas 78731 USA

(512) $454-0679$

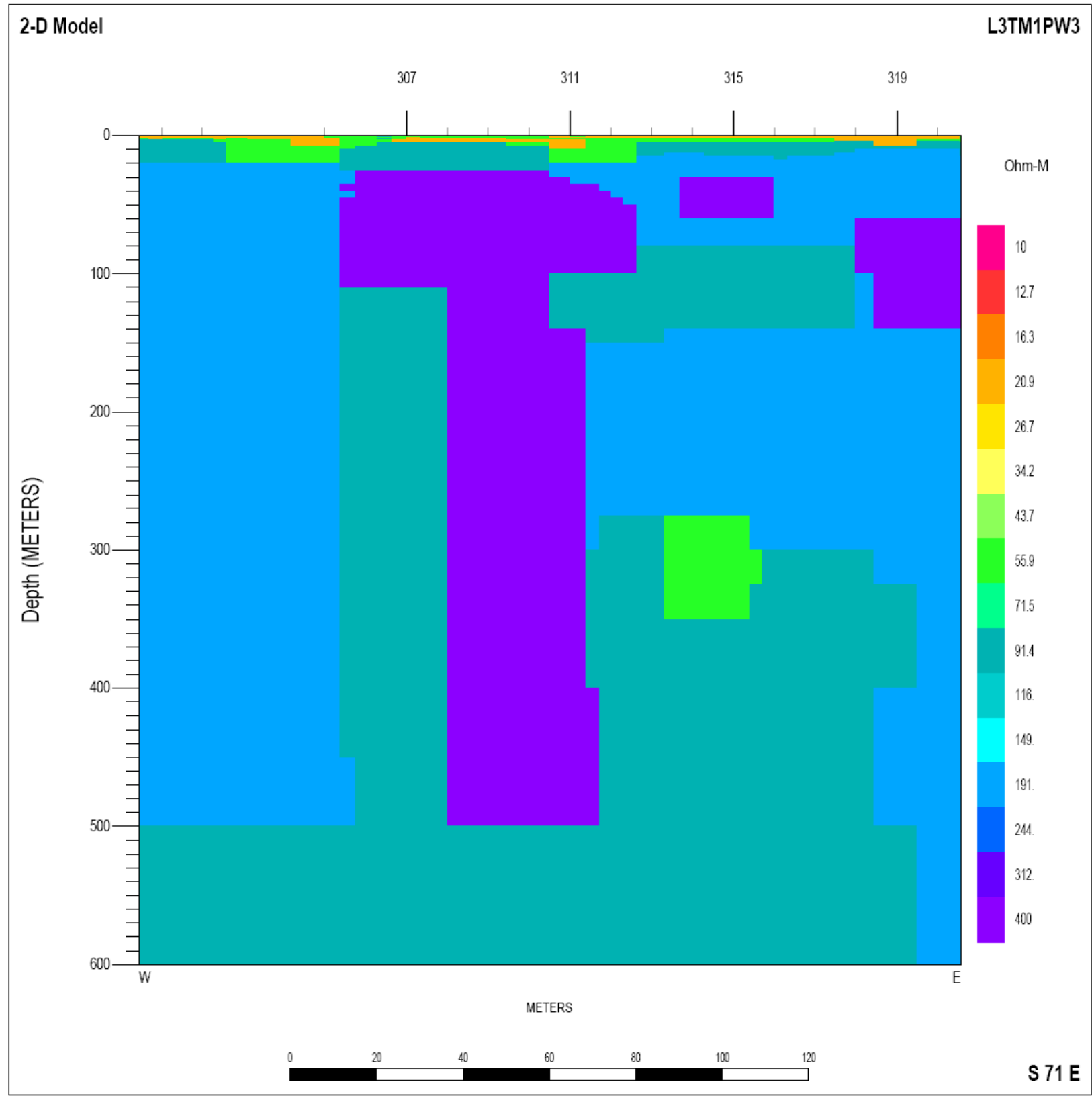

Figure B-93. Two-dimensional inversion model for Line 3 without the finite difference mesh. 


\section{U.S. Geological Survey}

Denver Federal Center

Denver, Colorado 80225

MT Data for: L3

Date: 09/23/08

\section{垂Geotools \\ MT Workstation}

by

Geotools Corporation

5808 Balcones Dr. Sulte 202

Austin, Texas 78731 USA

(512) $454-0679$

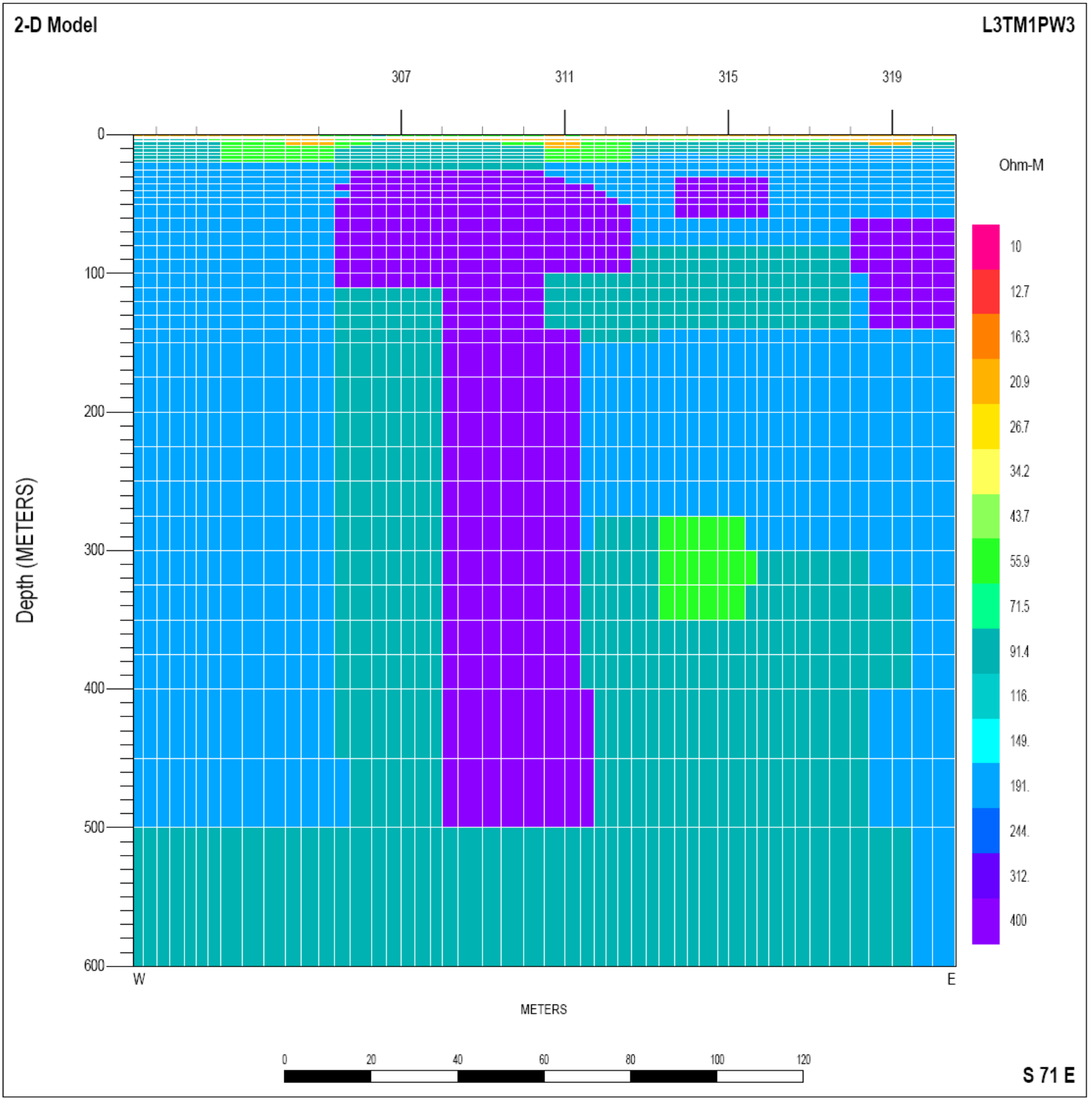

Figure B-94. Two-dimensional inversion model for Line 3 with the finite difference mesh. 


\section{U.S. Geological Survey}

Denver Federal Center

Denver, Colorado 80225

MT Data for: L3

拝Geotools

MT Workstation

by

Geotools Corporation

5808 Balcones Dr. Sute 202

Date: 09/18/08

Austin, Texas 78731 USA

(512) $454-0679$
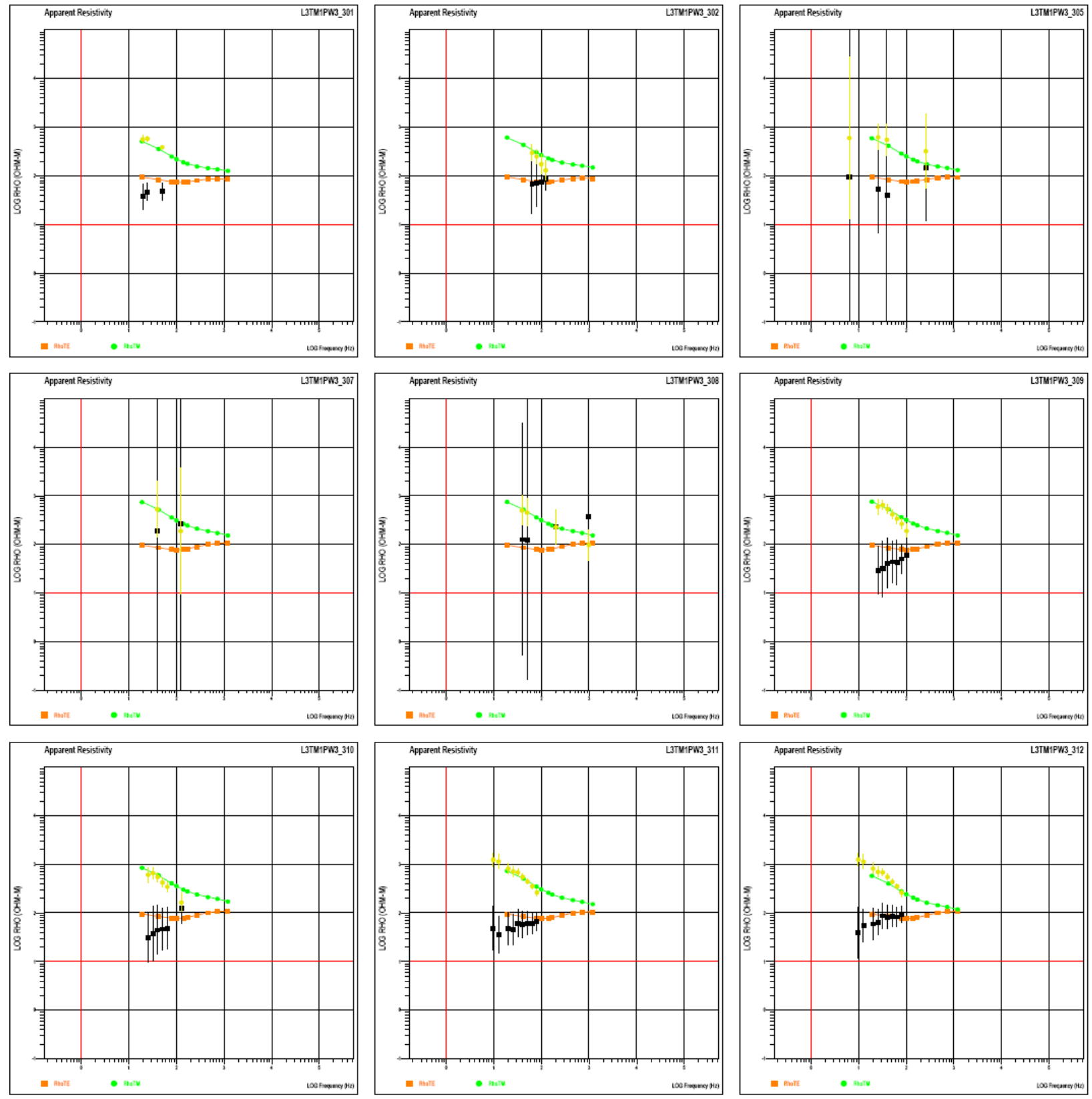

Figure B-95. Apparent resistivity data for Line 3, sites 1 to 12. 


\section{U.S. Geological Survey}

Denver Federal Center

Denver, Colorado 80225

MT Data for: L3

拝Geotools

MT Workstation

by

Geotools Corporation

5808 Balcones Dr. Suite 202

Date: $09 / 18 / 08$
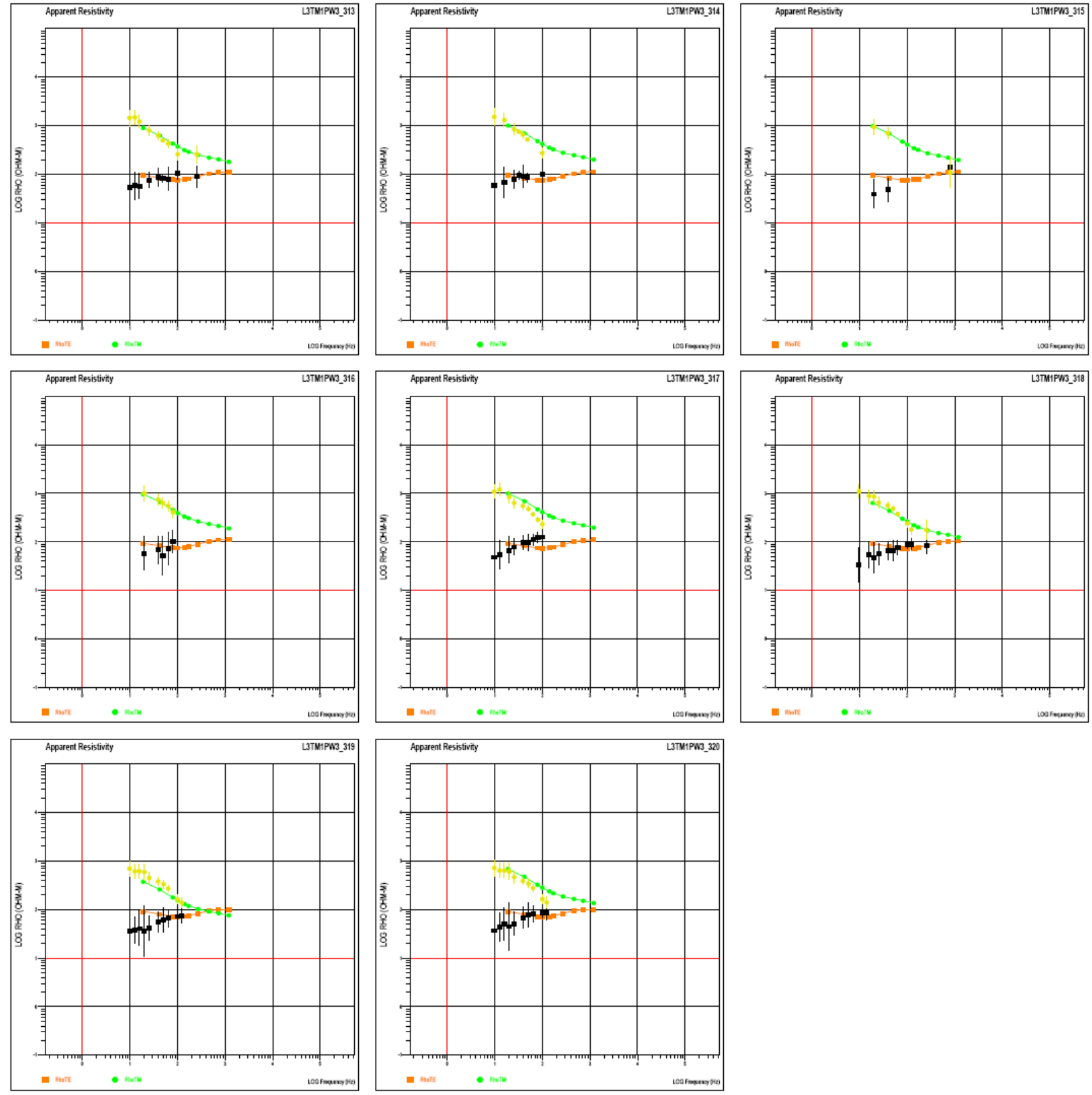

Figure B-96. Apparent resistivity data for Line 3, sites 13 to 20 . 


\title{
U.S. Geological Survey
}

\author{
Denver Federal Center \\ Denver, Colorado 80225 \\ MT Data for: L3 \\ Date: $09 / 18 / 08$
}

MT Workstation

by

Geotools Corporation

5808 Balcones Dr. Sute 202

Austin, Texas 78731 USA

(512) 454.0679
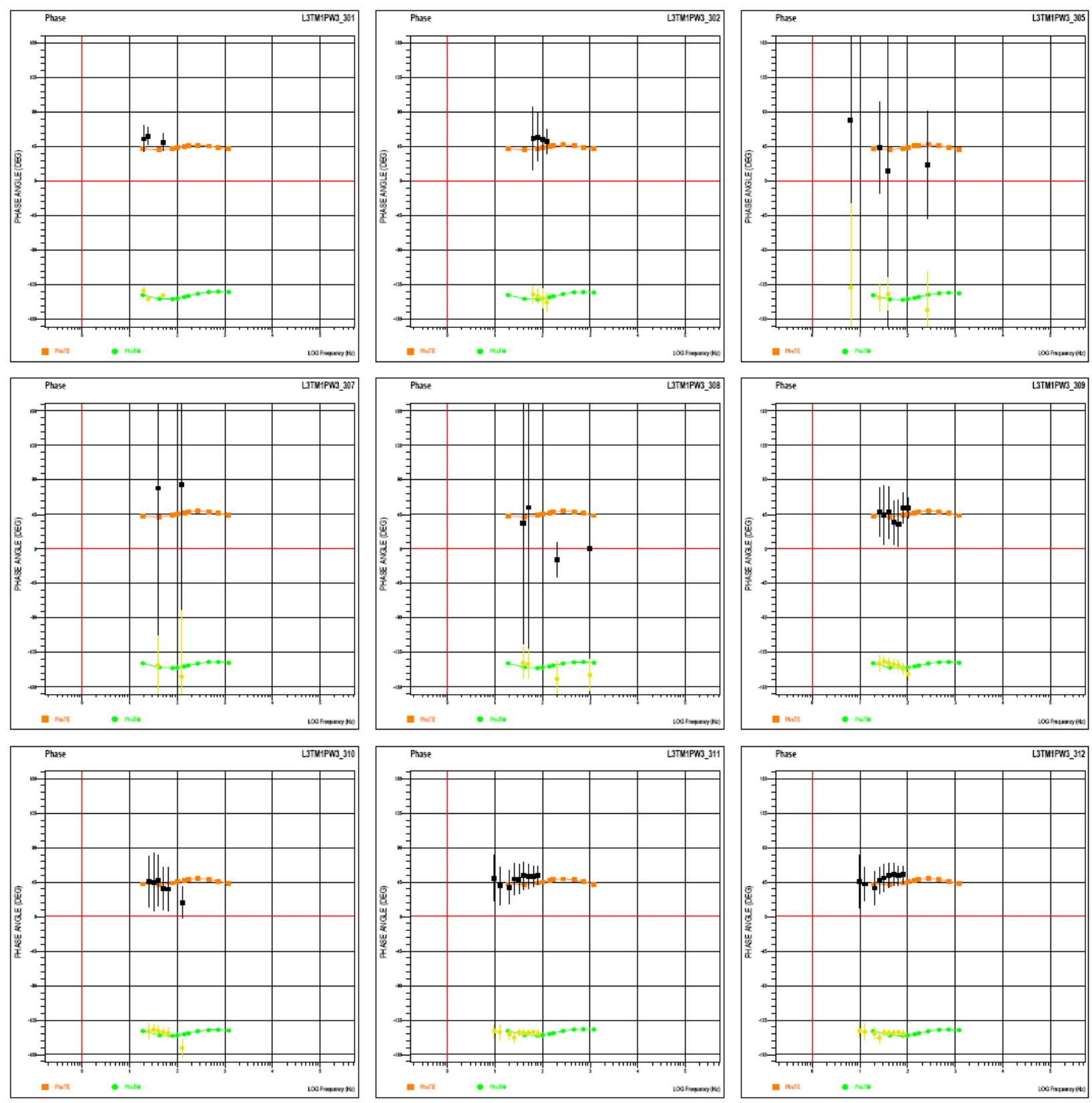

Figure B-97. Phase data for Line 3, sites 1 to 12. 


\title{
U.S. Geological Survey
}

\author{
Denver Federal Center \\ Denver, Colorado 80225 \\ MT Data for: L3 \\ Date: 09/18/08
}
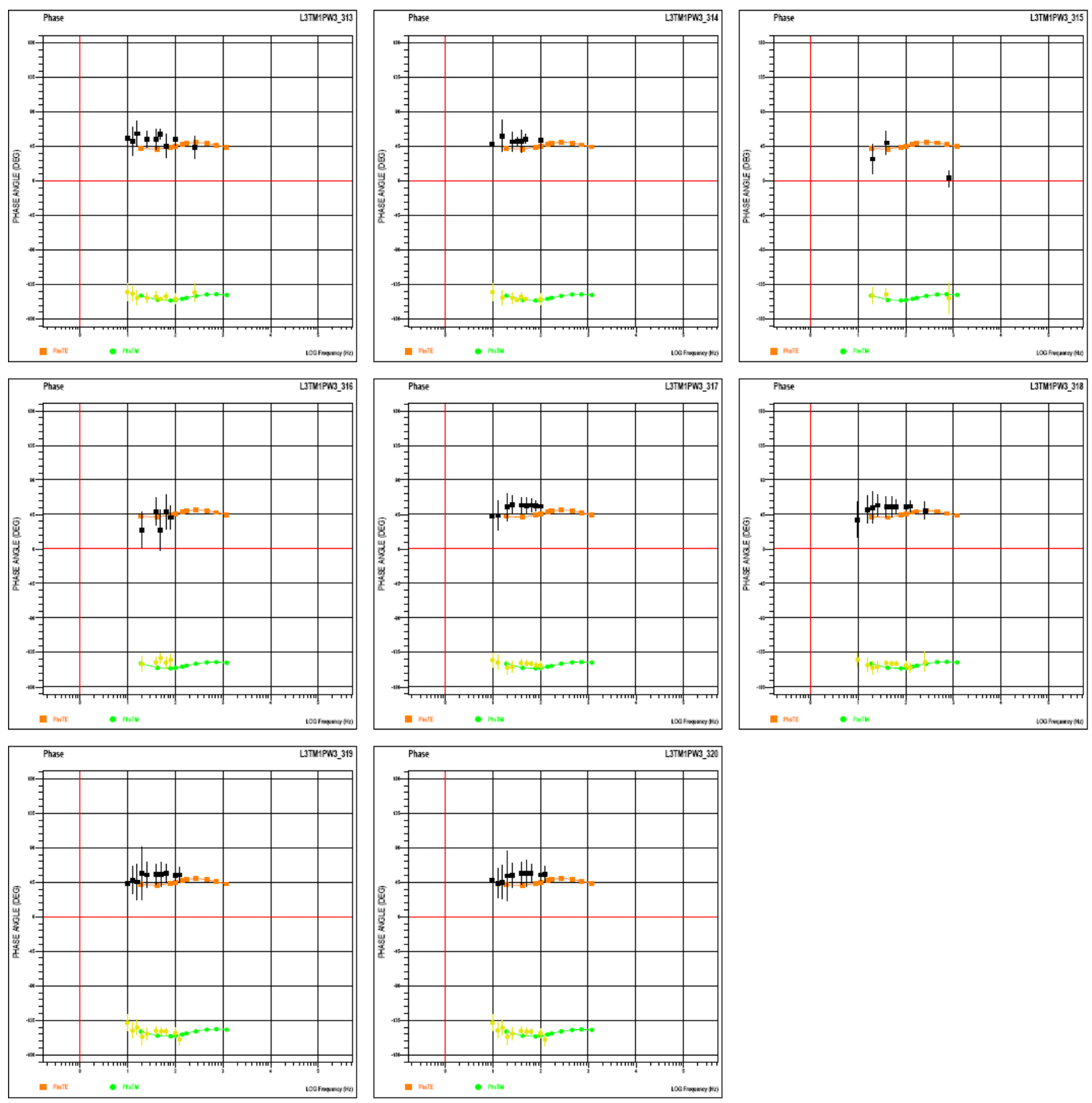

Figure B-98. Phase data for Line 3, sites 13 to 20. 


\section{U.S. Geological Survey}

Denver Federal Center

Denver, Colorado 80225

MT Data for: L3

Date: 09/19/08
\#Geotools

MT Workstation

by

Geotools Corporation

5808 Balcones Dr. Suite 202

Austin, Texas 78731 USA

(512) 454-0679
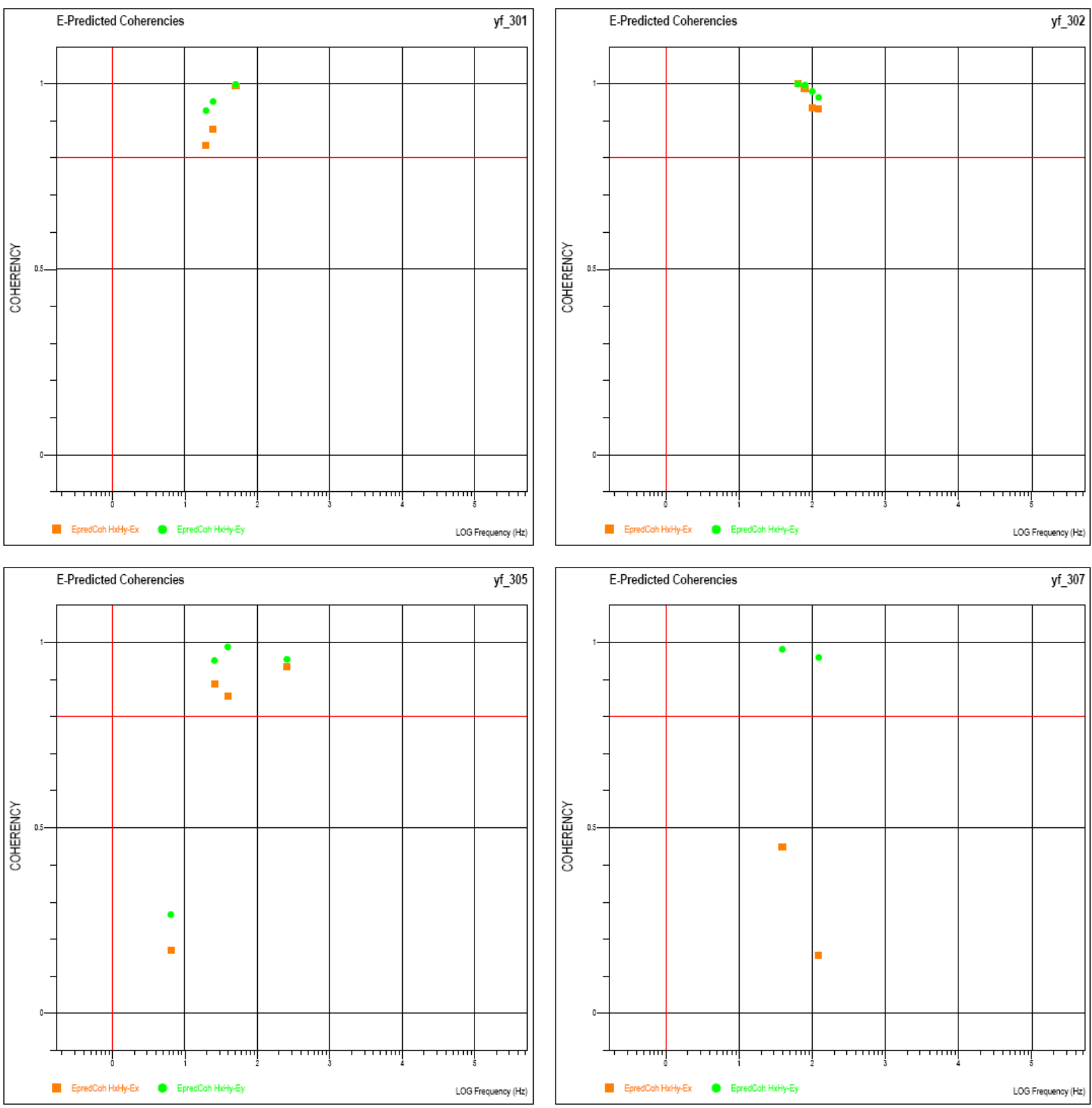

Figure B-99. E-predicted coherencies for Line 3, sites 1 to 7. 


\section{U.S. Geological Survey}

Denver Federal Center

Denver, Colorado 80225

MT Data for: L3

Date: 09/19/08

拝Geotools

MT Workstation

by

Geotools Corporation

5808 Balcones Dr. Suite 202

Austin, Texas 78731 USA

(512) 454-0679
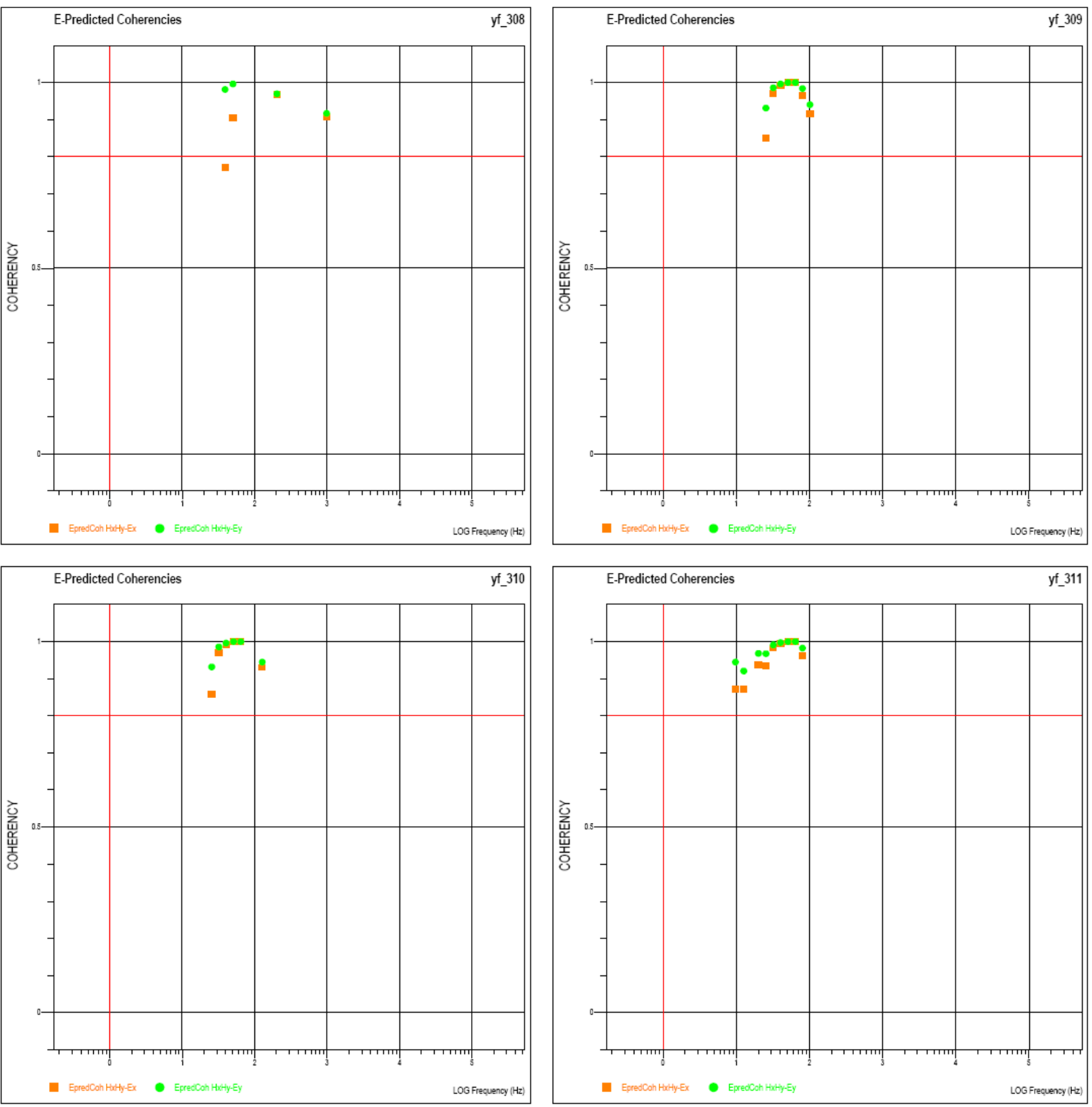

Figure B-100. E-predicted coherencies for Line 3, sites 8 to 11. 


\section{U.S. Geological Survey}

Denver Federal Center

Denver, Colorado 80225

MT Data for: L3

Date: 09/19/08
Feotools

MT Workstation

by

Geotools Corporation

5808 Balcones Dr. Suite 202

Austin, Texas 78731 USA

(512) 454-0679
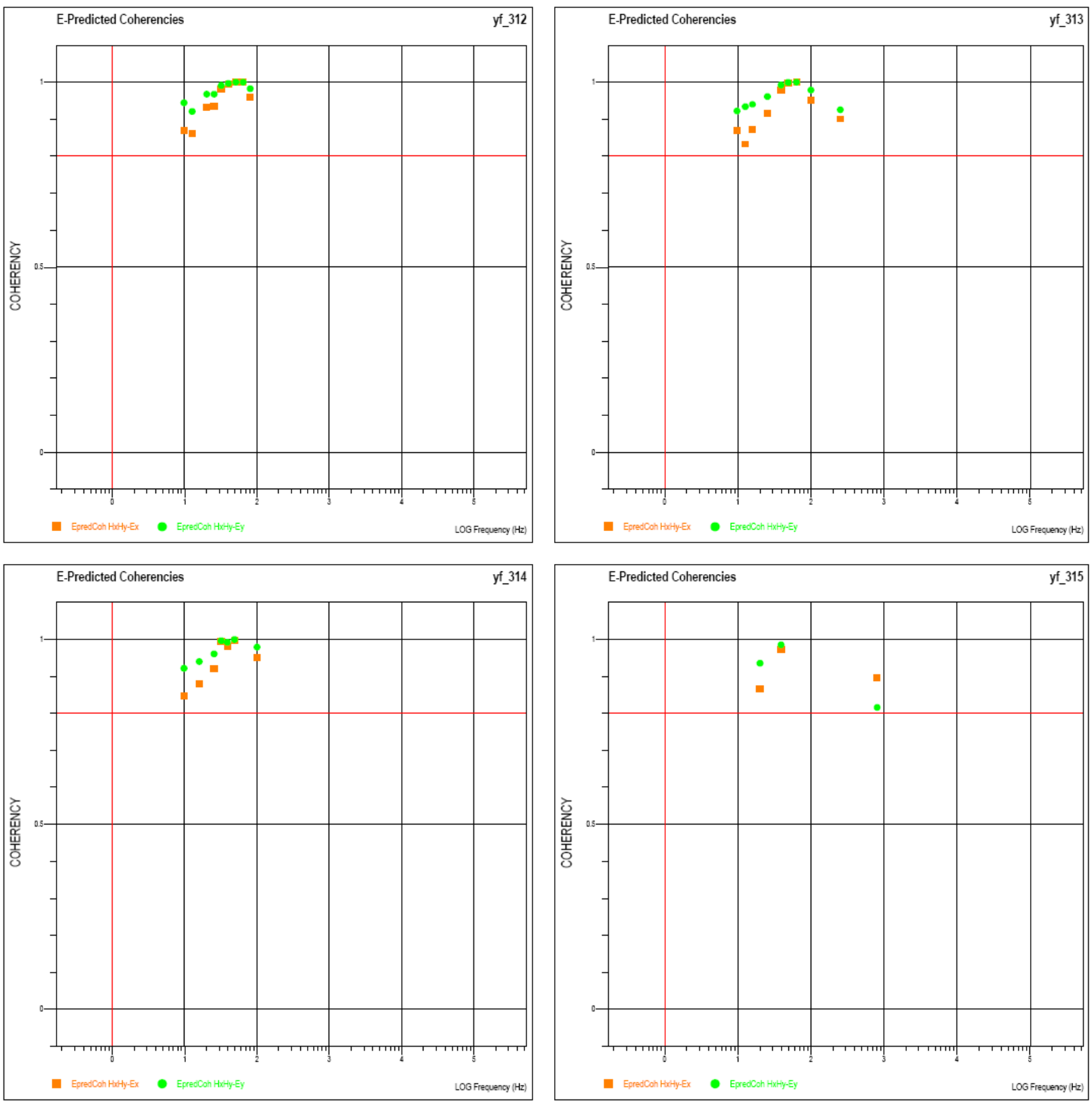

Figure B-101. E-predicted coherencies for Line 3, sites 12 to 15. 

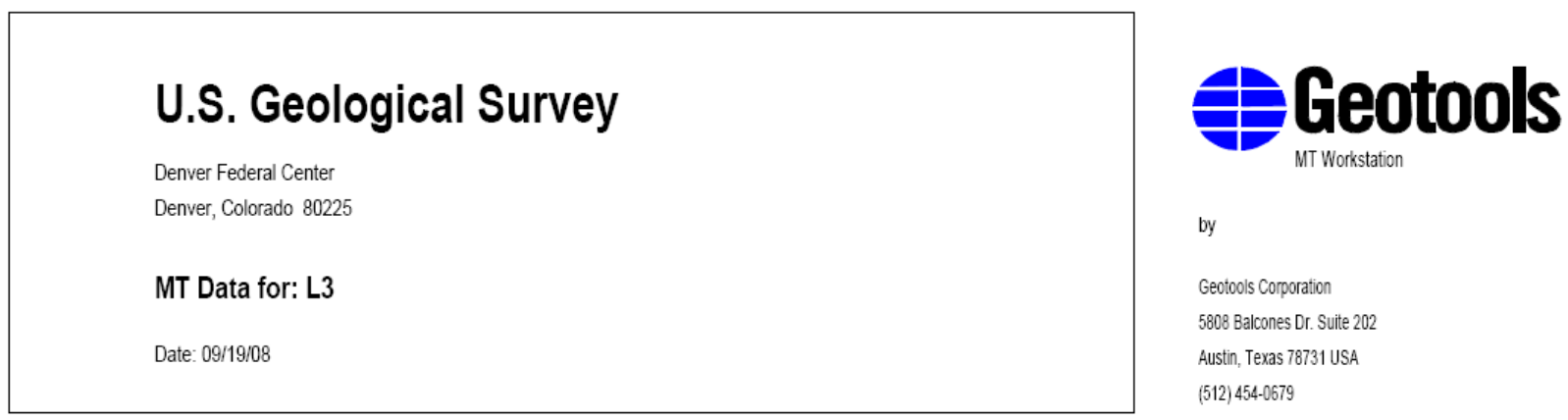

by

Geotools Corporation

5808 Balcones Dr. Suite 202

Austin, Texas 78731 USA

(512) $454-0679$
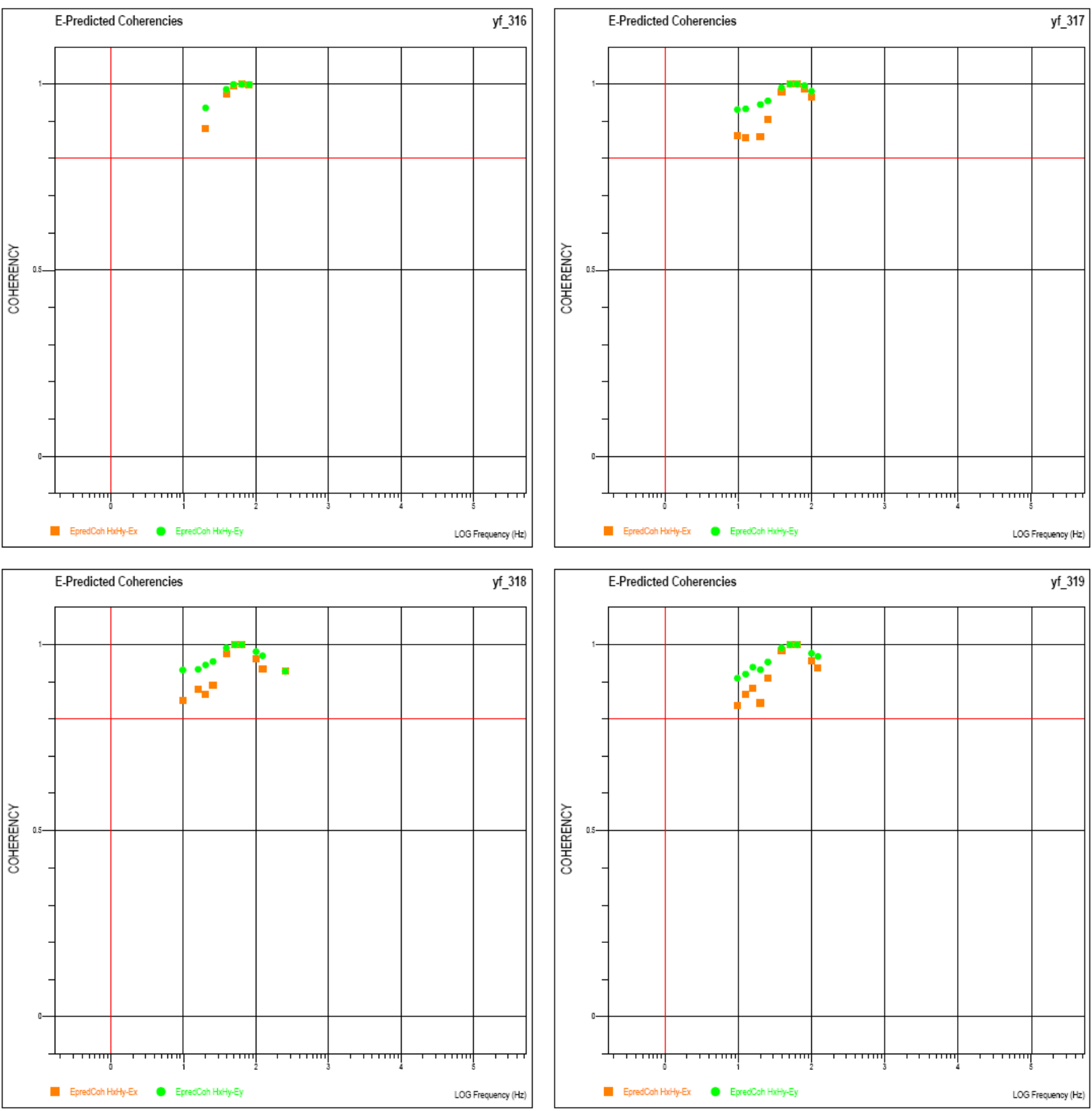

Figure B-102. E-predicted coherencies for Line 3, sites 16 to 19. 

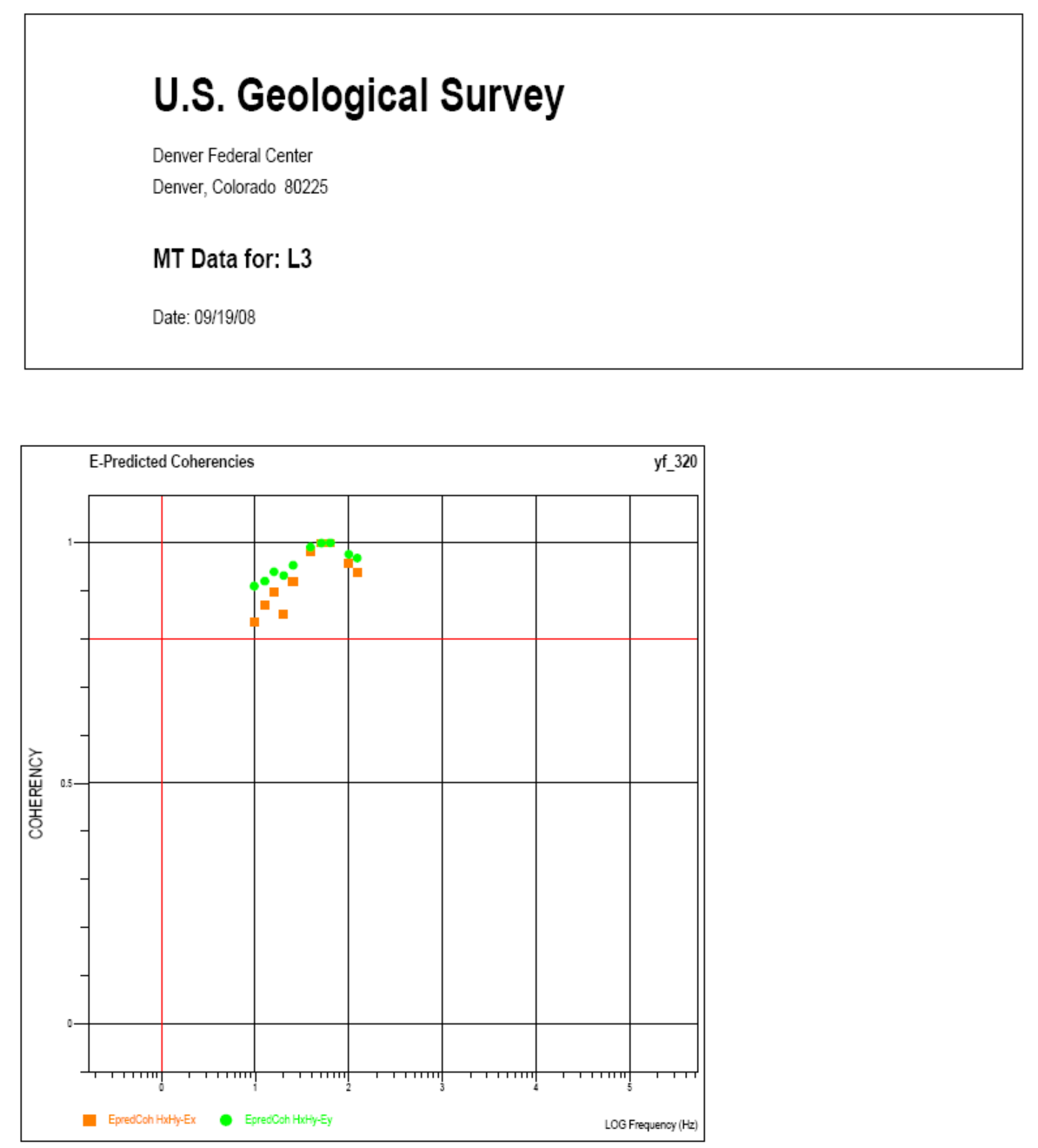

Figure B-103. E-predicted coherencies for Line 3, site 20.

\section{垂Geotools}

by

Geotools Corporation

5808 Balcones Dr. Suite 202

Austin, Texas 78731 USA

(512) $454-0679$ 


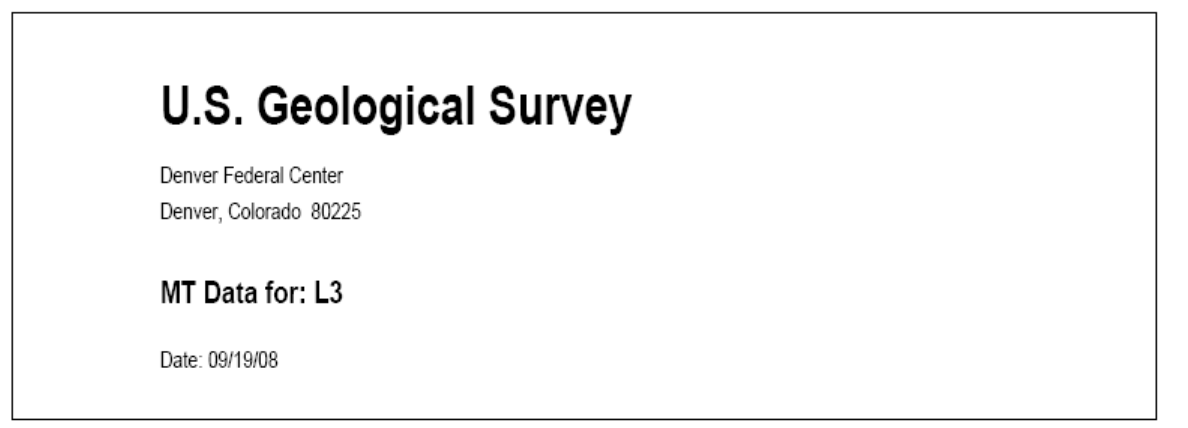

F Geotools

by

Geotools Corporation

5808 Balcones Dr. Suite 202

Austin, Texas 78731 USA

(512) $454-0679$
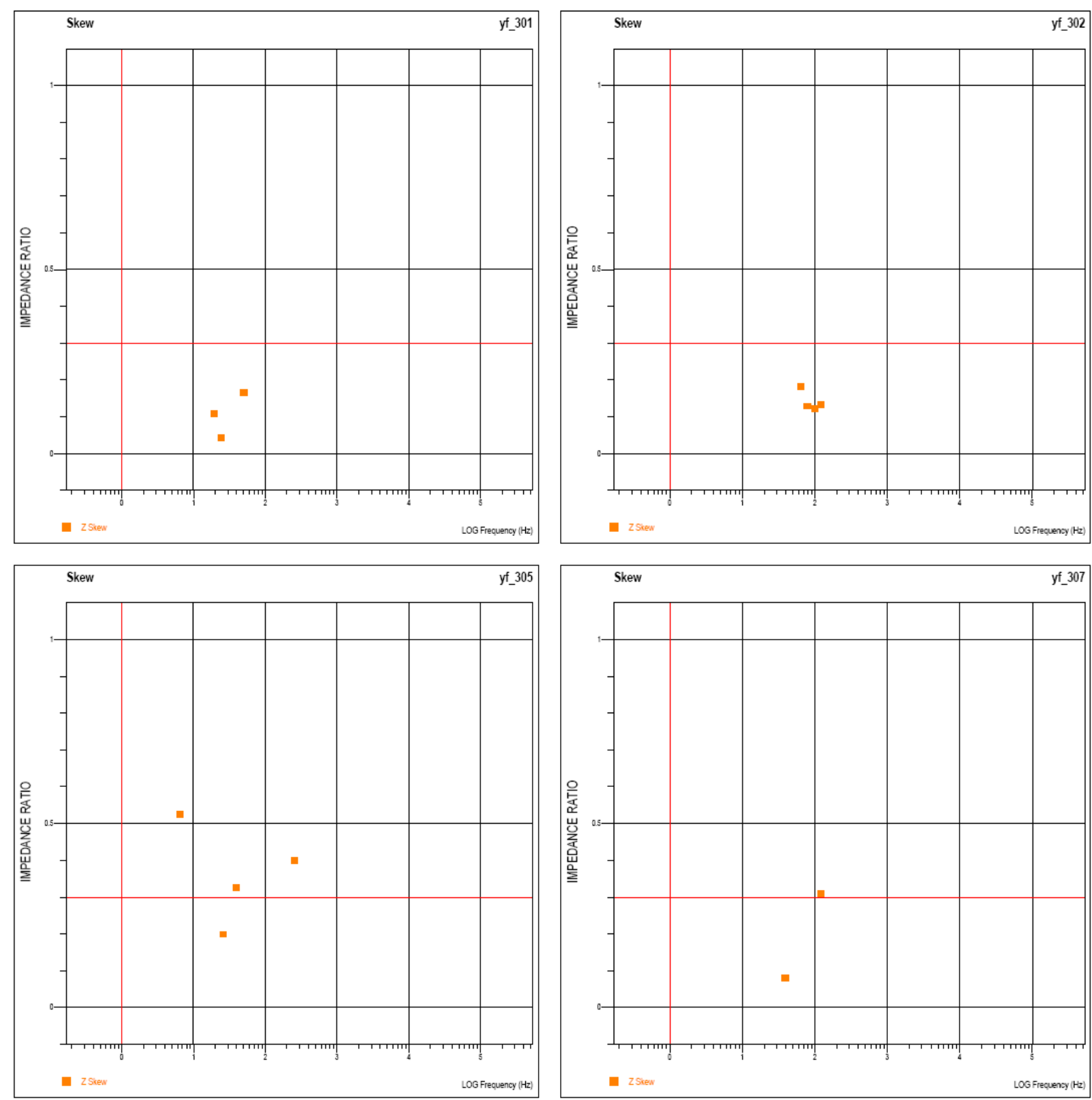

Figure B-104. Impedance skews for Line 3, sites 1 to 7. 


\section{U.S. Geological Survey}

Denver Federal Center

Denver, Colorado 80225

MT Data for: L3

Date: 09/19/08

F Geotools

by

Geotools Corporation

5808 Balcones Dr. Suite 202

Austin, Texas 78731 USA

(512) $454-0679$
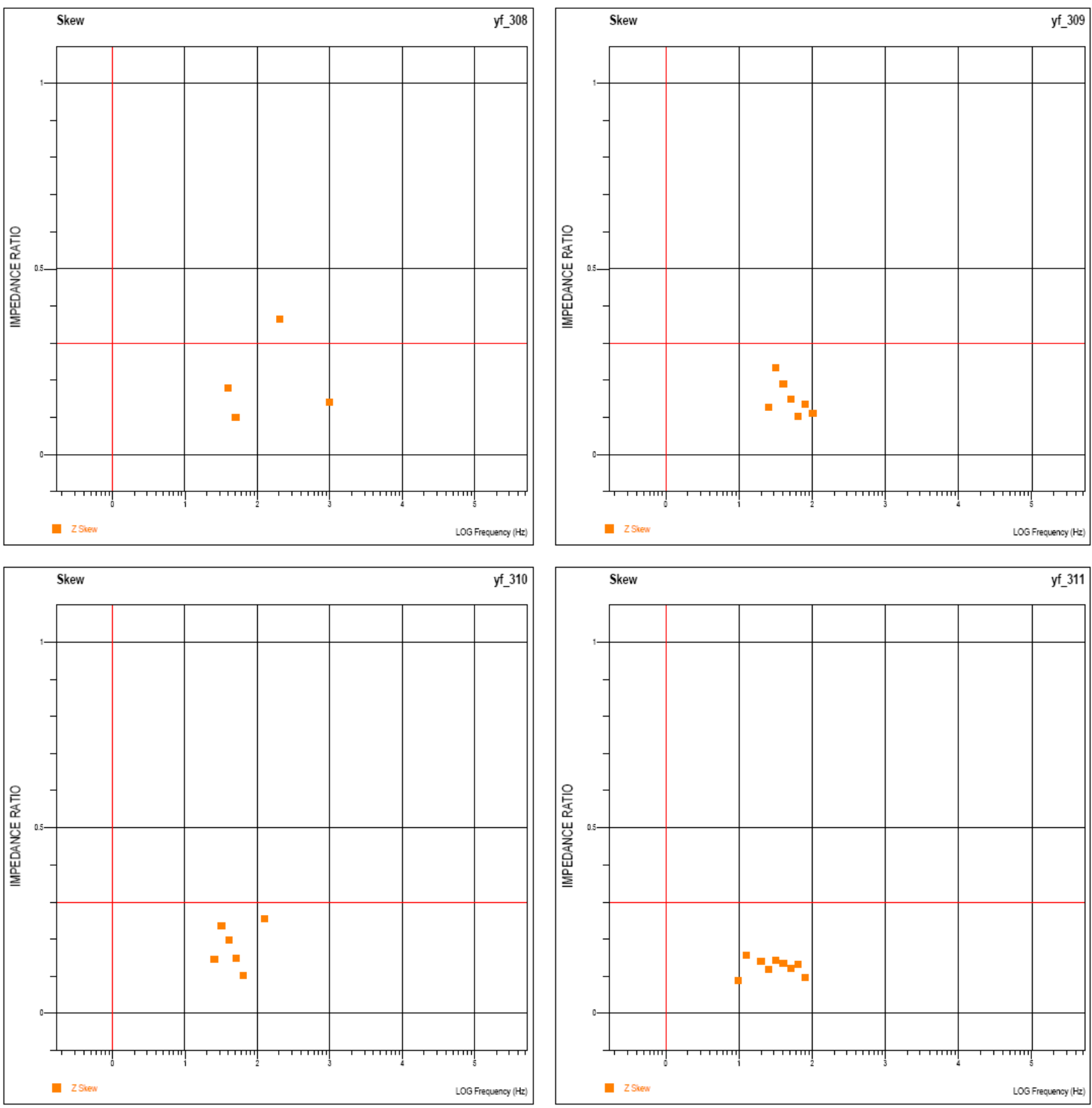

Figure B-105. Impedance skews for Line 3, sites 8 to 11 . 


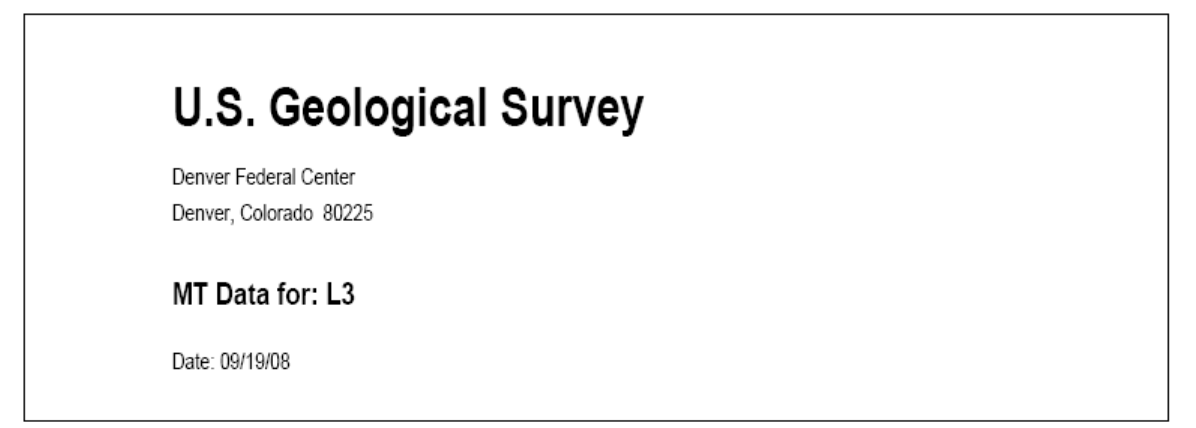

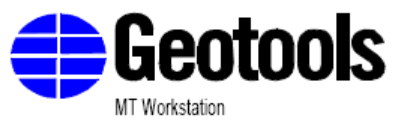

by

Geotools Corporation

5808 Balcones Dr. Suite 202

Austin, Texas 78731 USA

(512) $454-0679$
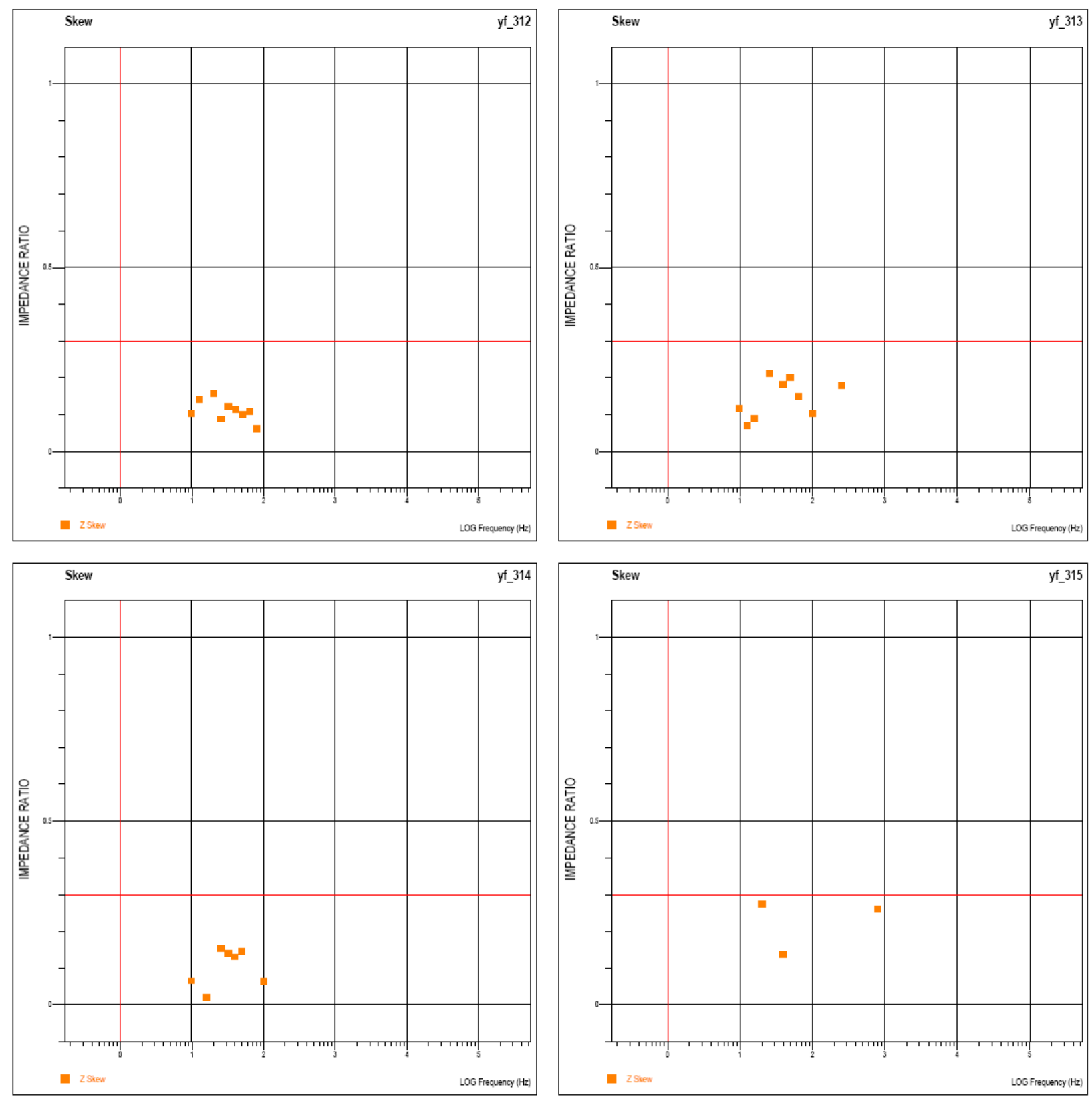

Figure B-106. Impedance skews for Line 3, sites 12 to 15. 


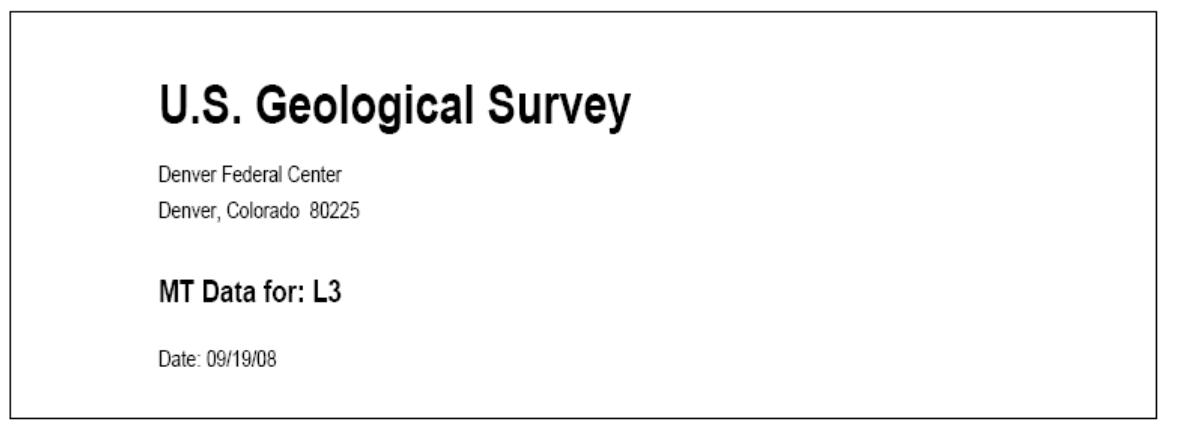

F Geotools

by

Geotools Corporation

5808 Balcones Dr. Suite 202

Austin, Texas 78731 USA

(512) 454-0679
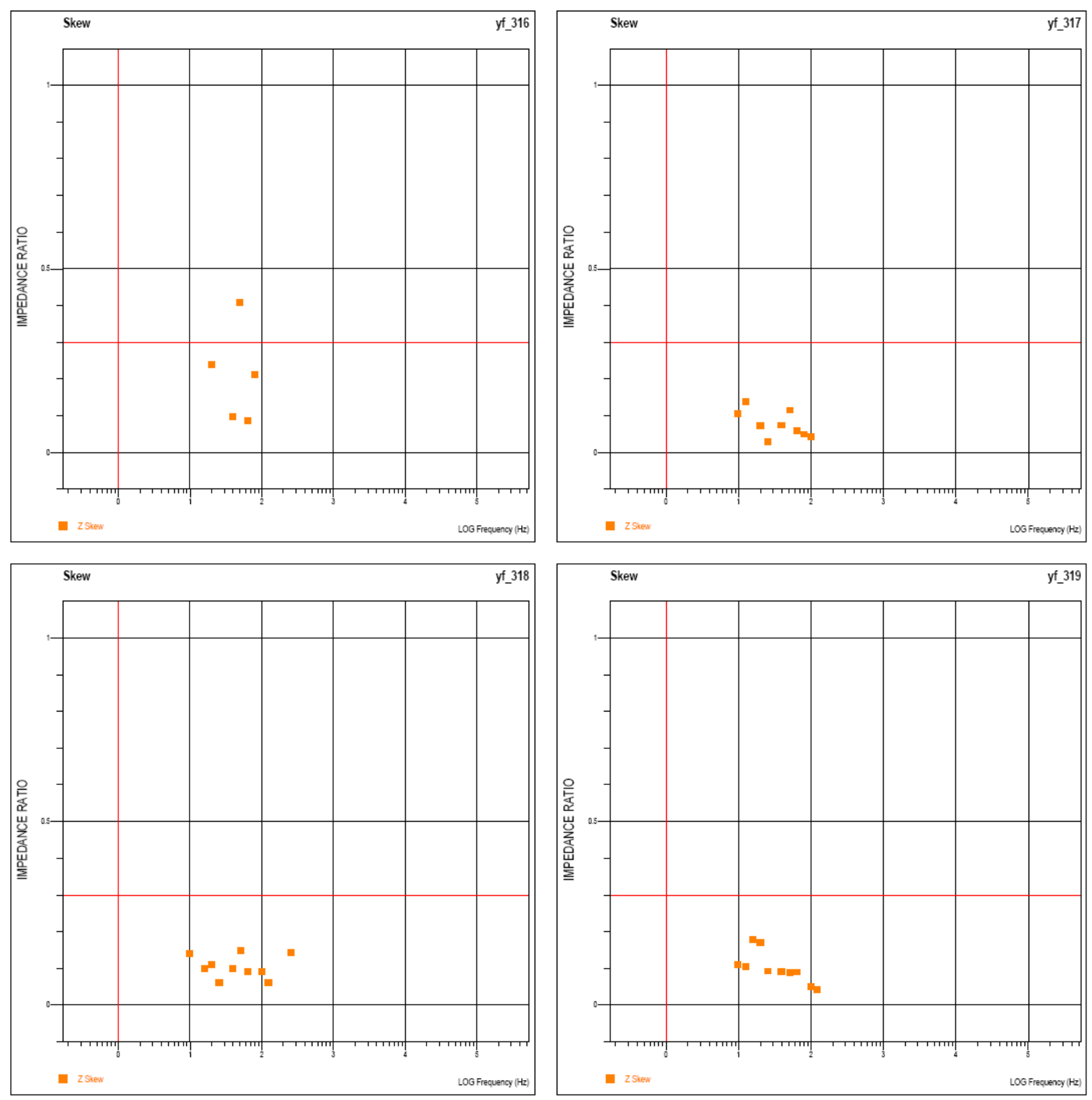

Figure B-107. Impedance skews for Line 3, sites 16 to 19. 

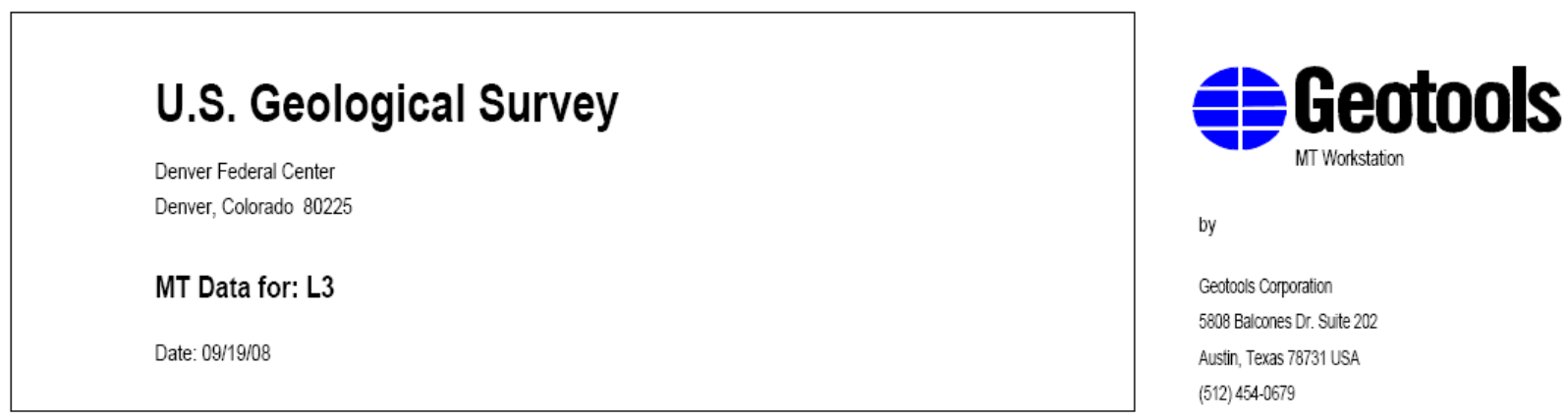

by

Geotools Corporation

5808 Balcones Dr. Sute 202

Ausini, Texas 78731 USA

(512) 454.0679

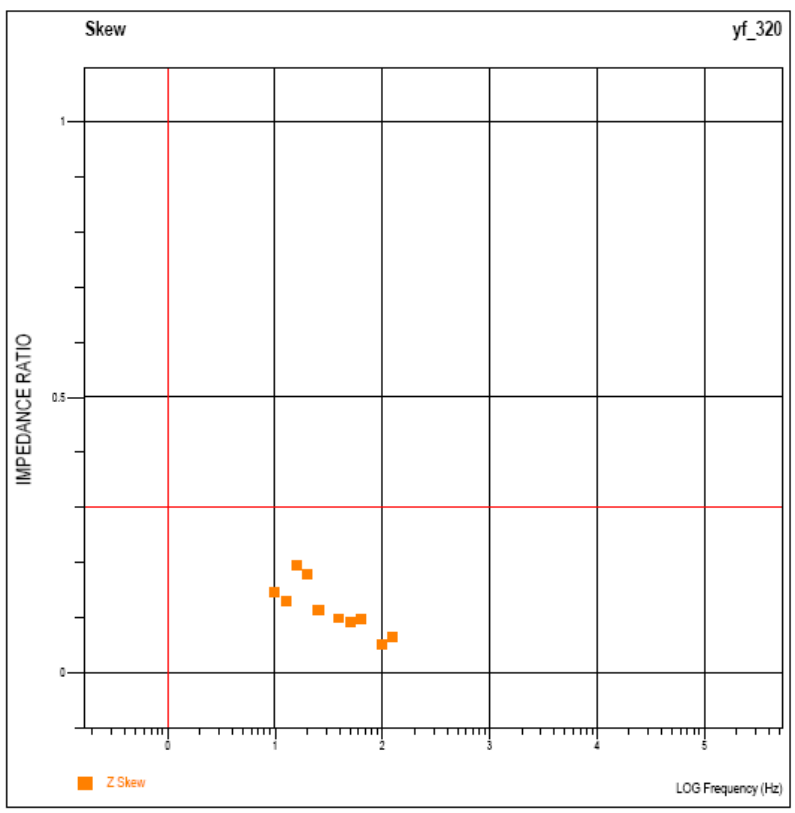

Figure B-108. Impedance skews for Line 3, site 20. 


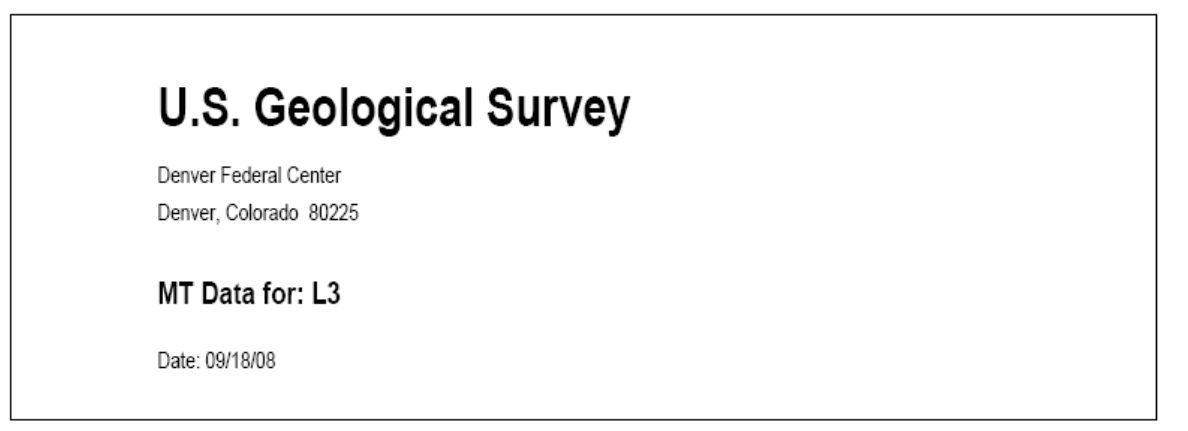

F Geotools

by

Geotools Corporation

5808 Balcones Dr. Suite 202

Austin, Texas 78731 USA

(512) 454-0679
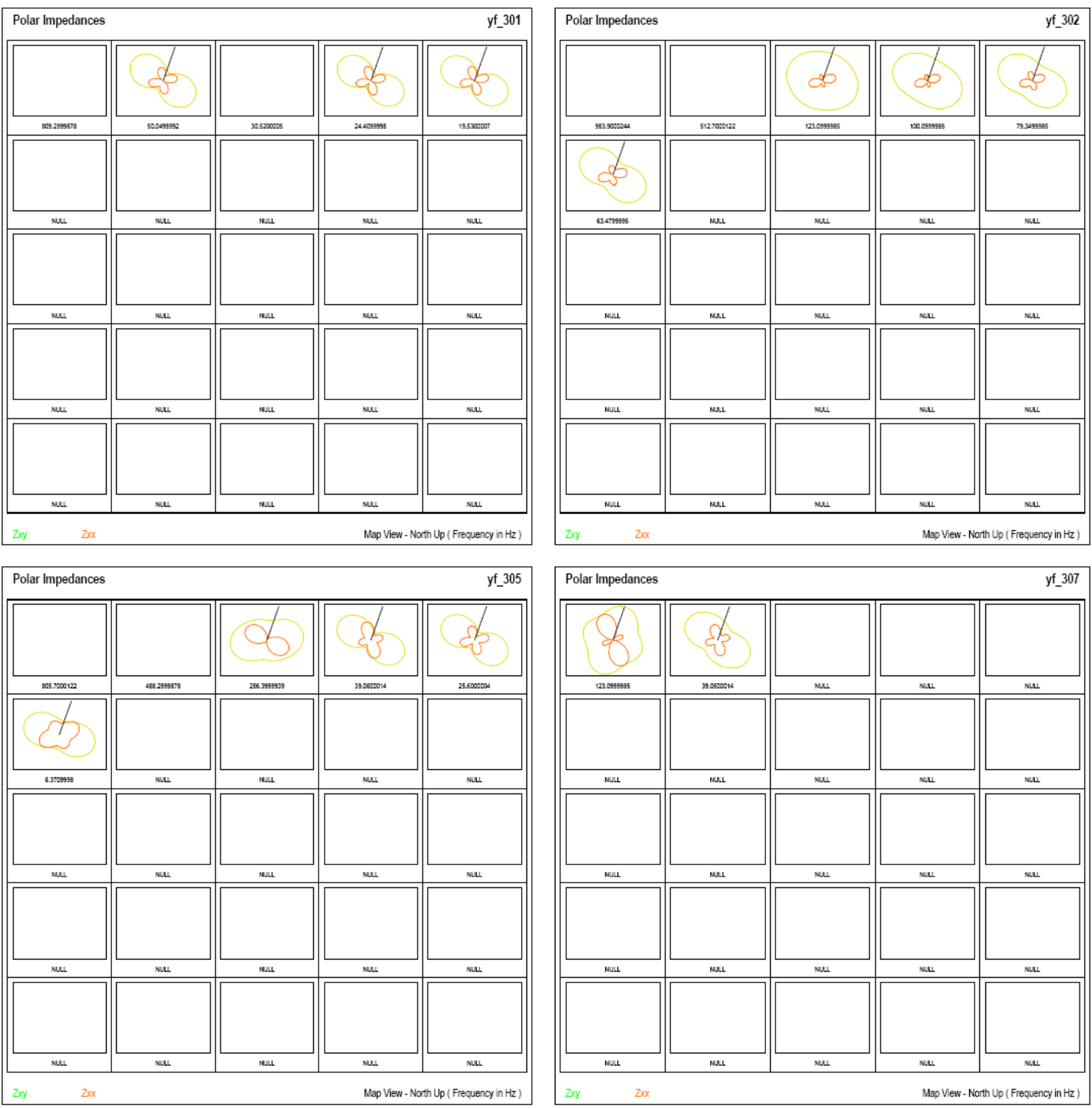

Figure B-109. Polar impedance plots for Line 3, sites 1 to 7. 


\section{U.S. Geological Survey}

Denver Federal Center

Denver, Colorado 80225

MT Data for: L3

Date: 09/18/08
F Geotools

MT Workstation

by

Geotools Corporation

5808 Balcones Dr. Suite 202

Austin, Texas 78731 USA

(512) 454-0679
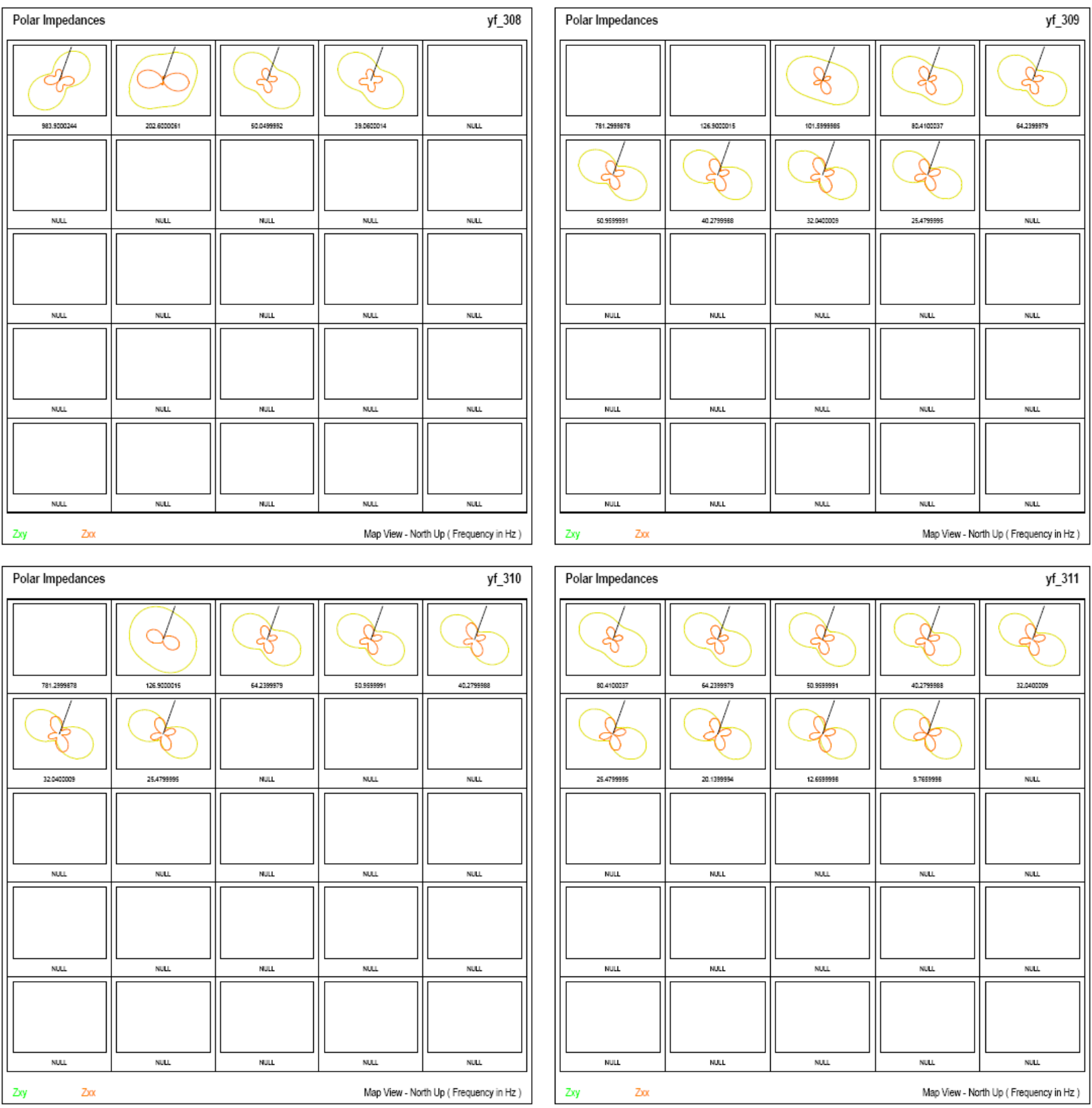

Figure B-110. Polar impedance plots for Line 3, sites 8 to 11. 


\section{U.S. Geological Survey}

Denver Federal Center

Denver, Colorado 80225

MT Data for: L3

Date: 09/18/08

Geotools Carporation 5808 Balcones Dr. Suite 202 Austin, Texas 78731 USA (512) 454-0679
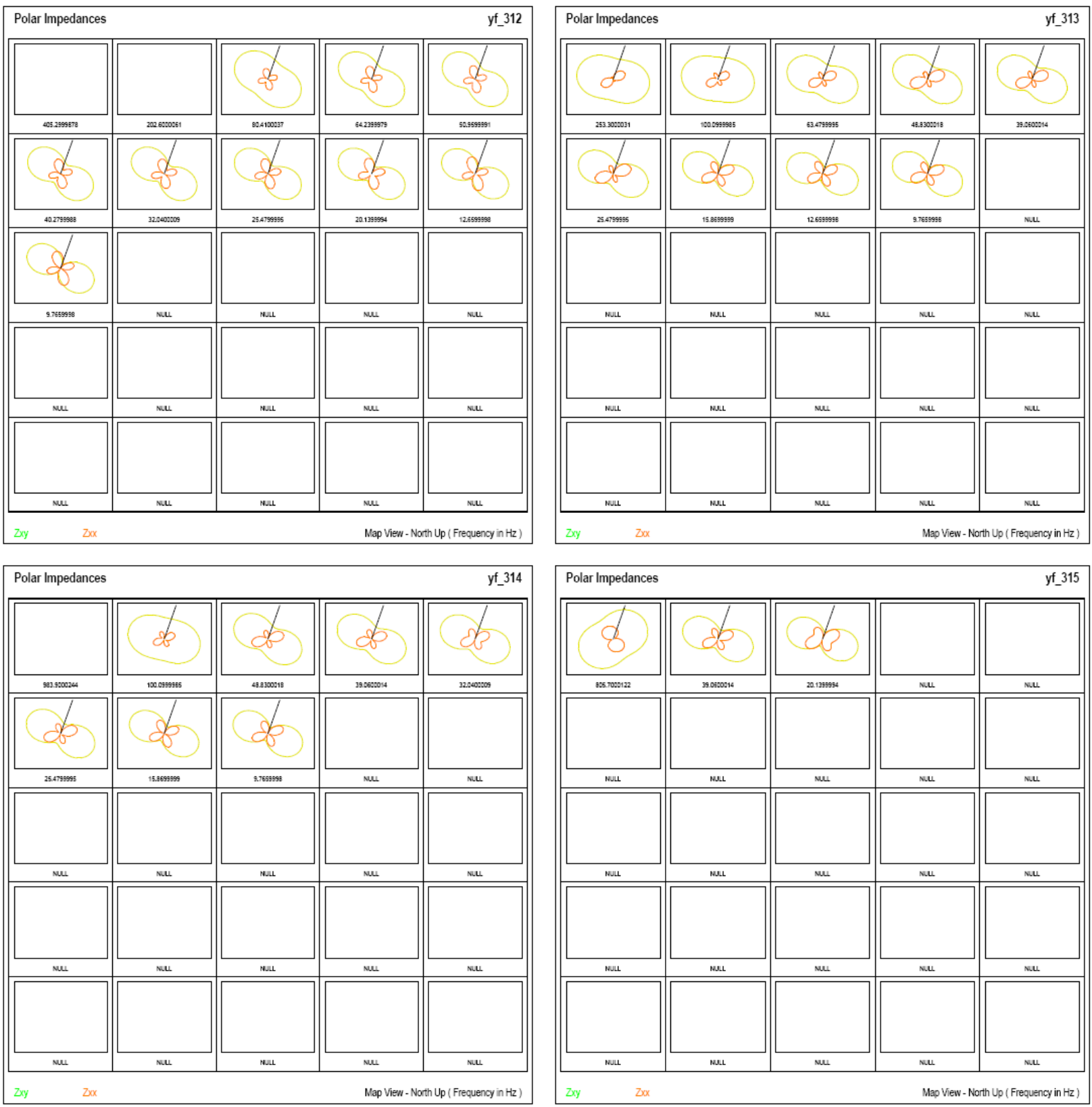

Figure B-111. Polar impedance plots for Line 3, sites 12 to 15. 


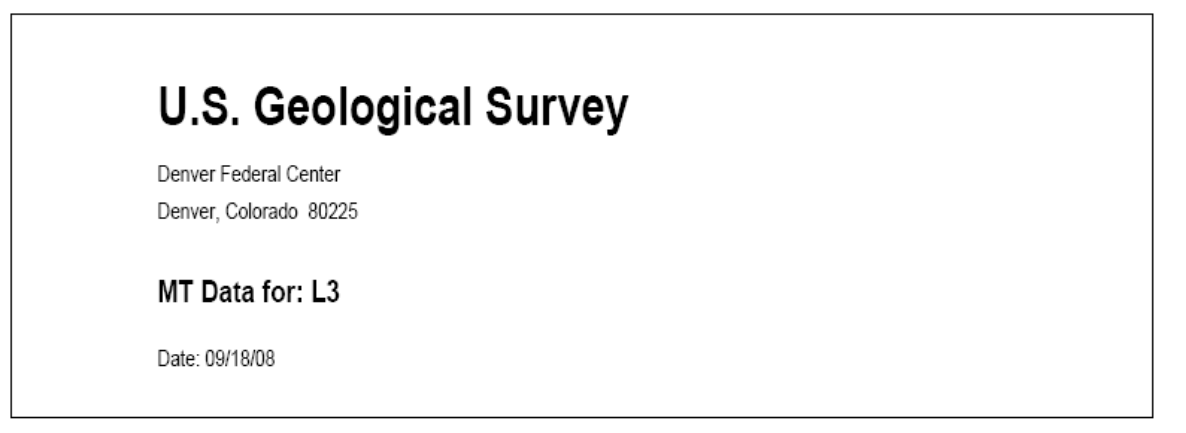

垂Geotools

by

Geotools Corporation

5808 Balcones Dr. Suite 202

Austin, Texas 78731 USA

(512) 454-0679
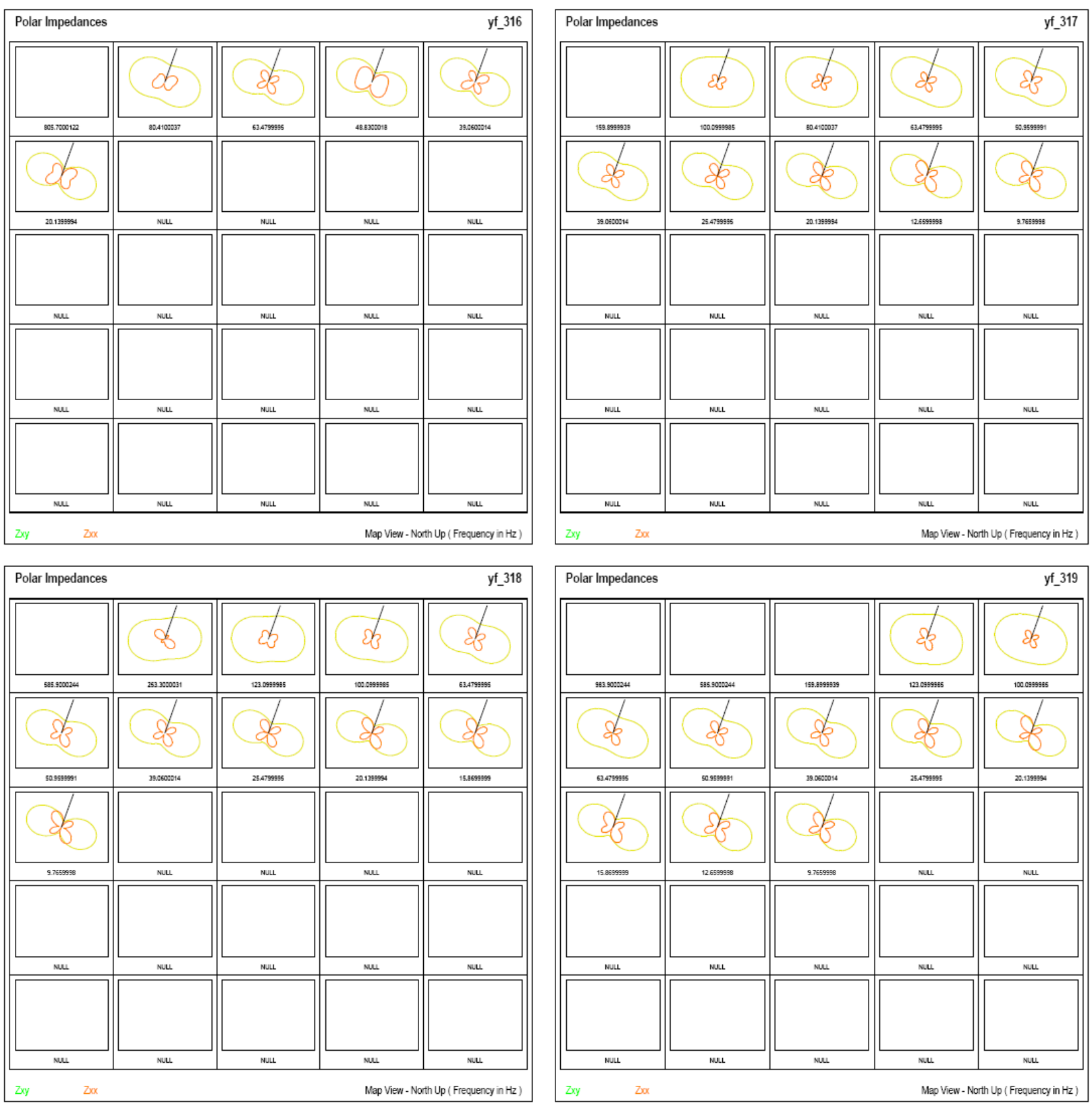

Figure B-112. Polar impedance plots for Line 3, sites 16 to 19. 


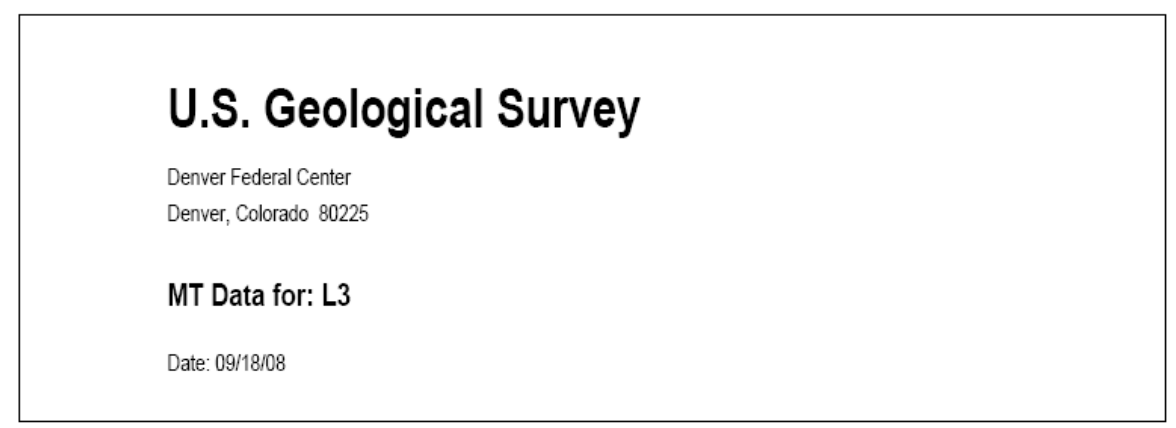

\section{平Geotools \\ MT Workstation}

by

Geotools Corporation

5808 Balcones Dr. Suite 202

Austin, Texas 78731 USA

(512) 454-0679

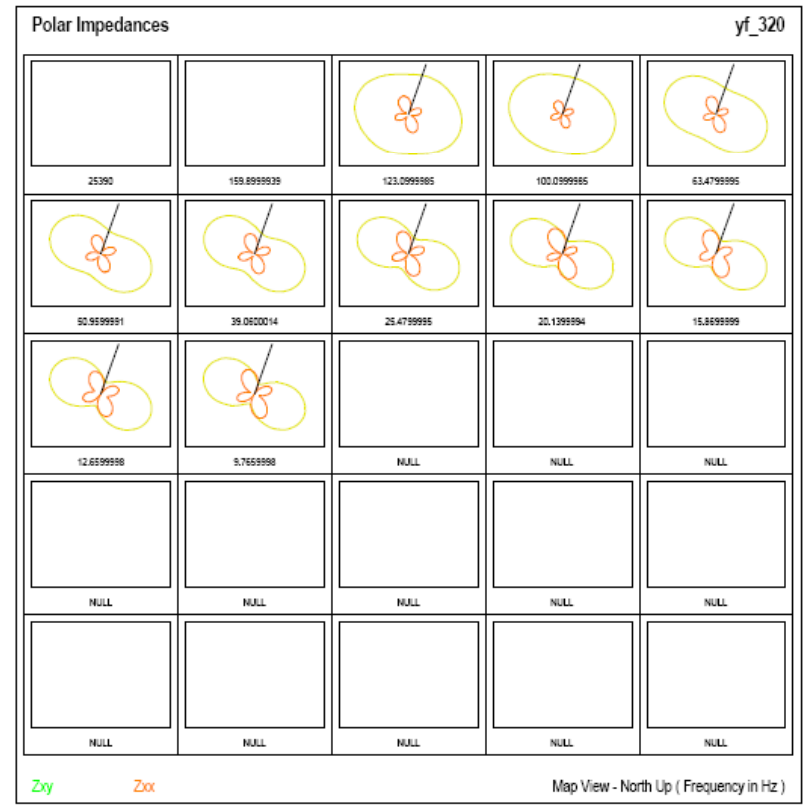

Figure B-113. Polar impedance plots for Line 3, site 20. 


\section{U.S. Geological Survey}

Denver Federal Center

Denver, Colorado 80225

MT Data for: L3

Date: 09/19/08
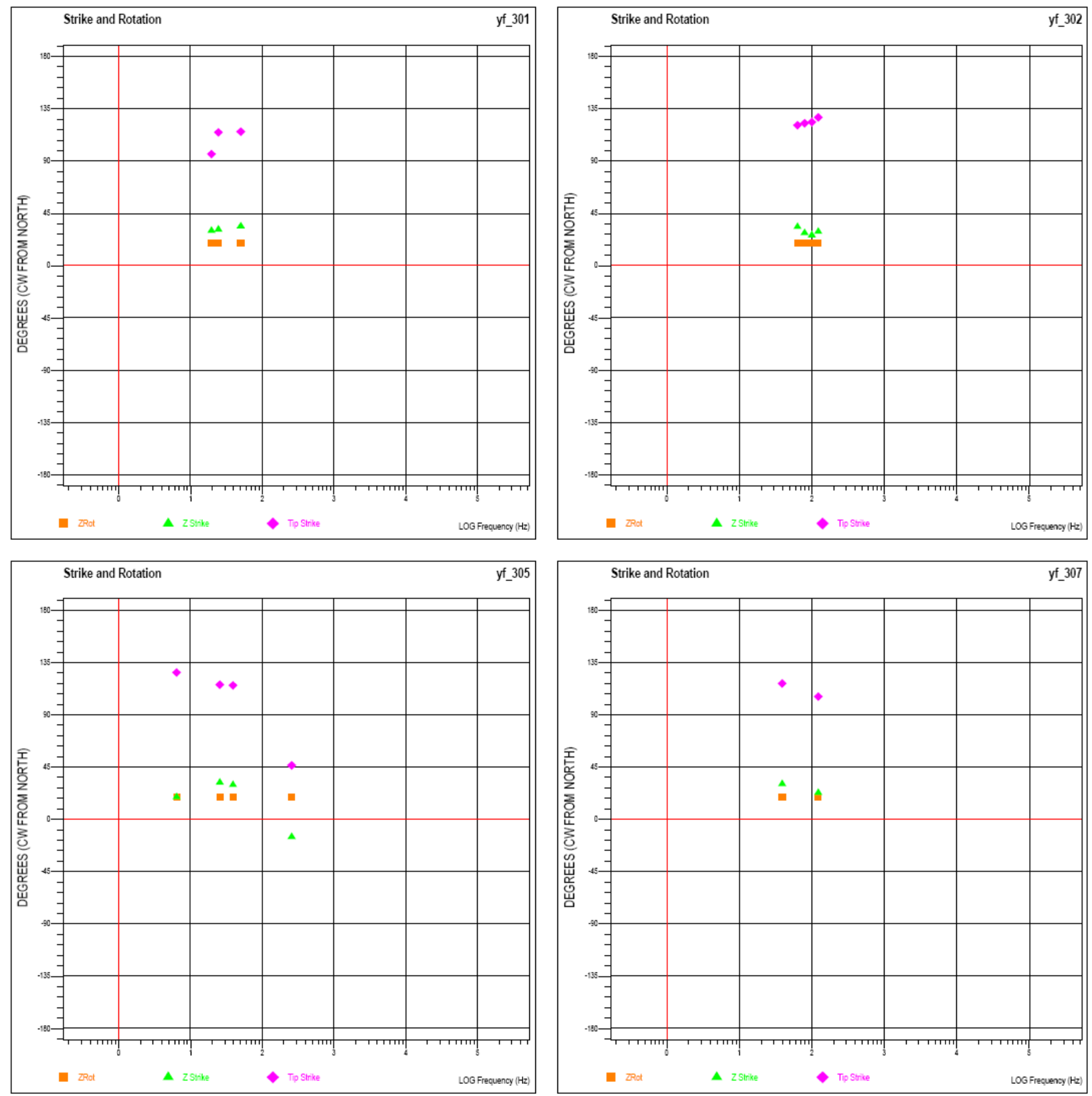

Figure B-114. Impedance strike, rotation, and tipper strike for Line 3, sites 1 to 7. 


\section{U.S. Geological Survey}

Denver Federal Center

Denver, Colorado 80225

MT Data for: L3

Date: 09/19/08
业Geotools

MT Workstation

by

Geotools Corporation

5808 Balcones Dr. Suite 202

Austin, Texas 78731 USA

(512) 454-0679
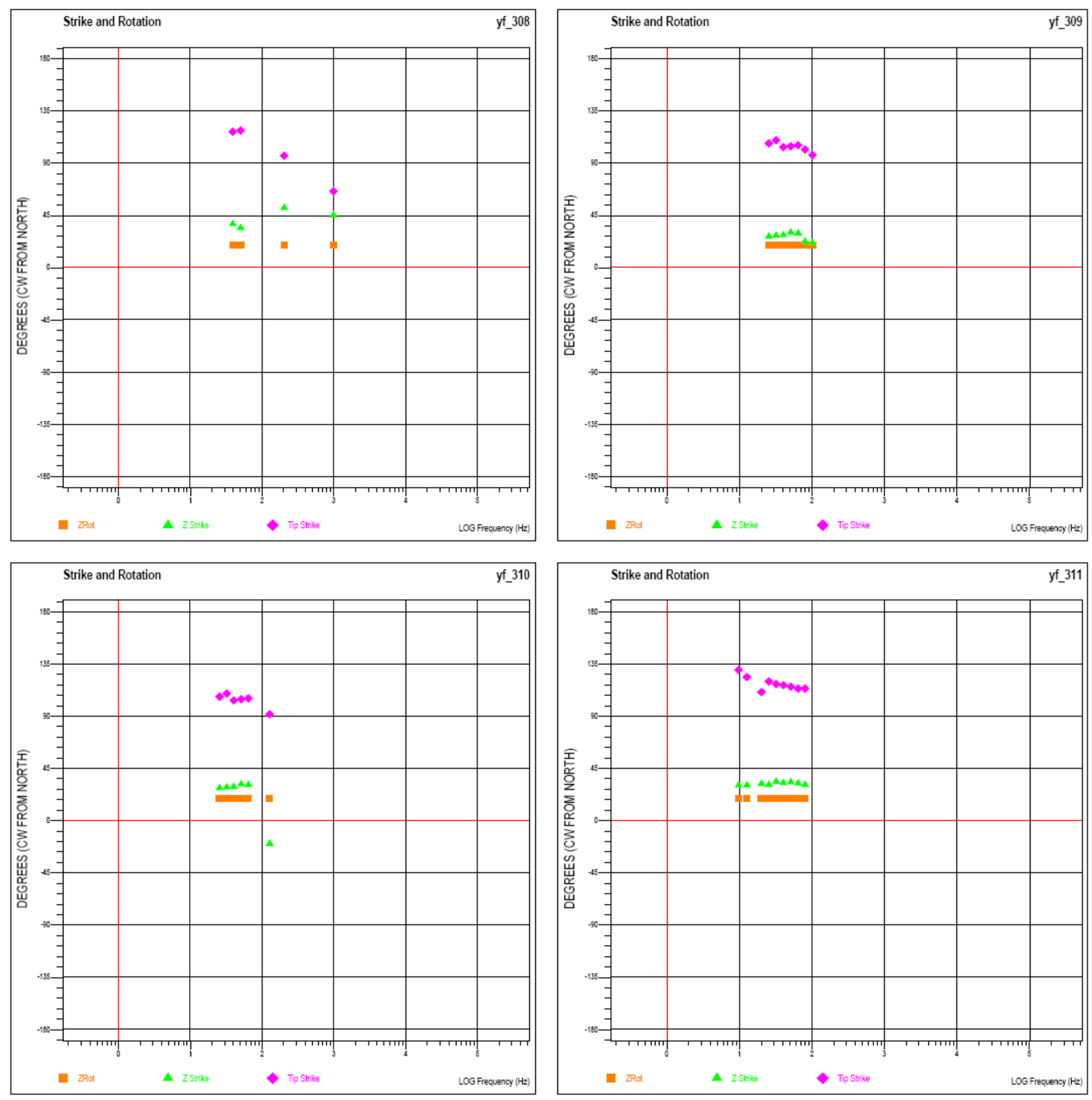

Figure B-115. Impedance strike, rotation, and tipper strike for Line 3, sites 8 to 11 . 


\section{U.S. Geological Survey}

Denver Federal Center

Denver, Colorado 80225

MT Data for: L3

Date: 09/19/08
F Geotools

MT Workstation

by

Geotools Corporation

5808 Balcones Dr. Suite 202

Austin, Texas 78731 USA

(512) 454-0679
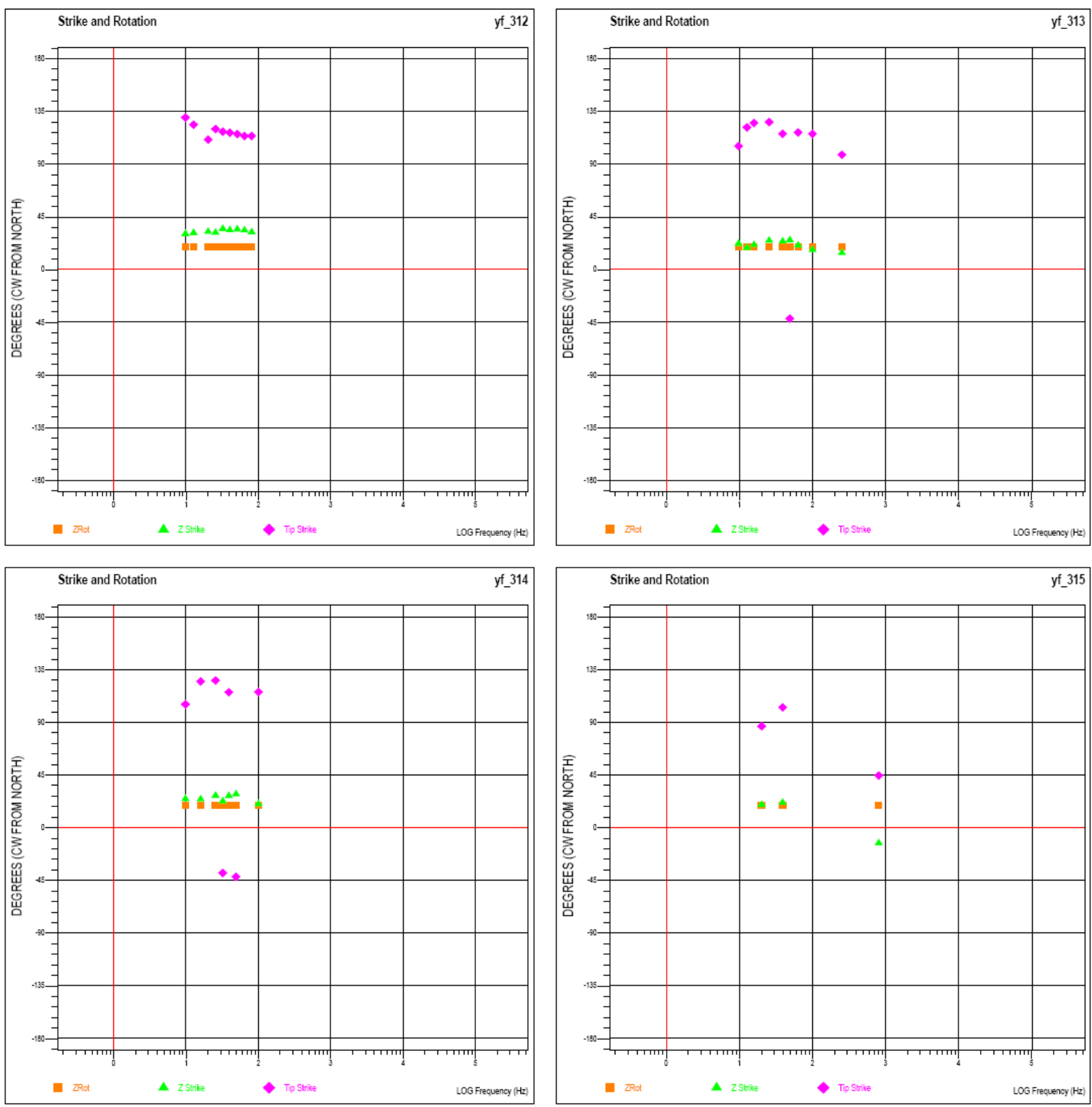

Figure B-116. Impedance strike, rotation, and tipper strike for Line 3, sites 12 to 15. 


\section{U.S. Geological Survey}

Denver Federal Center

Denver, Colorado 80225

MT Data for: L3

Date: 09/19/08
F Geotools

MT Workstation

by

Geotools Corporation

5808 Balcones Dr. Suite 202

Austin, Texas 78731 USA

(512) $454-0679$
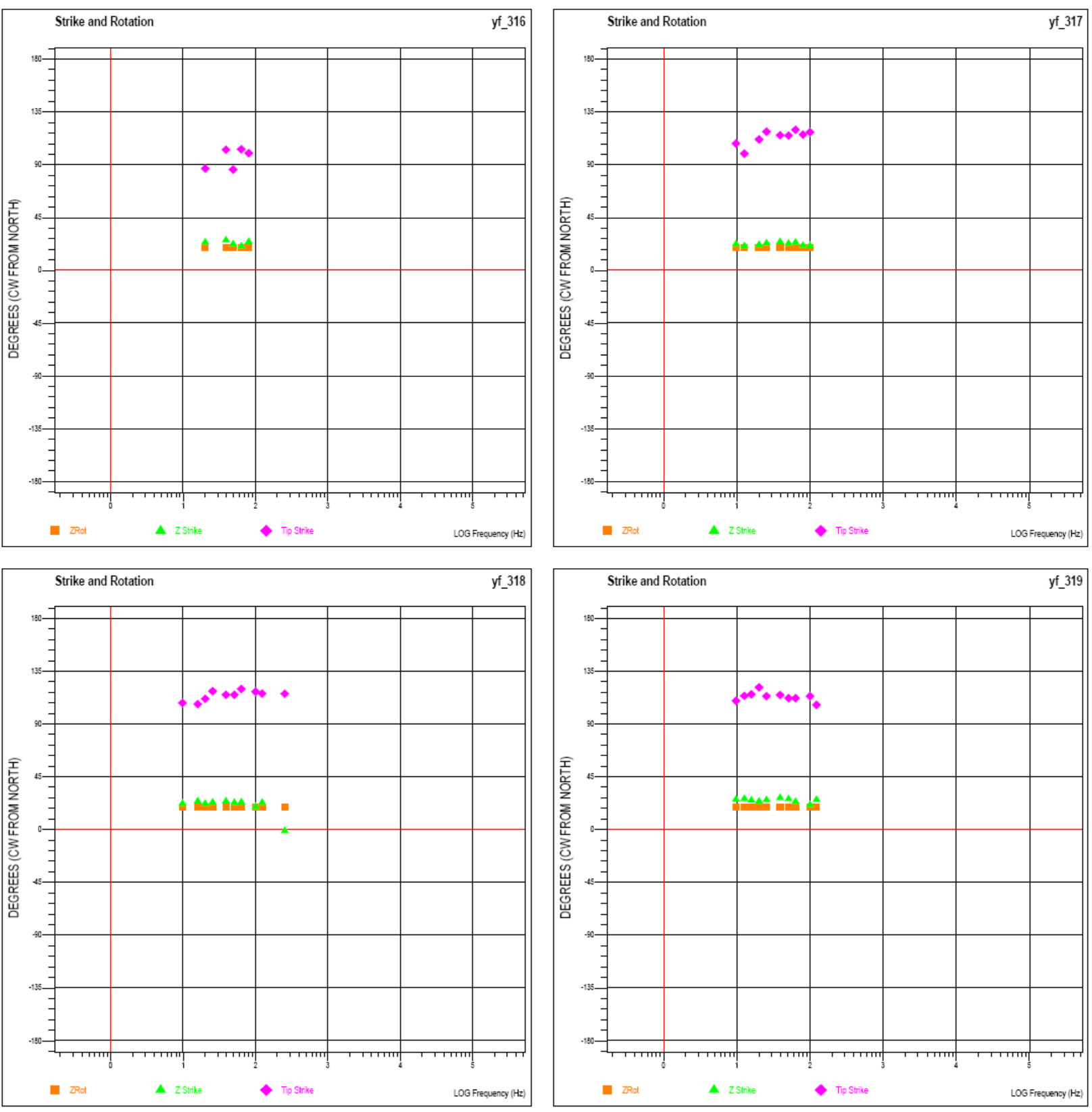

Figure B-117. Impedance strike, rotation, and tipper strike for Line 3, sites 16 to 19. 


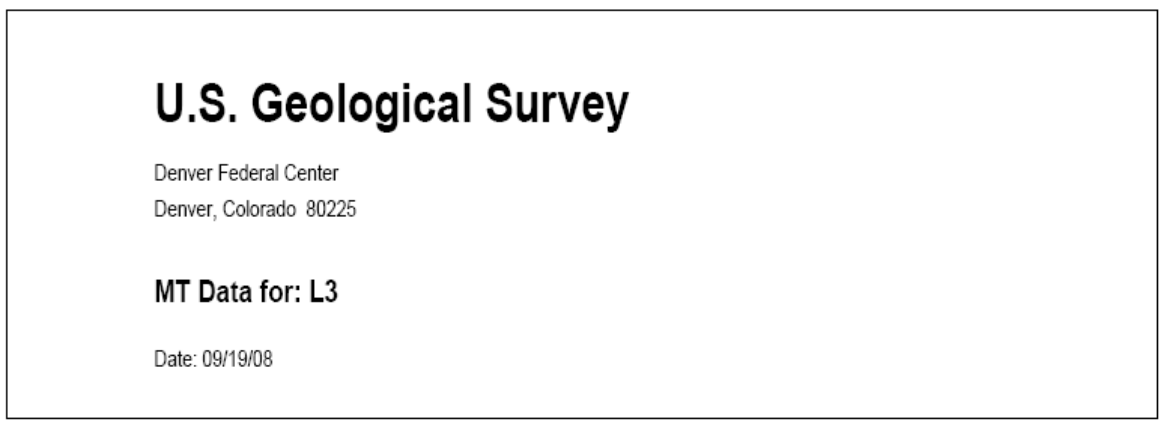

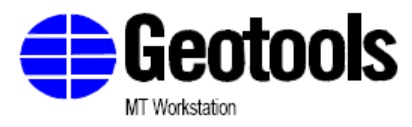

by

Geotools Corporation

5808 Balcones Dr. Sute 202

Austin, Texas 78731 USA

(512) 454-0679

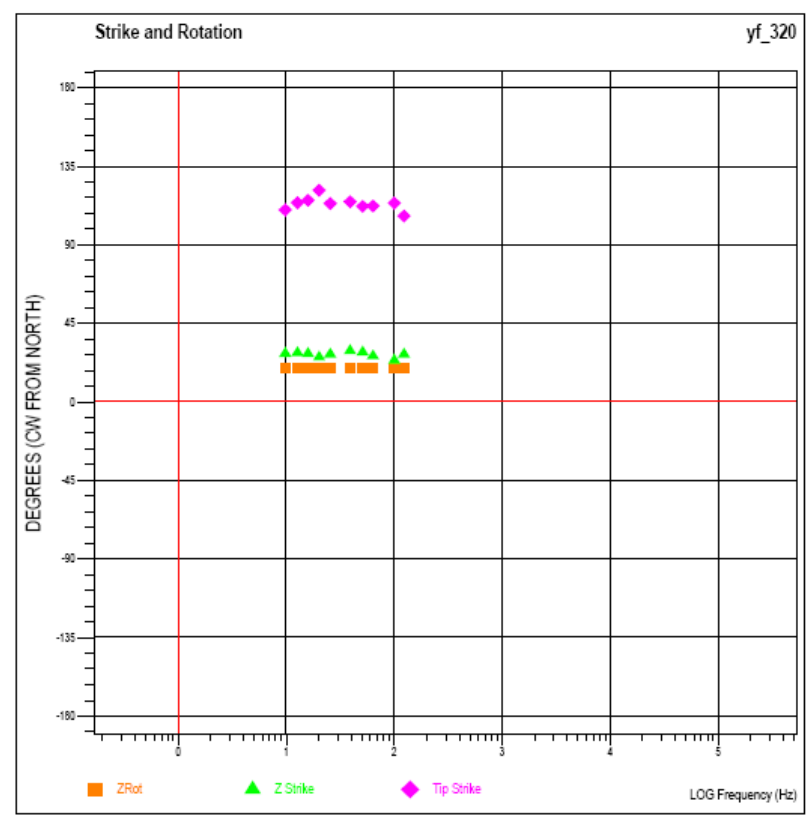

Figure B-118. Impedance strike, rotation, and tipper strike for Line 3, site 20. 


\section{U.S. Geological Survey}

Denver Federal Center

Denver, Colorado 80225

MT Data for: L4

Date: 09/23/08

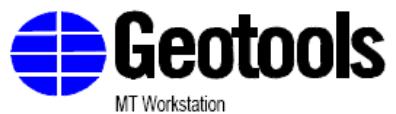

by

Geotools Corporation

5808 Balcones Dr. Sulte 202

Austin, Texas 78731 USA

(512) 454-0679

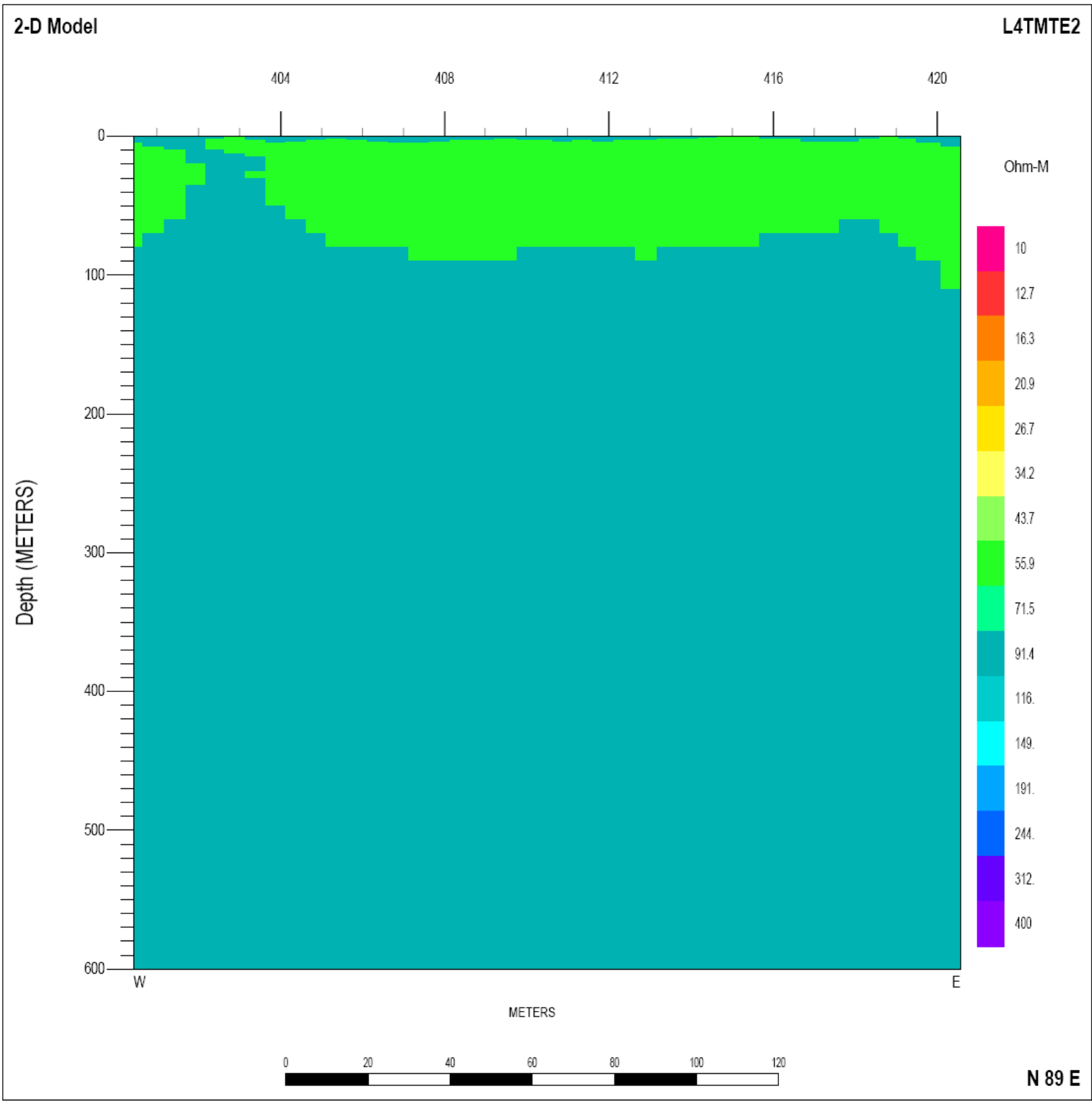

Figure B-119. Two-dimensional inversion model for Line 4 without finite difference mesh. 


\section{U.S. Geological Survey}

\section{Denver Federal Center}

Denver, Colorado 80225

MT Data for: L4

Date: 09/23/08

\section{垂Geotools \\ MT Workstation}

by

Geotools Corporation

5808 Balcones Dr. Suite 202

Austin, Texas 78731 USA

(512) 454-0679

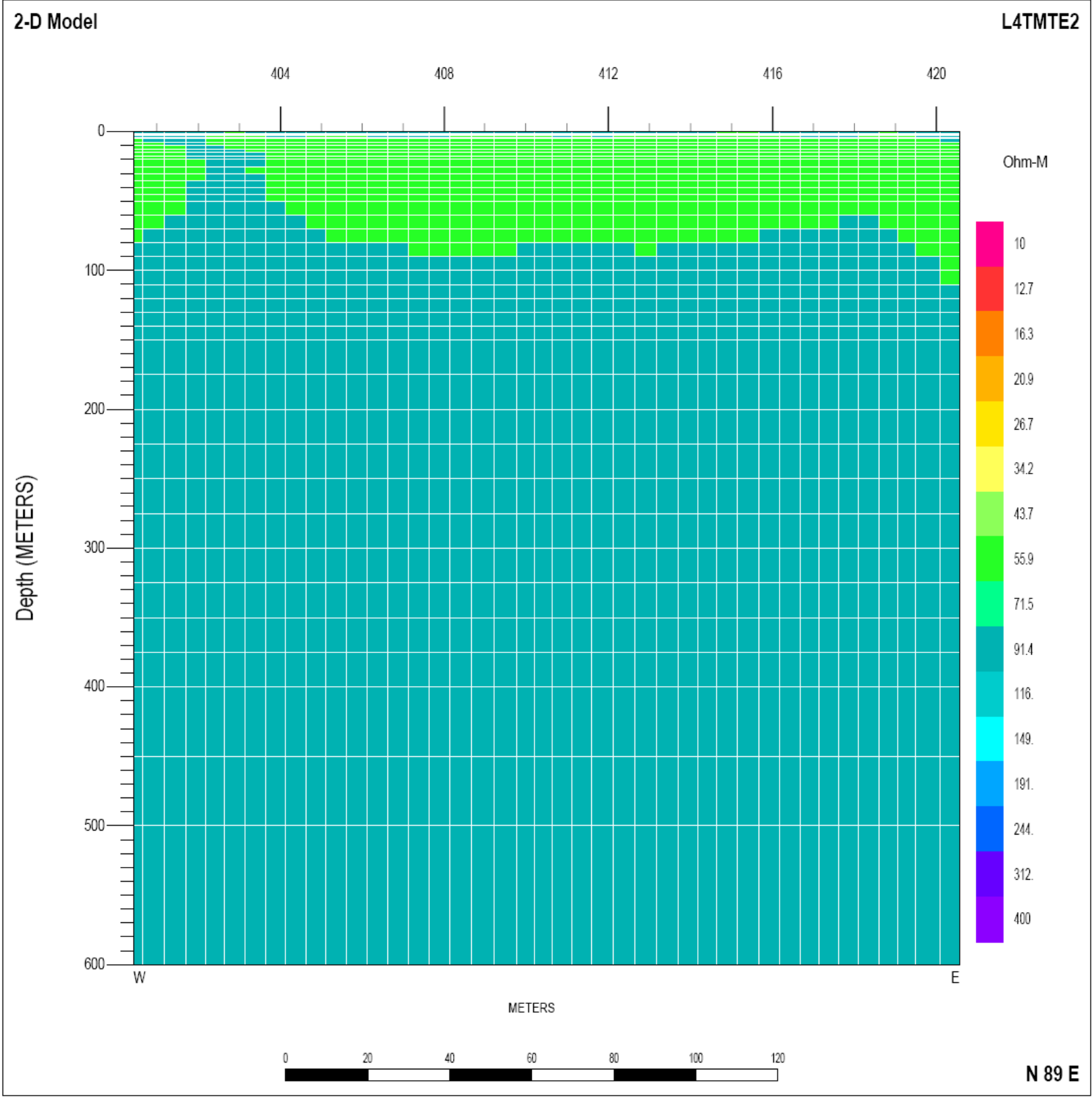

Figure B-120. Two-dimensional inversion model for Line 4 with finite difference mesh. 


\section{U.S. Geological Survey}

Denver Federal Center

Denver, Colorado 80225

MT Data for: L4

Date: 09/18/08

平Geotools

by

Geotools Corporation

5808 Balcones Dr. Sute 202

Austin, Texas 78731 USA

(512) 454-0679
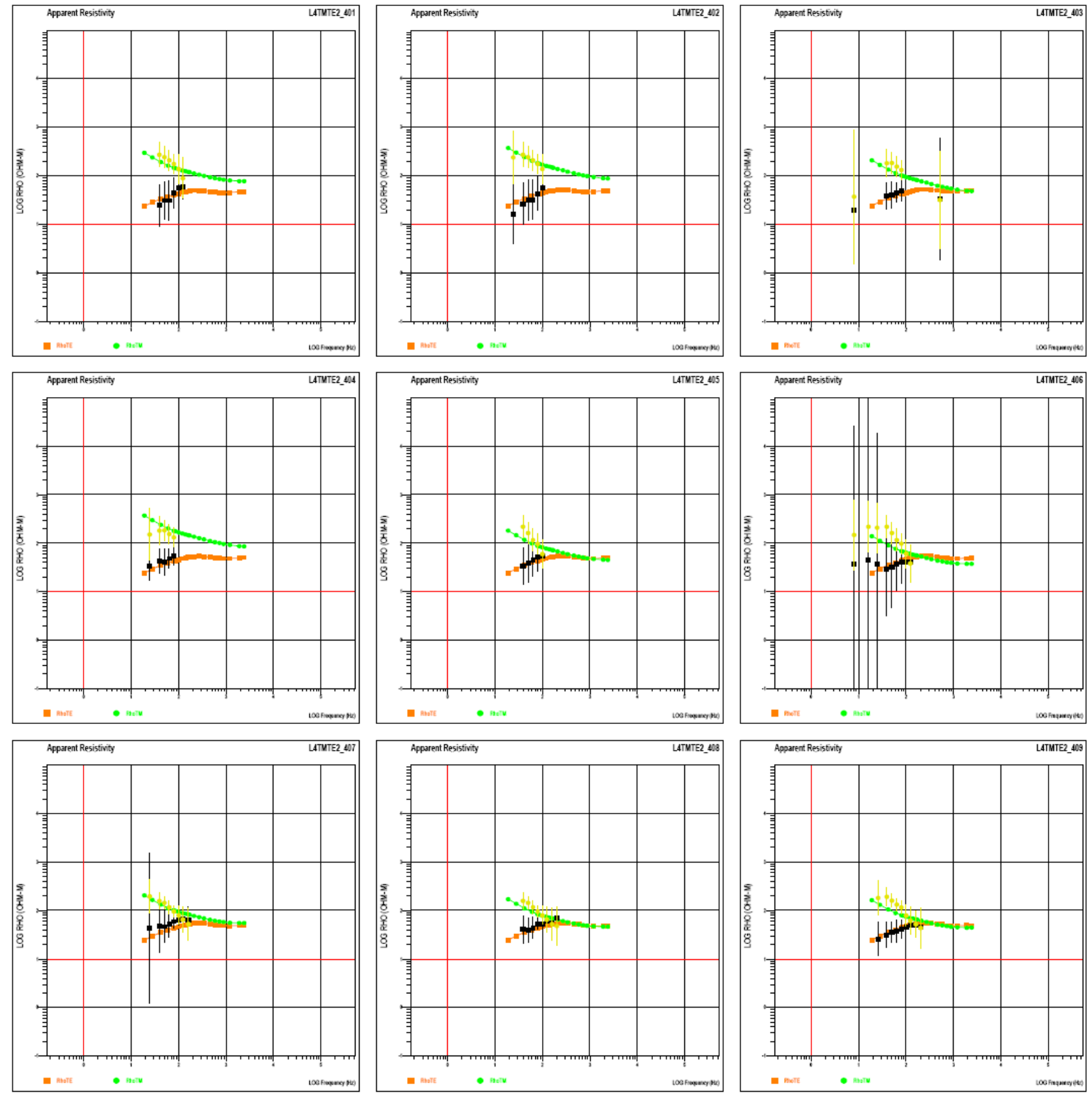

Figure B-121. Apparent resistivity data for Line 4, sites 1 to 9. 


\section{U.S. Geological Survey}

Denver Federal Center

Denver, Colorado 80225

MT Data for: L4

Date: $09 / 18 / 08$
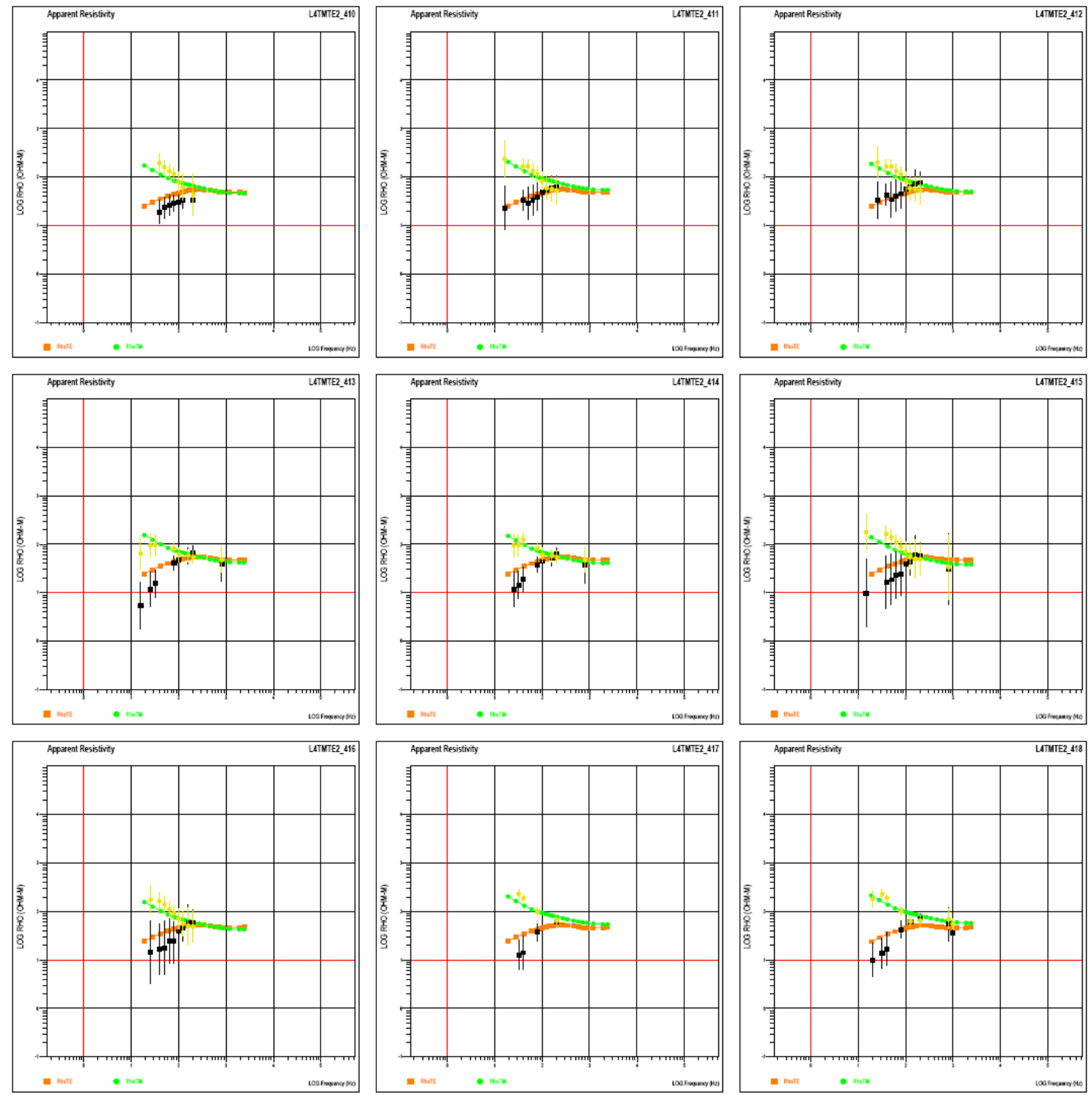

Figure B-122. Apparent resistivity data for Line 4, sites 10 to 18. 


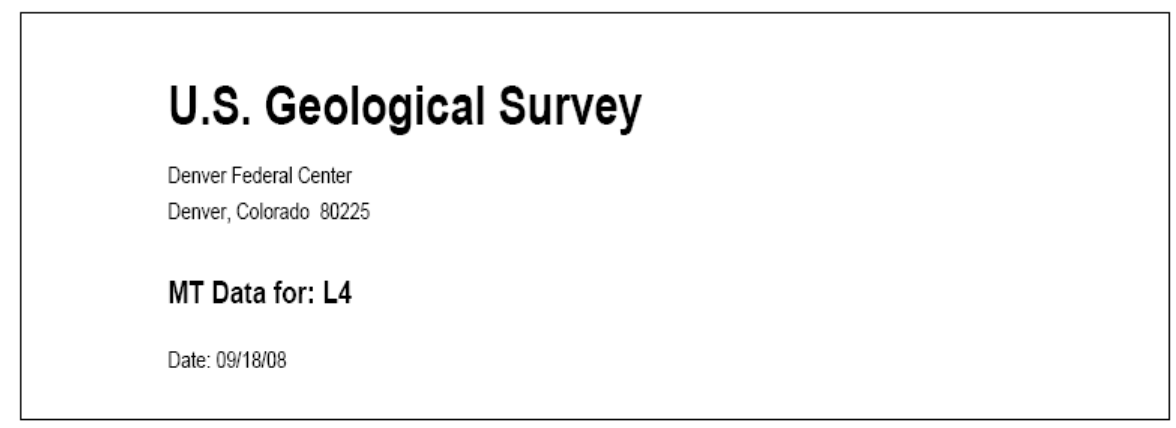

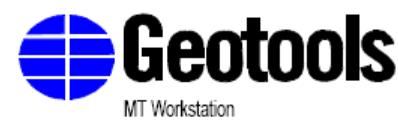

by

Geotools Corporation

5808 Balcones Dr. Sute 202

Austin, Texas 78731 USA

(512) 454-0679
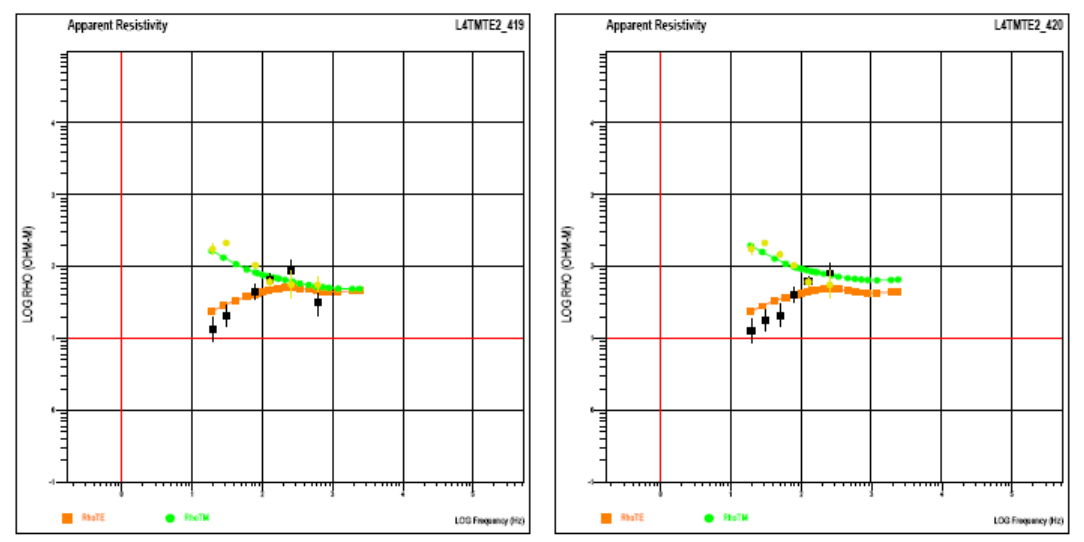

Figure B-123. Apparent resistivity data for Line 4, sites 19 and 20. 


\section{U.S. Geological Survey}

Denver Federal Center

Denver, Colorado 80225

MT Data for: L4

Date: 09/18/08
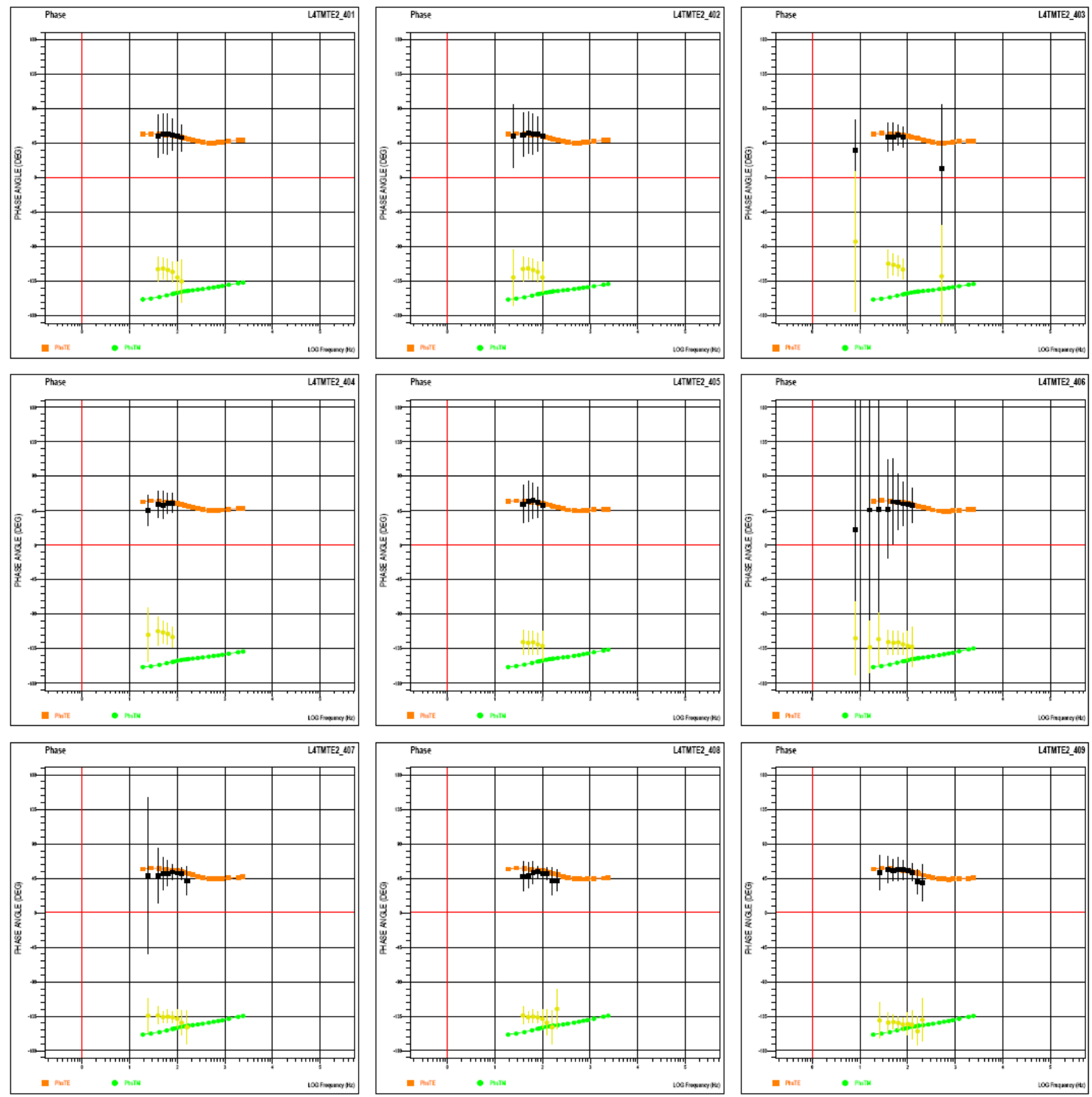

Figure B-124. Impedance phase data for Line 4, sites 1 to 9. 


\section{U.S. Geological Survey}

Denver Federal Center

Denver, Colorado 80225

MT Data for: L4

Date: $09 / 18 / 08$

车Geotools

MT Workstation

by

Geotools Corporation

5808 Balcones Dr. Sute 202

Austin, Texas 78731 USA

(512) $454-0679$
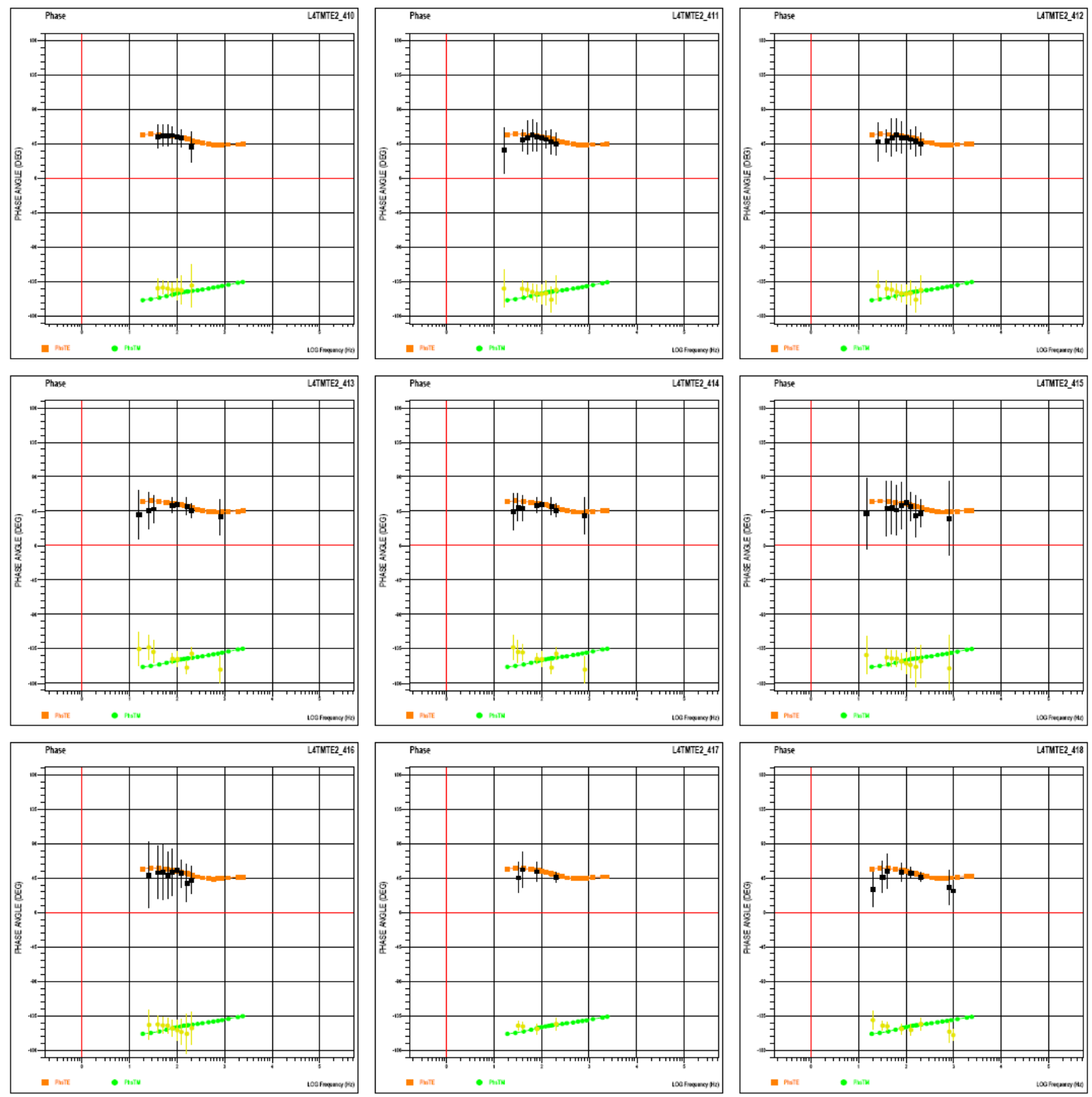

Figure B-125. Phase data for Line 4, sites 10 to 18 . 

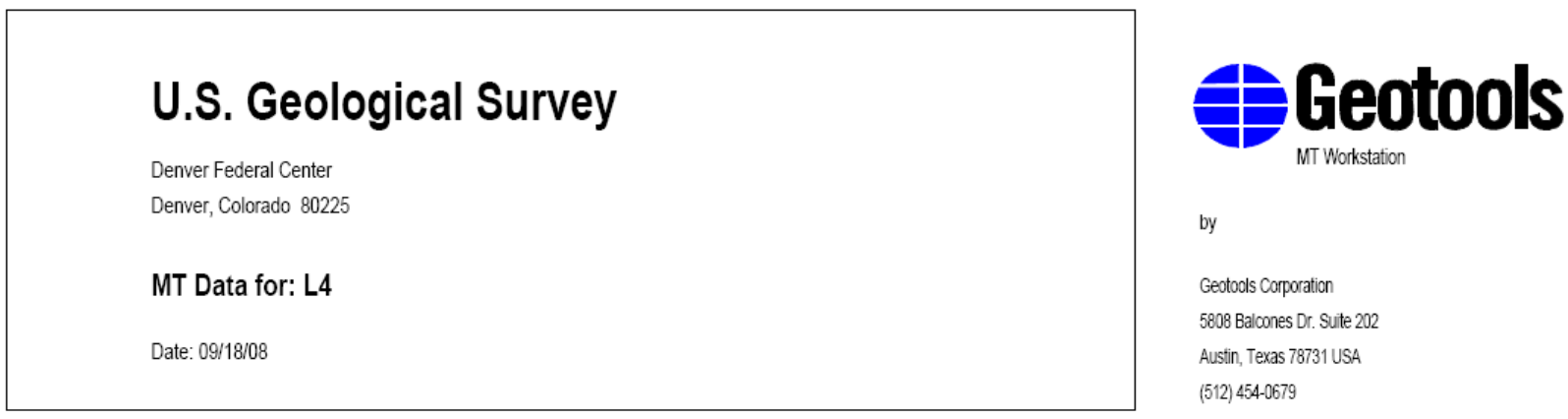

by

Geotools Corporation

5808 Balcones Dr. Sute 202

Ausin, Texas 78731 USA

(512) 454.0679
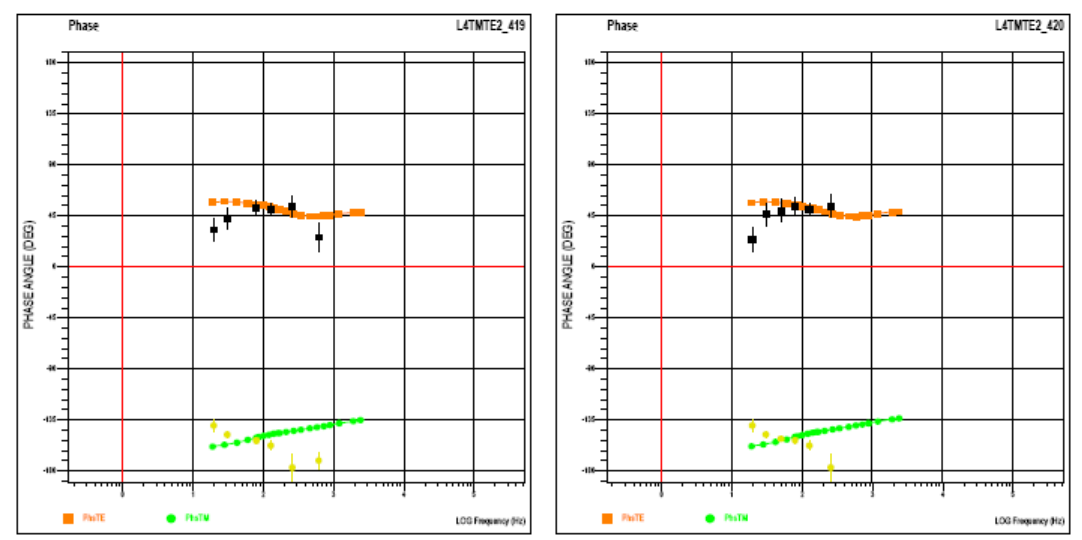

Figure B-126. Phase data for Line 4, sites 19 and 20. 


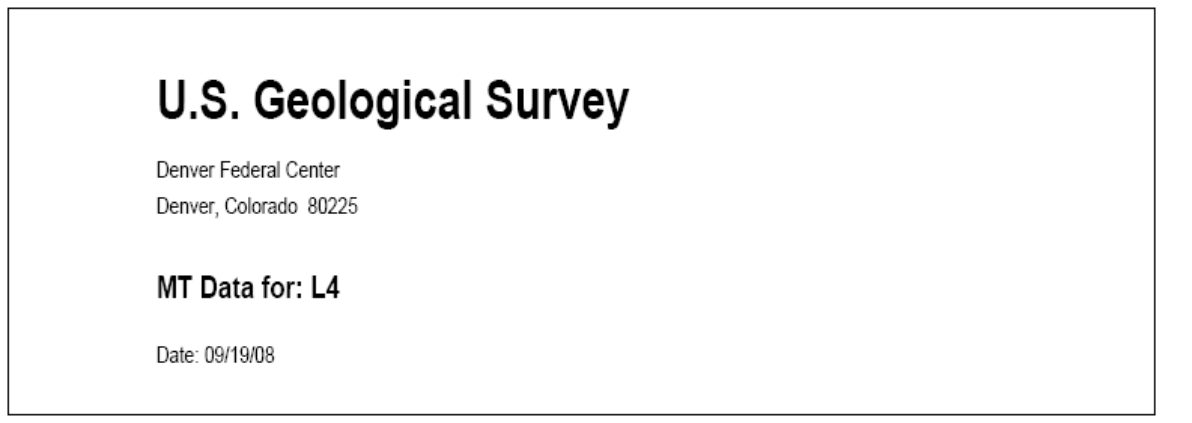

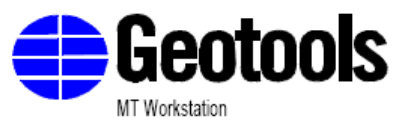

by

Geotools Corporation

5808 Balcones Dr. Suite 202

Austin, Texas 78731 USA

(512) 454-0679
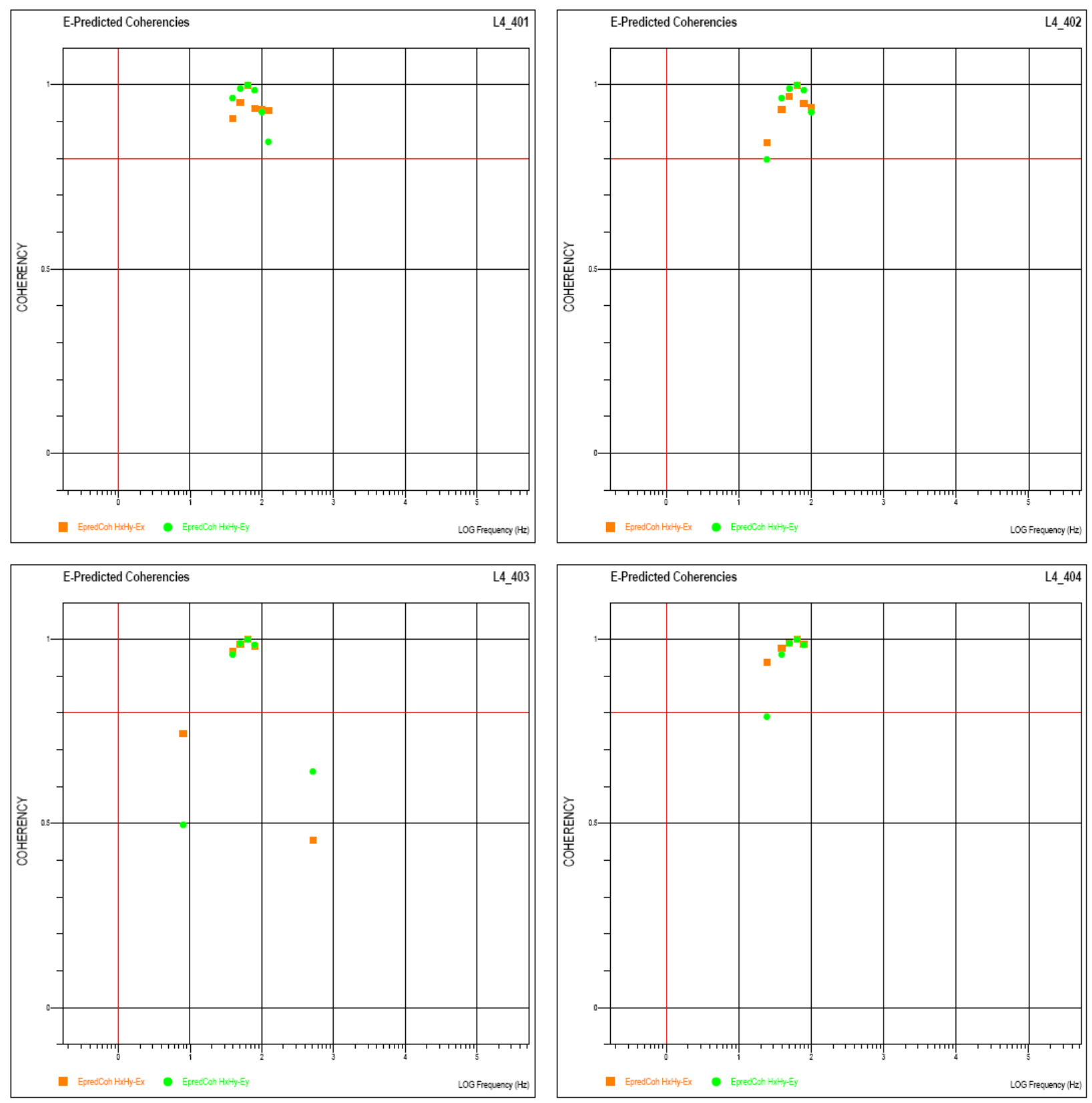

Figure B-127. E-predicted coherencies for Line 4, sites 1 to 4. 


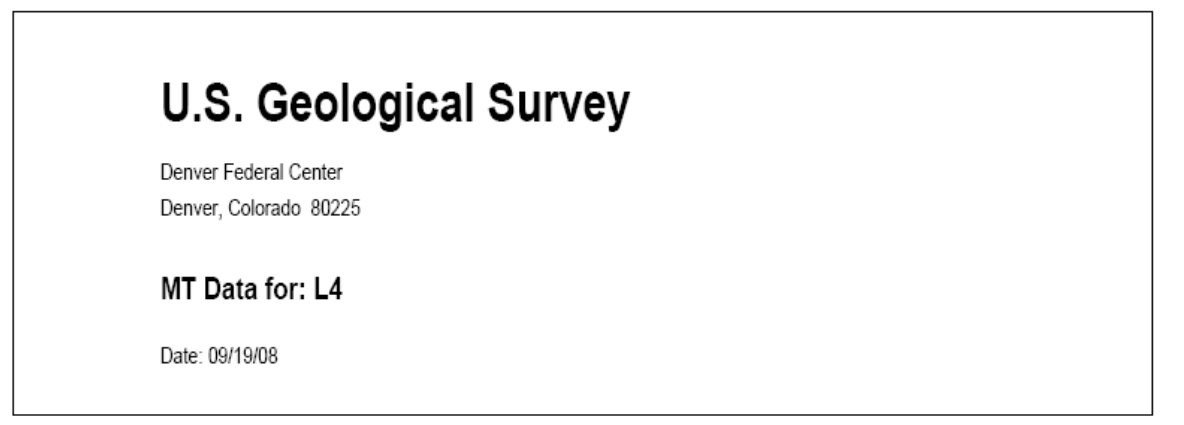

F Geotools

by

Geotools Corporation

5808 Balcones Dr. Suite 202

Austin, Texas 78731 USA

(512) 454-0679
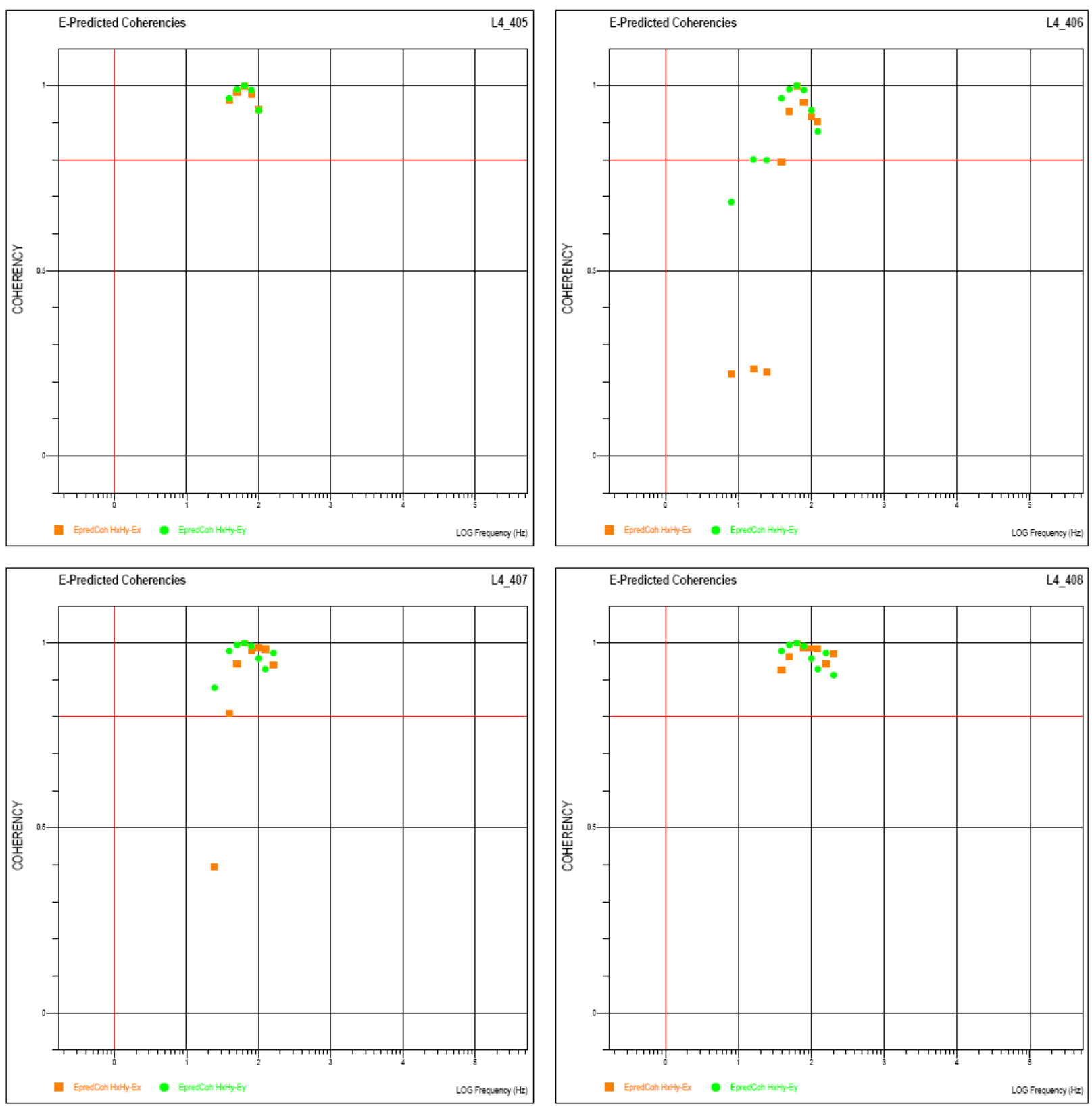

Figure B-128. E-predicted coherencies for Line 4, sites 5 to 8. 


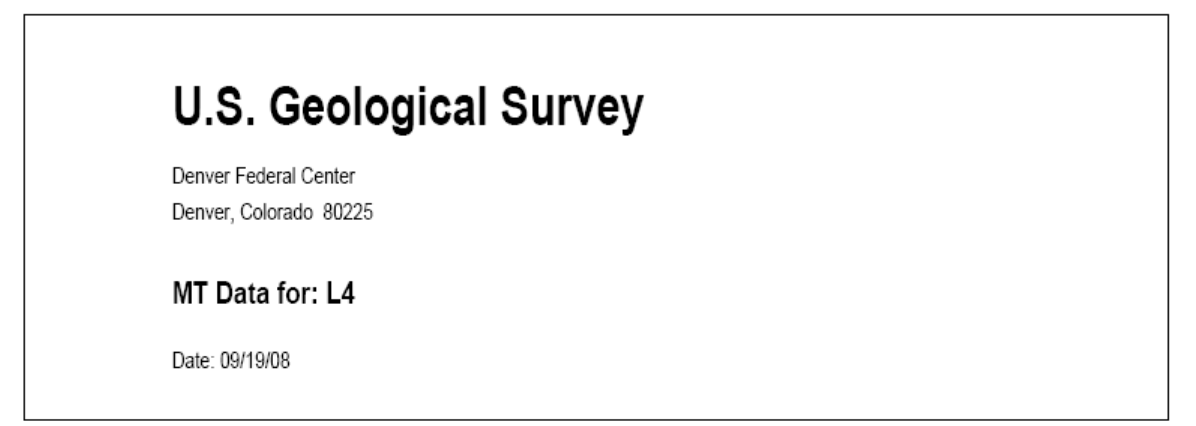

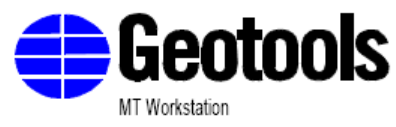

by

Geotools Corporation

5808 Balcones Dr. Suite 202

Austin, Texas 78731 USA

(512) $454-0679$
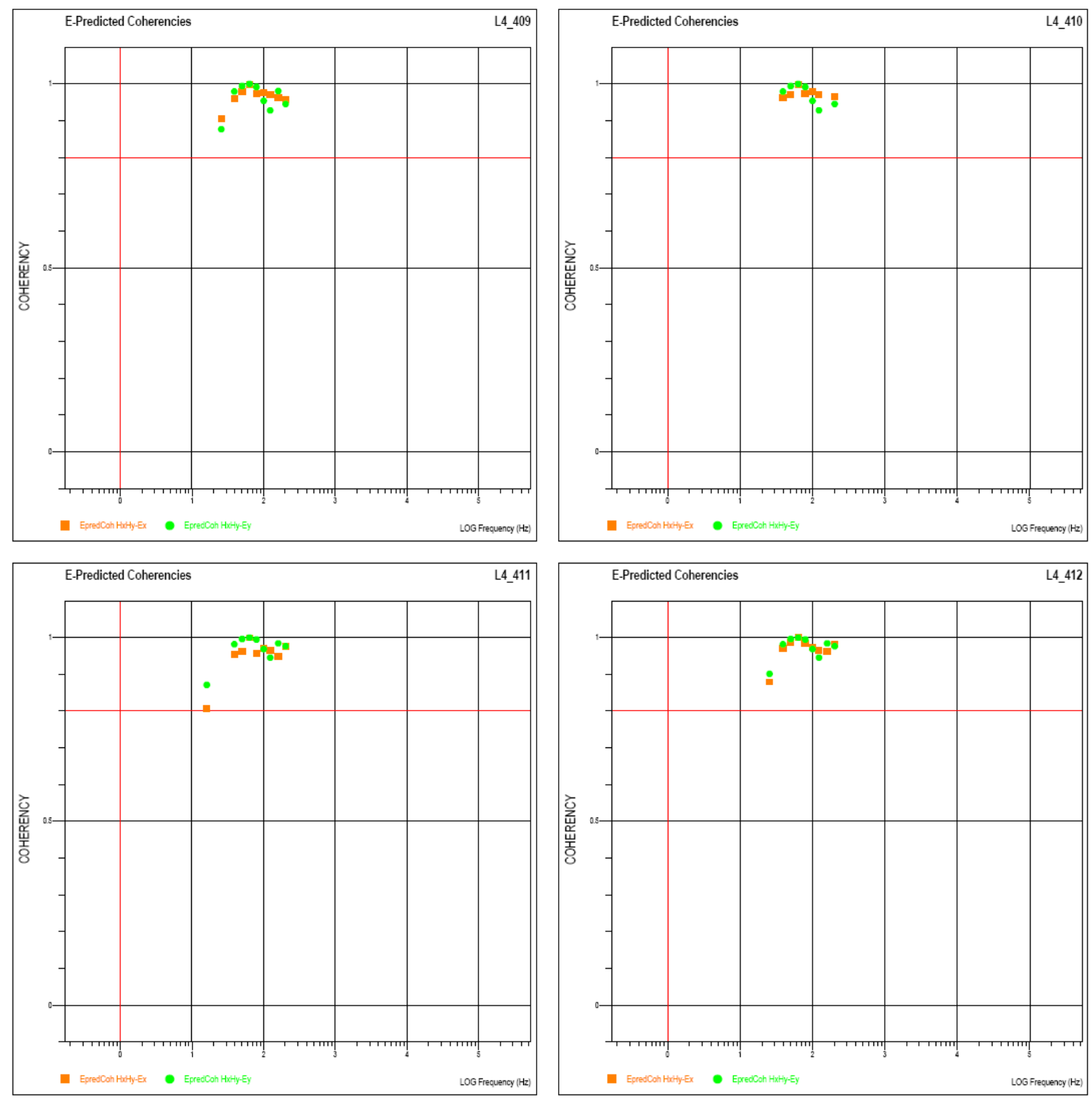

Figure B-129. E-predicted coherencies for Line 4, sites 9 to 12. 

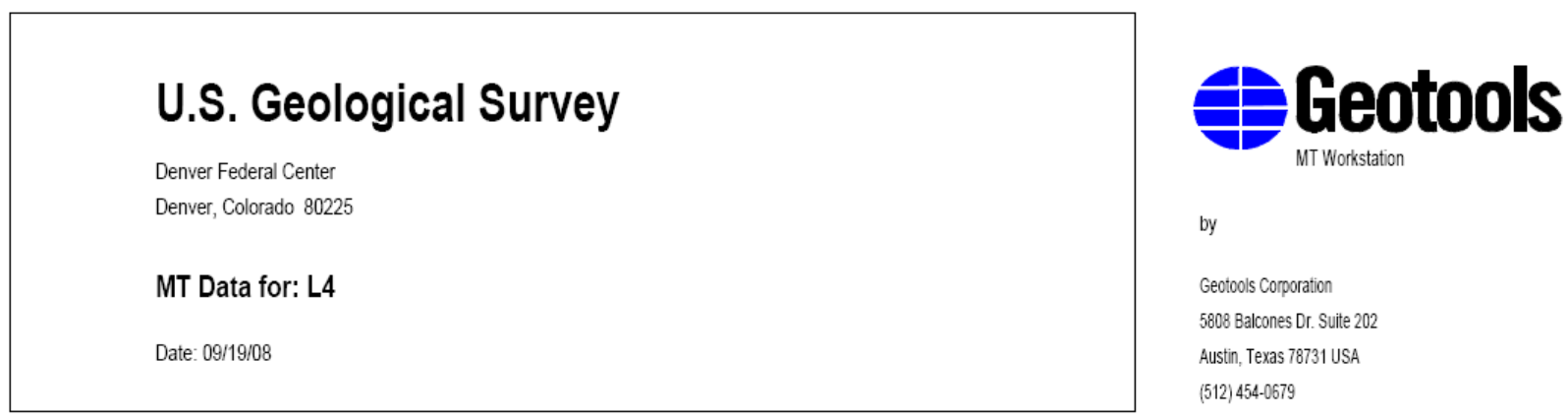

by

Geotools Corporation

5808 Balcones Dr. Suite 202

Austin, Texas 78731 USA

(512) 454-0679
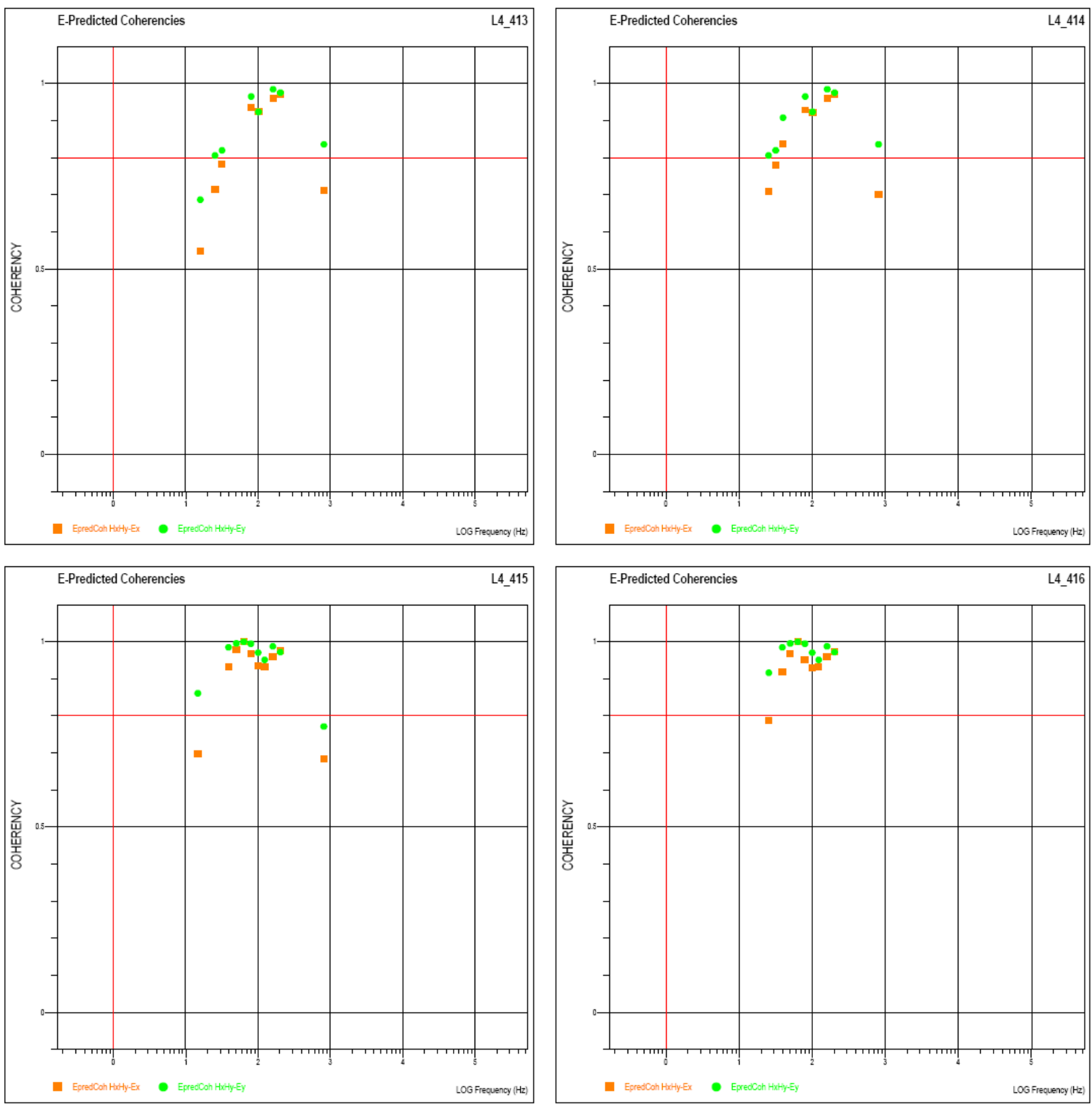

Figure B-130. E-predicted coherencies for Line 4, sites 13 to 16. 


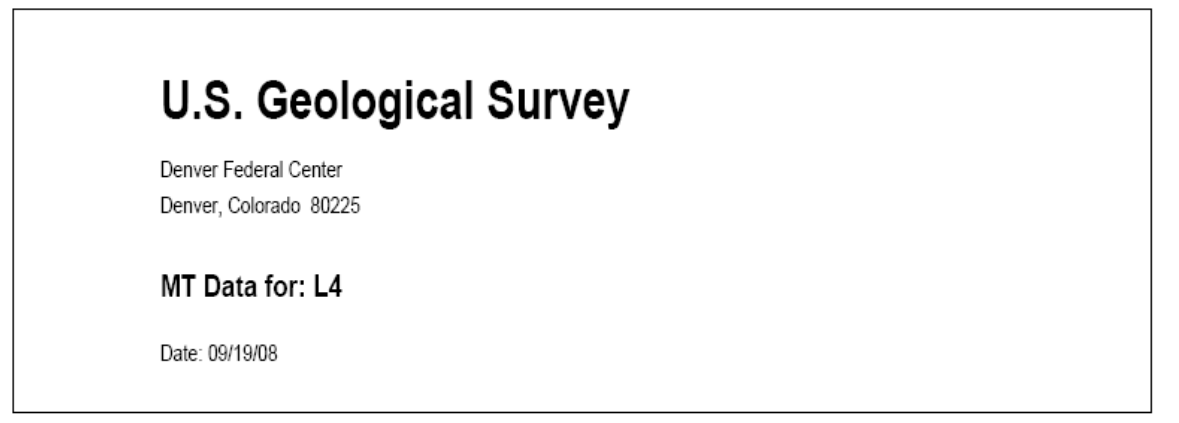

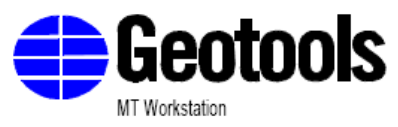

by

Geotools Corporation

5808 Balcones Dr. Suite 202

Austin, Texas 78731 USA

(512) 454-0679
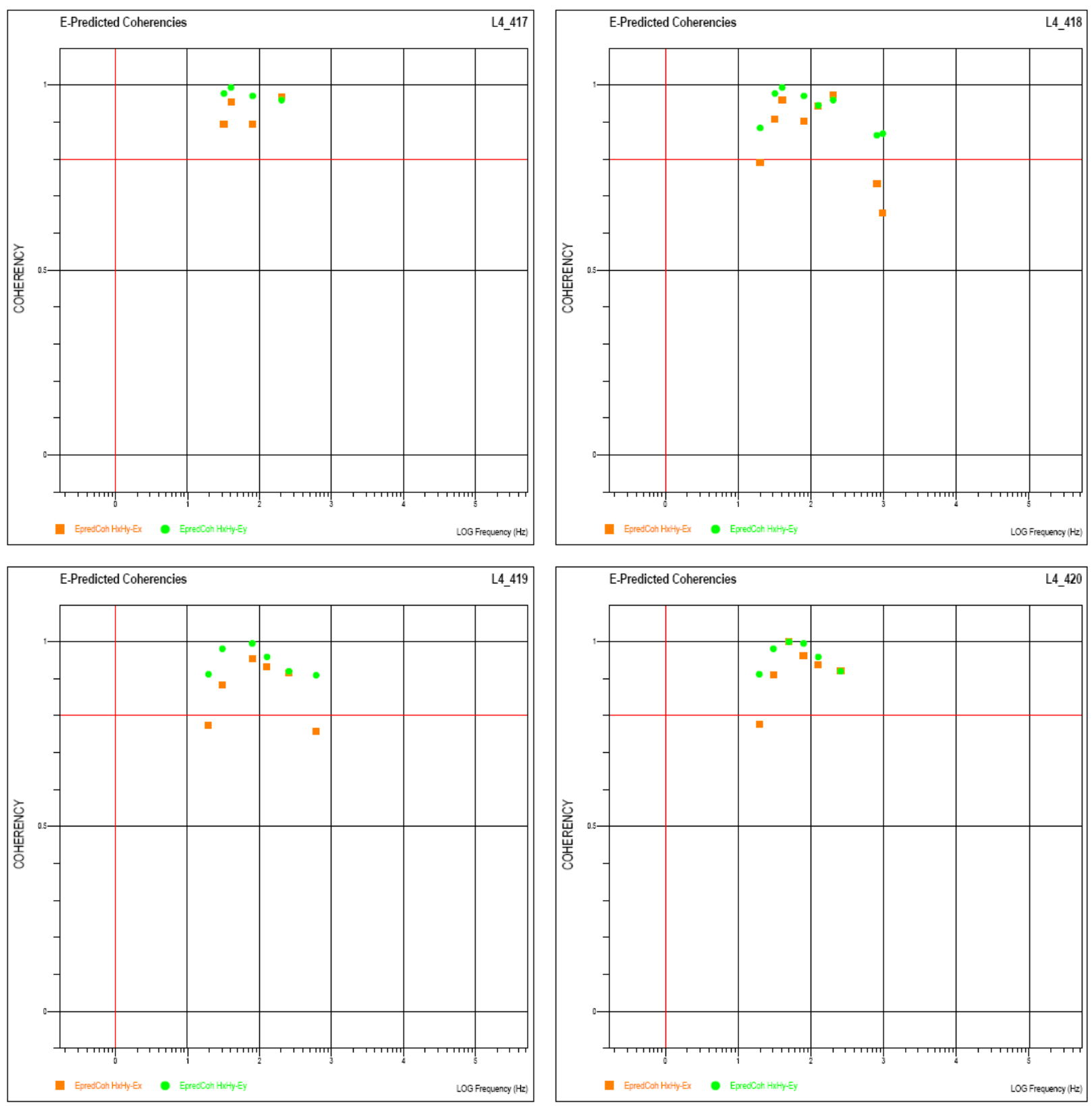

Figure B-131. E-predicted coherencies for Line 4, sites 17 to 20. 


\section{U.S. Geological Survey}

Denver Federal Center

Denver, Colorado 80225

MT Data for: L4

Date: 09/19/08
FGeotools

MT Workstation

by

Geotools Corporation

5808 Balcones Dr. Suite 202

Austin, Texas 78731 USA

(512) 454-0679
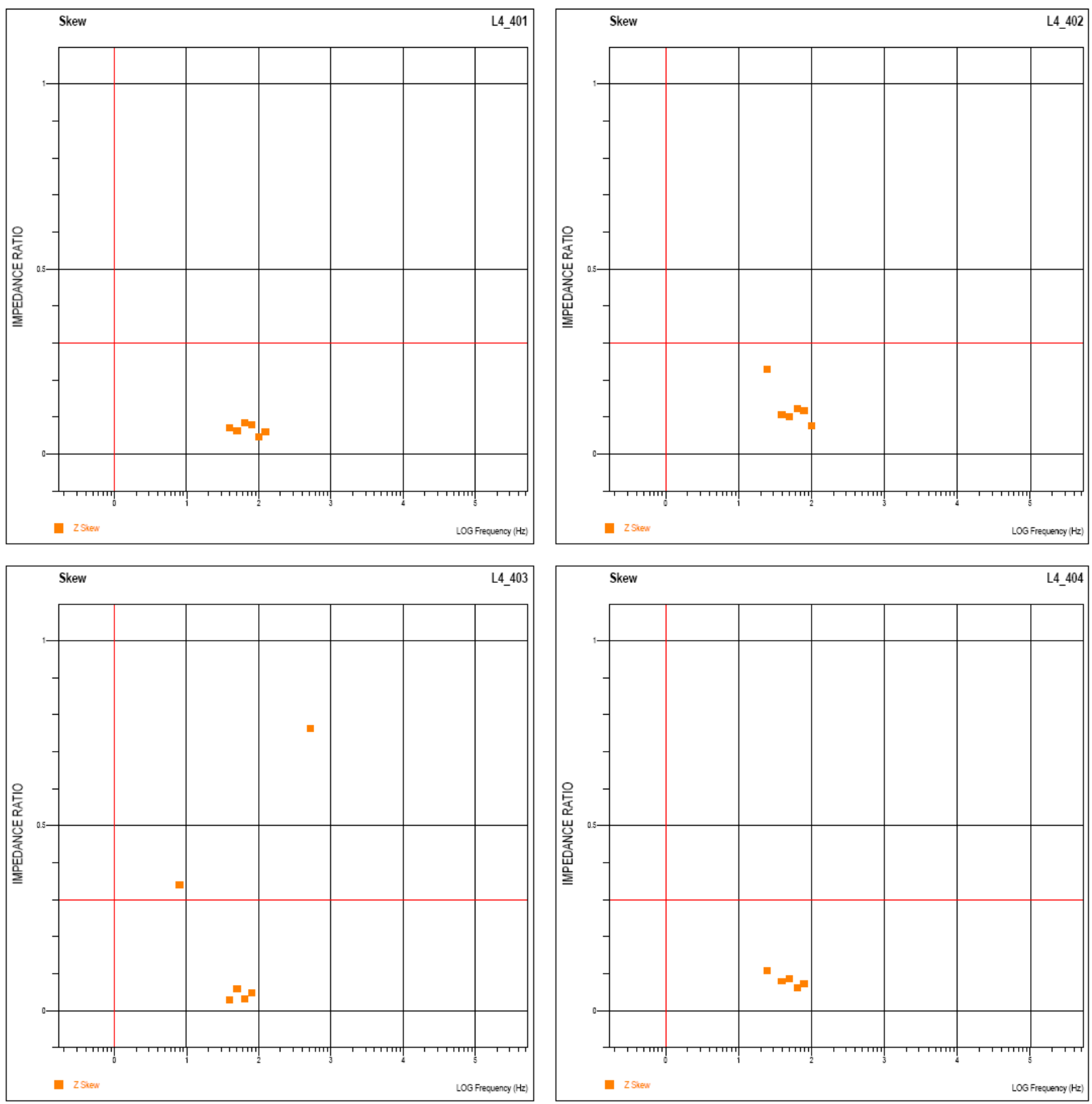

Figure B-132. Impedance skews for Line 4, sites 1 to 4. 


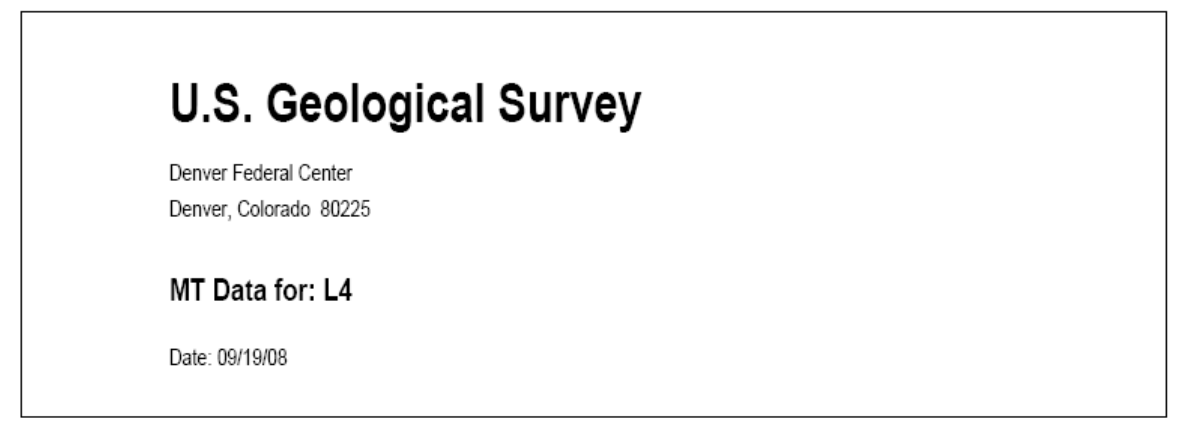

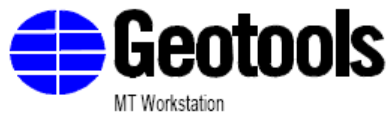

by

Geotools Corporation

5808 Balcones Dr. Suite 202

Austin, Texas 78731 USA

(512) 454-0679
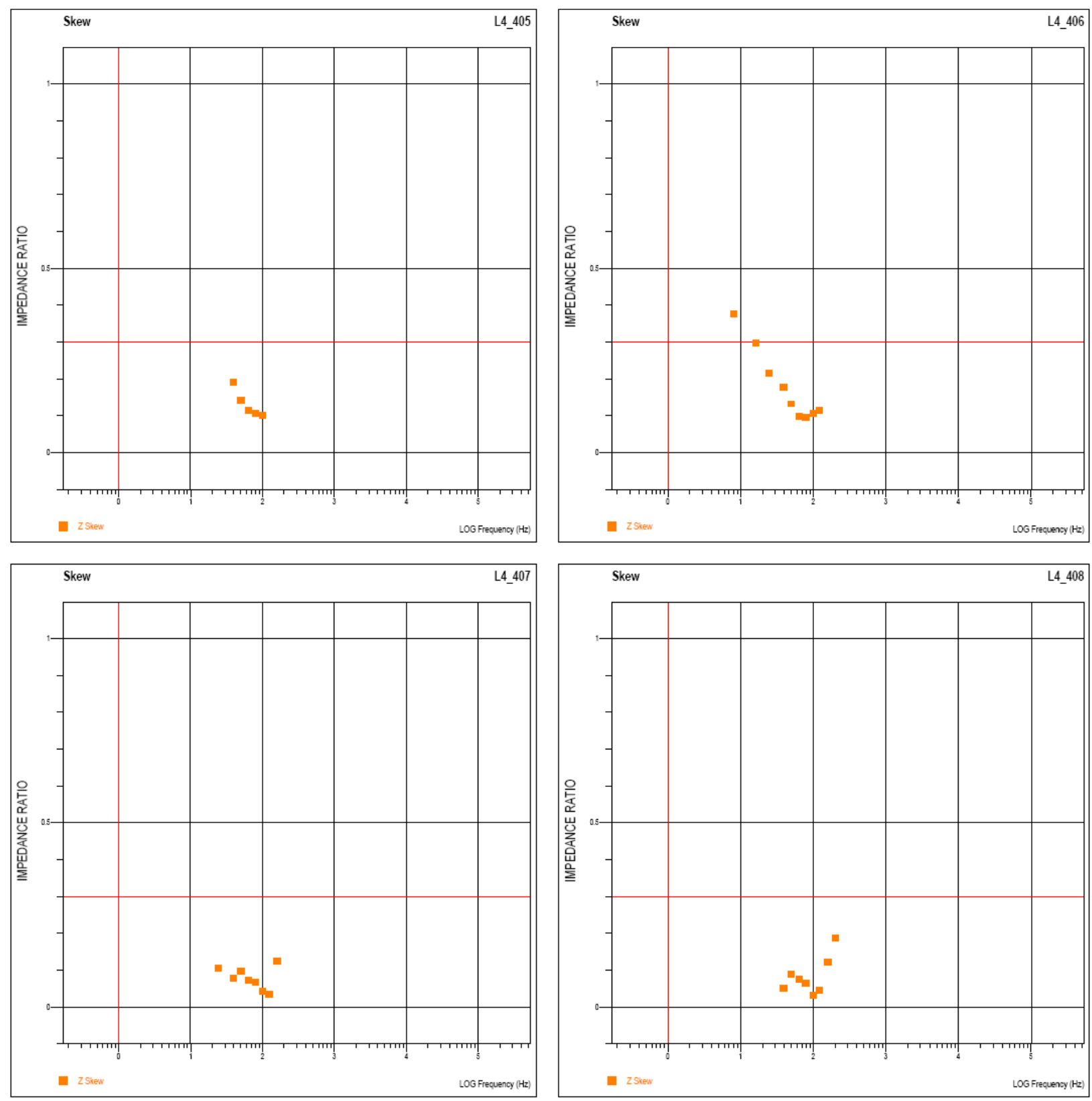

Figure B-133. Impedance skews for Line 4, sites 5 to 8 . 


\section{U.S. Geological Survey}

Denver Federal Center

Denver, Colorado 80225

MT Data for: L4

Date: 09/19/08
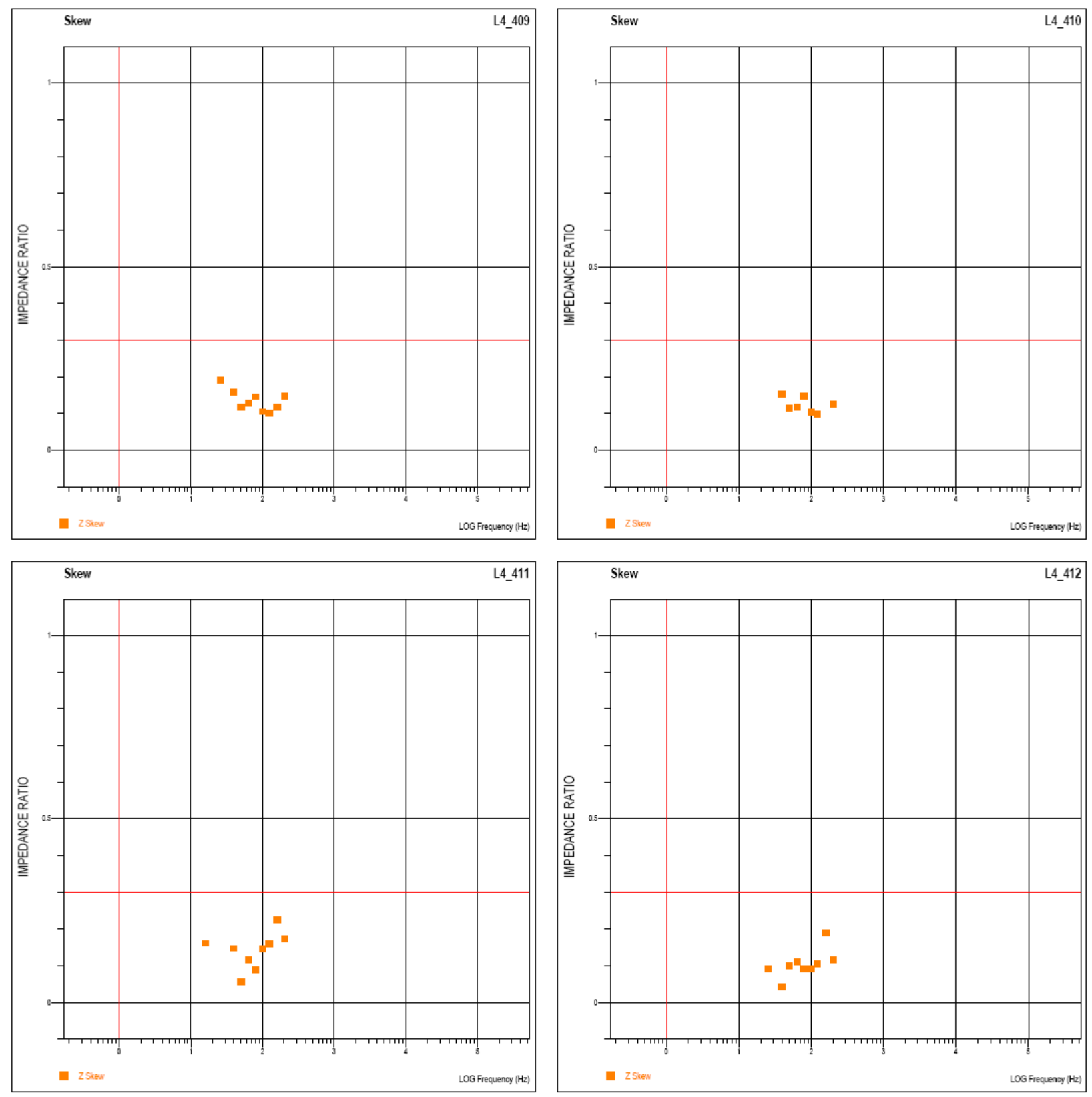

Figure B-134. Impedance skews for Line 4, sites 9 to 12. 


\section{U.S. Geological Survey}

Denver Federal Center

Denver, Colorado 80225

MT Data for: L4

Date: 09/19/08
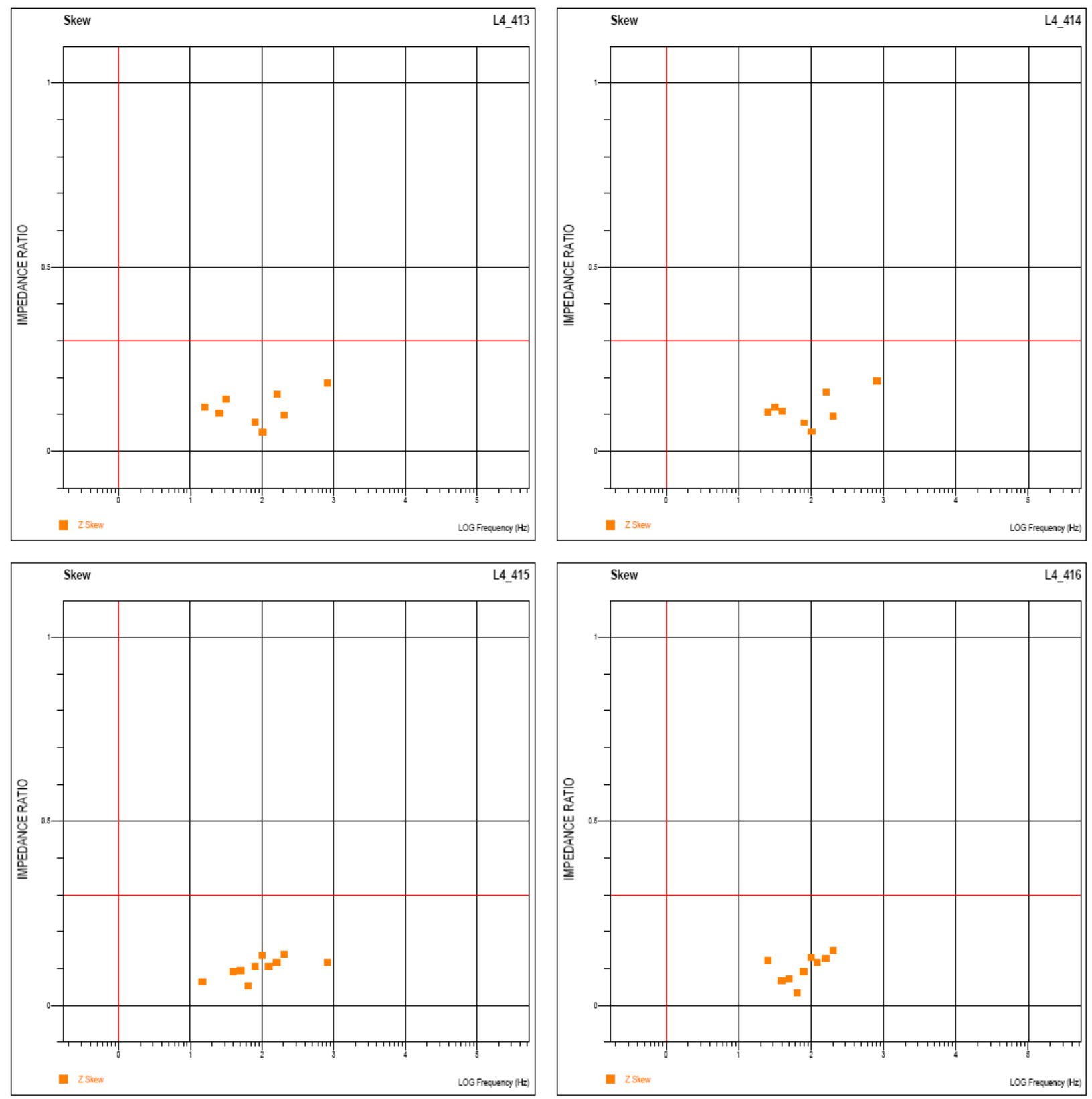

Figure B-135. Impedance skews for Line 4, sites 13 to 16. 

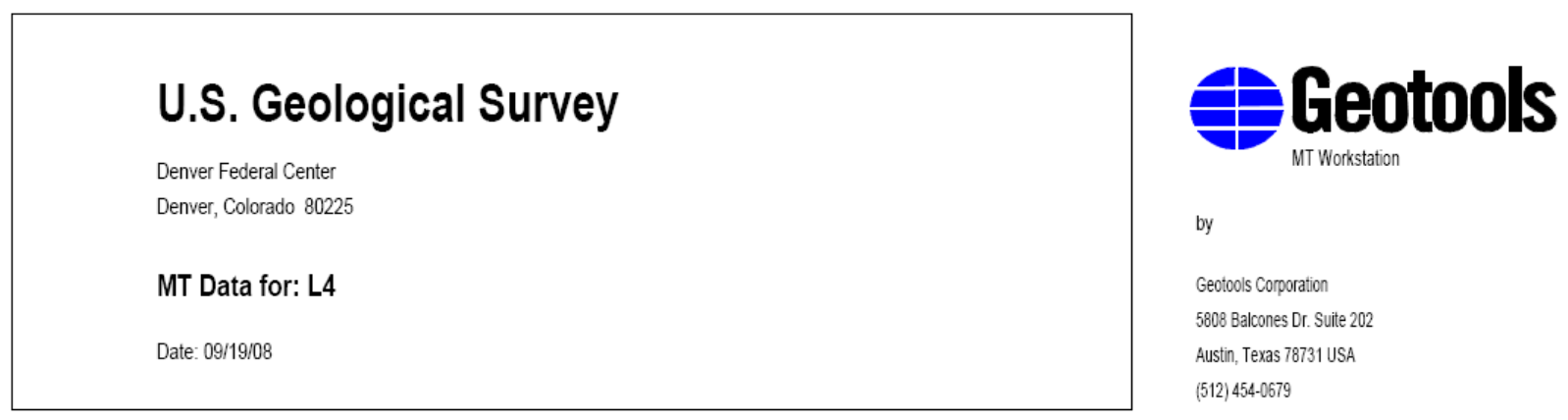

by

Geotools Corporation

5808 Balcones Dr. Suite 202

Austin, Texas 78731 USA

(512) 454-0679
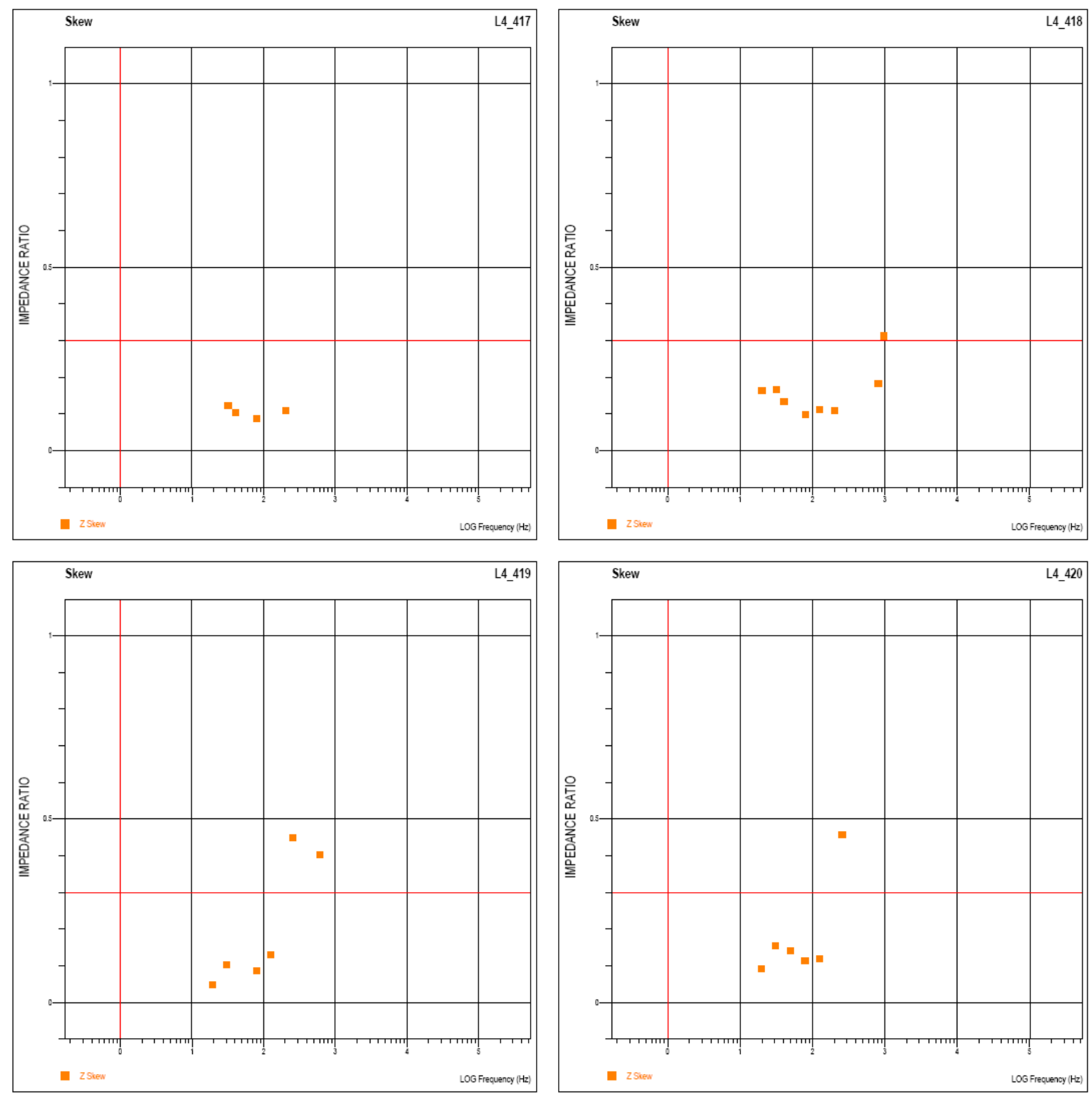

Figure B-136. Impedance skews for Line 4, sites 17 to 20. 


\section{U.S. Geological Survey}

Denver Federal Center

Denver, Colorado 80225

MT Data for: L4

Date: 09/18/08
F Geotools

by

Geotools Carporation

5808 Balcones Dr. Suite 202

Austin, Texas 78731 USA

(512) 454-0679
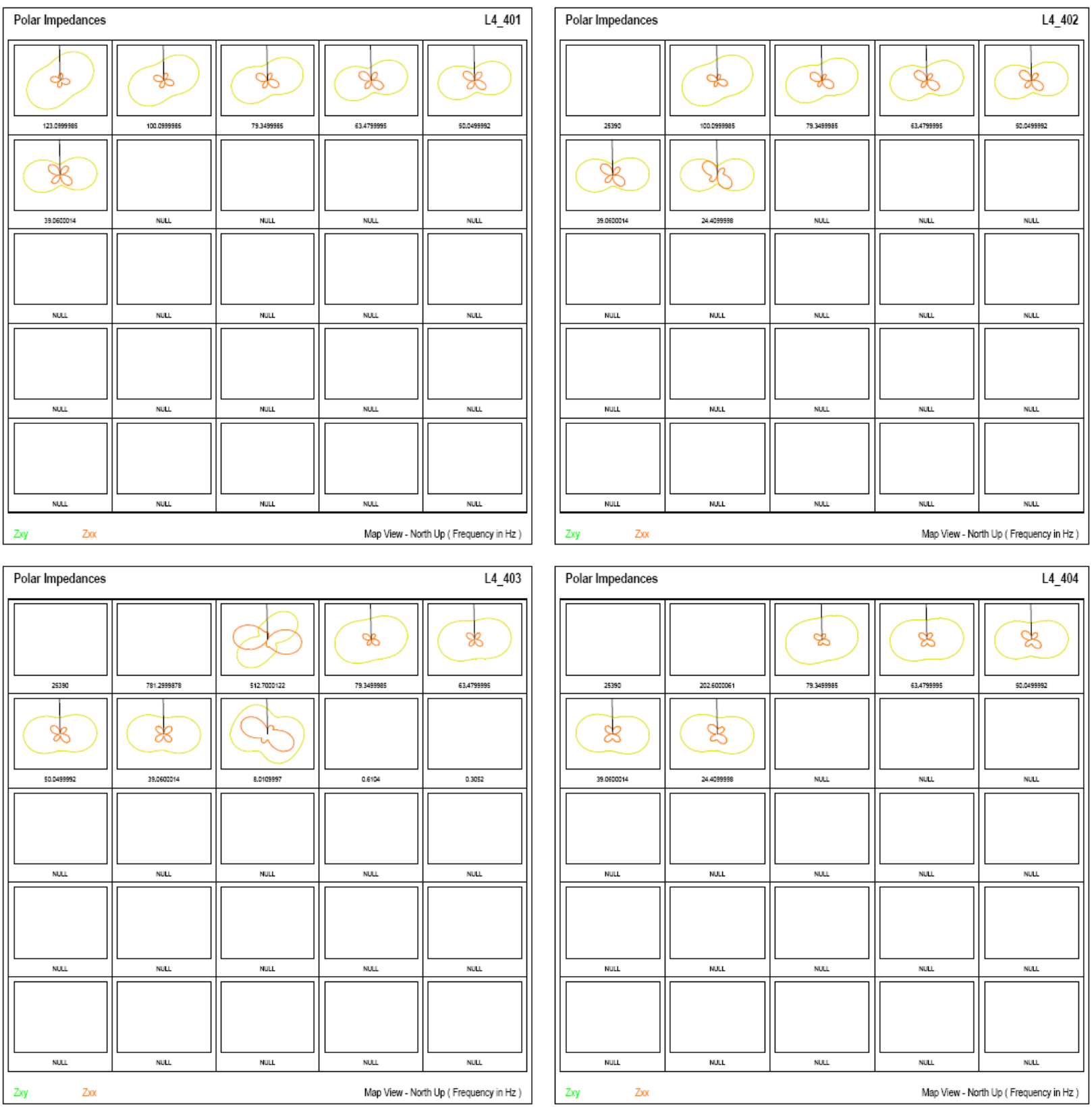

Figure B-137. Polar impedance plots for Line 4, sites 1 to 4. 


\section{U.S. Geological Survey}

Denver Federal Center

Denver, Colorado 80225

MT Data for: L4

Date: 09/18/08
正Geotools

MT Workstation

by

Geotools Corporation

5808 Balcones Dr. Suite 202

Austin, Texas 78731 USA

(512) 454-0679
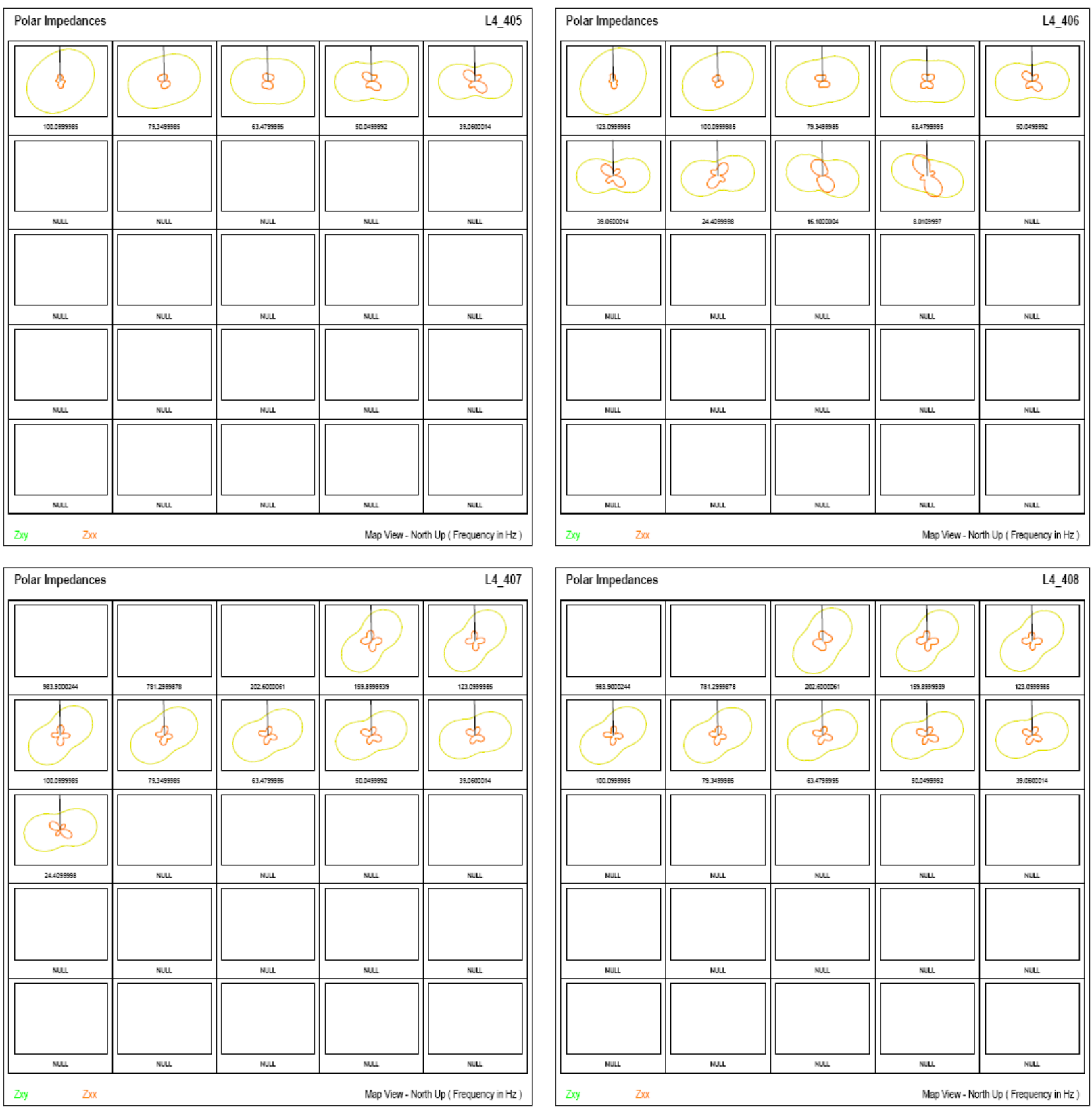

Figure B-138. Polar impedance plots for Line 4, sites 5 to 8 . 


\section{U.S. Geological Survey}

Denver Federal Center

Denver, Colorado 80225

MT Data for: L4

Date: 09/18/08

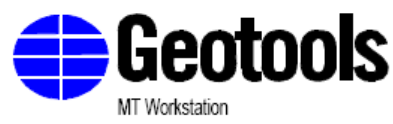

by

Geotools Corporation

5808 Balcones Dr. Suite 202

Austin, Texas 78731 USA

(512) $454-0679$
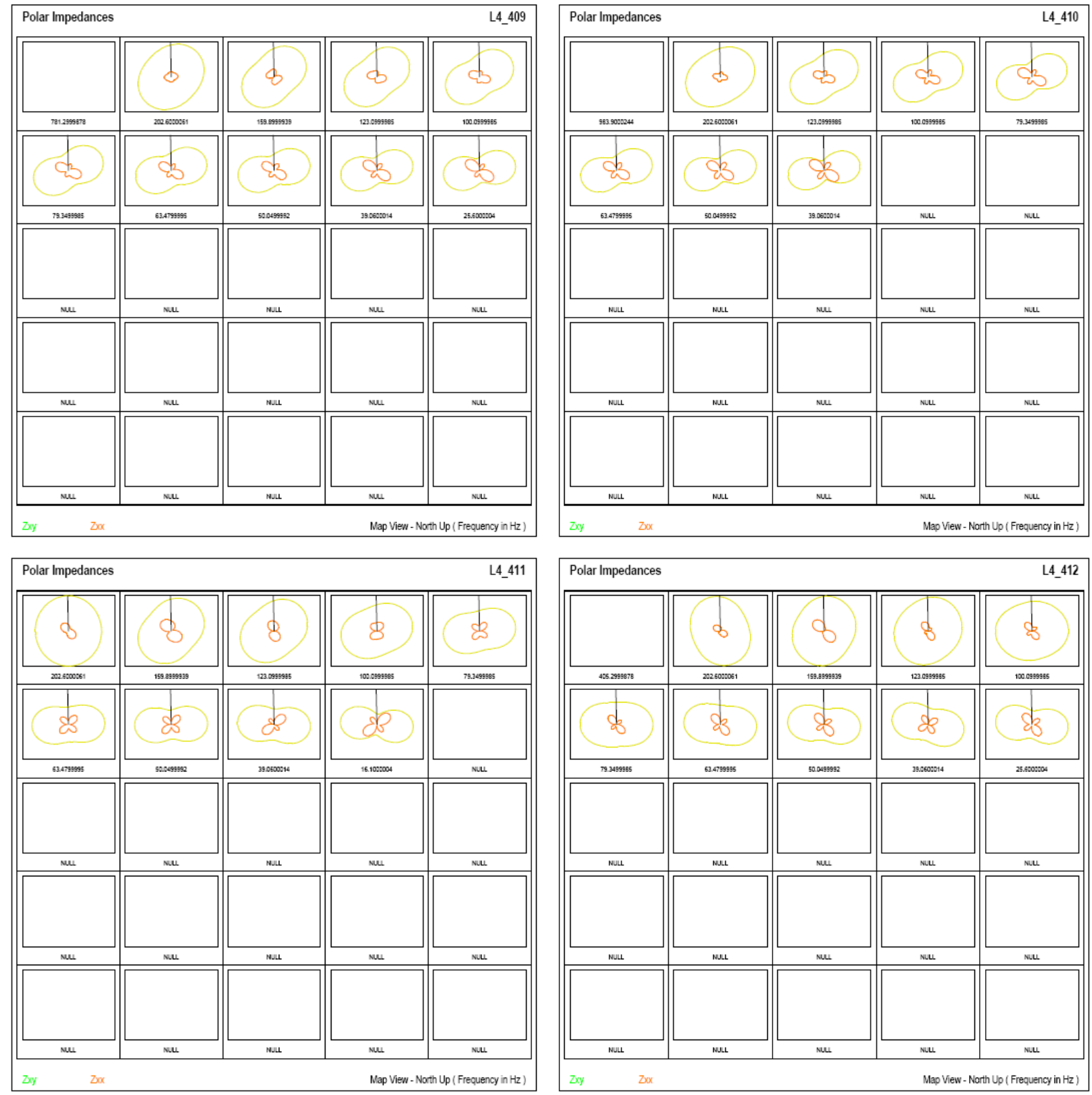

Figure B-139. Polar impedance plots for Line 4, sites 9 to 12. 


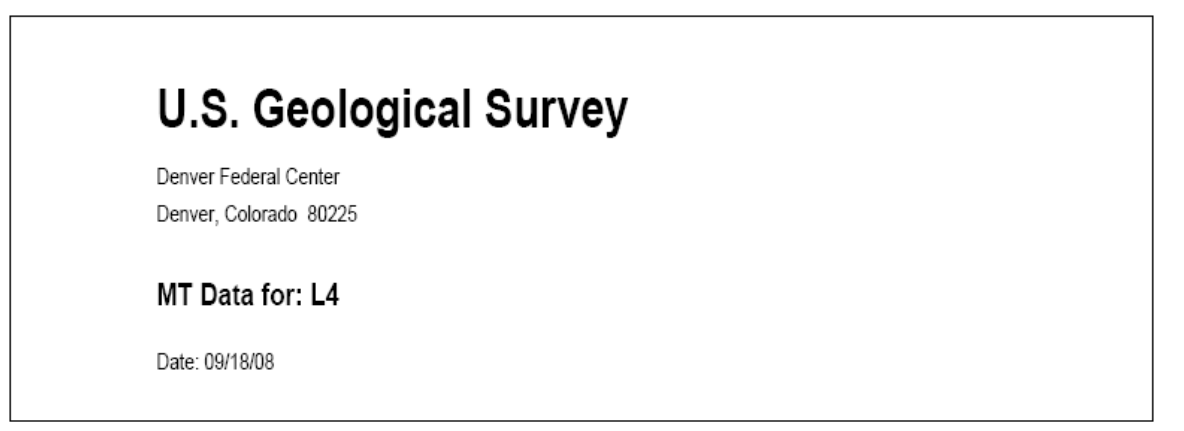

F Geotools by Geotools Corporation 5808 Balcones Dr. Suite 202 Austin, Texas 78731 USA (512) 454-0679
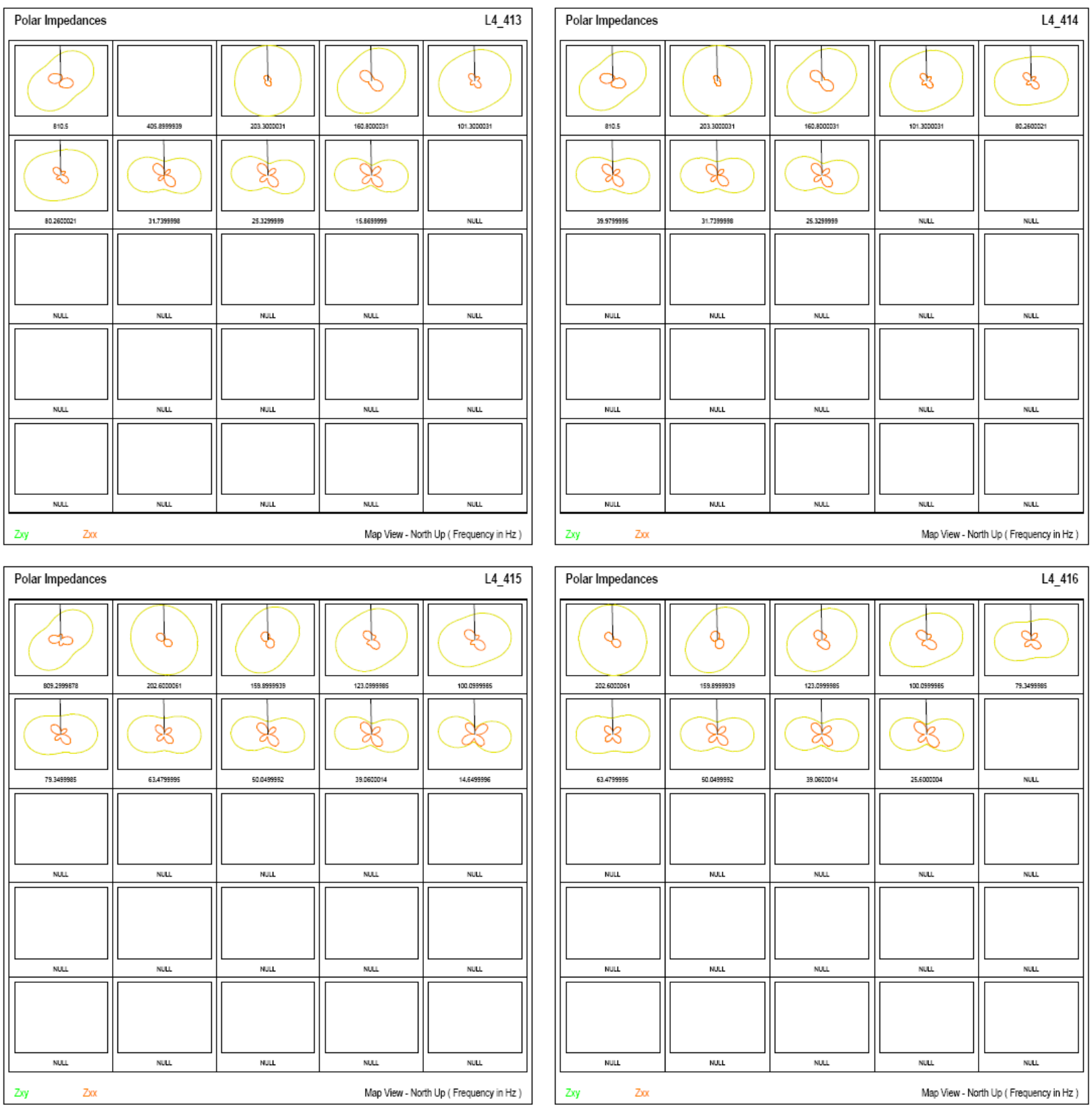

Figure B-140. Polar impedance plots for Line 4, sites 13 to 16. 


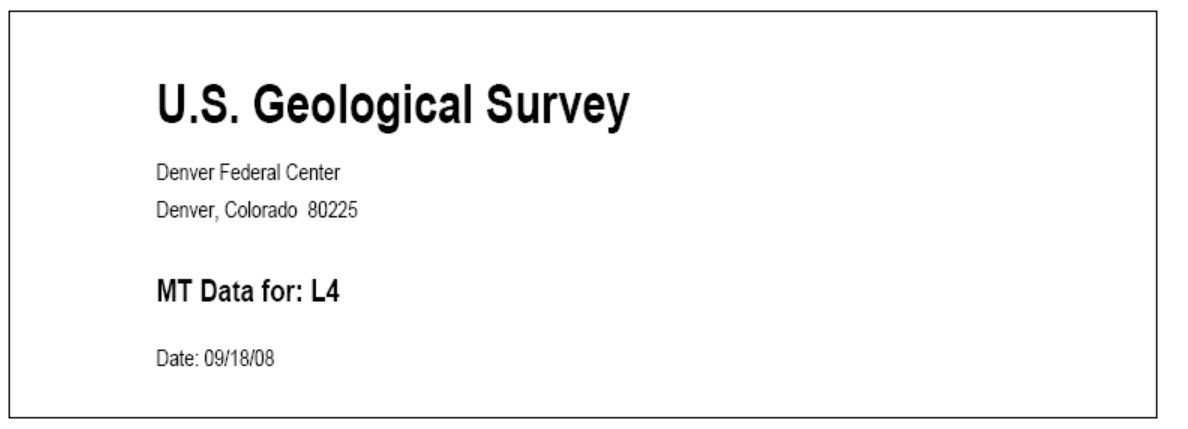

东Geotools

by

Geotools Corporation

5808 Balcones Dr. Suite 202

Austin, Texas 78731 USA

(512) 454-0679
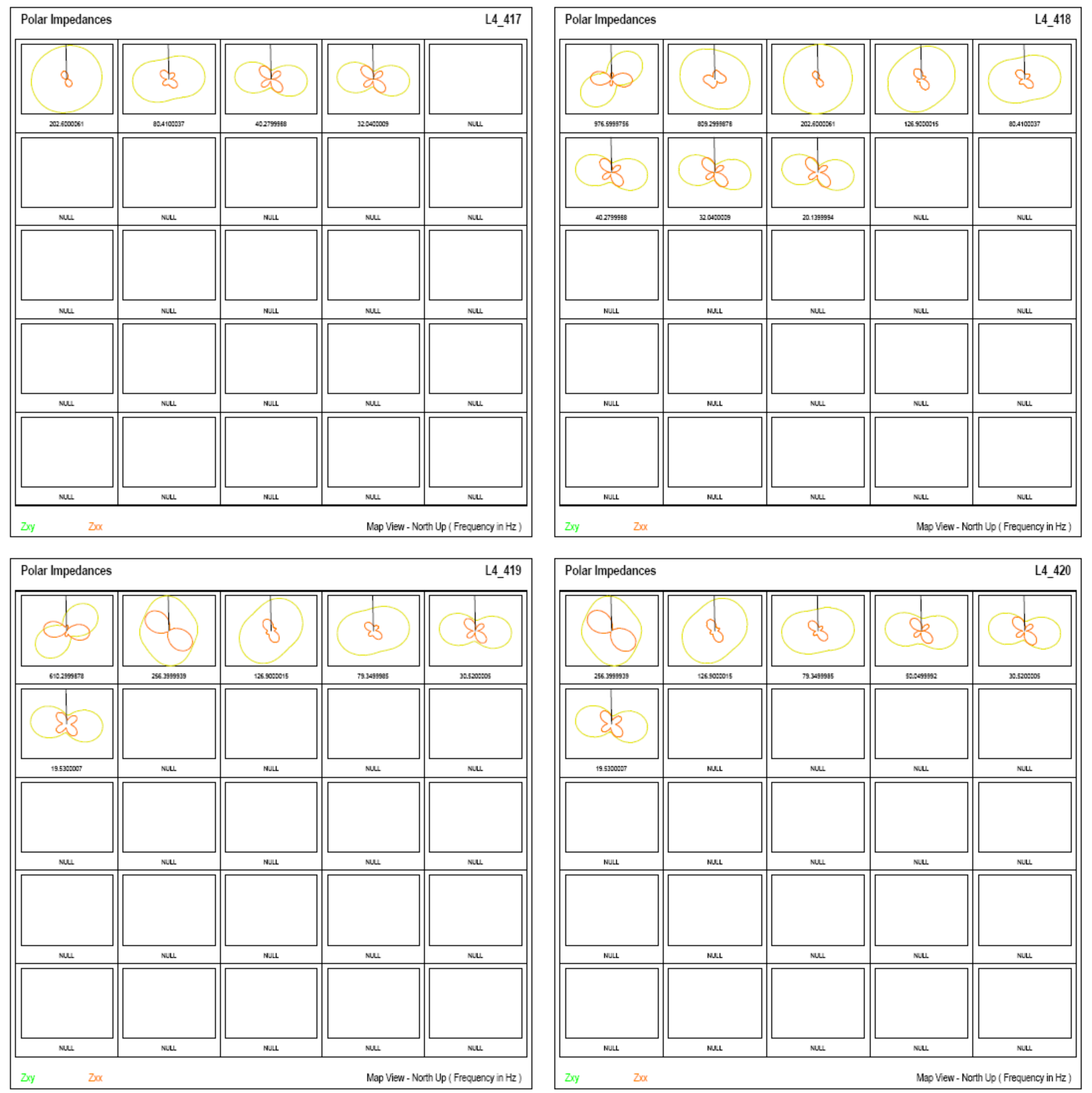

Figure B-141. Polar impedance plots for Line 4, sites 17 to 20. 


\section{U.S. Geological Survey}

Denver Federal Center

Denver, Colorado 80225

MT Data for: L4

FGeotools

MT Workstation

Date: 09/19/08

by

Geotools Corporation

5808 Balcones Dr. Suite 202

Austin, Texas 78731 USA

(512) 454-0679
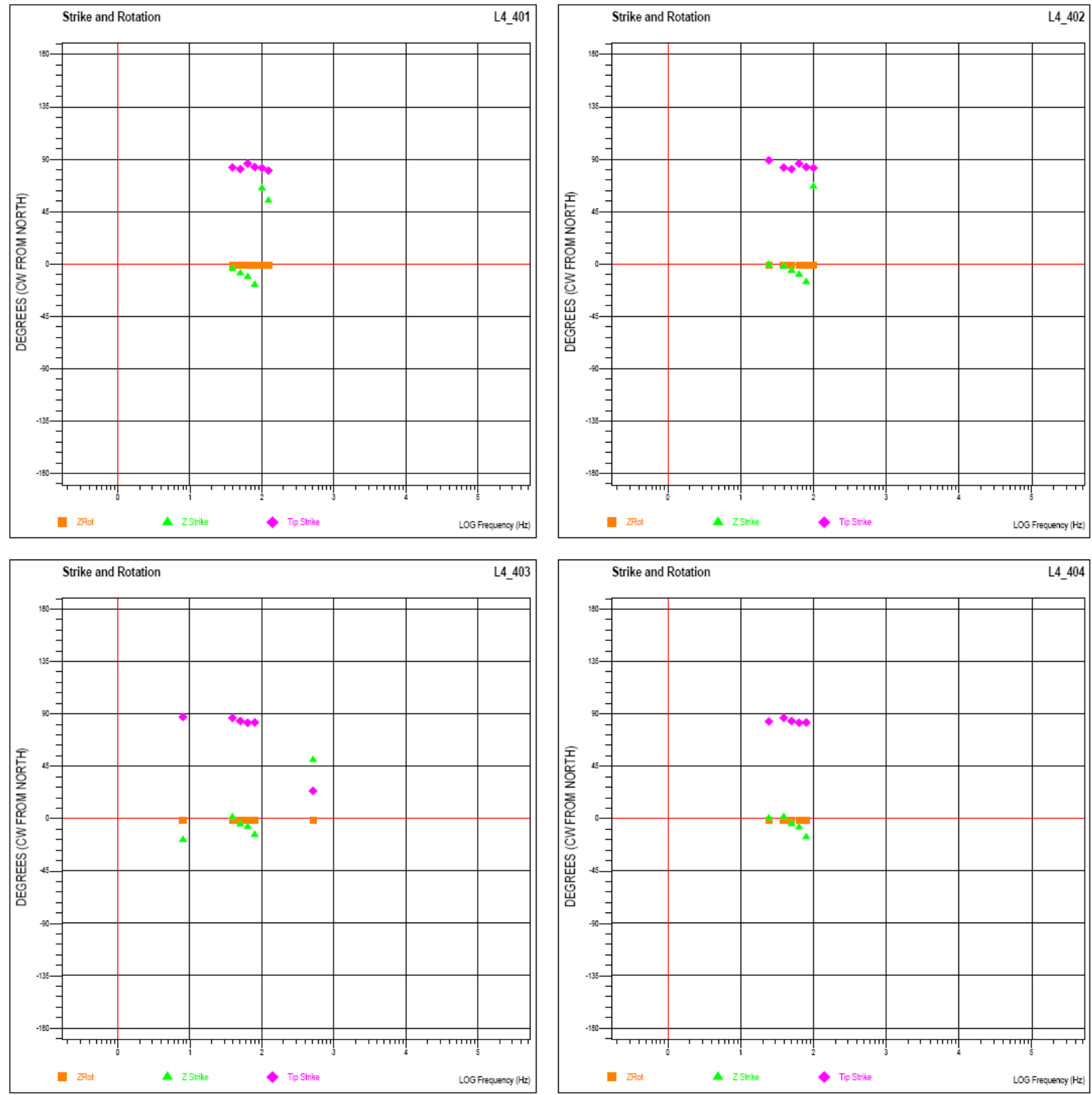

Figure B-142. Impedance strike, rotation, and tipper strike for Line 4, sites 1 to 4. 


\section{U.S. Geological Survey}

Denver Federal Center

Denver, Colorado 80225

MT Data for: L4

FGeotools

MT Workstation

by

Geotools Corporation

5808 Balcones Dr. Suite 202

Date: $09 / 19 / 08$

Austin, Texas 78731 USA

(512) 454-0679
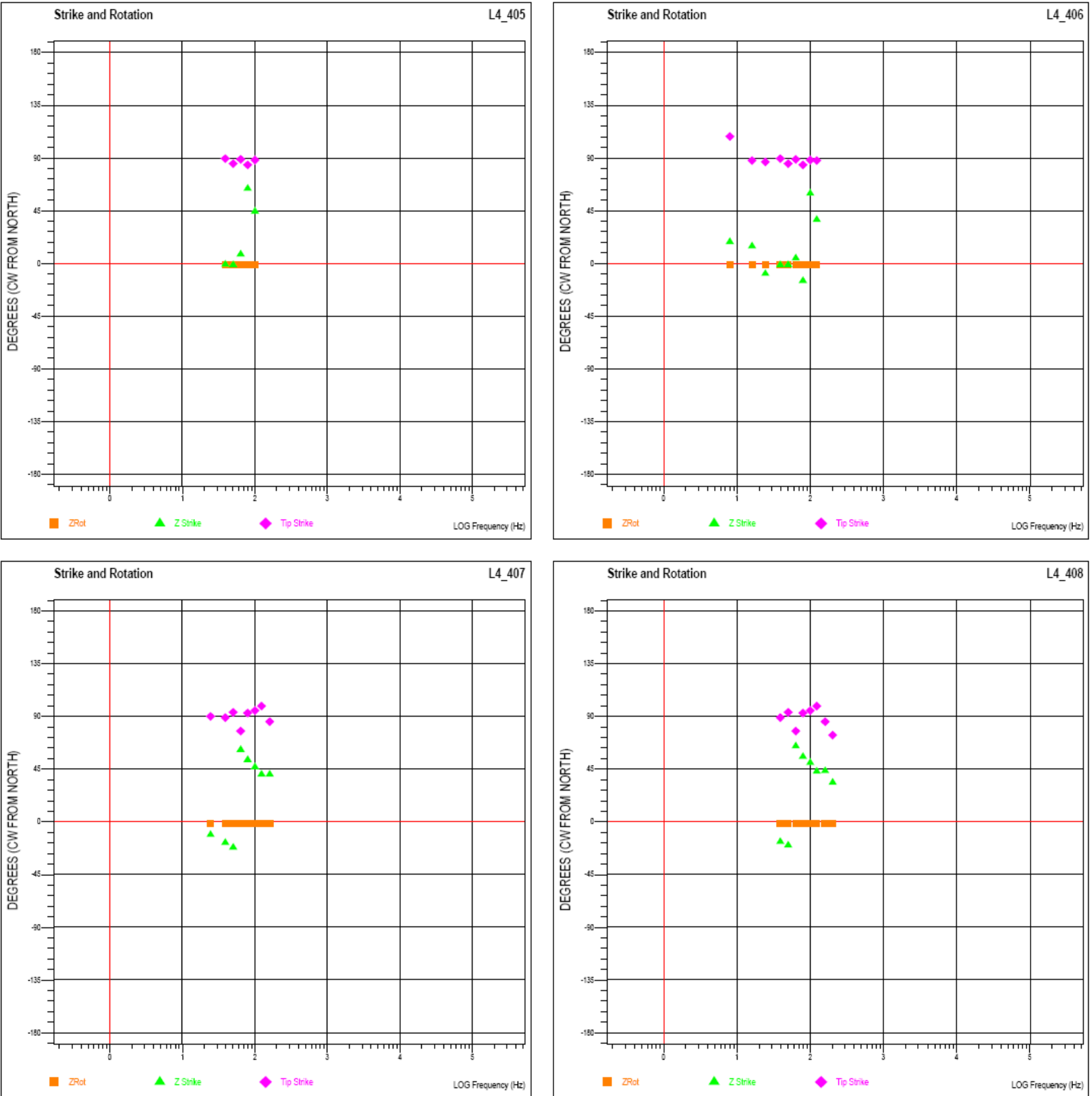

Figure B-143. Impedance strike, rotation, and tipper strike for Line 4, sites 5 to 8 . 


\section{U.S. Geological Survey}

Denver Federal Center

Denver, Colorado 80225

MT Data for: L4

Date: 09/19/08

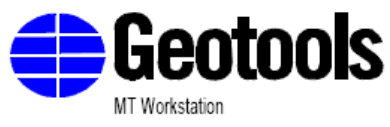

by

Geotools Corporation

5808 Balcones Dr. Suite 202

Austin, Texas 78731 USA

(512) 454-0679
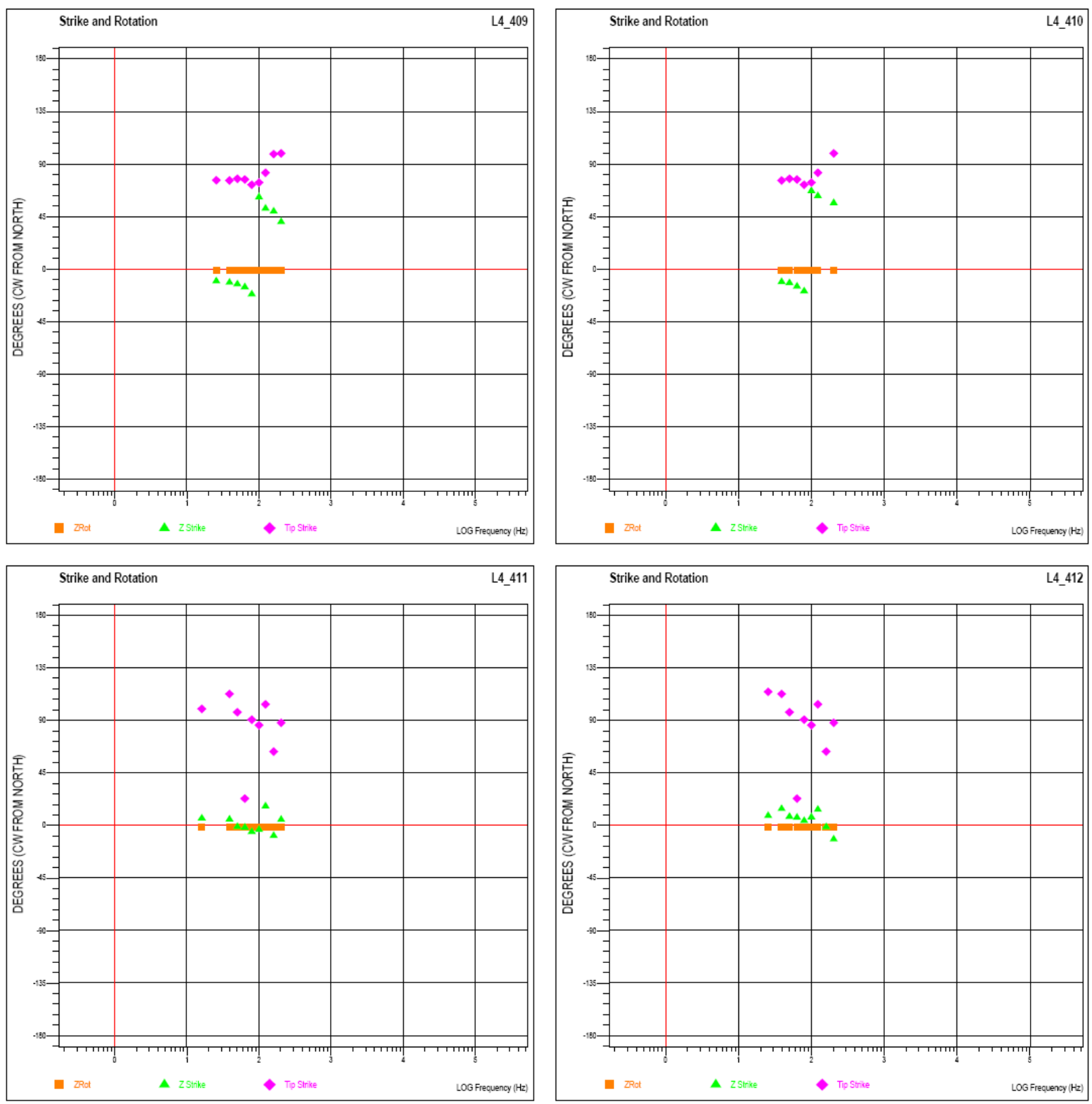

Figure B-144. Impedance strike, rotation, and tipper strike for Line 4, sites 9 to 12 


\section{U.S. Geological Survey}

Denver Federal Center

Denver, Colorado 80225

MT Data for: L4

Date: 09/19/08
FGeotools

MT Workstation

by

Geotools Corporation

5808 Balcones Dr. Suite 202

Austin, Texas 78731 USA

(512) 454-0679
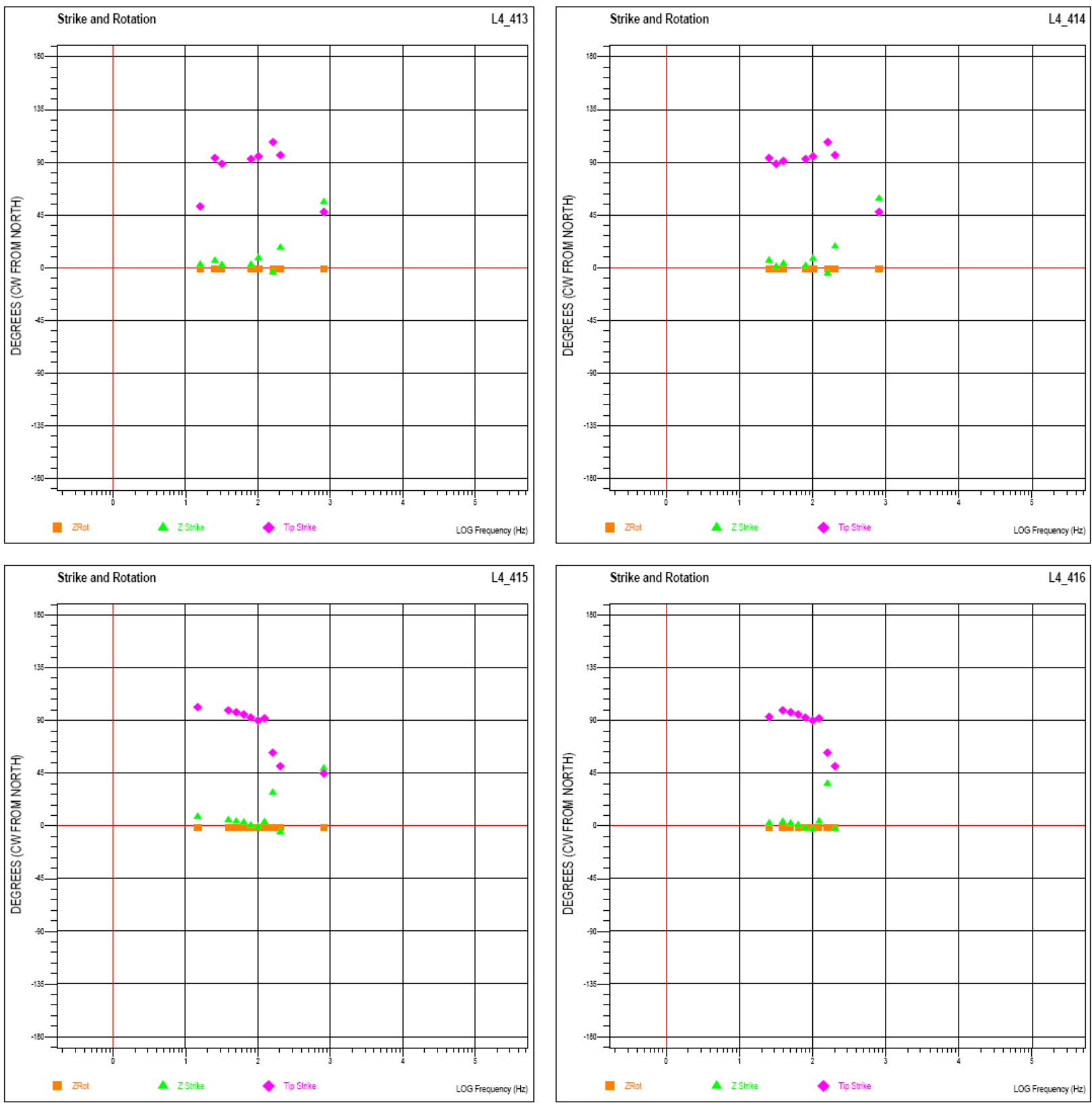

Figure B-145. Impedance strike, rotation, and tipper strike for Line 4, sites 13 to 16 


\section{U.S. Geological Survey}

Denver Federal Center

Denver, Colorado 80225

MT Data for: L4

Date: $09 / 19 / 08$
专Geotools

MT Workstation

by

Geotools Corporation

5808 Balcones Dr. Suite 202

Austin, Texas 78731 USA

(512) 454-0679
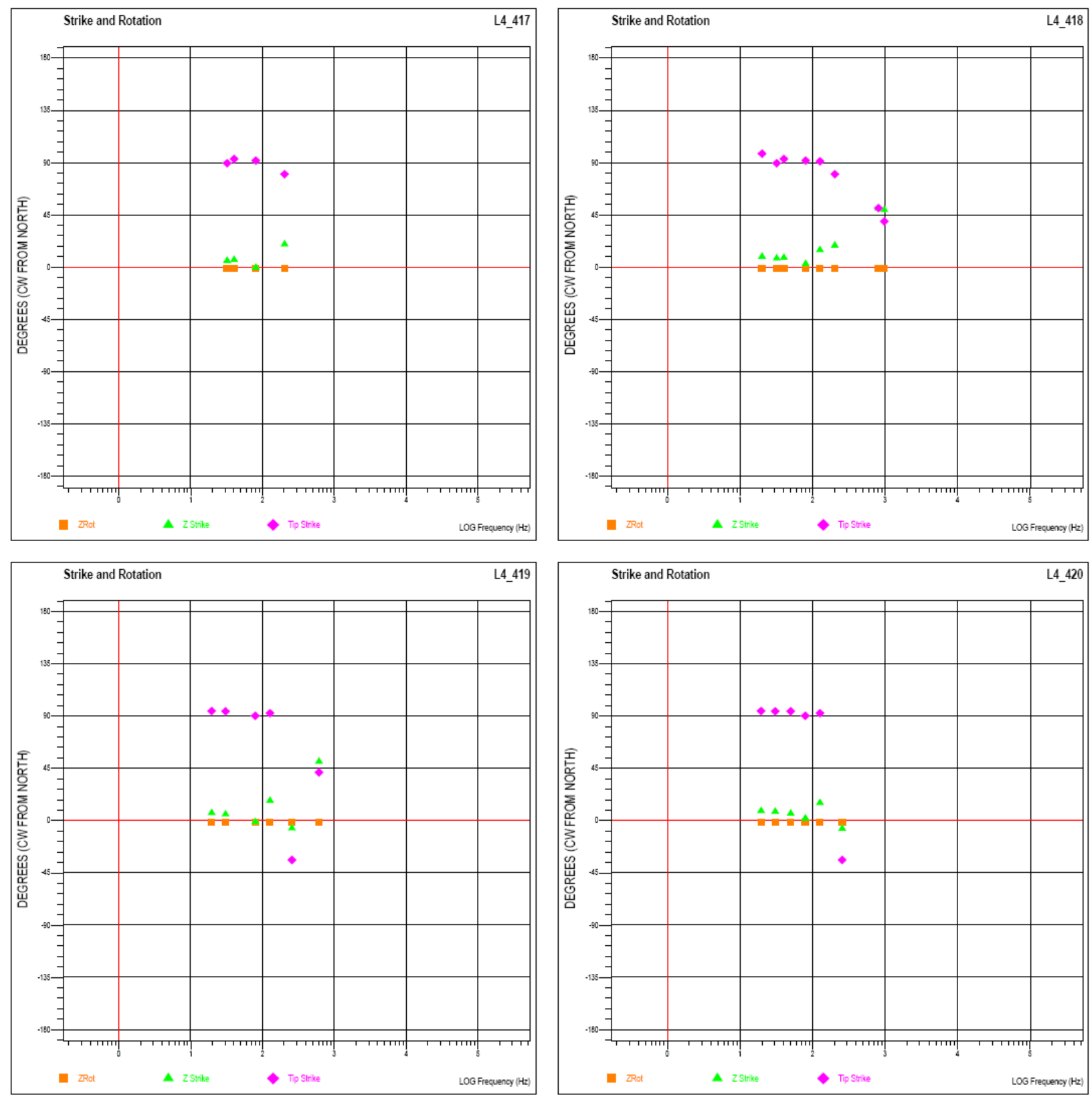

Figure B-146. Impedance strike, rotation, and tipper strike for Line 4, sites 17 to 20. 